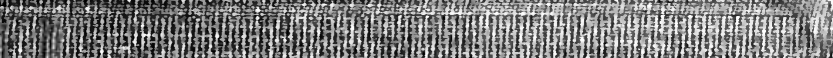
m.m mom $m$ mom

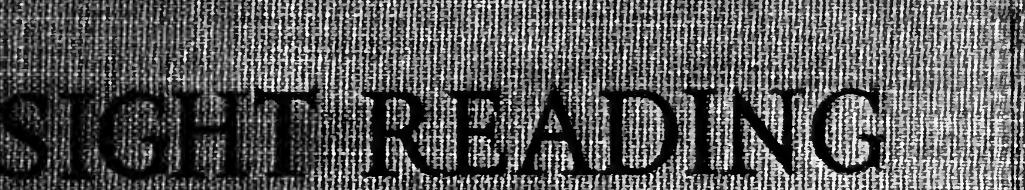

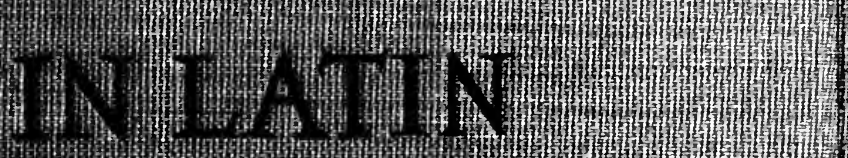
Brop.

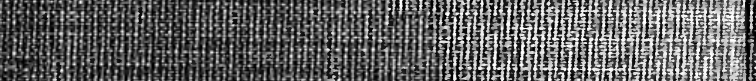
พ 2.

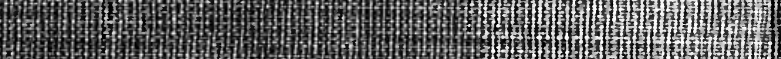

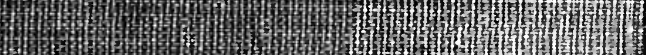

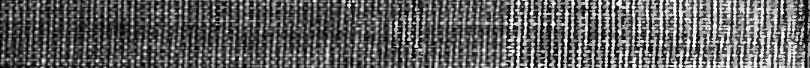
แ m. m. a H.m.m

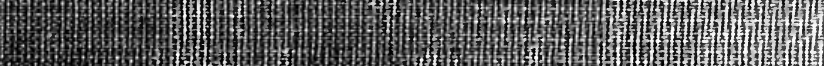

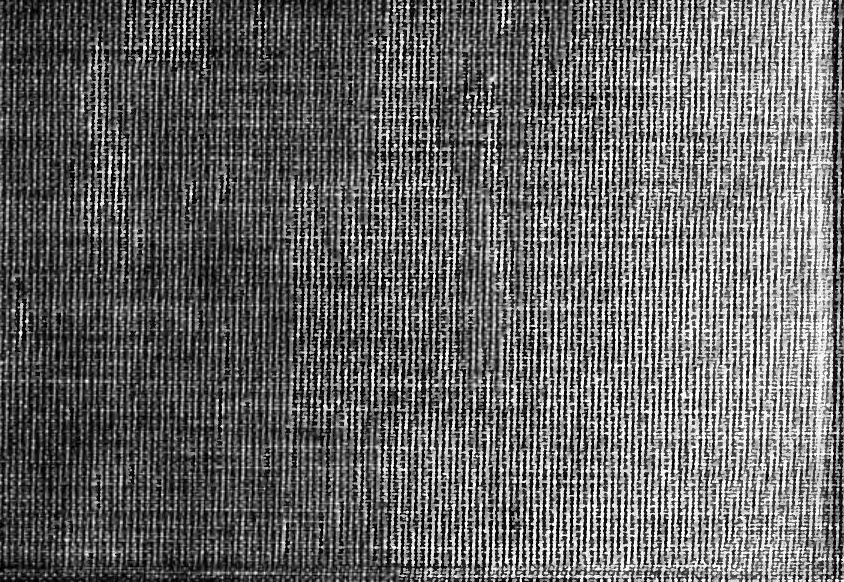




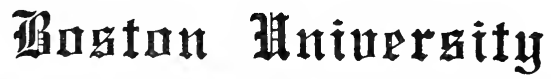 (Tallege af Titheral Arta Tithrary}

The Gift of.C.CI I adóe-Class of'78

Ilecember 19,9 No. 478.7 347 



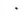




\title{
SIGHT READING IN LATIN FOR THE SECOND YEAR
}

BI

\section{HIRAM H. BICE}

HEAD OF THE DEPARTMENT OF LATIN, DE WITT CLINTON HIGIH SCHOOL NEW YORK CITY

\section{BOSTON UNIVERSITY \\ COLLEE OF LIBERAL ARTS \\ HBRARY}

\author{
GINN AND COMPANY
}

BOSTON $\cdot$ NEW YORK $\cdot$ CHICAGO $\cdot$ LONDON 
COPYRIGHT, I9I3, BY

HIRAM H. PICE

ALL RIGHTS RESERVEL

$5 \cdot 3.7$

The $\mathfrak{A t h e n x u m ~ p r e s s ~}$

GIN AND COMPANY PROPRIITURS - LUSTUN - U.S.A. 


\section{$P A$ \\ F年 \\ PREFACE}

The material for sight reading offered in this book may be used in two ways. Teachers who believe that the passage for translation should be placed before the pupil without preparation, will suggest for his use nothing more than the vocabulary of new words, the notes, and the rule of order accompanying each selection. Those who believe that some preparation should be made will find material suggested at the beginning of each exercise.

The grammatical references are to the common constructions found in the reading prescribed for the second year, and are illustrated in the selection which they introduce. The words which may be made the basis of a drill in inflections, as well as the words in the so-called "prescribed list," also occur in the passage. The latter are to be found in Professor Lodge's List. They include two classes: those which occur for the first time in Books III, IV, and V of the Gallic War, and those which have not occurred often or which may not have been met by the pupil in his reading of Books I and II up to the time when he sees the passage for sight work. The words of the first class are printed in heavy-faced type in the prescribed list, and in the text of the exercises when the lists are discontinued. The meanings should be given by the teacher. The rules relating to the arrangement of the words in the sentence are intended to guide the pupil in observing the grouping of words and their dependence.

The meaning of every word in the passage is given if not found in Lodge's List. Each exercise is complete in itself. Words are therefore repeated whenever necessary, even though they have appeared in previous exercises. 
The book contains rather more matter than is included in Books III and IV of the Gallic War. 'The first thirty exercises are taken from Eutropius, Aulus Gellius, Pliny, Cicero, and Livy. In some cases needed modifications have been made in the Latin, especially in the Livy.

The other exercises are taken from Nepos's lives of Hannibal and Hamilcar, from Casar's Civil War, and from Books III to VII, inclusive, of the Gallic War. In every case the attempt has been made to have the Latin tell a complete episode or story in a series of exercises. Where chapters have been omitted, a résumé of the contents is given in English. 


\section{CONTENTS}

PAGE

Suggestions for Reading at Sight . . . . . . . . . . . . vii

Formation OF WORDS . . . . . . . . . . . . . . . . ix

New Worde . . . . . . . . . . . . . . . . . . . . . . xi

Eutropius . . . . . . . . . . . . . . . . . . . . I

Aulus Gellius

A Boy in the Senate. . . . . . . . . . . . . . . . . . . I2

Advice about the Use of Words . . . . . . . . . . . . . I4

The Gratitude of a Lion . . . . . . . . . . . . . . . . I5

A Famous Horse . . . . . . . . . . . . . . . . . . . . I9

Scipio and the Bribe . . . . . . . . . . . . . . . . . 20

How to make Buildings Fireproof . . . . . . . . . . . . . 2 I

Pliny the Younger

Choosing a Boys' School . . . . . . . . . . . . . . . . 23

A Haunted House . . . . . . . . . . . . . . . . . . 24

Cicero

Two Strange I)reams . . . . . . . . . . . . . . . 28

LivY

Stories of the Life of IIannibal . . . . . . . . . . . . . 29

NEPos

Selections from the Lives:

Hannibal

Hamilcar . . . . . . . . . . . . . . . . 62

C.ESAR

Selections from the Civil War:

Book I . . . . . . . . . . . . . . . . . 66

Book II . . . . . . . . . . . . . . . . . . . . . 73

Selections from the Gallic War:

Book III . . . . . . . . . . . . . . . . . . 82

Book IV . . . . . . . . . . . . . . . . . . . . 102

Book V. . . . . . . . . . . . . . . . . . . IIS

Book VI . . . . . . . . . . . . . . . . . . . I39

Book VII . . . . . . . . . . . . . . . . . . . 143 



\section{SUGGESTIONS FOR READING AT SIGHT}

'To understand a Latin sentence three things must be known: the forms, the relations of the words to one another, and their meanings. Each one of these must be noted and remembered while the sentence is passing under the eye of the reader.

First, then, read each sentence through slowly and thoughtfully, aloud if possible, trying to decide, when each word is reached, what its form is or may be. Do not, when reading the sentence for the first or even for the second time, let the eye jump from place to place, but take each word as it comes. Often the next word will make plain the form of the one before it. Sometimes the form will be perfectly plain when the end of the sentence is reached. Sometimes a word may be in any one of several forms, and the first reading may not show which one it is.

After having read the sentence through in this way one or more times with the forms chiefly in mind, read it once more, trying to see rather how the words are related to one another. Of course it is not possible to avoid doing this to some extent when the sentence is read the first time, but put the attention strongly on this point now. The meanings of many of the words will naturally rise in the mind while this is being done, and will help to show the connection between the parts of the different phrases; for the other readings will have made it clear that the sentence contains a number of groups of words, perhaps prepositional phrases, perhaps nouns limited by an adjective or by a genitive or an ablative, or perhaps clauses of one kind or another. By omitting these mentally in the reading, when they are discovered, the simple, independent statement, which is the real backbone of the sentence, will be found. After this, another reading will usually show the relation which these groups have to one another and to the main statement. 
If the structure is still not clear, the pupil should read the sentence again and again, following the same method, till the light comes. Sometimes the difficulty arises from an ignorance of some principle of syntax or an uncertainty about a form, which must be cleared up by reference to the grammar; or it may come from the hazy memory of the meaning of a word.

After all this the meaning of the whole sentence should be fairly certain, and it should not be a difficult matter to put it into English. If the meaning of a word has escaped the memory, leave a blank for this word in translating the sentence, and often the translation will show what meaning the unknown word must have.

It may seem that this requires much time and is a slow way of getting at the meaning. It is true that for a while this will be so. But the mind must be trained to grasp the meaning of the sentence in the order in which the Roman author developed it in his own mind, and in the order in which he put it in writing. The emphasis in a sentence is lost if the sentence is not read and interpreted in the order in which it is written. This is the only method that leads to accuracy and rapidity in understanding the language; for the Romans were particular about the placing of words, and the study of arrangement, therefore, is of the utmost importance. 


\section{THE FORMATION OF IVORISS}

Many Latin words are made from other Latin words by adding to the stem certain syllables called suffixes.

Those which should be taught to the pupil are given below.

tor. This suffix is added to verb stems or roots to show the doer or the agent of the action, as

imperātor $=$ imperā $($ stem of imperō, command $)+$ tor $=$ one who commands, a commander:

victor $=$ vic $($ root of vincō, conquer $)+$ tor $=$ one who conquers, a conqueror, a victor:

Observe the English equivalents of this suffix.

Occasionally the suffix appears as sor, as in defeennsor, for dēfendtor.

Explain the formation of the following:

mercātor, explōrātor, speculātor, gubernātor, adiūtor.

iō, tiō, tus. These suffixes are addled to verb stems or roots to form nouns which show an act or its result, as

legi $\overline{0}=\operatorname{leg}($ root of leg $\overline{0}$, choose, levy) $+\mathrm{i} \overline{0}=$ the act or result of levying, a legion.

$\bar{o}$ rātio $=\bar{o}$ ra $\bar{a}$ (stem of $\bar{o} r \bar{o}$, plead $)+$ tio $=$ the act or result of pleading, a speech, oration.

conventus $=$ conven $($ con, together, + ven, root of veniō, come $)+$ tus $=$ the act or the result of coming together or assembling, assembly, convention.

Observe the English equivalents of these suffixes.

()ccasionally the suffix tus appears as sus, as in cursus (from currō) for curtus.

Explain the formation of the following:

coniūrātiō, mūnītiō, dēditiō, oppugnātiō, nāvigātiō, obsidiō, dēfēnsiō, occāsus, discessus, mōtus. 
ia, tia, tās, tūs, tūdō. These suffixes are added to the stems of adjectives or nouns to form nouns.

The suffixes ia, tia, tās, tūdō, added to adjective stems, form abstract nouns denoting quality, as

potentia $=$ potent $($ stem of potēns, able, from possum $)+i a=$ ability.

iūstitia = iūsti (weakened stem of iūstus, fair, just) + tia $=$ fairness, justice.

celeritās $=$ celeri $($ stem of celer, swift $)+$ tās $=$ swiftness.

magnitū $\bar{d} \overline{0}=$ magni (weakened stem of magnus, great $)+$ tū $\bar{d}=$ greatness, magnitude.

Observe the English equivalents of these suffixes.

Explain the formation of the following:

memoria, grātia, audācia, dīligentia, sententia, amīcitia, nōbilitās, lībertās, altitūđōo, fortitūdō, multitūdō.

The suffixes ia, tās, tūs, added to noun stems, form nouns denoting a condition or a characteristic, as

mìlitia $=$ mīlit $($ stem of miles, soldier $)+$ ia $=$ military service.

cìvitās $=$ cīvi $($ stem of cìvis, citizen $)+$ tās $=$ citizenshiph.

servitūs $=\operatorname{servi}($ weakened stem of servus, slave $)+$ tūs $=$ slavery , servitzde.

Observe the English equivalents of these suffixes.

Explain the formation of the following:

victōria, auctōritās, tempestās, virtūs, senectūs.

The meanings of words are often changed by prefixing syllables, usually prepositions, which have their original force as adverbs. The most common meanings of the following should be taught to the pupil:

$\mathrm{ab}(\overline{\mathrm{a}}), \mathrm{ad}$, ante, circum, con, dēe dis- $(\mathrm{d} \overline{\mathrm{i}}-\mathrm{-}), \mathrm{ex}(\overline{\mathrm{e}})$, in, in-, inter, ob, per, prae, prō, re(d)-, sub, trāns.

Determine the meaning of the prefix in the following:

absum, āvertō, addūcō, advertō, antepōnō, antecēdō, circumveniō, circumsistō, conveniō, cōnferō, dēiciō, dēcurrō, dispōnō, dīmittō, ēnūntiō, expellō, instō, ìnsequor, incrēdibilis, inermis, intercēdō, interpōnō, oppugnō, occurrō, perdūcō, perspiciō, praestō, praemittō, prōiciō, prōcēdō, respiciō, renovō, redeō, suscipiō, trānseō, trādūcō. 


\section{NEWV WORDS}

The following list includes such words of Caesar, in Professor Lodge's Vocabulary for High School Latin, as do not occur in Books I and II of the Gallic War. With each is given the page and line where it first appears in this book. The meaning should be fixed in mind at the time when the word is first met.

PAge LiNe

PAge Line

Page Line

\begin{tabular}{|c|c|c|c|c|c|c|c|}
\hline $\begin{array}{l}\operatorname{adimō} \\
\text { aedificōo }\end{array}$ & $\begin{array}{r}3^{6} \\
\cdot \quad+\end{array}$ & $\begin{array}{r}18 \\
2\end{array}$ & $\begin{array}{l}\text { cōnsector } \\
\text { cōnstō . }\end{array}$ & $\begin{array}{l}95 \\
46\end{array}$ & $\begin{array}{r}9 \\
\text { I } 6\end{array}$ & $\begin{array}{l}\text { mare } \\
\text { māteria }\end{array}$ & $\begin{array}{r}5 \\
69\end{array}$ \\
\hline estus & 89 & 9 & coorior. & 33 & 5 & mōlēs . & 90 \\
\hline lacer & 99 & It & corōna . & 56 & 2 & mollis & 20 \\
\hline iquot. & $3 t$ & I 3 & cunctor. & $4^{6}$ & I & mōtus & . $\mathrm{II}_{3}$ \\
\hline cora. & 8 I & It & dēdecus & . II 6 & 2 & nauta . & . 124 \\
\hline pellō (3 & $7+$ & 3 & dēfīgō . & . I IO & 17 & nāvigātiō & . 122 \\
\hline tus. & 92 & 3 & dēsiliō. & . 103 & 7 & nāvigō . & . 28 \\
\hline ua & - $3 \mathrm{I}$ & 7 & distō . & . I I I & I & noceō . & . 62 \\
\hline uila & . I I 5 & 9 & distribuō & $\cdot 146$ & I & nōscō & . IIt \\
\hline idus & . IIt & $\delta$ & ēvādō. & . I I & t & obsidiō . & 33 \\
\hline is . & .106 & 9 & ēveniō. & 38 & IO & occāsiō. & 62 \\
\hline$\overline{1}$ & . $\quad 56$ & I 2 & èvocō. & . 67 & I & octingentī & $3^{8}$ \\
\hline . & $\cdot S_{I}$ & 2 & ferreus. & 70 & I 3 & onerārius & . 69 \\
\hline edō . & . 69 & 12 & flūctus . & $9^{I}$ & + & paenitet & .105 \\
\hline llidus & . $\quad 5^{8}$ & 3 & frūstrā . & 86 & 5 & parum. & 69 \\
\hline & . I 27 & 7 & fūnis . & $9^{I}$ & 8 & pecus . & . 4 \\
\hline utēs . & . 92 & 9 & gubernātor & r 72 & 5 & peragō . & . I I $S$ \\
\hline rtāmen & . 32 & 8 & hiems . & . 102 & I & pergō . & - $9^{8}$ \\
\hline us . & 16 & + & humilis. & . 77 & 4 & plānus. & It \\
\hline $\mathrm{m}$ & 57 & 3 & immittó & 19 & 5 & portus. & 68 \\
\hline ssis . & . 62 & 9 & īnsula . & . 62 & IO & praeda & $3 \mathrm{I}$ \\
\hline festim & . $I 45$ & 2 & lac. & . 102 & It & prōnūntiō & . 77 \\
\hline iscend & . $\quad 28$ & 3 & litus. & . II 3 & 8 & prōnus . & . IIO \\
\hline
\end{tabular}


xii

PAgE LINE

PAge LiNe

PAge LiNe

puppis . 9 I $^{2}$ rōstrum . $92+$ ubique . . 694 quamvīs . Iot 3 saeviō. . 927 ūndecim . It4 7

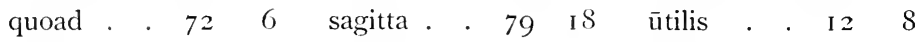

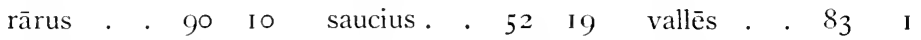
reficiō. . 3t i 5 septem. . $66 \quad 5$ vēlum . 57 It regō . 9I I2 septingentī I26 It ventus . 57 It rēmus . . $\begin{array}{lllllll}92 & 2 & \text { septuāgintā IO8 II vēstīgium . } 77 & 24\end{array}$ renovō. . 43 It tempestās. 7920 rōbur . . 459 tū . . . $14 \quad 5$ 




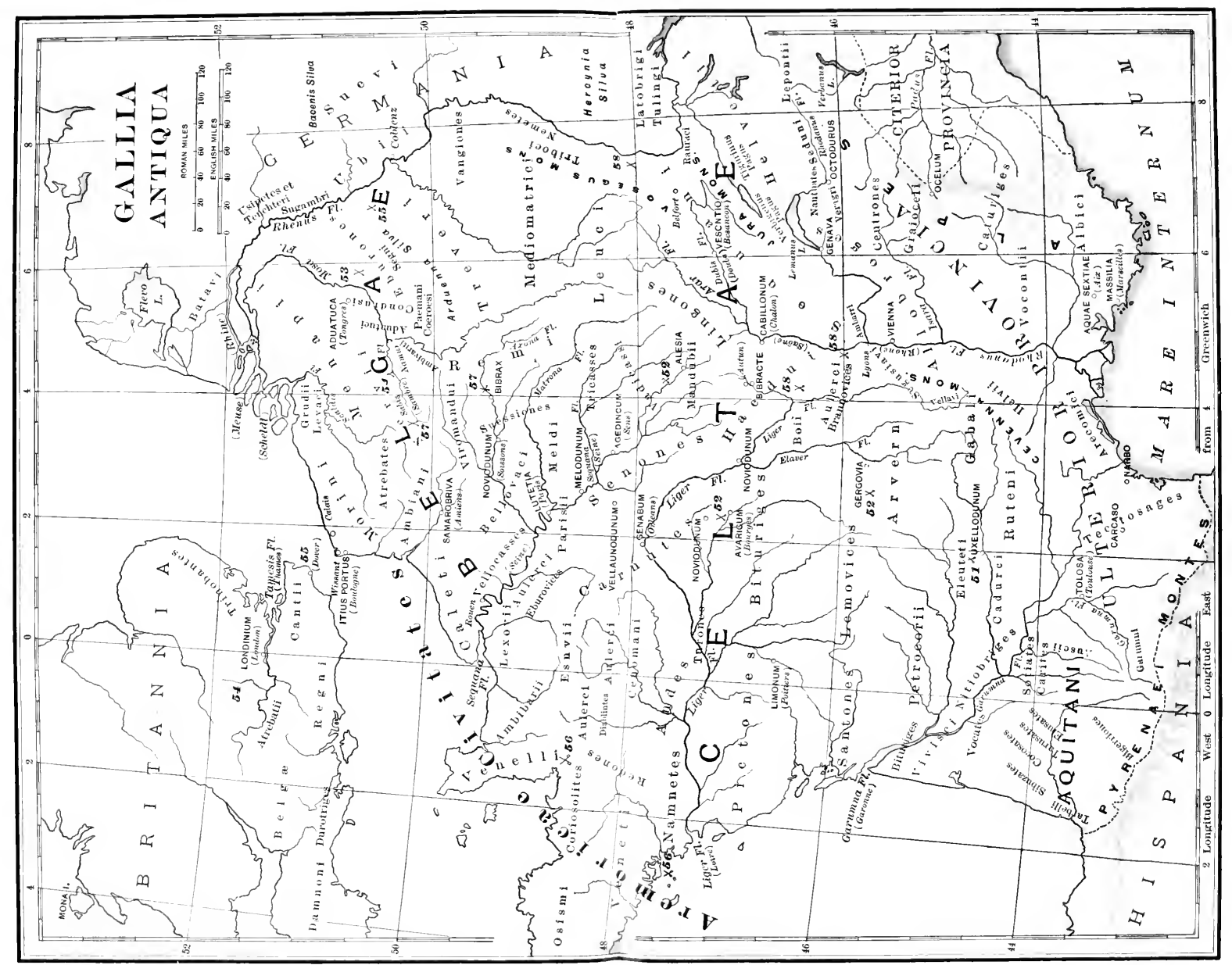




\section{SIGHT READING IN LATIN}

EXERCISE I

Grammar: A. $305 ; 419 ; 423 ; 530 ; 531,2 ; 549$. B. 250, 1 ; 227 ; $230 ; 18_{1} ; 282,2 ; 286,2$. G. 614; 409;393;336;630; 586. H. 396; $489 ; 486 ;+17 ; 589 ; 598$.

Inflection: agō ; mōns: ūnus; quī.

Order of words: the normal order of the sentence is: (1) subject; (2) modifiers of subject; (3) modifiers of verb; (4) verb.

\section{Prescribed list :}

imperium

initium

fîlius

cìvitāte

nōmine

$$
\text { ferē }
$$

ēgit

recēpit

cōnsiliō

propter tum

nātiōnēs

commōtìs

iniūriam vĩcit rēgnì

per

imperāvērunt

HOW ROMULUS, THE FOUNDER OF ROME, HELPED TIIE CITY TO GROIV

Imperium Rōmānum ${ }^{1}$ à Rōmulō initium habet, quī² Reae Silviae, Vestālis virginis, ${ }^{3}$ fìlius fuit. Is, octōdecim annōs ${ }^{4}$ nātus, urbem parvam in Palātīnō ${ }^{5}$ monte cōnstituit. Conditā cīvitāte, quam ${ }^{6}$ ex nōmine suō Rōmam vocāvit, haec ferē ēgit. ${ }^{7}$ Multitūdinem fīnitimōrum in cīvitātem ${ }^{8}$ recēpit, centum ${ }^{9}$ ex seniōribus lēgit, quōrum cōnsiliō omnia ageret, quōs senātōrēs nōmināvit propter senectūtem. ${ }^{10}$ Tum, cum ${ }^{11}$ uxōrēs ipse et populus suus nōn habērent, invītāvit ${ }^{12}$ ad spectāculum ${ }^{13}$ lūdōrum vīcīnas urbis Rōmae nātiōnēs, atque eārum ${ }^{14}$ virginēs rapuit. Commōtis belī̄s propter raptārum ${ }^{15}$ iniūriam, multās vīcīnās nātiōnēs vīcit. Annōo ${ }^{16}$ 
rēgnī trīcēsimō septimō ad deōs trānsissse ${ }^{1 \bar{c}}$ crēditus est. Deinde Rōmae ${ }^{18}$ per quinōos diēs senātōrēs imperāvērunt et hìs rēgnantibus ${ }^{19}$ annus ūnus complētus est. — Eutropıus, I

\section{VOCABULARY}

nāscor, nāscī, nātus, be born

urbs, urbis, f., city'

condō, 3 , didì, ditus, found

vocō, 1, call (vocal)

senex, senis, old

uxor, ōris, f., wife

lūdus, ì, m., game vīcinus, a, um, neighboring (vicinity)

rapiō, 3 , uī, tus, carry off

trīcēsimus, a, um, thirtieth

deus, $\bar{i}, \mathrm{~m} .$, god

crēdō, 3, didī, ditus, beliez'e

deinde, then

quīnī, fiz'e each

\section{NOTES}

${ }^{1}$ Rōmānum: adjective formed from the noun Rōma by the suffix ānus, belonging to. 2 qui : in what respect does this pronoun agree with its antecedent? What word, then, is its antecedent? ${ }^{3}$ Vestālis virginis : a priestess who kept the fire of Vesta. ${ }^{4}$ octōdecim annōs: what do these words tell about nātus? $\quad{ }^{5}$ Palātinō: one of the seven hills of Rome. ${ }^{6}$ quam: relative pronoun. ${ }^{7}$ haec ferē ègit: he did about as follow's. ${ }^{8}$ civitātem : this word and civitāte above refer to Rome. ${ }^{9}$ centum : indeclinable. Senātōrēs below shows that virōs is understood with centum. ${ }^{10}$ senectūtem : derive the meaning of this word by connecting it with the stem of senex. What does senātōrēs really mean? 11 cum: causal. 12 invitāvit: infer the meaning from the English derivative. ${ }^{13}$ spectāculum: see note on invītāvit. 14 eārum : refers to nātiōnēs. 15 raptārum : render by a demonstrative and a relative clause. 16 annō: compare this use of the word with that in annōs above. 17 trānsīsse : trāns + e⿳亠丷. ${ }^{18}$ Rōmae : locative. ${ }^{19}$ rēgnantibus : from rēgnō. Think of rēgnum and reḡo.

This passage contains three examples of the ablative absolute. By what kind of clause should each be translated?

\section{EXERCISE II}

Grammar: A. 282: 286:343:362; 370; 419. B. 169. 1: 233, 3 ; 234; 198: 195: I 87 , I, III ; 227. G. 320; 289; $362 ; 345 ; 347 ; 409$. H. 393; 394: 440, I ; 424; 429: 489 .

Inflection: augēo ; mōs ; minus (compare); hìc. 
Order of words : the arrangement of the words in the sentence represents the order of the development of the thought in the mind of the writer.

\section{Prescribed list :}

$\begin{array}{llll}\text { creātus est } & \text { aliquā } & \text { fīliā } & \text { apud } \\ \text { quidem } & \text { successit } & \text { suscēpit } & \text { suprā } \\ \text { cōnsuētūdine } & \text { vīcit } & \text { contrā } & \text { mare } \\ \text { putābantur } & \text { superāvit } & \text { dīmicāvit } & \text { sextō } \\ \text { mēnsīs } & \text { post } & \text { cìvitātī } & \text { decimō }\end{array}$

HOW NUMA POMPILIUS, TULLLS IIOSTILIUS, AND ANCUS MARCIUS ENLARGED ROME

Posteā Numa Pompilius rēx ${ }^{1}$ creātus est, quī bellum quidem nūllum gessit, sed nōn minus cìvitātī quam² Rōmulus prōfuit. Nam et lēgēs Rōmānīs mōrēsque cōnstituit, quī̄ ${ }^{3}$ cōnsuētūdine proeliōrum sēmibarbarī ${ }^{4}$ putābantur, et annum dēscrīpsit, in decem mēnsīs prius sine aliquā computātiōne cōnfūsum, ${ }^{5}$ et infīnīta Rōmae sacra ac templa cōnstituit. Huic successit ${ }^{6}$ Tullus Hostīlius. Hìc bella gessit, Albānōs vīcit, quī ab urbe Rōmā duodecimō mìliāriō sunt, Vēientīs et Fīdēnātēs bellō superāvit, urbem auxit, adiectō Caeliō ${ }^{7}$ monte. Post hunc Ancus Mārcius, Numae ex fỉliā nepōs, suscēpit imperium. Contrā Latīnōs dìmicāvit, Aventīnum ${ }^{7}$ montem cìvitātī adiēcit et Iāniculum, apud ōstium Tỉberis cìvitātem suprā mare sextō decimō mīliāriō ab urbe Rōmā condidit. - Eutropıus, I

\section{VOCABULARY}

prōsum, prōdesse, prōfuī,-, be helpful lēx, lēgis, f., law (legal)

dēscrībō, 3, scrīpsī, scrīptus, mark out computātiō, ōnis, f., reckoning cōnfundō, 3 , fūđī, fūsus, confuse infïnitus, a, um, without end (infinite) sacra, ōrum, n., rites templum, i, n., temple urbs, urbis, f., city mīliārium, mìliārī, n., milestone (mile) adiciō, 3, iēcī, iectus, add to nepōs, ōtis, m., grandson ōstium, ōstī, n., mouth condō, 3 , didī, ditus, found 


\section{NOTES}

${ }^{1}$ rēx: predicate nominative after creātus est. $\quad{ }^{2}$ quam: take with minus. ${ }^{3}$ quĩ : refers to Rōmănīs. $\quad{ }^{4}$ sēmibarbarī: the prefix sēmi means half, as in "semicircle." For the case, see note on rēx. $\quad{ }^{5}$ confūsum: with what does this participle agree? $\quad{ }^{6}$ huic successit, etc.: him succeeded Tullus Hostilitıs. Huic is emphatic. ${ }^{7}$ Caeliō, Aventinum: two of the seven hiils of Rome.

Think of English words from creātus, lēgēs, cōnstituit, contrā, mare, and other words in the passage.

\section{EXERCISE III}

Grammar: A. $346 ; 370 ; 419 ; 420 ; 423$. B. 201 I I 87 , III ; 227, 2 ; 230. G. 367;368; 347; 409; 410; 393. H. 440, 5; 429; $489, \mathrm{I} ; 486$.

Inflection: ferō; pars; omnis; $\overline{1} \mathrm{dem}$.

Order of words: adjectives and genitives, if emphatic, stand before the nouns which they limit; if not emphatic, after their nouns.

\section{Prescribed list:}

$\begin{array}{llll}\text { deinde } & \text { inīvit } & \text { ipse } & \text { fossās } \\ \text { accēpit } & \text { mūrōs } & \text { successerat } & \text { imperāvit } \\ \text { aedificāvit } & \text { octāyō } & \text { post } & \text { terrārum } \\ \text { ìnstituit } & \text { imperī } & \text { suscēpit } & \text { dēlātīs } \\ \text { memoriam } & \text { occīsus est } & \text { quoque } & \text { fīliae }\end{array}$

TIIE DEEDS OF TARQUINIUS PRISCUS AND SERVIUS TULLIUS, KINGS OF ROME

Deinde rēgnum Tarquinius Prīscus accēpit. Hīc numerum senātơrum ${ }^{1}$ duplicāvit, circum ${ }^{2}$ Rōmae aedificāvit, lūđōs Rōmānōs instituit, quī ad nostram memoriam permanent. ${ }^{3}$ Vicit ${ }^{4}$ idem etiam Sabīnōs et partem agrōrum urbis Rōmae territōriō adiūnxit, ${ }^{5}$ prīmusque triumphāns ${ }^{6}$ urbem inīvit. Mūrōs fēcit et cloācās. Trīcēsimōo octāvō imperī annō occīsus est per Ancī fỉliōs, ${ }^{\bar{T}}$ rēgis eius cui ipse successerat. Post hunc Servius Tullius suscēpit imperium. Hìc quoque Sabīnōs vīcit, montiss ${ }^{8}$ trīs, Quirīnālem, Vìminālem, 
Ēsquilīnum, urbì adiūnxit, fossās circā mūrum dūxit. Prīmus cēnsum omnium imperāvit, quī adhūc ${ }^{9}$ per orbem terrārum incognitus ${ }^{10}$ erat. Sub eō Rōma omnibus in cēnsum dēlātis habuit octōgintā tria mìlia cìvium Rōmānōrum cum iis quī in agrīe erant. Occīsus est quadrāgēsimō quintō imperí annō scelere generī suī Tarquinī, filì eius rēgis cui ipse successerat, et fỉliae, quam Tarquinius habēbat uxōrem. - Eutropıus, I

\section{VOCABULARY}

circus, $\overline{1}, \mathrm{~m}$., the circus lHaximus cēnsus, ūs, m., census

lūdus, $\overline{1}, \mathrm{~m} .$, game

urbs, urbis, f., city'

orbis, is, m., circle, (with terrārum)

territōrium, territōrī, n., domain world

scelus, eris, n., crime

quadrāgēsimus, a, um, fortieth

gener, erī, m., son-in-law

uxor, ōris, f., wife

cloāca, ae, f., sezuer

trīcēsimus, a, um, thirtieth

circā, prep., around, round

\section{NOTES}

${ }^{1}$ senātōrum, duplicāvit: infer the meaning from the English derivatives. 2 circum: where the chariot races were held. ${ }^{3}$ permanent: per + maneō. ${ }^{4}$ vìcit: emphatic. $\quad{ }^{5}$ adiūnxit: ad + iungō. ${ }^{6}$ triumphāns: refers to the entry of a general into Rome after a successful campaign. 'i per filiōs: how does this differ from ā fìliis? $\quad{ }^{8}$ montis : hills. $\quad{ }^{9}$ adhūc: $a d+$ hoc. It refers to time. ${ }^{10}$ incognitus: in + cognōscō.

Determine the emphasis, or lack of it, in the case of each genitive in this passage.

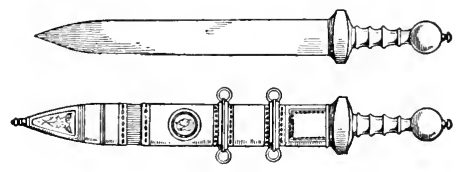

GLADII 


\section{EXERCISE IV}

Grammar: A. 413; 426, 2; 427,3; 530; 531, 1.: 579; 580. B. 222 ;

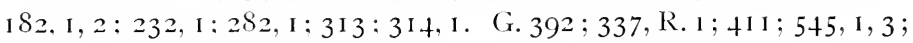
$648: 650$. H. $473.1 ; 418 ; 483 ; 568 ; 641 ; 642 ; 643$.

Inflection: volō; exercitus; septimus; ipse.

Order of words: the demonstrative pronouns regularly precede the nouns which they modify.

Prescribed list:

$\begin{array}{llll}\text { ultimus } & \text { quoque } & \text { ducentīs } & \text { alter } \\ \text { pācem } & \text { vīgintī } & \text { quadrāgintā } & \text { potestātem } \\ \text { posteā } & \text { līberīs } & \text { hinc } & \text { redderentur } \\ \text { octāvō } & \text { fūgit } & \text { coepērunt } & \text { scīrent } \\ \text { decimō } & \text { ita } & \text { creārī } & \end{array}$

TIE LAST KING IS EXPELLED FROM ROME AND CONSULS ARE ELECTEI

Lūcius Tarquinius Superbus, septimus atque ultimus rēgum, Volscōs, quae gēns nōn longēe ab urbe est, vīcit, cum ${ }^{1}$ Tuscīs pācem fēcit, et templum Iovī ${ }^{2}$ in Capitōliō aedificāvit. Posteā Ardeam oppugnāns, cìvitātem in octāvō decimō miliāriō ab urbe positam, scelere fîlī suĩ imperium perdidit. Propter quod scelus Brūtus, parēns Tarquinī, populum commōovit. Exercitus quoque, quī civitātem Ardeam cum ipsō rēge oppugnābat, eum reliquit ; et rēx ad urbem veniēns exclūsus est, ${ }^{3}$ cumque imperāsset ${ }^{4}$ annōs vīgintī quīnque, cum uxōre et lỉberīs suīs fūgit. Ita Rōmae ${ }^{5}$ rēgnātum est $^{6}$ per septem rēgès annīs ducentīs quadrāgintā tribus. Hinc cōnsulēs coepērunt prō ūnō rēge duo ${ }^{7}$ hāc causā creārī, ut, sī ūnus malus ${ }^{8}$ esse voluisset, alter habēns potestātem similem eum coercēret. Et placuit ${ }^{9}$ nē imperium longius quam annum habērent, nē per diūturnitātem potestātis inssolentiōrēs ${ }^{10}$ redderentur, sed cīvīlēs semper essent, quî sể ${ }^{11}$ post annum scịrent futūrōs esse privātōs. 


\section{VOCABULARY}

gēns, gentis, f., tribe

urbs, urbis, f., city

mīliārium, mīliārī, n., milestone

scelus, eris, n., crime

perdō, 3, didī, ditus, lose

parēns, entis, m.,f., relatiz'e

uxor, ōris, f., wife malus, a, um, bad

similis, e, like (similar)

coercēo, 2, uī, itus, check

placeō, 2, uī, itum, please

diūturnitās, ātis, f., long duration civilis, e, cirill, of the citizens

semper, always

\section{NOTES}

1 cum: what part of speech? Consider the case of Tuscis. ${ }^{2}$ Iovi: dative case of Iuppiter. $\quad{ }^{3}$ exclūsus est: from exclūdō. Infer the meaning from the English derivative. 4 imperāsset: for imperāvisset; the $\mathrm{v}$ is dropped and the two vowels are contracted. ${ }^{5}$ Rōmae: what question about rēgnātum est does this word seem to answer? ${ }^{6}$ rēgnātum est: the ending um shows that the subject is neuter, it. Such impersonal forms are often used, where the English idiom employs the personal construction; the goz'enment was carried on. ${ }^{7}$ duo: take with cōnsulēs. ${ }^{8}$ malus: predicate adjective. $\quad{ }^{9}$ placuit: impersonal. $\quad{ }^{19}$ insolentiōrēs : first determine the positive; then infer the meaning from the English derivative. $11 \mathrm{se}$ : to what word does it refer? For the case, note the ending of futūrōs.

Think of English words from pācem, aedificāvit, positam, ūnus.

\section{EXERCISE V}

Grammar: A. 4I9: 423, I : 530; 531, I ; 549; 563. В. $227: 230$; $2 S_{2}, \mathrm{I} ; 286,2: 295,4$. G. $409 ; 3 S_{5} ; 5+5, \mathrm{I}, 3 ; 586 ; 546$. H. $4 S_{9}$; $4{ }_{3} ; 568 ; 598 ; 565$.

Inflection: possum; auxilium ; multus (compare); suī.

Order of words: an appositive usually follows the word to which it belongs.

\section{Prescribed list:}

$\begin{array}{llll}\text { maximē } & \text { rēgnum } & \text { quoque } & \text { tunc } \\ \text { autem } & \text { restitūi } & \text { iterum } & \text { suscip̄ì } \\ \text { quisquam } & \text { dīmicāvit } & \text { reciperētur } & \text { sē contulit } \\ \text { manēret } & \text { occīdērunt } & \text { paene } & \text { longē } \\ \text { tamen } & \text { revertērunt } & \text { vērum } & \end{array}$


THE FIRST CONSULS ARE ELECTED AND BEGIN WAR WITH TARQUINIUS

Fuērunt ${ }^{1}$ annō prīmō expuls̄̄s² rēgibus cōnsulēs Lūcius Iūnius Brūtus, quī maximē ègerat ut Tarquinius pellerētur, et 'Tarquinius Collātinus. Placuit ${ }^{3}$ autem nè quisquam in urbe manēret quī Tarquinius ${ }^{4}$ vocārētur. Ergōo Collātīnus ex urbe migrāvit et locō ipsīus factus est Valerius Pūblicola cōnsul. ${ }^{5}$ Commōvit tamen bellum urbì Rōmae rēx Tarquinius, quī erat expulsus, et collēctīs multīs gentibus, ut in rēgnum posset restituī, ${ }^{6}$ dīmicāvit. In prīmā pugnā Brūtus cōnsul et Arūns, 'Tarquinì fìlius, in vicem ${ }^{7}$ sē occìdèrunt. Rōmānì tamen ex cā pugnā victōrès revertērunt. Secundō quoque annō iterum 'Tarquinius, ut reciperētur in rēgnum, bellum Rōmānīs ${ }^{8}$ intulit, auxilium ${ }^{9}$ eĩ ferente Porsenā, Tusciae rēge, et Rōmam paene cēpit. Vèrum tunc quoque victus est. Tertiō annō post rēgēs expulsōs Tarquinius, cum suscipi nōn posset in rēgnum, ${ }^{10}$ neque eì Porsena, quī pācem cum Rōmānīs fēcerat, auxilium ferret, Tusculum sē contulit, quae cìvitās nōn longēe ab urbe est, atque ibi per quattuordecim annōs prīvātus ${ }^{11}$ cum uxōre vīxit.

\section{Eutropius, I}

\section{VOCABULARY}

placeō, 2, uī, itum, please

urbs, urbis, f., city

vocō, 1 , call

ergō, therefore

migrō, I, depart (migrate) colligō, 3. lēgī, lēctus, grather together

gēns, gentis, f., tribe

uxor, öris, f., wife

vìvō, 3, vīxī, vīctum, liz'e

\section{NOTES}

1 fuērunt: with intransitive verbs two nominatives may be expected, one subject, one predicate. 2 expulsis : in what ways may this construction be translated? Which is best here? $\quad{ }^{3}$ placuit: impersonal. $\quad{ }^{4}$ Tarquinius : predicate nominative after vocārētur. $\quad{ }^{5}$ cōnsul: see note on Tarquinius. ${ }^{6}$ ut ... restituĩ : this states the purpose of dimicāvit. $\quad{ }^{7}$ in vicem: in turn. ${ }^{8}$ Rōmānīs: in what case? Consider the verb. ${ }^{9}$ auxilium: object of ferente. ${ }^{10}$ cum ... rēgnum: this answers the question "why" about sē contulit. $\quad{ }^{11}$ prīvātus: from prīvō; in retirement. 


\section{EXERCISE VI}

Grammar: A. 291, b; 305; 362:370; 423, I. B. 240, 2: 250,1 : I $S 7$, I, III ; 230. G. 6I4; 345; 347; 393. H. 498; 396; 424; $429 ; 486$.

Inflection: ē̄ ; nōmen; alter ; is.

Order of words: adverbs are regularly placed before the words which they modify.

\section{Prescribed list:}

$\begin{array}{llll}\text { posteā } & \text { autem } & \text { obsidibus } & \text { poscere } \\ \text { imperāvit } & \text { ferē } & \text { aggressus } & \text { adversum } \\ \text { deinde } & \text { intulit } & \text { rediēns } & \text { fūgit } \\ \text { gravissima } & \text { nē ... quidem } & \text { coepit } & \text { vacuam } \\ \text { prōcessit } & \text { cognitum erat } & & \end{array}$

CESAR CONQUERS GAUL, VISITS BRITAIN, AND RETURNS TO ROME WITII HIS ARMI

Annō urbis conditae ${ }^{1}$ sescentēsimō nōnāgēsimō tertiō Gāius Iūlius Caesar, quī posteā imperāvit, cum Lūciō Bibulō cōnsul² factus est. Dēcrēta est ${ }^{3}$ eî Gallia et İllyricum cum legiōnibus decem. Is prīmō vìcit Helvētiōs, quī nunc Sēquanī ${ }^{4}$ appellantur, deinde per bella gravissima ūsque ad Ōceanum Britannicum prōcessit. Domuit ${ }^{5}$ autem annīs novem ferē omnem Galliam, quae inter Alpīs, flümen

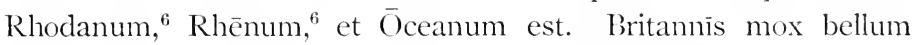
intulit, quibus ante eum nē nōmen quidem Rōmānōrum cognitum erat, et eōs ${ }^{7}$ quoque victōs ${ }^{8}$ obsidibus ${ }^{9}$ acceptīs stīpendiāriōs fēcit. Germānōs trāns Rhēnum aggressus immānissimīs proelīs vīcit. Caesar rediēns ex Galliā victor coepit poscere alterum cōnsulātum, et adversum patriam cum exercitū vènit. Cōnsulēs cum P’ompēiō senātusque omnis atque üniversa ${ }^{10}$ nōbilitās ex urbe fūgit ${ }^{11}$ et in Graeciam trānsiit. Ibi, Pompēiō duce, senātus contrā Caesarem bellum parāvit. Caesar autem vacuam urbem ingressus dictātōrem sē fēcit. - Eutropius, VI 


\section{VOCABULARY}

urbs, urbis, f., city'

condō, 3, didi, ditus, found

sescentēsimus, a, um, six hun-

drectlll

nōnāgēsimus, a, um, ninetieth

dēcernō, 3, crēvī, crētus, decree

ùsque, all the way, ez'en

domō, I, uī, itus, subdue mox, soon

stīpendiārius, a, um, tributary (stipend)

immānis, e, hugse, great

cōnsulātus, ūs, m., consulship

patria, ae, f., native land or city ingredior, gredī, gressus, enter dictātor, ōris, m., dictator. .

\section{NOTES}

1 conditae: translate as a noun with after. $\quad 2$ cōnsul: predicate noun used with factus est. 3 dēcrēta est: agrees with the nearer subject. ${ }^{4}$ Sēquani: predicate noun. 5 domuit: note the emphatic position. See dēcrēta est above. ${ }^{6}$ Rhodanum, Rhēnum: Rhone, Rhine. ${ }^{7}$ eōs, stīpendiāriōs: which of these is the direct object of fēcit, and which the predicate accusative? $\quad{ }^{8}$ victōs: translate by a clause. ${ }^{9}$ obsidibus: what construction does this illustrate, and what is the best way to translate it? 19 universa: infer the meaning from the synonym omnis, and think of an English derivative. 11 fügit: see note on dēcrēta est.

\section{EXERCISE VII}

Grammar: A. 4 I 2 ; 456:530; 53 I, I ; 579: 5So. B. 220, I ; 328, I ; 282, I: 3І 3: 3I 4. G. 399: 423, I, 2; 545, I, 3; 648; 650. H. 473, 3; $607: 568 ; 642 ; 643$.

Inflection: nölō; caput: maior ; ille.

Order of words: words depending on a noun accompanied by a modifier are often put between the noun and the modifier.

Prescribed list:

$\begin{array}{llll}\text { fortissimōs } & \text { tamen } & \text { deinde } & \text { occīdit } \\ \text { superāvit } & \text { nocte } & \text { apud } & \text { caput } \\ \text { inde } & \text { nec } & \text { utrimque } & \text { cōnspectō } \\ \text { adversum } & \text { scīre } & \text { contrā } & \text { lacrimās } \\ \text { ēvāsit } & \text { tantum } & & \end{array}$


POMPEY'S LONG CONFLICT WITH CESAR, FOLLOWED BY HIS DEFEAT ANI DEATH

In Hispāniā ${ }^{1}$ Caesar exercitūs Pompēi validissimōs et fortissimōs cum tribus ducibus superāvit. Inde in Graeciam trānsiit et adversum $^{2}$ Pompēium dìmicāvit. Prīmō proeliō victus est et fugātus, ēvāsit tamen quia nocte ${ }^{3}$ Pompēius sequī nōluit, dīxitque Caesar nec Pompēium scìre ${ }^{4}$ vincere et illō $\operatorname{tantum}^{5}$ diē $\operatorname{sé}^{6}$ potuisse superārī. Deinde in Thessaliā apud Palaepharsālum prōductīs utrimque ingentibus cōpiīs dīmicầērunt. Numquam adhūc cōpiae Rōmānae in ūnum ${ }^{8}$ neque maiōrēs neque meliōribus ducibus convēnerant, tōtum terrārum orbem ${ }^{9}$ facile subāctūrae sī contrā barbarōs dūcerentur. Pugnātum est ${ }^{10}$ ingentī contentiōne, ${ }^{11}$ victusque est ad postrēmum Pompēius, quī Alexandriam petiit, ut à rēge Aegyptī acciperet auxilia. ${ }^{12}$ Qui1 ${ }^{13}$ fortūnam magis quam amīitiam secūtus occīdit Pompēium, caput eius ad Caesarem mìsit. Quō cōnspectō Caesar etiam lacrimās fūdisse dīcitur, tantī virī intuēns caput et generī quondam suī. - Eutropius, VI

\section{VOCABULARY}

validus, a, um, strong (valid)

fugō, I, put to flight

ingēns, ingentis, luuge

numquam, newer

adhūc, thus far

orbis, is, m., circle (orb) subigō, 3, ègī, àctus, subdue contentiō, ōnis, f., conflict funđō, 3 , fū đì, fūsus, shç intueor, 2, tuitus or tūtus, look upon gener, erī, m., son-in-law quondam, once

\section{NOTES}

${ }^{1}$ Hispāniā: Stain. ${ }^{2}$ adversum: synonym of contrā. $\quad{ }^{3}$ nocte: what question about sequi does this answer? 4 scire: know' how. ${ }^{5}$ tantum: adverb, only. ${ }^{6}$ sē: to whom does this refer? ${ }^{7}$ Thessaliā: Thessaly, a district of northern Greece. $\quad{ }^{8}$ ūnum : supply locum. $\quad{ }^{9}$ terrārum orbem : the world. ${ }^{10}$ pugnātum est: impersonal. Translate by the personal construction. 11 ingenti contentiōne: answers the question "how" about pugnātum est. $12 \mathrm{ut} \mathrm{.} \mathrm{.} \mathrm{a} \mathrm{auxilia:} \mathrm{gives} \mathrm{the} \mathrm{purpose} \mathrm{of} \mathrm{petiit.}{ }^{13}$ quī: what word is the antecedent? Why is qui put first?

Select from the passage examples of emphatic words or phrases. 


\section{EXERCISE VIII}

Grammar: A. 194. b; 196: 427,3; 496; 563; 574. B. I I $5 ; 232,1$; $337,2, a, c: 295.4: 300,1$. G. 251,1 ; I $29 ; 411 ; 282 ; 546,1,2$; 467. H. $237 ; 483: 638.1 ; 565 ; 649$, II.

Inflection: fīó; diēs: posterus: suus.

Order of words: in all sentences the beginning is a place of emphasis, and there is usually put the emphatic word, phrase, or clause.

Prescribed list:

$\begin{array}{llll}\text { mōs } & \text { mulier } & \text { ūtilius } & \text { potius } \\ \text { ēnūntiāret } & \text { autem } & \text { ubi } & \text { institisset } \\ \text { priusquam } & \text { cupidior } & \text { postrīdiē } & \text { fidem } \\ \text { ēgissent } & \text { tandem } & \text { ôrant } & \text { praeter } \\ \text { licēre } & \text { urgente } & & \end{array}$

HOW PAPIRILS AVOIDED TELLING HIS MOTHER WHAT WAS DONE IN TIIE SENATE

Mōs anteā ${ }^{1}$ senātōribus Rōmae fuit in cūriam cum praetextātīs fỉlīs inire. Forte rès maior quaepiam cōnsultāta ${ }^{2}$ et in diem posterum prōlāta est, placuitque nē quis ${ }^{3}$ eam rem ènūntiāret priusquam dēcrēta esset. Sed māter Papīī̄ puerī, quī cum patre suō in cūriā fuerat, percontāta est fīlium quid in senātū patrēs ègissent. Puer respondit tacendum esse ${ }^{5}$ neque id dìcī licēre. Mulier autem fit audiendī cupidior, ac tandem puer, mātre urgente, ${ }^{6}$ āctum $^{7}$ in senātū dīxit utrum vidērētur ùtilius esse, ūnusne ut duās uxōrēs habēret an ut ūna duōbus nūpta esset. Ubi illa hoc audīvit, domō trepidāns ègreditur, ad cēterāss ${ }^{s}$ mātrōnās sē adfert. Pervēnit ad senātum postrīilē mātrum familiās caterva. Lacrimantēs ${ }^{9}$ ōrant ut ūna potius duōbus nūpta fieret quam ut duae ūnī. Senātōrēs in cūriam ingredientēs mīrābantur quae illa mulierum insānia ${ }^{10}$ et quid sibi postulātiō ${ }^{11}$ ista vellet. ${ }^{12}$ Puer Papirius in medium cūriae prōgressus, quid māter audīre institisset, quid ipse mātrī dixisset, dēmōnstrat. Senātus fidem atque ingenium puerī laudat 
et cōnsultum facit nē posthāe puerī cum patribus in cūriam ineant, praeter illum ūnum Papírium, cui posteā cognōmen ${ }^{13}$ honōris grātiā datum est "Praetextātus." — Aulus Gelluus

\section{VOCABULARY}

cūria, ae, f., schate house

praetextātus, a, um, aicuring the togsa

of boyhood

forte, by' chanci

quispiam, quaepiam, quodpiam, some cōnsultō, I, considèr

placēo, 2, uī, itum, please

dēcernō, 3, crēvī, crētus, decide percontor, $\mathrm{r}$, inquire

tacēo, 2, ūi, itus, be silent (tacit)

uxor, ōris, f., witife

nūpta, married

trepidō, I, be in alarm

caterva, ae, f., crow'd

ingenium, inge' $\mathrm{n} \overline{\mathrm{i}}, \mathrm{n}$., ability

cōnsultum, i, n., decrete

\section{NOTES}

${ }^{1}$ anteā: adverb from ante. $\quad{ }^{2}$ cōnsultāta: est is understood. ${ }^{3}$ quis : pronouns are usually indefinite when they follow nē. $\quad{ }^{4}$ Papirì : genitive. ${ }^{5}$ tacendum esse: impersonal; the form shows necessity. $\quad{ }^{6}$ mātre urgente: this states a reason for the boy's action. ${ }^{7}$ āctum: what mood? Consider dixit. Translate, there had bien a discussion. 8 cēterās: synonym of reliqui. ${ }^{9}$ lacrimantēs: for the meaning, compare the noun lacrima. ${ }^{10}$ insānia: think of the English derivative. ${ }^{11}$ postulātiō: postulō + tiō. 12. sibi vellet: meant. ${ }^{13}$ cognōmen: name. One given because of some characteristic or act.

Think of Finglish words from ēnūntiāret, filium, urgente, ūtilius, fidem, ingenium, facit.

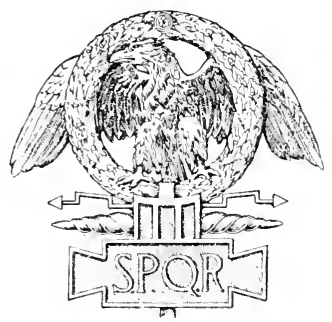

AQUILA LEGIONIS 


\section{EXERCISE IX}

Grammar: A. $405: 410 ;+12 ; 448 ; 540$. B. $216 ; 218,1 ; 220,1$; 2SI; 286.1. G. 40I: 407; 399; 266; 540; 5+I. H. 468; 477 ; 473. 3: 522: 588 , I, II.

Inflection: ùtor; vir; multus (compare); tū.

Order of words: in a clause or sentence words are usually arranged, from the beginning, in the order of their prominence in the thought.

Prescribed list:

$\begin{array}{lll}\text { verbōrum } & \text { plānē } & \text { vīs } \\ \text { cupidissimō } & \text { tū } & \text { scīre }\end{array}$

FAVORINLS GIVES GOOD ADVICE ABOLT THE USE OF IVORDS

Favōrīnus philosophus ${ }^{1}$ adulēscentī, veterum verbōrum ${ }^{2}$ in cotīdiānīs sermōnibus ignōtōrum cupidissimō, "Curius," inquit, "et Fabricius et Coruncānius, antiquissimīi virī, plānē cum suīs locūtī sunt, neque Auruncōrum aut Sicānōrum aut Pelasgōrum, quī prīmī coluisse İtaliam dìcuntur, sed aetătis suae verbīs ūsī sunt; tū autem sermōne abhinc multis annīs iam dēsitō ūteris, quod nēminem vīs scīre atque intellegere quae dīcās. Antīquitātem ${ }^{4}$ tibi placēre ais, quod honesta et bona et modesta sit. Vìve ergō mōribus antīquīs, loquere verbīs praesentibus; atque id, quod à Gāiō Caesare scrīptum est, habē semper in memoriā atque in pectore, ut tamquam saxum sīc fugiās innsolēns verbum." — Aulus Gellius

\section{VOCABULARY}

adulëscēns, entis, m.. f., youth sermō, ōnis, m., talk

ignōtus, a, um, unknozin

inquit (defective verb), say's

colō, 3, colui, cultus, drocll in

aetās, ātis, f., agre

dēsinō, 3. sìvī, situs, lear'e off

piaceō, 2, uī, itum, please aiō (defective verb), $s a y^{\prime}$ vīvō, 3 , vīxī, vīctum, $l \bar{i}^{\prime} \mathcal{E}$ ergō, therefore pectus, oris, n., breast, heart tamquam, as if saxum, i, n.. rock insolēns, entis, unusual 


\section{NOTES}

${ }^{1}$ philosophus: English derivative? $\quad{ }^{2}$ verbōrum: take with cupidissimō. 3 antiquissimi: what is the positive? Synonym of vetus. For the meaning, think of an English derivative. ${ }^{4}$ antiquitātem: formed by attaching a suffix to the stem of the positive of antiquissimi. What is the suffix?

Determine whether the following words are emphatic: (1. I) verbōrum, cotĩdiānìs; (1. 3) plānē; (1.4) prīmì; (1.6) ūteris; (1. I I) însolēns.

\section{EXERCISE $X$}

Grammar: A. 4I 5 ; 546; 573; 574. B. 224; $288,1, \mathrm{~B} ; 300$, i. G. $400 ; 585 ; 452,2 ; 467$. H. 473,$2 ; 600$, II, I $: 649$, II.

Inflection: dō; manus; cōnsulāris; ego.

Order of words: a dependent genitive, unless emphatic, usually follows the word which it limits.

Prescribed list:

ferae

praeter

corpore

fremitū

converterat

$\begin{array}{ll}\text { linguā } & \text { cotīiānīs } \\ \text { mīra } & \text { concessī } \\ \text { quaerit } & \text { dēfuisset } \\ \text { obtinēret } & \text { cibus }\end{array}$

familiāris

tum

mōre

prope

obtinēret

A LION LET LOOSE IN THE AMPIITHEATER REFUSES TO ATTACK ANIROCLUS, BUT FAWNS ON HIN

In circō ${ }^{1}$ maximō vēnātiōnis pugna populō dabātur. Nultae ibi ferae, sed practer alia omnia leō corpore vāstō et fremitū terrificō ${ }^{2}$ animōs oculōsque ${ }^{3}$ omnium in sēsē converterat. Intrōductus ${ }^{4}$ erat inter complūrīs cēterōs ${ }^{5}$ ad pugnam ferārum datōs servus virī cōnsulāris $^{6}$; ễ servō̄ ${ }^{7}$ Androclus nōmen fuit. Hunc ille leō ubi vīdit procul, repente quasi admīrāns stetit ac deinde placidē, tamquam familiāris, ${ }^{8}$ ad hominem accēdit. Tum caudam mōre adūlantium canum blandē movet et manūs hominis, prope iam exanimātī metū, ${ }^{9}$ linguā lēniter dēmulcet. Haec tam mīra rēs maximōs populì clāmōrēs excitat et Caesar Androclum vocat quaeritque causam, cūr illì ūnī atrōcissimus leō pepercisset. Ibi Androclus rem admirandam 
nārrat. "Cum prōvinciam," inquit, "Ā fricam prōcōnsulārī imperiō meus dominus obtinēret, ego ibi inīquīs ${ }^{10}$ eius et cotīdiānīs verberibus ad fugam sum coāctus, et in locōs dēsertōs et remōtōs concessī ac, sì dēfuisset cibus, cōnsilium fuit mortem aliquō pactō quaerere."

\section{Aulus Gellius}

\section{VOCABULARY}
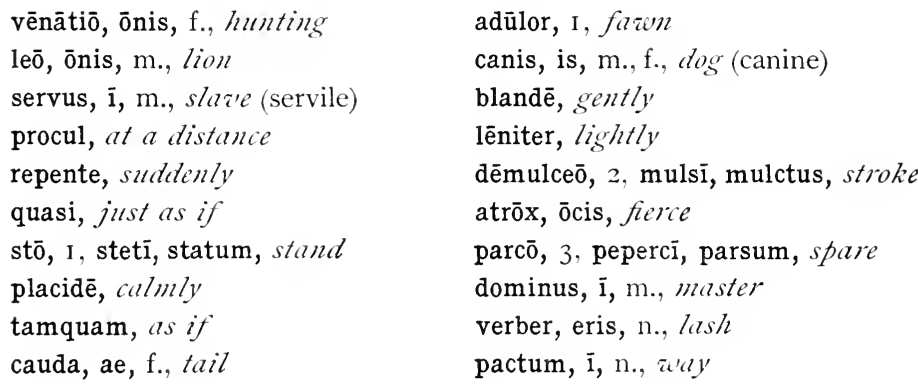

\section{NOTES}

1 circō: think of the English derivative; a place of entertainment. 2 terrificō: there is a common English derivative. ${ }^{3}$ oculōs: from this is derived the word "oculist." $\quad 4$ intrōductus: from intrō, within, + dūcō. 5 cēterōs : synonym of reliquī. $\quad{ }^{6}$ cōnsulāris : from cōnsul $+\bar{a} r i s=$ pertain ing to, of the rank of. 7 servō: a dative, showing the possessor. Translate it as if it were a nominative, and fuit by the appropriate tense of the verb har'e. ${ }^{8}$ familiāris: compare the derivation of this word with that of cōnsulāris. $\quad{ }^{9}$ metū : synonym of timor. $\quad{ }^{19}$ iniquīs : formed from the adjective aequus by prefixing in. Compare the words "convenient" and "inconvenient," "equity" and "iniquity."

Consider the genitives in the passage and decide whether the position of each is emphatic or not. 


\section{EXERCISE XI}

Grammar: A. $400 ; 401 ; 423.2: 500,4: 504, b$. B. $214,1,2 ; 181,1$; $337,8, b, 2: 33^{8}$, I, $c$. G. $390,1: 405: 336 ;+30 ;+28$, R. 2. H. 462 ; $417 ; 622 ; 626,3$.

Inflection: ostendō: ìgnis; tōtus: quī.

Order of words: the following arrangement of the parts of a predicate is common: ablative, indirect object, direct object, adverb, verb.

\section{Prescribed list:}

$\begin{array}{llll}\text { quendam } & \text { cōnspectū } & \text { vīetū } & \text { statim } \\ \text { nanctus } & \text { postquam } & \text { postrēmō } & \text { cūrāvit } \\ \text { vulnerātō } & \text { sublātum } & \text { viam } & \text { quoque } \\ \text { illīic } & \text { tunc } & \text { trīdūi } & \text { beneficī } \\ \text { quidem } & \text { operā } & \text { dēductus } & \end{array}$

ANIROCLUS RELATES IHOW IIE MET THE WOUNDED LION AND GAINED ITS AFFECTION

Tum specum quendam nanctus remōtum, ${ }^{1}$ in eum mē recondō. Neque multō ${ }^{2}$ post ad eundem specum vēnit hīc leō, ūnō pede vulnerātō. Atque illīc prīmō quidem cōnspectū ${ }^{3}$ advenientis ${ }^{4}$ leōnis territus sum; sed postquam intrōgressus ${ }^{5}$ leō mē procul videt, mìtis accessit et sublātum pedem ostendere mihi quasi opis petendae causā vīsus est. Ibi stirpem ingentem, pedī eius haerentem, revellì et sine magnō iam metū cruōrem siccāvī. Illā tunc meā operā levātus, pede in manibus meîs positō, quiērit. Ex eō diē triennium ${ }^{6}$ tōtum ego et leō in eōdem specū eōdemque vīctū vīximus. Postrēmō autem relīqui specum et viam ferē trīduĩ permēnsus à mīlitibus vīsus apprehēnsusque $\operatorname{sum}^{7}$ et ad dominum ex Āfricā Rōmam ${ }^{8}$ dēductus. Is mē statim damnandum dandumque ad ferās cūrāvit. Intellegō autem hunc quoque leōnem captum grātiam mihi nunc beneficī et medicinae referre. Haec dixit Androclus; quae cum scrīpta essent circumlātaque populō, omnibus petentibus dīmissus Androclus et poenā solūtus est et lē̄ne dōnātus. ${ }^{9}$ 


\section{VOCABULARY}

specus, ūs, m., car'e

recondō, 3, didī, ditus, hide away

terrēo, 2. uī, itus, firghten

mitis, e, mild

(ops), opis, f., aid

stirps, pis, f., root

ingēns, ingentis, luzge

haerē̄, 2, haesī, haesus, stick

revellō, 3, vellī, vulsus, tear away

cruor, ōris, m., blood

siccō, I, diry levō, I, reliez'c

quiēscō, 3, ēvī, ètus, rest (quiet)

vīvō, 3, vīxī, vīctum, liz'e

permētior, 4, mēnsus, tracierse

damnō, I, condemn

medicina, ae, f., relief

scrībō, 3, scrīpsī, scrīptus, write (script)

poena, ae, f.. punishment

solvō, 3, solvī, solūtus, release (solve)

\section{NOTES}

1 remōtum: notice that this word is made emphatic by separating it from the word which it modifies. 2 multõ : take with post, an adverb. ${ }^{3}$ conspectū: from con + spec + tus. Give the force of each one of these. ${ }^{4}$ advenientis : note the force of the prefix, towials. 5 introgressus: think of prōgressus. The prefix intrō means within. ${ }^{6}$ triennium: from the stems of trēs and annus. $\bar{\top}$ apprehēnsus sum: from ad + prehendō. What common English word from this? What meaning has it? ${ }^{8}$ Rōmam: not the object of dēductus. $\quad{ }^{9}$ dōnātus : think of a common English word from this, and its meaning.

Observe the force of the prefixes in this passage: remōtum, accessit, permēnsus, dēductus, referre, circumlāta, and others.

\section{EXERCISE XII}

Grammar: A. 3+3: $405: 418 ;+19 ; 54^{6}$. B. I95; I9S: $216 ; 226$; 227 ; $28 S$, I, B. G. 362: toI ; 397 ; to9; 585 . H. t+o, I; 468; 48O; $489 ; 600,11,1$.

Inflection: patior; latus (noun); celeriter (compare); idem.

Order of words: limiting words, when emphatic, usually stand between a preposition and the word which the preposition governs.

Prescribed list:

nōmine

immisit

manum vulneribus

medīs rettulit

statim 
THE AFFECTION AND LOYALTY OF A FAMOUS IIORSE

Equus Alexandrī rēgis nōmine Būcephalus fuit. I)è hōe equō haec memoriā digna ${ }^{1}$ accēpimus. Ủbi ōrnātus erat armātusque ad proelium, haud umquam inscendī sēse ${ }^{2}$ ab aliō nisi ab rēge passus est. Bellō $\overline{3}^{3}$ Indicō cum insidēns in eō Alexander facinora faceret fortia, in hostium manum, nōn satis sibi prōvidēns, immīsit. Coniectīs undique in Alexandrum tēlìs, vulneribus altīs in cervice atque in latere equus perfossus est. Moribundus tamen ac prope iam exsanguis è medīis hostibus rēgem celeriter rettulit atque, ubi eum extrā ${ }^{4}$ tēla extulerat, ${ }^{5}$ statim concidit et animam ${ }^{6}$ exspīrārit. 'Tum rēx Alexander, partā eius bellî victōriā, oppidum in ī̄slem locīs condidit idque ob equī honōrēs Būcephalon ${ }^{7}$ appellāvit.

Aulus Gellius

\section{VOCABULARY}

Alexander, drī, m., Alexander the

Great, king of Macedonia

dignus, a, um, worthy.

ōrnō, I, equip (ornament)

haud, not at all

umquam, evier

īnscendō, 3 , scendī, scēnsus, mount

însideō, 2, sēđī, sessus, sit (on)

facinus, oris, n., devel cervix, īcis, f., neck

perfodiō, 3, fōdī, fossus, pierce through

moribundus, a, um, dying

exsanguis, e, lificless

concidō, 3, cidi, —, collapse

exspīō, I, breathe out

pariō, 3, peperī, partus, achier'e condō, 3, didì, ditus, found

\section{NOTES}

1 digna: followed by the ablative. ${ }^{2}$ sēsê: for the case, consider the voice of inscendī. ${ }^{3}$ bellō: answers the question "when" about faceret. 4 extrā: what does the word "extraordinary" mean? What is the force of the prefix? 5 extulerat: get the meaning from the two parts of the word. 6 animam: synonym of vita, found in the English words "vital," "vitality." ${ }^{7}$ Būcephalon: accusative singular.

Observe the many words with prefixes in this passage and try to decide what each prefix means. 


\section{EXERCISE XIII}

Grammar: A. $38+4$ 4I 2; 426, 2, 3; 580. B. I 92, I ; 220, I ; I 82, 2 ; 228: 3I4, I. G. 359; 399; +I6, I; +18, I, $a, b ; 650$. H. +34, 2; 473,$3 ; 418 ; 483: 642: 6+3$.

Inflection: fīō; terra: bonus (compare); quīdam.

Order of words: an appositive usually follows the word to which it belongs.

Prescribed list:

$\begin{array}{llll}\text { accūsāvit } & \text { nōmine } & \text { adversum } & \text { sententiam } \\ \text { mollibus } & \text { quaedam } & \text { hinc } & \text { inde } \\ \text { pāx } & \text { tum } & \text { āvertit } & \text { prōsecūta est }\end{array}$

HOW SCIPIO REPELLED THE CHARGE OF HAVING TAKEN A BRIBE

Mārcus Naevius, tribūnus plēbis, accūsāvit Scīpiōnem ${ }^{1}$ ad populum, dīxitque eum accēpisse ā rēge Antiochō pecūniam, ut condiciōnibus mollibus pāx cum eō populī Rōmānī nōmine fieret, et quaedam item alia indigna ${ }^{2}$ tālì virō addidit. ${ }^{3}$ Tum Scīpiō pauca praefātus, quae dignitās ${ }^{4}$ vìtae suae atque glōria ${ }^{5}$ postulābat, "Memoriā," inquit, " ( )uirîtēs, ${ }^{6}$ repetô, ${ }^{7}$ diem esse hodiernum, quō Hannibalem Poenum, imperiō vestrō inimìissimum, ${ }^{8}$ magnō proeliō in terrā Āfricā vīcī, pācemque et victōriam vōbīs peperī praeclāram. Nōn igitur sìmus ${ }^{9}$ adversum deōs ingrātī et, cēnseō, relinquāmus nebulōnem hunc, eāmus hinc prōtinus ${ }^{10}$ Iovī optimō maximō grātulātum." 11 Id cum dixisset, āvertit et īre ad Capitōlium coepit. Tum cōntiō ūniversa, quae ad sententiam dē Scīpiōne ferendam convēnerat, relictō tribūnō Scīpiōnem in Capitōlium comitāta, atque inde ad aedēs ${ }^{12}$ eius cum laetitiā prōsecūta est. - Aulus Gellius

\section{VOCABULARY}

plēbs, plēbis, f., common people pecūnia, ae, f., moncy (pecuniary) tālis, e, such (praefor), fārī, fātus, say beforchand vita, ae, f., life (vital) inquam (defective verb), say 
hodiernus, a, um, to-day's

pariō, 3, peperī, partus, achiez'e

praeclārus, a, um, famous

igitur, therefore

deus, i, m., god

cēnseō, 2, uī, us, propose, moz'e nebulō, ōnis, m., paltry fellow

grātulor, I, give thanks

cōntiō, ōnis, m., assembly'

comitor, I, accompany

laetitia, ae, f., joy

\section{NOTES}

${ }^{1}$ Scipiōnem: Publius Cornelius Scipio Africanus, who defeated Inannibal at Zama. 2 indigna: from in + dignus, worthy. What is the force of the prefix? Think of "convenient" and "inconvenient." ${ }^{3}$ addidit: get the meaning from the English derivative. "dignitās: from dignus and what suffix? What is the real meaning of the word? ${ }^{5}$ glöria: think of the English word. $\quad{ }^{6}$ Quirīēes: Roman citizens. ${ }^{7}$ repetō: derive the meaning from the prefix and the verb. 8 inimicissimum: from in + amicus. Compare indignus above. $\quad{ }^{9}$ simus: introduce the translation of this and the following subjunctives by let. ${ }^{10}$ prōtinus: synonym of statim. 11 grātulātum: notice that this looks like a participle, but does not agree with any other word. It shows purpose. 12 aedēs: synonym of domus.

Note the position of the appositives in the passage.

\section{EXERCISE XIV}

Grammar: A. $346, a, 3 ; 405 ; 409 ; 53 \mathrm{I}, \mathrm{I} ; 580 . \quad$ B. 201, 2; 216 ; $2 \mathrm{I} 8 ; 282$ I ; 3I4, I. G. $369 ; 40 \mathrm{I} ; 545, \mathrm{I}, 3 ; 650$. H. $441 ; 468$; $476 ; 568 ; 6+2 ; 643$.

Inflection: doceō; domus ; omnis ; is.

Order of words: indefinite pronouns are usually unemphatic and follow their nouns.

\section{Prescribed list:}

locūtus erat

familiārēs

prōsequēbāmur

subeuntēs

cōnspicimus
quandam
èditam
ignī

$\begin{array}{ll}\text { propinqua } & \text { praefectus } \\ \text { vēndidissem } & \text { turrim } \\ \text { ēmissem } & \text { latere } \\ \text { docuisset } & \end{array}$

\section{HOW TO MAKE BUILUINGS FIREPROOF}

Locūtus erat Antōnius Iūliānus rhētor fèlicissimē eumque nōs, familiārēs ${ }^{1}$ eius, prōsequēbāmur domum, cum subeuntēs montem Cispium $^{2}$ cōnspicimus insulam ${ }^{3}$ quandam, multīs altīsque tabulātīs 
èditam, īgnì occupātam ${ }^{4}$ et propinqua iam omnia flagrāre vāstō incendiō. ${ }^{5}$ Tum quispiam ${ }^{6}$ ibi ex comitibus Iūliānī, "Magnì," inquit, "reditūs ${ }^{i}$ urbānōrum praediōrum, sed perīcula sunt longēē maxima. Sì quid autem posset remedī ${ }^{8}$ esse, nē domūs Rōmae ārdērent, rēndidissem ${ }^{9}$ rēs rūsticās et urbicās ${ }^{10}$ ēmissem." Atque illī Iūliānus, "Sì annālem," inquit, "ūndēvīcèsimum Quīntī Claudī lēgissēs, docuisset tē profectō Archelāus, rēgis Mithridātīin praefectus, quōo ${ }^{12}$ remediō ìgnem dēfenderēs. In eō enim librō scrīptum invēnì, ${ }^{13}$ cum oppugnāret Lūcius Sulla in terrā Atticā Pīraeum et contrā Archelāus, rēgis Mithridātī praefectus, ex eō oppidō prōpugnāret, ${ }^{14}$ turrim ligneam dēfendendī causā strūctam, ex omnī latere circumplexam īgnī, ārdēre nōn potuisse, quod alūmine ab Archelāō oblita fuisset." 15 _ Aulus Gellius

\section{VOCABULARY}

rhètor, oris, m., teacher of oratory fēlīciter, happily

tabulātum, i, n., floor, story

flagrō, I, be on fire

vāstus, a, um, enormous

comes, itis, m.. f., companion

inquam (defective verb), say

urbānus, a, um, of the city' (urbane)

praedium, praedi, n., estate

ārdeō, 2. ārsī, ārsūrus, burn (ardent)

rūsticus, a, um, of the country

annālis, is, m., chronicle

ūndēvīcēsimus, a, um, nineteenth legō, 3, lēgī, lēctus, read

profectō, assuredly

liber, librī, m., book

scrībō, 3, scrīpsī, scrīptus, write (scribe)

ligneus, a, um, wooden

struō, 3, strūxī, strūctus, erect (structure)

circumplectō, 3, - , plexus, encircle

alūmen, inis, n., alım

oblinō, 3, lēvī, litus, smear

\section{NOTES}

${ }^{1}$ familiārēs: used as a noun. 2 Cispium: a part of the Esquiline hill. ${ }^{3}$ insulam: tencment building. ${ }^{4}$ occupātam: supply esse. ${ }^{5}$ incendiō: from the verb incendo and the suffix ium, showing action. ${ }^{6}$ quispiam: synonym of aliquis. ' reditūs: noun from the verb redeō. ${ }^{8}$ reme'di : genitive. Get the meaning from the English derivative. ${ }^{9}$ vēndidissem: this is in the conclusion of an unreal condition. ${ }^{10}$ urbicās: synonym of 
urbānus. 11 Mithridātī: genitive. Mithridates, king of Pontus, in Asia Minor. ${ }^{12}$ quō: interrogative; this clause is the second object of docuisset. 13 invēnì : in + veniō, come upon. ${ }^{14}$ prōpugnāret: note the prefix and its force. $\quad 15$ fuisset: used instead of esset.

Think of English words from locūtus erat, rhētor, cōnspicimus, insulam, rēgis, ignem.

\section{EXERCISE XV}

Grammar: A. $34^{6}, a, 3 ; 3 \delta_{4} ;+56 ; 530 ; 531,1 ; 568$. B. 201,1 : 192, I; 32S. I; 2S2, I : 297, I. G. 369; 359; +23, 1, 2; 5+5, I, 3 ; 553, 1. H. $4+2: 434,2 ; 607,1 ; 568: 566$.

Inflection: possum; filius; dulcis; hìc.

Order of words: possessive adjectives, unless emphatic, stand after their nouns.

\section{Prescribed list:}

- frātris

$$
\text { redeo }
$$

liberīs

experior

efficiam

oportet

quaererem

studiīs

dēbeō

aequō

beneficiō

sentiam

enim

subire

suscipiendās

\section{PLINY WRITES TO A FRIEND ON THE CHOICE OF A BOY'S' SCHOOL}

Quid iūcundius mihi esse potuit quam ut praeceptōrem frātris tuī lỉberīs quaererem? Nam beneficiō ${ }^{1}$ tuō in scholam redeō et illam dulcissimam aetătem quasi ${ }^{2}$ resūmō. ${ }^{3}$ Sedeō inter iuvenēs, ut solēbam, atque etiam experior quantum apud illōs auctōritātis ex studī̄s habeam. Cum omnīs quī profitentur audierō, quid dē quōque sentiam scrībam, ${ }^{4}$ efficiamque, quantum tamen epistulā cōnsequī poterō, ut ipse omnīs audisse videāris. İēbeō enim tibi, dēbēo memoriae frātris tuī hanc fidem, hoc studium, praesertim super tantā rē. Nam quid magis interest vestrāa ${ }^{5}$ quam ut liberī dignī illō ${ }^{6}$ patre, tē patruō reperiantur? Nec ignōrō suscipiendās offēnsās in ēligendō praeceptōre, sed oportet mē nōn modo offēnsās vērum etiam simultātēs prō frātris tuī fīlī̄s tam aequō animō subire quam parentēs prō suīs. ${ }^{7}$ Valē. — Pliny the Y'ounger 


\section{VOCABULARY}

iūoundus, a, um, pleasant praeceptor, ōris, m., teacher schola, ae, f., school aetās, ātis, f., age sedeō, 2, sēđī, sessum, sit iuvenis, is, m., f., youth (juvenile) soleō, 2, solitus, be accustomed profiteor, 2, fessus, be a teacher scrībō, 3 , scrīpsì, scrīptus, zerite (scripture) epistula, ae, f., letter dignus, a, um, worthy patruus, $\overline{\mathrm{i}}, \mathrm{m}$., uncle ignōrō, $\mathbf{1}$, be unazeare (ignorant)

offēnsa, ae, f., inconvenience èligō, 3, lēgī, lēctus, select simultās, ātis, f., jealousy

\section{NOTES}

1 beneficiō: shows cause, thanks to. ${ }^{2}$ quasi: as it aere. ${ }^{3}$ resūmō: from re + sūmō. Give an English verb from this word. ${ }^{4}$ scribam: the preceding clause is its object. 5 interest vestrāa concerns you. Vestrā is the ablative singular feminine of the possessive pronoun, governed by interest. $\quad{ }^{6}$ illō: the ablative follows dignus. Patre is an appositive of illō. 7 suis : understand fïliīs.

\section{EXERCISE XVI}

Grammar: A. +19; 420. 1: 423, 2; 427, 2, 3. B. 227, 2, $a$; I 8 I, I ; I 82, I, a; 228, 1, a. G. 409; 410;336; 337; 386. H. 489, I; 4I 7; 491, II, I, 3 .

Inflection: sequor; mors; tötus; ille.

Order of words: the place of emphasis in the clause or sentence is usually the beginning.

Prescribed list:

$\begin{array}{llll}\text { ācrius } & \text { manibus } & \text { vigiliam } & \text { manēbat } \\ \text { strepitus } & \text { catēnās } & \text { quoque } & \text { pretiō } \\ \text { deinde } & \text { inde } & \text { discesserat } & \text { condūcit } \\ \text { cōnfectus } & & & \end{array}$

\section{ATHENODORUS HIRES A HAUNTED HOUSE}

Erat Athēnīs spatiōsa ${ }^{1}$ et capāx ${ }^{2}$ domus, sed īnfāmis et pestilēns. Per silentium ${ }^{3}$ noctis sonus ferrī et, sī attenderēs ${ }^{4}$ àcrius, strepitus vinculōrum, longius prīmō, deinde $\overline{\mathrm{e}}$ proximō, audiēbātur; mox appārēbat ìdōlon, senex maciē et squālōre cōnfectus, prōmissā 
barbā, manibus catēnās gerēbat quatiēbatque. ${ }^{5}$ Inde inhabitantēs trīstīs noctīs per metum ${ }^{6}$ vigilābant. Vigiliam morbus et, crēscente ${ }^{7}$ metū, mors sequēbātur. Nam interdiū quoque, quamquam discesserat imāgōo, memoria imāginis manēbat. Dēserta inde erat domus et tōta illī mōnstrō relicta. Vēnit Athēnās philosophus Athēnodōrus, vỉdit titulum, auditōque pretiō omnia cognōvit ac nihilōminus ${ }^{8}$ eam condūcit. ${ }^{9}$ - Pliny The Younger

\section{VOCABULARY}

infāmis, e, of ill repute

pestilēns, entis, unhealthy

sonus, $\overline{1}, \mathrm{~m}$., sound

ferrum, $\overline{1}, \mathrm{n} .$, iron

vinculum, $\bar{i}$, n., fetter

mox, soon

appārē̄, 2, uī, - .., appear

ìdōlon, ì, n., ghost

senex, senis, m., old man

maciēs, èì, f., leanness squālor, ōris, m., filth

prōmittō, 3, mīsì, missus, let grow barba, ae, f., beard

quatiō, 3, - quassus, shake

trīstis, e, sad

vigilō, I, keep awake (vigil)

morbus, i, m., sickness (morbid)

interdiū, by day

quamquam, although

titulus, i, m., placard "for rent"

\section{NOTES}

${ }^{1}$ spatiōsa: spatium $+\bar{o} s u s$, full of. 2 capāx: synonym of magnus. English derivative? 3 silentium: think of the English derivative. ${ }^{4}$ attenderēs: see note on silentium. 5 quatiēbat: all the verbs thus far are in this tense. Why? ${ }^{6}$ metum: synonym of timor. ${ }^{7}$ crēscente: synonym of augeor. ${ }^{8}$ nihilōminus: nihil + minus. ${ }^{9}$ condūcit: rents.

From many of the words in the passage are derived common English words. Make a list.

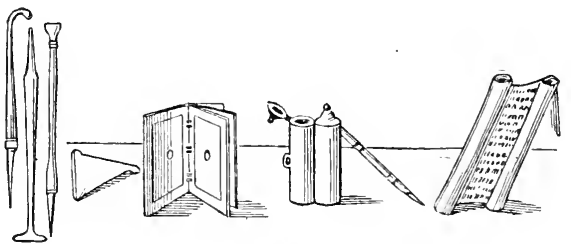

WRITING MATERIALS 


\section{EXERCISE XVII}

Grammar: A. $3^{8}+401 ; 409 ; 412 ; 506 ; 563$. B. 192, I : 214. I, c ; $218 ; 220,1 ; 338,3 ; 295,1$. G. $359 ; 405: 401 ; 399 ; 432$, R.; 546, I. H. 434,$2 ; 462 ; 476 ; 473,3 ; 628 ; 565$.

Inflection: ē̄; locus; posterus (compare); ipse.

Order of words: a word, phrase, or clause is more likely to limit a word which follows it than one which precedes it.

Prescribed list

$\begin{array}{llll}\text { poscit } & \text { initiō } & \text { intrā } & \text { adiit } \\ \text { vacua } & \text { tollere } & \text { respicit } & \text { posteā } \\ \text { fingeret } & \text { appropinquāre } & \text { morātus } & \end{array}$

\section{ATHENODORUS CAUSES THE GHOST TO DEPART FROM THE HAUNTED HOUSE}

Ubi coepit advesperāscere, ${ }^{1}$ Athēnodōrus poscit pugillārēs, stilum, lūmen ${ }^{2}$; suōs omnis in interiōra dìmittit; ipse ad scrībendum animum, oculōs, manum intendit, nē vacua mēns $^{3}$ sibi metūs fingeret. Initiō silentium ${ }^{4}$ noctis; deinde concutī ferrum, vincula movērī. Ille nōn tollere oculōs, nōn remittere stilum. Tum crēscere strepitus, appropinquāre et iam ut in lìmine, iam ut intrāā līmen audīrī. Respicit, videt nārrātam sibi imāginem. Stābat innuēbatque digitō similis vocanti..$^{5}$ Athēnodōrus nōn morātus tollit lümen et sequitur. İbat illa ${ }^{6}$ lentō gradū ${ }^{7}$ quasi gravis vinculīs in āream domūs, repente dilāpsa dēserit comitem. Dēsertus herbās ${ }^{8}$ et folia coācta signum locō pōnit. Posterō diē adiit magistrātus, monet ut illum locum effodī iubeant. Inveniuntur ${ }^{9}$ ossa inserta catēnìs; collēcta pūblicē sepeliuntur. Iomus posteā mōnstrō caruit. - Pliny THE Younger

\section{VOCABULARY}

pugillārēs, ium, m., writing tablets stilus, i, m., stylus, used for writing scrībō, 3, scrīpsī, scrīptus, write oculus, $\overline{\mathrm{i}}, \mathrm{m}$. , eve (oculist) intendō, 3, tendī, tentus, direct (intention)

concutiō, 3, cussī, cussus, shake (concussion) 
vinculum, i, n., fetter

limen, inis, n., threshold

stō, I. stetī, statum, stand

innuō, 3, nuī, nūtum, beckon

digitus, $\overline{1}, \mathrm{~m}$., finger

vocō, 1. call (vocation)

lentus, a, um, slow

gradus, ūs, m., step (grade)

quasi, as if ārea, ae, f., court

repente, suddenly'

dīlābor, 3, lāpsus, glide away'

comes, itis, m., f., companion

folium, foli, n., leaf

effodiō, 3. fōdì, fossus, dig up

$\overline{\mathrm{os}}$, ossis, n., bone (ossify)

sepeliō, + , ìvī, sepultus, bury

careō, 2, ūi itūrus, be friete from

\section{NOTES}

1 advesperāscere: from ad + the stem found in vesper $+\mathrm{sco}$, which denotes that the action is beginning. $\quad 2$ lümen: synonym of $l \bar{x} x . \quad 3$ mēns: synonym of animus. $\quad{ }^{4}$ silentium: English derivative? ${ }^{5}$ vocanti : take with similis and think of it as having the force of a noun. ${ }^{6}$ illa: refers to imāginem. " 7 gradū : answers the question " how" about ibat. ${ }^{8}$ herbās : turf. 9 inveniuntur: in + veniō, come upon.

Observe that several of the principal verbs in the passage, such as concuti, are in the infinitive mood. This adds vividness and an air of animation to the narrative. They should be translated by the indicative mood. The infinitive thus used is called the historical infinitive. Observe also the omission of conjunctions.

\section{EXERCISE XVIII}

Grammar: A. $496 ; 5+0 ; 54^{6} ; 580: 585$. B. $337.2 . a, f ; 286,1$; 288, I, B; 3I +. I; 3IS. G. $665 ; 666 ; 5+1 ; 585 ; 650 ; 654$. H. 638, I ; $5 S 8, \mathrm{I}, \mathrm{II} ; 600, \mathrm{II}, \mathrm{I} ; 642 ; 643 ; 6+4$.

Inflection: reperiō: iter; alter; $\overline{\mathrm{d}} \mathrm{dem}$.

Order of words: temporal clauses usually precede, and purpose clauses usually follow, the verb on which they depend.

Prescribed list:

$\begin{array}{llll}\text { crēberrimē } & \text { redīsse } & \text { hospitium } & \text { portam } \\ \text { ignōtum } & \text { trāditum } & \overline{\text { ōāre }} & \text { priusquam } \\ \text { quendam } & \overline{\text { ūnā }} & \text { quoniam } & \text { quaesīsse } \\ \text { cōnscendere } & \text { hospitem } & \text { paterētur } & \text { fūgisse } \\ \text { nāvigāsset } & & & \end{array}$


TWO STRANGE DREAMS, THROUGH ONE OF WHICH A CRIME WAS DETECTED AND PUNISHED

Duo somnia crēberrimē commemorantur: ūnum dē Simōnide, quī, ${ }^{1}$ cum ignōtum quendam prōiectum mortuum vīdisset eumque humāvisset habēretque in animō nāvem cōnscendere, monērī vīsus est nē id faceret ab eō quem sepultūrā affēcerat; sī nāvigāsset, ${ }^{2}$ eum naufragiō esse peritūrum. Itaque Simōnidem redīsse ${ }^{3}$; perīsse cēterōs, ${ }^{4}$ quī tum nāvigāssent.

Alterum ita trāditum est. ${ }^{5}$ Cum duo quīdam Arcades ${ }^{6}$ familiārēs iter ūnā facerent et Megaram ${ }^{7}$ vēnissent, alterum ad caupōnem dēvertisse, ${ }^{8}$ ad hospitem alterum. Vìsum esse ${ }^{9}$ in somnīs ${ }^{10}$ ei quī erat in hospitiō ${ }^{11}$ illum alterum ōrāre ut subveniret, quod ${ }^{12}$ sibi ā caupōne interitus ${ }^{13}$ parārētur; eum prīmō perterritum somniō surrēxisse ; dein ${ }^{14}$ cum sē collēgisset idque vīsum prō nihilō habendum esse dūxisset, ${ }^{15}$ recubuisse. Tum eī dormientī eundem illum vīsum esse rogāre ut, quoniam sibi ${ }^{16}$ vīvō nōn subvēnisset, mortem suam nē inultam ${ }^{17}$ esse paterētur ; sē interfectum in plaustrum ā caupōne esse coniectum; petere ut māne ad portam adesset, priusquam plaustrum ex oppidō exīret. Hōc somniō eum commōtum, māne ad portam fuisse, quaesīsse ex bubulcō quid esset in plaustrō ; illum perterritum fūgisse, mortuum repertum esse; caupōnem, rē patefactā, ${ }^{18}$ poenās dedisse. - CicERo

\section{VOCABULARY}

somnium, somnī, n., dream commemorō, I, relate

morior, 3, mortuus, die (mortal)

humō, I, bury

sepultūra, ae, f., burial

naufragium, naufra'gī, n., wreck

pereō, 4. īi, itūrus, perish

caupō, ōnis, m., innkecper

subveniō, 4 , vēni, ventum, come to

the aid of surgō, 3, surrēxī, surrēctus, rise (surge)

colligō, 3, lēgī, lēctus, collect recumbō, 3 , cubuī, _- lie dow'n again

dormiō, + , ìvī, ìtum, sleep(dormant) plaustrum, i, n., cart

māne, earrly

adsum, esse, fuī, __, be at hand bubulcus, i, m., plonghman 


\section{NOTES}

${ }^{1}$ quĩ : take with vīsus est. $\quad{ }^{2}$ nāvigāsset: indirect discourse dependent on monērī. $\quad{ }^{3}$ redīsse : indirect discourse dependent on commemorantur. ${ }^{4}$ cēterōs: synonym of reliquī. $\quad{ }^{5}$ trāditum est: the story is told in indirect discourse dependent on this verb. ${ }^{6}$ Arcades: Grecks. ${ }^{7}$ Megaram: a town in Greece. ${ }^{8}$ dēvertisse: dē + vertō. ${ }^{9}$ vīsum esse: the principal verb in the sentence. ${ }^{10}$ somnis : synonym of somniīs. ${ }^{11}$ hospitiō: i.e. in his friend's house. 12 quod: because. 13 interitus: synonym of mors. $\quad 14$ dein $:=$ deinde. $\quad 15$ dūxisset: had considered. $\quad 16$ sibi: for the case, consider subvēnisset. $1_{\bar{i}}$ inultam: compare ulcīscor and in, as in "inconvenient." $\quad{ }^{18}$ patefactā: pateō + faciō.

Study the use of the pronouns in the passage, and observe to which one of the three characters in the story each refers.

\section{EXERCISE XIX}

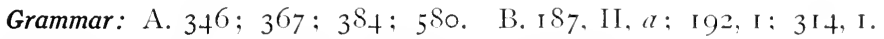
G. $346 ; 359: 650$. H. 426,$1 ; 434,2: 6+2: 6+3$.

Inflection: possum; gēns; nūllus; quī.

Order of words: the normal order of the sentence is: (I) subject; (2) modifiers of subject; (3) modifiers of verb: (4) verb. Changes in this order are due to emphasis.

\section{Prescribed list:}

$\begin{array}{llll}\text { paucōs } & \text { veterēs } & \text { ultimus } & \text { caput } \\ \text { statim } & \text { corpus } & \text { excēdēbat } & \text { stīpendiō } \\ \text { convertit } & \text { statiōnēs } & \text { meruit } & \text { impositō } \\ \text { redditum esse } & \text { peditum } & \text { statuit } & \end{array}$

TIE CHARACTER OF HANNIBAL AND IIS ACTIVITY IN SPAIN

Hannibal $^{1}$ post prīmum I'ūnicum² bellum blandiēbat patrī Hamilcarī ut in Hispāniam dūcerētur. I)ixit sē hostem futūrum esse populō Rōmānō. Post paucōs annōs missus est Hannibal in Hispāniam. Statim omnem exercitum in sē convertit. Hamilcarem iuvenem redditum esse sibi $^{3}$ veterēs mīlitēs crēdidērunt. Et imperātōrì ${ }^{4}$ et exercitūi cārus erat. Nūllō labōre aut corpus fatīgārî̀ ${ }^{5}$ 
aut animus vincī poterat. Multī saepe humī ${ }^{6}$ eum iacentem inter statiōnēs mìlitum vīdērunt. Equitum peditumque longē prīmus erat. Princeps in proelium ỉbat, ${ }^{\top}$ ultimus è proeliō excēdēbat. Trīs annōs sub Hasdrubale ${ }^{8}$ imperātōre meruit. Ex quō diē Hannibal dux dēclārātus est, Saguntīnīs ${ }^{9}$ bellum inferre statuit. In Olcadum prius fīnīs exercitum dūxit. Cartalam, caput gentis eius, expugnāvit. Minōrēs cìvitātēs, stīpendiō impositō, imperium accēpērunt. Victor exercitus Carthāginem Novam in hỉberna dēductus est. - Livy

\section{VOCABULARY}

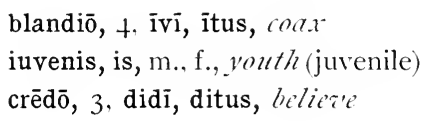

blandiō, 4 , ivīi, itus, $\operatorname{coc} x$ iuvenis, is, m., f., youth (juvenile) crēdō, 3, didì, ditus, beliec'e

\section{NOTES}

1 Hannibal: famous leader of the Carthaginians in the second Punic war. ${ }^{2}$ Pünicum: Punic. ${ }^{3}$ sibi: refers to the subject of the principal verb. ${ }^{4}$ imperātōrī : imperō + tor. $\quad{ }^{5}$ fatīgārī: English derivative? ${ }^{6}$ humì : locative. ${ }^{7}$ ibat: this tense expresses a customary action. ${ }^{8}$ Hasdrubale: Hannibal's brother-in-law. ${ }^{9}$ Saguntīnis: people of Saguntum, a large city of Spain. For the case, consider inferre.

The passage contains variations from the normal order of the sentence. Account for them.

\section{EXERCISE XX}

Grammar: A. $402 ; 506 ; 540 ; 546 ; 563$. B. $214.2: 338,3: 286$, I ; 288,1, B; 295,1 . G. 390.2 ; 432 , R.; $540: 585 ; 546,1$. H. $4^{6}+$ : $628 ; 588, \mathrm{I} ; 600, \mathrm{II}, \mathrm{1} ; 565$.

Inflection: ferō: agmen: gravis; hìc.

Order of words: the following arrangement of the parts of a predicate is common: ablative, indirect object, direct object, adverb, verb.

Prescribed list:

$\begin{array}{llll}\text { vì } & \text { aquam } & \text { cessisse } & \text { nōndum } \\ \text { adortī } & \text { quadrāgintā } & \text { sublātō } & \text { ōrārent } \\ \text { praedā } & \text { autem } & \text { priusquam } & \text { tunc } \\ \text { rīpam } & \text { dispōnit } & \text { praeter } & \text { sententia }\end{array}$


HANNIBAL SUBDUES MANY MORE OF THE TRIBES OF SPAIN

Prīmō vēre in Vaccaeōs prōmōtum est ${ }^{1}$ bellum. Hermandica et Arbocala, eōrum urbès, vī captae sunt. Arbocala et virtūte et multitūdine oppidānōrum ${ }^{2}$ diū dēfēnsa est. Ab Hermandicā profugî̀ concitant Carpētānōs et Hannibalem adortî haud procul Tagōo flūmine agmen grave praed $\bar{a}^{3}$ turbāvērunt. Hannibal proeliō abstinuit, castrīsque super rīpam positīs, flūmen vadō trāiēcit. ${ }^{+}$Equitibus monuit ut, cum hostīs ingressōs ${ }^{5}$ aquam vidērent, adorīrentur impeditum agmen. In rīpā elephantōs, quadrāgintā autem erant, dispōnit. Hostēs, quod metū ${ }^{6}$ cessisse crēdēbant Rōmānōs, clāmōre sublātō, sine ūllīus imperiō in flūmen ruunt. Pars magna flūmine absūmpta est. Priusquam postrēmī ā tantō timōre reciperent animōs, Hannibal fugam ex rīpā fēcit vāstātīsque agrīs intrā paucōs diēs hanc gentem quoque in dēditiōnem accēpit. Et iam omnia trāns Hibērum ${ }^{\top}$ praeter Saguntīnōs Carthāginiēnsium ${ }^{8}$ erant. Cum Saguntīnīs bellum nōndum erat. Lēgātī ā Saguntīnīs Rōmam missĩ sunt. Cōnsulēs tunc Rōmae erant Pūblius Cornēlius Scīpiō et Tiberius Semprōnius Longus. Cum lēgātī auxilium ad bellum iam imminēns ōrārent, Saguntum oppugnārī nūntiātum est. Tunc relāta est dē integrō ${ }^{9}$ rēs ad senātum. Haec sententia, quae optima vidēbātur, vīcit, lēgātīque Saguntum ad Hannibalem missī sunt atque inde Carthāginem, sī nōn absisterētur ${ }^{10}$ bellō, ad ducem ipsum dēposcendum. ${ }^{11}$ - Livy

\section{VOCABULARY}

vēr, vēris, n., spring (vernal) profugus, ì, m., exile concitō, I, arouse haud, not, not at all procul, far turbō, 1, throw into confusion abstineō, 2, uī, tentus, refrain super, upon ingredior, 3. gressus, enter crēdō, 3, didì, ditus, belier'e (credit) ruō, 3 , ruī, rutus, rush absūmō, 3, sūmpsī, sūmptus, destroy' immineō, 2, uī, —, threaten (imminent) integer, gra, grum, fiesh, whole (integer) absistō, 3, stitī, —_, cease 


\section{NOTES}

${ }^{1}$ prōmōtum est: prō + moveō. 2 oppidānōrum: from oppidum and the suffix ānus, belong sing to. $\quad{ }^{3}$ praedā: take with grave. $\quad{ }^{4}$ trāiēcit: derivation? A synonym of trānseō. $\quad{ }^{5}$ ingressōs : understand esse. $\quad{ }^{6}$ metū : syñ onym of timor. It answers the question "why" about cessisse. "7ibērum: the largest river of northeastern Spain. ${ }^{8}$ Carthāginiēnsium: the suffix is ensis, belonging to. A predicate genitive showing possession. ${ }^{9}$ dẽ integrō: used adverbially. Compare dē imprōvisōo. ${ }^{10}$ absisterētur: used impersonally. 11 deposcendum: = poscendum. This was to be done in order that he might be punished for breaking the treaty.

\section{EXERCISE XXI}

Grammar: A. $346, a, 2 ; 370 ; 412 ; 546$. B. 201, I ; I87.3 3 220, I ; 288, I, B. G. 369; 347; 399; 585. H. $442 ; 429 ; 473,3 ; 600$, II, I.

Inflection: agō: turris; graviter (compare); is.

Order of words: a genitive, unless emphatic, follows the noun which it limits.

\section{Prescribed list:}

$\begin{array}{llll}\text { dum } & \text { succēēēbat } & \text { vulnerātus } & \text { coortum est } \\ \text { ultrāa } & \text { dēlēcta } & \text { obsidiō } & \text { anceps } \\ \text { aggreditur } & \text { certāmine } & \text { cūrārētur } & \text { expellunt } \\ \text { adversus } & \text { cadēbant } & \text { operum } & \text { redigunt } \\ \text { vīneās } & & & \end{array}$

THE FIERCE ATTACK ON SAGLNTLY, IN WHICH HANNIBAL IS WOLNDED

Dum ea Rōmānī parant cōnsultantque, iam Saguntum summā vī oppugnābātur. Cìvitās ea longēe opulentissima ultrā Hibērum fuit. Hannibal, agrīis vāstātis, urbem aggreditur. Adversus angulum mūrī vinneās agere instituit, per quās ariēs moenibus ${ }^{1}$ admovêrī $^{2}$ posset. $^{3}$ Nōn prōsperēe ${ }^{4}$ autem coeptīs ${ }^{5}$ succēelēbant. Ft turris ingēns imminēbat, et mūrus suprā cēterae ${ }^{6}$ modum $^{7}$ altitūdinis mūnìtus erat, et iuventūs dēlēcta, ubi plūrimum perīculī ac timōris ostendēbātur, ibi rì maiōre obsistēbat. In hōc certāmine haud ferēe plūrēs Saguntinī cadēbant quam Poenī. Hannibal ipse adversum 
femur trāgulā graviter vulnerātus cecidit. Obsidiō per paucōs diēs magis quam oppugnātiō fuit, ${ }^{9}$ dum ${ }^{10}$ vulnus ducis cūrārētur. Per quod tempus ut ${ }^{11}$ quiēs certāminum erat, ita ${ }^{11}$ ab apparātū operum a€ mūnitiōnum nihil ${ }^{12}$ cessātum est. Itaque ācrius dē integrōo ${ }^{13}$ coortum est bellum. Multae partēs mūrī quassātae erant. Trēs turrēs quantumque inter eās mūrī erat cum fragōre ingentī prōcidērunt. ${ }^{1+}$ Cum diū anceps fuisset certāmen, clāmōrem repente oppidānī ${ }^{15}$ tollunt hostemque in ruinās mūrì expellunt et postrēmō in castra redigunt. — LIVY

\section{VOCABULARY}

opulentus, a, um, re'althy

urbs, urbis, f., city

angulus, i, m., corner

ariēs, etis, m., battoringram

ingēns, ingentis, huge

immine $\overline{0}, 2, \mathrm{u} \overline{\mathrm{i}}, \longrightarrow$, or'erhang

suprā, beyoind

iuventūs, ùtis, f., youth femur, feminis, n., thigh trāgula, ae, f., dart apparātus, ùs, m., friparation cessō, I, ccasé integer, gra, grum, fiesh quassō, I, shake fragor, ōris, m., crash repente, suddenly

obsistō, 3 , stitī, stitus, stand in the way

\section{NOTES}

1 moenibus: synonym of mūrus. For the case consider admovērī. 2 admoverrī : ad + moveō. ${ }^{3}$ posset : shows the purpose of instituit. ${ }^{4}$ prōsperē: English derivative? ${ }^{5}$ coeptīs : participle of coepī used as a noun. ${ }^{6}$ cēterae: synonym of reliquus. ${ }^{7}$ modum : limit. ${ }^{8}$ haud ferē: hardly. ${ }^{9}$ fuit: it was. $10 \mathrm{dum}$ : with the subjunctive, until. 11 ut, ita: correlatives. 12 nihil : adverbial accusative of degree. ${ }^{13}$ dē integrō: used adverbially. Compare dē imprōvīsō. $\quad{ }^{14}$ prōcidērunt: prō + cadō. ${ }^{15}$ oppidānī: from oppidum and the suffix ānus, belonging to.

Make a list of the phrases consisting of a noun and limiting genitive, and determine the emphatic word in each phrase. 


\section{EXERCISE XXII}

Grammar: A. 404: +12; 531, 1; 540; 549. B. $219 ; 220,1$; 282, 1; 286, I, 2. G. $408 ; 399 ; 545,1 ; 540 ; 586$. H. $475 ; 473,3 ; 568$; 588,$1 ; 598$.

Inflection: respondeō; opus ; minor; suus.

Order of words: the limiting word usually precedes the word which it limits, unless the latter is emphatic.

\section{Prescribed list:}

$\begin{array}{llll}\text { nūntius } & \text { vetus } & \text { adorta est } & \text { minuitur } \\ \text { lēgātiō } & \text { aliquot } & \text { simul } & \text { paulisper } \\ \text { inde } & \text { reficerent } & \text { inopia } & \text { profectiō } \\ \text { ortum } & \text { oppugnātiō } & \text { obsidiō } & \text { oppressī }\end{array}$

IIANNIBAL FORESTALLS TIE ROMAN EMBASSY AND THEN ATTACKS SAGUNTUM

Interim Rōmā lēgātōs vēnisse nūntiātum est. Appạāēbat ${ }^{1}$ eōs ab Hannibale nōn admissōs ${ }^{2}$ prōtinus $^{3}$ Carthāginem itūrōs esse. Litterās igitur ${ }^{4}$ nūntiōsque ad prīncipēs factiōnis ${ }^{5}$ Barcīnae $^{6}$ praemittit Hannibal ut praeparent suōrum animōs. Itaque, praeterquam quod $^{7}$ admissī audītique sunt, ea quoque vāna ${ }^{8}$ lēgātiō fuit. Hannō ūnus adversus senātum causam foederis magnō silentiō propter auctōritātem suam nōn cum adsēnsū ${ }^{9}$ audientium ēgit. Respōnsum inde lēgātīs Römānīs est, bellum ortum ab Saguntinīs, nōn ab Hannibale esse; populum Rōmānum iniūstēe ${ }^{10}$ facere, sī Saguntīnōs vetustissimae Carthāginiēnsium societātī praepōnat. ${ }^{11}$ Hannibal, quia fessōs ${ }^{12}$ mīlitēs proelī̄s operibusque habēbat, paucōrum iiss diērum quiētem dedit. Saguntīnì ut ā proelīis quiētem habuerant per aliquot diēs, ita nōn nocte, nōn diē umquam cessāverant ab opere, ut novum mūrum ab eā parte quā patefactum ${ }^{13}$ oppidum erat reficerent. Inde oppugnātiō ācrior quam ante eōs adorta est. Utrimque summā vĩ et mūniunt et pugnant; sed interiōra ${ }^{14}$ tuendō minōrem in diēs ${ }^{15}$ urbem Saguntīnī faciunt. Simul crēscit ${ }^{16}$ inopia omnium longā obsidiōne et minuitur exspectātiō externae opis, cum 
tam procul Rōmānī, ūnica ${ }^{1 \overline{ }}$ spēs, essent. Paulisper tamen animōs recreāvit ${ }^{18}$ repentīna profectiō Hannibalis in Ōrētānōs Carpētānōsque, quī duo populī oppressì eius celeritāte omīsērunt mōta arma. Postrēmō ad ipsam arcem ductus est exercitus, atrōxque proelium cum multōrum utrimque caede ${ }^{19}$ initum $^{20}$ et pars arcis capta est. - LIVY

\section{VOCABULARY}

appāreō, 2, uī, — appear (ap-

parent)

praeterquam, except

foedus, eris, n., tricaty

silentium, silentī, n., silence

umquam, ever

cessō, I, cease

tueor, 2 , tuitus or tūtus, protect urbs, urbis, f., city (suburban)

(ops), opis, f., aid

procul, far a way

repentinus, a, um, sudden

omittō, 3, mīin, missus, giv'e up

arx, arcis, f., citcdel

atrōx, atrōcis, dreadful (atrocious)

\section{NOTES}

${ }^{1}$ appārēbat: impersonal. $\quad{ }^{2}$ admissōs : English derivative? $\quad{ }^{3}$ prōtinus : synonym of statim. ${ }^{4}$ igitur: synonym of itaque. ${ }^{5}$ factionnis: English derivative? $\quad{ }^{6}$ Barcinae: adjective. The Barca family, to which Hannibal belonged, was the most powerful in Carthage. ${ }^{7}$ quod: the fact that. ${ }^{8}$ vāna: synonym of vacuus. ${ }^{9}$ adsēnsū : ad + sentiō + tus. English derivative? 10 iniūstē: adverb. ${ }^{11}$ praepōnat: prae, befor ${ }^{\prime}$. ${ }^{12}$ fessōs : = dēfessōs. ${ }^{13}$ patefactum : pateō + faciō. ${ }^{14}$ interiōra : object of tuendō. $\quad 15$ in diēs : day by day. 16 crēscit: think of the meaning of augeō. Crēscō is intransitive. ${ }^{17}$ ünica: synonym of sōlus. ${ }^{18}$ recreàvit: re + creō, here restore. ${ }^{19}$ caede: from the stem of caedō, kill. 20 initum: understand est.

Find examples in the passage for the rules on the order of words.

\section{EXERCISE XXIII}

Grammar: A. $48_{3}: 48_{4}, 1,2: 54^{6}: 5 s_{4}: 5 s_{5}$. B. $267,1,2: 28 s, 1, \mathrm{~B}$ : $317 ; 270, \mathrm{I}, a, b, c ; 3 \mathrm{I} S$. G. 509, I; 5 I0; $585 ; 530 ; 53$ I; 654. H. 543; $5+4: 5+5$, I, II ; 600, II, I; $64+$.

Inflection: temptō; rēs; adfīrmāns : suī. 
Order of words: when a noun is modified by both an adjective and a genitive, the order often is adjective, genitive, noun, the precise arrangement being determined by emphasis.

Prescribed list:

$\begin{array}{llll}\text { postquam } & \text { redderent } & \text { hospitiō } & \text { adimit } \\ \text { lacrimae } & \text { concursus } & \text { adferō } & \text { inermēs } \\ \text { mānsit } & \text { generis } & \text { aliquis } & \text { bīnis }\end{array}$

\section{ALCO AND ALORCUS TRY TO BRING ABOUT PEACE THE SPEECH OF ALORCUS}

Temptāta deinde per dūōs est exigua ${ }^{1}$ pācis spēs, Alcōnem Saguntīnum et Alorcum Hispānum. Alcō, cum ad Hannibalem noctū trānsìsset, postquam nihil lacrimae movēbant, trānsfuga ex ōrātōre ${ }^{2}$ factus, apud hostem mānsit, eumº moritūrum esse adfīrmāns quī sub condiciōnibus iīs dẻ pāce ageret. Postulābātur autem redderent ${ }^{4}$ rēs Turdētānīs, ${ }^{5}$ trāditōque omnī aurō atque argentō, ēgressī urbe ibi habitārent ${ }^{6}$ ubi Poenus iussisset. Alorcus sē pācis eius interpretem fore pollicētur. Erat autem tum miles Hannibalis, sed püblicē Saguntinīs amīcus. Cum concursus omnis generis ${ }^{7}$ hominum esset factus, senātus Alorcō datus est, cuius tālis ōrātiō fuit: "Ego prō vetustōo ${ }^{8}$ hospitiō, quod mihi ${ }^{9}$ vōbīscum est, ad vōs vēnì. Neque dum vestrīs vīribus restitistis neque dum auxilia ab Rōmānìs spērāstis, pācis apud vōs mentiōnem fēcī. Postquam nec ab Rōmānìs vōbīs ùlla est spēs nec vestra vōs iam aut arma aut moenia ${ }^{10}$ satis dēfendunt, pācem adferō ad vōs magis necessāriam quam aequam. Cuius ${ }^{11}$ ita aliqua spēs est, si eam, quem ad modum ut victor fert ${ }^{12}$ Hannibal, sīc vōs ut victī audiētis. Urbem, quam captam ferē tōtam habet, adimit, agrōs relinquit. Aurum et argentum omne püblicum prīvātumque ad sē iubet dëferrï. Corpora vestra, coniugum, ac liberōrum vestrōrum servat inviolāta, sì inermēs cum bīnīs vestīmentīs velìtis ab Saguntō exīre. Haec victor hostis imperat; haec, quamquam sunt gravia, fortūna vestra vōbīs suādet. Equidem haud dēspērō, ${ }^{13}$ cum omnium potestās eĩ facta sit, aliquid ex hìs rēbus remissūrum." — Livy 


\section{VOCABULARY}

trānsfuga, ae, m., f., desertèr

morior, morī, mortuus, die

aurum, i, n., gold

argentum, $\overline{1}, \mathrm{n}$., siliter

urbs, urbis, f., city

interpres, etis, m., f., messenger

coniunx, ugis, m., f., husband, wife servō, I, preserve

vestimentum, ì, n., garment

suāđēo, 2, suāsī, suāsum, adriise

quamquam, although

equidem, indeed

haud, not

\section{NOTES}

1 exigua : synonym of parvus. 2 ōrātōre: ōrō + tor. English derivative? ${ }^{3}$ eum: that man. ${ }^{4}$ redderent: understand ut. ${ }^{5}$ Turdētānis : a tribe in southwestern Spain. ${ }^{6}$ habitārent: think of an English derivative with a prefix. $\quad{ }^{7}$ generis: genitive of quality. 8 vetustō: synonym of vetus. 9 mihi: dative of the possessor. Translate into English by the nominative case, and render est by the appropriate form of have. ${ }^{10}$ moenia: synonym of mūrus. ${ }^{11}$ cuius: its antecedent is pācem. ${ }^{12}$ fert: offêrs. 13 dēspērō : dē + spērō.

In the following phrases determine the reason for the position of each word: exigua pācis spēs; trāditō omnì aurō; pācis eius interpretem; concursus omnis generis hominum; vōbis ūlla est spēs.

\section{EXERCISE NXIV}

Grammar: A. 413; 53I; 537, I : 573:574. B. 222: 282, I : 284, I ; 300 , I. G. $392 ; 543$, I; 545, I: 452, $2 ; 467$. H. 473. I : 568: 570 ; 649. II.

Inflection: dēfendō; vīs ; magis (compare); ipse.

Order of words: a relative clause usually follows the clause which contains the antecedent of the relative.

Prescribed list:

$\begin{array}{llll}\text { priusquam } & \text { rettulērunt } & \text { peditum } & \text { marī } \\ \text { respondēo } & \text { summā } & \text { octingentī } & \text { sescentīs } \\ \text { aggressus } & \text { cōnsulerent } & \text { centum } & \text { comparātīs } \\ \text { praedā } & \text { ēvēnit } & \text { sexāgintā } & \text { dìmicātūrum } \\ \text { redierant } & \text { sēdecim } & \text { maritimus } & \end{array}$


THE FALI, OF SAGUNTUM ALARMS THE ROMANS AND AROUSES THEM TO GREATER ACTIVITY

Priusquam respōnsum ${ }^{1}$ darētur, tumultus ex arce auditur. Turris diū quassāta prōciderat, ${ }^{2}$ perque ruinam eius Hannibal tôtīs vīribus aggressus urbem mōmentō ${ }^{3}$ capit, ${ }^{4}$ signō datō ut omnēs pūberēs interficerentur. Captum oppidum est cum ingentī praedā. Sub idem ferē tempus et lēgātī, quī redierant ab Carthāgine, Rōmam rettulērunt omnia hostīlia ${ }^{5}$ esse, et Saguntī excidium nūntiātum est ; tantaque īra in Carthāginiēnsīs metusque ${ }^{6}$ dē summā rērum cêpit, ut animī turbātī timērent magis quam cōnsulerent. Nōminātae iam anteā cōnsulibus prōvinciae erant. ${ }^{7}$ Cornēliō $^{8}$ Hispānia, Semprōniō Āfrica cum Siciliā ēvēnit. Inter cōnsulēs ita cōpiae dīvîsae : Semprōniō datae legiōnēs duae et sociōrum sēdecim mỉia peditum, equitēs mīlle octingentī, nāvēs longae centum sexāgintā. Cum hìs terrestribus maritimīsque cōpiēs Tiberius Semprōnius in Siciliam missus est. Cornēliō minus cōpiārum datum est, quia Lūcius Manlius praetor ${ }^{9}$ et ipse cum haud invalidō ${ }^{10}$ praesidiō in Galliam mittēbātur. Nāvium maximē Cornēliō numerus dēminūtus est. Neque enim marī ventūrum aut eā parte bellì dỉmicātūrum hostem crēdēbant. I )atae sunt duae legiōnēs Rōmānae cum suō iūstō equitātū et quattuordecim milibus sociōrum peditum, equitibus mîlle sescentîs. Hīs ita comparātīs, ut omnia iūsta ante bellum fierent, lēgātōs in Āfricam mīsērunt ut cognōscerent pūblicōne ${ }^{11}$ cōnsiliō Hannibal Saguntum oppugnāvisset, et, sì id fatērentur ac dēfenderent, ut indīcerent populō Carthāginiēnsī bellum. — Lıvy

\section{VOCABULARY}

arx, arcis, f., citadel

quassō, I, shake

pūberēs, um, m., adults

ingēns, ingentis, enormous

excidium, exci'dī, n., downfall

ira, ae, f., wrath (ire)

turbō, 1, disturb (turbulent) terrestris, e, of the land haud, not, by no means dēminuō, 3, uī, ūtus, diminish crēdō, 3, didī, ditus, believe iūstus, a, um, appropriate fateor, 2, fassus, acknowledge indīcō, 3, dīxī, dictus, declare 
NOTES

1 respōnsum : a noun. $\quad 2$ prōciderat : prō + cadō. $\quad{ }^{3}$ mōmentō : English derivative? ${ }^{4}$ capit: historical present. ${ }^{5}$ hostīlia: hostis + ilis, belonging to. ${ }^{6}$ metus: synonym of timor. ${ }^{7}$ erant: with nōminātae. 8 Cornēilō: Scipio. ${ }^{9}$ praetor: one of the chief magistrates of Rome. 10 invalidõ: in + validus from valeō. $\quad 11$ pūblicōne: note the particle.

This passage contains clauses of purpose and of result. Do they follow or precede the verbs on which they depend? Which is an exception? Account for its position.

\section{EXERCISE XXV}

Grammar: A. 346, c: 419. a; 546:573; 574. B. 20 I, I, a; 227, I; $288, \mathrm{I}, \mathrm{B} ; 300,1$. G. 372 , R. 2 ; 409; $5 \mathrm{~S} 5 ; 452,2 ; 467$. H. 444 ; $489 ; 600, \mathrm{II}, \mathrm{I} ; 649$, II.

Inflection: volō; pater; pūblicus ; tü.

Order of words: indirect questions commonly follow the clause on which they depend.

Prescribed list:

$\begin{array}{llll}\text { postquam } & \text { utrum } & \text { auctōritāte } & \text { sūmite } \\ \text { mandātum erat } & \text { iūre } & \text { portāmus } & \text { iterum } \\ \text { quaesìvisset } & \text { licuerit } & & \end{array}$

\section{THE EMBASSY TO CARTHAGE DOES NOT AVERT THE WAR}

Rōmānī postquam Carthāginem vēnērunt, cum senātus datus esset et Quīntus Fabius lēgātus nihil quam ūnum quod mandātum erat quaesīvisset, tum ex Carthāginiēnsibus ūnus: "Ego nōn prīvātō pūblicōne cōnsiliō Saguntum oppugnātum sit quaerendum ${ }^{1}$ cēnseō, sed utrum iūre an iniūriā. Nostra enim haec quaestiō est, quid imperātor nostrō aut suō fēcerit arbitriō. Vōbisscum ūna disceptātiō est, licueritne per foedus fierī. Vōs quod Gāius Lutātius cōnsul prīmō nōbīscum foedus ${ }^{2}$ ícit, quia neque ex auctōritāte patrum nec populì iussū ictum erat, negāvistis vōs eō tenērī; itaque aliud de integro $\overline{0}^{3}$ foedus püblicō cōnsiliō ictum est. Sì vôs nōn 
tenent foedera vestra nisi ex auctōritāte aut iussū vestrō icta, nē nōs quidem ${ }^{4}$ Hasdrubalis foedus, quod nōbīs īnscīis ${ }^{5}{ }^{1}{ }^{1}{ }^{2}{ }^{6}{ }^{6}$ obligāre ${ }^{7}$ potuit. Omittite ${ }^{8}$ Saguntī atque Hibērī mentiōnem facere, et quod diū parturit animus vester aliquandō pariat." 9 Tum Rōmānus, sinū ex togā factô, “Hìc," inquit, "vōbīs bellum et pācem portāmus; utrum placet, sūmite." Tum succlāmātum ${ }^{10}$ est, daret ${ }^{11}$ utrum vellet. Et cum is, iterum sinū effūsō, bellum dare dīxisset. accipere sē omnēs respondērunt. - LIVY

\section{VOCABULARY}

cēnseō, 2, uī, us, be of opinion quaestio, ōnis, f., inquiry (question) arbitrium, arbi'trī, n., decision disceptātiō, ōnis, f., discussion foedus, eris, n., treaty icō, 3, ici, ictus, strike, (with foedus) make

quia, because negō, 1, say "no," deny" (negative) integer, gra, grum, fiesh parturiō, 4 , ivīi, — , desire to bring forth, meditate aliquandō, at length sinus, ūs, m., fold (sinuous) inquam (defective verb), say placeō, 2, uī, itum, please effundō, 3, fūdī, fūsus, empty

\section{NOTES}

${ }^{1}$ quaerendum : indirect discourse after cēnse⿳亠丷; ; the subject is the preceding clause. 2 foedus: placed in the relative clause for emphasis. Translate

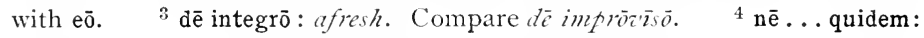
the emphatic word stands between. ${ }^{5}$ insciis : in + sciō. ${ }^{6}$ icit: subject refers to Hasdrubalis. ${ }^{7}$ obligāre : bind. ${ }^{8}$ omittite: English derivative? ${ }^{9}$ pariat: let it bring forth, a subjunctive of exhortation. ${ }^{10}$ succlāmātum: synonym of exclāmō. 11 daret: this was an imperative in the words of the Carthaginians.

Explain the derivation of quaestiō, imperātor, auctōritāte.
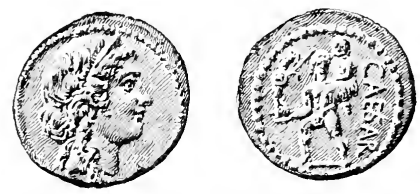

A ROMAN COIN 


\section{EXERCISE XXVI}

Grammar: A. 370 ; 413 ; 580; 584. B. 187, III ; 222; 314, I : $270,1, a, b, c ; 3 \mathrm{I} 7$. G. $347 ; 392 ; 650 ; 653 ; 531$. H. $429 ; 473$, I : $642 ; 643 ; 6$ I 7 .

Inflection: proficīscor; gladius; omnis ; quī.

Order of words: a relative pronoun often stands first in a sentence because its antecedent is in the preceding sentence.

Prescribed list:

$\begin{array}{llll}\text { servitūtis } & \text { praeter } & \text { vigiliā } & \text { rīpā } \\ \text { moram } & \text { vixdum } & \text { tergōo } & \text { dextrīs } \\ \text { loquī } & \text { occurreret } & \text { adoriātur } & \text { anceps } \\ \text { hospitem } & \text { àverteret } & \text { èditō } & \text { vīeōs } \\ \text { enim } & & & \end{array}$

HANNIBAL ON HIS MARCH TRIES TO CONCILIATE THE GAULS, BUT IS OPPOSED BY A POWERFLL TRIBE

Hannibal cum magnis cōpiìs P'ȳrēnaeum ${ }^{1}$ trānsgreditur et castra pōnit. Gallì, quamquam İtaliae ${ }^{2}$ bellum inferrì audiēbant, tamen quia fāma ${ }^{3}$ erat Hispānōs trāns P̄̄̀rēnaeum vī subāctōs esse, metū ${ }^{4}$ servitūtis ad arma cōnsternāti $\overline{1}^{5}$ conveniunt. Quod ubi Hannibalī nūntiātum est, moram magis quam bellum metuēns ${ }^{6}$ ōrătōrēs ${ }^{7}$ ad eōs mīsit, loquī sē cum iiss velle, et acceptūrum eōs in castra sua; hospitem ${ }^{8}$ enim sē Galliae, nōn hostem vēnisse, nec strictūrum esse gladium, sī per Gallōs licēret, antequam ${ }^{9}$ in İtaliam vēnisset. Interim Pūblius Cornēlius, dux Rōmānus, profectus ab urbe sexāgintā longīs nāvibus praeter ōram Etrūriae ${ }^{10}$ pervenit Massiliam ${ }^{11}$ et castra pōnit, vixdum satis crēēens Hannibalem superāvisse P'ỳrēenaeôs montīs. Quem ut dē Rhodanī quoque trānsitūìn agitāe cognōvit, incertus in quō locō eĩ occurreret, trecentōs equitēs ad explōranda omnia praemittit. Hannibal iam in Volcārum pervēnerat agrum, gentis validae. ${ }^{13}$ Ingēns vīs nāvium coācta est. (Omnibus rēbus satis comparātīs ad trāiciendum ${ }^{14}$ terrēbant ex adversō hostēs. Quōs ut āverteret Hannibal Hannōnem vigiliā prīmā noctis cum 
parte côpiārum adversō flūmine ìre iter ūnīus diēī iubet et trāiectō flūmine circumdūcere agmen ut hostīs à tergōo adoriātur. Posterō diē profectī ex locō èditō fümō significant trānsīsse et haud procul ${ }^{1.5}$ abesse. Quod ubi accēpit, Hannibal nāvibus lintribusque cōpiās flūmen trādūcit. Gallī occursant in rīpā, quatientēs scūta super capita, vibrantēs dextrīs tēla. Mox et ${ }^{16}$ ipse Hannō aderat, anceps terror circumstābat. Gallī perrumpunt et in vìcōs suōs diffugiunt. ${ }^{1 \overline{1}}$ - L Livy

\section{VOCABULARY}

trānsgredior, 3, gressus, cross

quamquam, although

quia, because

subigō, 3, ēgī, āctus, compel

stringō, 3 , strīnxī, strictus, draw

ora, ae, f., coast

crēdō, 3, didī, ditus, beliea'e (credible)

gēns, gentis, f., tribe

ingēns, ingentis, lluge

terrē̄, 2, uī, itus, alarm

fümus, $\overline{1}, \mathrm{~m} .$, smoke (fume) linter, tris, f., skiff

occursō, I, oppose

quatiō, 3, - quassus, shake super, aboz'e

vibrō, I, brandish (vibrate)

mox, presently

circumstō, I. stetī, —_, stand around

perrumpō, 3, rūpî, ruptus, break through

\section{NOTES}

1 Fỹrēnaeum: the Pyrenees mountains. 2 İtaliae: for the case, consider inferrī. ' fâma: synonym of rūmor. English derivative? ${ }^{4}$ metū: synonym of timor. $\quad{ }^{5}$ cōnsternātī: synonym of commoveō. $\quad{ }^{6}$ metuēns : compare metū above. Tōrātōrēs: ōrō + tor, intercessors. The following indirect discourse depends upon the idea of saying implied in this word. ${ }^{8}$ hospitem: contrasted with hostem. Notice the emphasis. ${ }^{9}$ antequam: synonym of priusquam. ${ }^{10}$ Etrūriae: northwest of Rome. ${ }^{11}$ Massiliam : Narseilles. ${ }^{12}$ trānsitū: trāns + eō t tus, act of. ${ }^{13}$ validae: derived from the verb valeō. ${ }^{14}$ trāiciendum : trāns + iaciō. ${ }^{15}$ haud procul : $b y$ no means far. ${ }^{16}$ et: also. ${ }^{17}$ diffugiunt: dis + fugiō. 


\section{EXERCISE XXVII}

Grammar: A. $208, d: 418: 452,1: 531,2$. 13. 256, 3: 226: 329 ; $330 ; 282,2$. G. 208,$2 ; 397: 422 ; 630$. H. 302,6; 4 SO; 61 5, $1 ; 590$.

Inflection: pōnō; animal; inferior; quis.

Order of words: clauses of purpose and result commonly follow the clause on which they depend.

\section{Prescribed list:}

$\begin{array}{llll}\text { quīngentōs } & \text { via } & \text { prope } & \text { regiōne } \\ \text { trecentī } & \text { quārtīs } & \text { inde } & \text { propinquō } \\ \text { occurrunt } & \text { incolunt } & \text { inferior } & \text { renovāvērunt }\end{array}$

HANNIBAL ADVANCES TOWARD TIE PASSAGE OF TIIE ALI'S

Hannibal Numidās equitēs quīngentōs ad castra Rōmāna mīserat, quī cognōscerent ubi et quantae cōpiae essent et quid parārent. Huic ālae equitum treçentī Rōmānōrum equitēs occurrunt. Ācriter pugnātum est. Fuga Numidārum Rōmānis victōriam dedit. Ré ita gestā, Hannibal Ītaliam petere cōnstituit. Profectus adversā rīpā Rhodanī mediterrānea Galliae petit, nōn quia rēctior ad Alpīs via esset, sed quia cum Rōmānīs, priusquam in İtaliam vēnisset, nōn erat in animō proelium committere. Quārtīs castrīs ad ìnsulam pervēnit. Incolunt prope Allobrogēēs, gēns iam inde nūllā Gallicā gente ${ }^{1}$ opibus aut fāma $\overline{2}^{2}$ inferior. Cum iam Alpìs Hannibal peteret, nōn rēctā regiōne ${ }^{3}$ iter instituit, sed ad laevam ${ }^{4}$ in Tricastīnōs flexit. Inde Alpiss pervēnit. Tum ex propinquō vìsa montium altitūdō nivēsque caelō prope immixtae, hominēs intōnsì et incultī, animālia inanimaque omnia rigentia gelū, terrōrem renovāvērunt. Hannibal cōnsistere signa iussit. Gallis ad visenda loca praemissīs, castra pōnit. — LIVY

\section{VOCABULARY}

āla, ae, f., squadron

mediterrānea, ōrum, n., interior

quia, because rēctus, a, um, straight (rectify')

gēns, gentis, f., tribe

(ops), opis, f., resources 
flectō, 3, flexī, flexus, tum

nix, nivis, f., snow'

caelum, $\overline{1}, \mathrm{n} . .$, sky

intōnsus, a, um, rude

incultus, a, um, wild inanimus, a, um, lifeless (inanimate) rigeō, 2, uī, - _., be stiff (rigid)

gelū, ùs, n., cold (congeal)

vīsō, 3, vīsī, vìsus, look at

\section{NOTES}

${ }^{1}$ gente: for the case, consider inferior. ${ }^{2}$ fāmā: English derivative? ${ }^{3}$ regiōne: direction. ${ }^{4}$ laevam: synonym of sinister.

Explain the derivation of pervēnit, altitūdō, inanima, praemissīs.

\section{EXERCISE XXVIII}

Grammar: A. $346, a, 3: 405$, N. 3: 424. a: 537, N. 2. B. 201,2 ; 2I6. I: I8I, $2 ; 284$ I. G. $372 ; 40$ I, R. $2: 336: 552$, end. H. +42 ; 468, I : 4I7, I; 570.

Inflection: mālō; saxum : alius; ipse.

Order of words: in a phrase the emphatic word usually stands first.

Prescribed list:

$\begin{array}{llll}\text { lüce } & \text { inde } & \text { insidī̄s } & \text { undique } \\ \text { castellīs } & \text { cibō } & \text { experīī } & \text { fronte } \\ \text { simul } & \text { pecoribus } & \text { temerē } & \text { tergō } \\ \text { vulnerātī } & \text { apertō } & \text { rōbore } & \text { coortī }\end{array}$

HANNIBAL ATTEMPTS THE CROSSING OF THE ALPS, BUT IS ATTACKED BY THE MOUNTAINEERS

Prīmā deinde lūce castra mōvit. Montānī signō datō ex castellīs conveniēbant. Tum vērō simul ab hostibus, simul ab inīquitāte ${ }^{1}$ locôrum Poenì oppugnābantur. Equì maximē īnfēstum agmen faciēbant, quī territî trepidābant et ictī forte aut vulnerātī adēō cōnsternābantur ut strāgem ingentem simul hominum ac sarcinārum omnis generis² facerent. Stetit parumper Hannibal ac suōs continuit, nè tumultum ac trepidātiōnem ${ }^{3}$ augēret. Castellum inde, quod caput eius regiōnis erat, vīculōsque circumiectōs cēpit, et captìvo ${ }^{4}$ cibō ac pecoribus per trīduum exercitum aluit. Perventum 
inde est ad alium populum. Ibi nōn bellō apertō, sed fraude ${ }^{5}$ et insidiīs est prope circumventus. Prīncipēs castellōrum ōrātōrēs ${ }^{6}$ ad Poenum veniunt memorantēs ${ }^{\top}$ amícitiam mālle quam vim experīrī Poenōrum ; itaque imperāta factūrōs esse. Hannibal nec temerē crēdendum $^{8}$ ratus, $^{9}$ benignē cum respondisset, obsidibus quōs dabant acceptīs et commeātū quem in viam ipsī dētulerant ūsus, nēquāquam ut inter pācātōs, compositōo ${ }^{10}$ agmine, ducēs eōrum sequitur. Prīmum agmen elephantī et equitēs erant; ipse post cum rōbore peditum incēdēbat. ${ }^{11}$ Ubi in angustiōrem viam vēnērunt, undique ex insidiīs barbarī ā fronte, ab tergō coortī comminus ēminus petunt, ${ }^{12}$ saxa ingentia in agmen dēvolvunt. Tunc quoque ad extrēmum perīculī ac prope perniciem vēnērunt. - Livy

\section{VOCABULARY}

montānus, $\overline{1}, \mathrm{~m}$. , mountaineer infēstus, a, um, unsafe terreō, 2, uī, itus, frighten trepidō, $\mathrm{I}$, be in alarm ìcō, 3, ìi, ictus, strike forte, by chance adeō, to such a degree cōnsternō, i, terrify strāgēs, is, f., destruction ingēns, ingentis, lluge sarcinae, ārum, f., packs stō, I, stetī, statum, stand parumper, for a little while tumultus, ùs, m., uprising vīculus, i, m., hamlet alō, 3 , uī, tus or itus, feced mālō, mālle, māluī, —_ prefìr. crēdō, 3, didī, ditus, belie'َ'e (creed) benignē, in a kindly way nēquāquam, by no means comminus, hand to hand ēminus, fiom a distance dēvolvō, 3, volvī, volūtus, roll down perniciēs, è̄ì, f., ruin (pernicious)

\section{NOTES}

1 inīquitāte: in + aequus + tās. ${ }^{2}$ generis: shows quality. ${ }^{3}$ trepidātiōnem: trepidō + tiō. $\quad{ }^{4}$ captivō : captured. ${ }^{5}$ fraude : English derivative? ${ }^{6}$ ōrātōrēes: ōrō + tor. $\quad{ }^{7}$ memorantēs: = dīcentēs. ${ }^{8}$ crēdendum: understand esse. The subject refers to the preceding statement. ${ }^{9}$ ratus : participle of reor, a synonym of putō. $\quad{ }^{10}$ compositō: con + pōnō. $\quad{ }^{11}$ incēdēbat: = prōcēdēbat. $\quad{ }^{12}$ petunt: attack.

Select phrases from the passage and note the emphasis expressed by the arrangement of the words in each phrase. 


\section{EXERCISE XXIX}

Grammar: A. $293 ; 423,2 ; 579 ; 580 ; 584$. B. 24I, I; I8I, I; 313 ; 314,$1 ; 317$. G. 291 , R. $2 ; 336 ; 648 ; 650 ; 653$. H. 497,$4 ; 417$; $641 ; 642 ; 643 ; 644$.

Inflection: iubeō; pedes; lātē (compare): quisquam.

Order of words: words are arranged in clauses or sentences in the order of their importance in the mind of the writer.

\section{Prescribed list:}

$\begin{array}{llll}\text { cunctātur } & \text { nōnō } & \text { unde } & \text { praeceps } \\ \text { angustiās } & \text { iugum } & \text { cōnsistere } & \text { mēnse } \\ \text { praesidiō } & \text { bīduum } & \text { modo } & \text { cōnstat } \\ \text { peditibus } & \text { quōdam } & \text { prōcēdere } & \end{array}$

IIANNIBAL REACIES TIIE SUMAIT OF THE ALPS ANI) I)ESCENDS INTO ITALY

Dum cunctātur ${ }^{1}$ Hannibal dēmittere ${ }^{2}$ agmen in angustiās, quia ${ }^{3}$ nōn, ut ipse equitibus praesidiō erat, ita peditibus quicquam ab tergō auxili reliquī erat, montānī ${ }^{4}$ per obliqua ${ }^{5}$ occursantēs, interruptō mediō agmine, viam insēdēre, noxque ūna Hannibalī sine equitibus atque impedīmentīs ācta est. Nōnō diē in iugum Alpium pervēnērunt. Bìduum in iugō statīva habita, ${ }^{6}$ fessīsque ${ }^{7}$ labōre ac pugnando quiēs data est mîlitibus. Hannibal praegressus signa in prōmunturiō quōdam, unde longē ac lātē prōspectus erat, cōnsistere iussīs mīlitibus İtaliam ostentat et dīcit eōs moenia ${ }^{8}$ tum trānscendere nōn Îtaliae modo sed etiam urbis Rōmānae; ūnō proeliō arcem et caput İtaliae in manū ac potestāte cōs habitūrōs esse. Prōcēlere inde agmen coepit. Omnis ferē via praeceps, angusta erat, ut sustinēre sē à lāpsū nōn possent. Hōc modō in İtaliam perventum est, quīntō mēnse à Carthāgine Novā, ${ }^{9}$ ut quỉdam auctōrēs sunt, quintō decimō diē Alpibus superātìs. Quantae cōpiae Iannibalī ${ }^{10}$ fuerint, nēquāquam inter auctōrēs cōnstat. Quī plūrimum, centum mìlia peditum, vìgintī equitum fuisse scrībunt; quīî minimum, vịgintỉ milia peditum, sex equitum. - Livy 


\section{VOCABULARY}

occursō, I, rush against

insideō, 2, sēđī, sessus, occupy

stativa, ōrum, n., stationary camp

praegredior, 3, gressus, adrance

trānscendō, 3 , scenđī, scēnsus, climb arx, arcis, f., citadel

lāpsus, ūs, m., slipping (relapse) auctor, öris, m.. author, writer nēquāquam, by no means scrībō, 3, scrīpsī, scrīptus, write ocer

\section{NOTES}

1 cunctātur: dum, while, is regularly followed by the present indicative. What tense is required in the translation? ${ }^{2}$ demmittere: for the meaning, observe the composition. $\quad{ }^{3}$ quia: = quod. $\quad{ }^{4}$ montānī: mōns + ānus, pertaining to. ${ }^{5}$ per obliqua: used adverbially. Compare dē imprōvisō. $\quad{ }^{6}$ habita: supply sunt. ${ }^{7}$ fessis : = dēfessīs. ${ }^{8}$ moenia : referring to the Alps. $\quad{ }^{9}$ Carthāgine Novä: a city in Spain. ${ }^{10}$ Hannibali : dative of the possessor. Translate it as the subject of the appropriate form of the verb have. ${ }^{11}$ qui : understand scribunt.

Explain the derivation of potestāte, sustinēre, auctōrēs.

\section{EXERCISE XXX}

Grammar: A. 374, a; 375; 406; +12; 504. B. I89, I, 2 : 217 , I ; $220, \mathrm{I} ; 338, \mathrm{I}$, a. G. $35+; 355 ; 398 ; 399: 428$. H. 431, 2; 47I; $+73,3 ; 626$.

Inflection: ferō; nāvis; habēns; ego.

Order of words: the beginning of the sentence is usually the place of emphasis.

Prescribed list:

$\begin{array}{llll}\text { locūtus esse } & \text { occurristis } & \text { quōcumque } & \text { statuit } \\ \text { dextrā } & \text { imposuit } & \text { rōboris } & \text { potius } \\ \text { maria } & \text { praemia } & \text { praetereā } & \text { iterum } \\ \text { urgent } & \text { aestāte } & \text { superbissima } & \end{array}$

AFTER DESCENDING THE ALPS INTO ITALI HANNIBAL ADDRESSES HIS SOLDIERS

Cōntiōne inde advocātā ${ }^{1}$ ita apud mìlitēs Hannibal locūtus esse fertur": "Dextrā laevāque ${ }^{3}$ duo maria claudunt nūllam nē ad effugium ${ }^{4}$ quidem nāvem nōs habentīs ; $\operatorname{circā~}^{5}$ Padus flūmen, Padus 
maior ac violentior ${ }^{6}$ Rhodanō, ab tergō Alpēs urgent, vix integrīs vōbīs trānsitae. $\mathrm{Hìc}^{\bar{\gamma}}$ vincendum ${ }^{8}$ aut moriendum, mīlitēs, est, ubi prīmum hostī occurristis. Et eadem fortūna quae necessitātem pugnandì imposuit, ea ${ }^{9}$ praemia vōbīs victōribus prōpōnit quibus ${ }^{10}$ ampliōra hominēs nē ab deis quidem immortālibus optāre ${ }^{11}$ solent. Hìc vỏbīs terminum labōrum fortūna dedit. Pugnābitis cum exercitū tīrōne, hāc ipsā aestāte victō ā Gallìs. Quōcumque circumtulī oculōs, ${ }^{12}$ plēna omnia videō animōrum ac rōboris, veterānum peditem, generōsissimārum gentium equitēs, vōs sociōs fidēlissimōs ${ }^{13}$ fortissimōsque, vōs, Carthāginiēnsēs, cum prō patriā tum ob ìram iūstissimam pugnātūrōs. İnferimus bellum infēstìsque signīs dēscendimus in Italiam. Accendit ${ }^{1+}$ praetereā et stimulat animōs dolor ${ }^{15}{ }^{15}$ iniūria, indignitās. Crūdēlissima ac superbissima gēns sua ${ }^{16}$ omnia facit. Circumscrībit inclūditque ${ }^{1 \bar{\tau}}$ nōs terminīs montium flūminumque quōs nōn excēdāmus, neque eōs quōs statuit terminōs observat. I uuoss cōnsulēs huius annī, ūnum in Âfricam, alterum in Hispāniam mīsērunt. Nihil ūsquam nōbìs relictum est nisi quod armìs vindicāverimus. Vōbīs necesse est fortibus virìs esse et aut vincere, aut, sì fortūna dubitābit, in proeliō potius quam in fugā mortem oppetere. ${ }^{18}$ Sì hoc bene fīxum omnibus est, iterum dīcam, vìcistis. Nüllum ācrius contempt $\bar{u}^{19}$ mortis tēlum ad vincendum hominī ab deìs immortālibus datum est." - Lıvy

\section{VOCABULARY}

cōntiō, ōnis, m., assembly claudō, 3, clausì, clausus, shut in integer, gra, grum, fresh morior, mori, mortuus, die deus, i, m., god soleō, 2, solitus, be accustomed tīō, ōnis, m., recruit: as adj., newly levied

plënus, a, um, full (plenty)

generōsus, a, um, excellent gēns, gentis, f., tribe ira, ae, f., wrath (irate)

infēstus, a, um, hostile

accendō, 3. dì, accēnsus, kindle crūđēlis, e, cruel

circumscrībō, 3, scrīpsī, scrīptus, confine

ùsquam, anyallere

vindicō, I, defend

necesse (indeclinable), necessary fīgō, 3, fīxi, fixus, establis/ 


\section{NOTES}

${ }^{1}$ advocātā: notice the composition. $\quad{ }^{2}$ fertur: is said. $\quad{ }^{3}$ laevā: synonym of sinister. $\quad{ }^{4}$ effugium : ex + fugiō + ium, act of. $\quad{ }^{5}$ circã : adverb, synonymous with circum. ${ }^{6}$ violentior: vīs + lentus, full of. ${ }^{7}$ hic: adverb. $\quad 8$ vincendum: understand vōbis. ${ }^{9}$ ea: subject of prōpōnit. ${ }^{10}$ quibus : depends on ampliōra. $\quad{ }^{11}$ optāre : synonym of volō. ${ }^{12}$ oculōs : English derivative "oculist." ${ }^{13}$ fidēlissimōs: fidēs + lis, fütainins to. Compare "fidelity." ${ }^{1+}$ accendit: notice the order of the words in the sentence. ${ }^{15}$ dolor: doleō + or, act of. ${ }^{16}$ sua: predicate adjective, its ozin. 17 inclūdit: in + claudō. 18 oppetere: meit. 19 contemptū : depends on ācrius.

Think of English words from maria, nāvem, urgent, occurristis, patria, circumscrībit, vincere.

\section{EXERCISE XXXI}

Grammar: A. +14; +1S; 504: 537. N. 2. B. 223: 226: 33 S, I, a ; 2S4. I. G. 403: 397; 428; 552, end. H. 479. I; 4So; 626; 570.

Inflection: pellō; virtūs: superus (compare); quī.

Order of words: demonstrative pronouns and adjectives of quantity tend to precede the nouns which they modify.

Prescribed list:

$\begin{array}{llll}\text { nēmō } & \text { nisi } & \text { prius } & \text { reddidit } \\ \text { praestitisse } & \text { velut } & \text { aliēnārum } & \text { potentissimus } \\ \text { congressus est } & \text { sìc } & \text { dēstiterit } & \text { incendit }\end{array}$

THE CHARACTER OF HANNIBAL AND HIS HATRED

OF ROME

Hannibal, ${ }^{1}$ Hamilcaris fïlius, Carthāginiēnnsis. Sī vērum est, quod nēmō dubitat, ut populus Rōmānus omnīs gentīs virtūte superārit, nōn est înfitiandum Hannibalem tantō ${ }^{2}$ praestitisse cēterōs ${ }^{3}$ imperātōrēs prüdentiā, quantō populus Rōmānus antecēdat ${ }^{4}$ fortitūdine $^{j}$ cūnctās ${ }^{6}$ nātiōnēs. Nam quotiēnscumque cum eō ${ }^{\overline{7}}$ congressus est in İtaliā, semper discessit superior. Quod ${ }^{8}$ nisi domī cìvium ${ }^{9}$ suōrum invidiā dēbilitātus esset, Rōmānōs vidētur superāre potuisse. Hìc autem velut hērēditāte relictum odium paternum ergā Rōmānōs sìc cōnservāvit ut prius ${ }^{10}$ animam quam id dēposuerit, qui quidem, 
cum patriā pulsus esset et aliēnārum opum ${ }^{11}$ indigēret, numquam dēstiterit animō bellāre cum Rōmānīs. Nam ut omittam Philippum, quem absēns ${ }^{12}$ hostem reddidit Rōmānìs, omnium iīs temporibus potentissimus rēx Antiochus fuit. Hunc tantā cupiditāte ${ }^{13}$ incendit bellandī ut ūsque ā rubrō marī arma cōnātus sit īnferre İtaliae.

Nepos

\section{VOCABULARY}

gëns, gentis, f., tribe

infitior, I, deny

quotiēnscumque, as often as

semper, always

invidia, ae, f., jealousy

dēbilitō, I, weakin (debility)

hērēditās, ātis, f., inlueritance

odium, odi, n., hatred (odious)

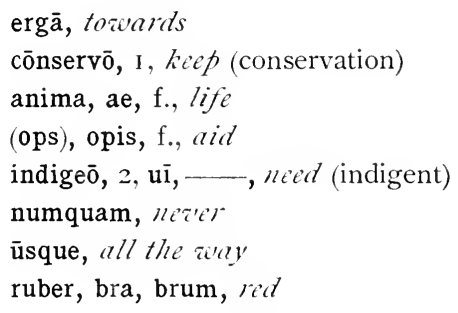

\section{NOTES}

${ }^{1}$ Hannibal: the verb is understood. ${ }^{2}$ tantō: degree of difference. ${ }^{3}$ cēterōs: synonym of reliquī. $\quad{ }^{4}$ antecēdat: ante + cēdō. $\quad{ }^{5}$ fortitūdine : fortis + tūdō. $\quad{ }^{6}$ cūnctās : synonym of omnis. $\quad{ }^{7}$ eō: i. e. populō Rōmānō. ${ }^{8}$ quod: therefore. $\quad{ }^{9}$ cìvium: cīvitās is formed from the stem. $\quad{ }^{10}$ prius : sooner. 11 opum: depends on indigēret. ${ }^{12}$ absēns: he was in Italy at the time. $\quad{ }^{13}$ cupiditāte: cupidus + tās.

Observe the words in this passage nearly identical with English words: prūdentiā, fortitūdine, nātiōnēs, superior, odium, paternum, omittam, absēns, and others.

\section{EXERCISE XXXII}

Grammar: A. +I 5; +19, a; 573; 580, c. B. 224; 227, 1; 300, I. G. $400 ; 409 ; 452,2 ; 423$, N. 5 . H. 473,$2 ; 489 ; 649$, II.

Inflection: quaerō; annus; tenēns: hīc.

Order of words: in a phrase the emphatic word usually stands first. Prescribed list:

$\begin{array}{llll}\text { nătō } & \text { fidem } & \text { īnstituerat } & \text { dēbeat } \\ \text { quaesīvit } & \text { postulō } & \text { iūrāre } & \text { quīn } \\ \text { libenter } & \text { simul } & \text { iūsiūrandum } & \text { cēlāris }\end{array}$


HANNIBAL'S SPEECII TO ANTIOCHUS ABOUT IIS OATH OF IHATRE TO THE ROMANS

Pater meus Hamilcar, puerulōo ${ }^{1}$ mē, utpote nōn amplius novem annōs ${ }^{2}$ nātō, in Hispāniam ${ }^{3}$ imperātor proficīscēns Carthāgine, Iovì optimō maximō hostiās immolāvit. Quae dīvina rēs ${ }^{4}$ dum cōnficiēbātur, quaesīvit ā mē vellemne sēcum in castra proficīscì. Id cum libenter accēpissem atque ab eō petere coepissem nē dubitāret dūcere, tum ille, "Faciam," inquit," "sì mihi fidem quam posiulō dederis." Simul mē ad āram addūxit apud quam sacrificāre instituerat, eamque cēterīs ${ }^{6}$ remōtīs tenentem ${ }^{7}$ iūrāre iussit numquam mē in amīitiā cum Rōmānīs fore. Id ego iūsiūrandum patrī datum ūsque ad hanc aetātem ita cōnservāvī ut nēminì dubium esse dēbeat quīn reliquó tempore eādem mente sim futūrus. ${ }^{8}$ Quārē sī quid amicē dē Rõmānīs cōgitābis, nōn imprūdenter fēceris sī mē cēlāris ${ }^{9}$; cum quidem bellum parābis, tē ipsum frūstrāberis sĩ nōn mē in eō prīncipem posueris. - NEPos

\section{VOCABULARY}

utpote, as, inasmuith as

hostia, ae, f., ricitim

immolō, I, sacrifice

inquam (defective verb), say

āra, ae, f., altar

numquam, nerer

ùsque, all the time aetās, ātis, f., time of life

cōnservō, I, liectp

dubius, a, um, doubtful

mēns, mentis, f., mind (mental)

cōgitō, 1, plan

frūstror, I, disappoint

\section{NOTES}

${ }^{1}$ puerulō: puer + ulus, little. 2 annōs : regularly after amplius, though the ablative is the rule after a comparative. ${ }^{3}$ Hispāniam: Spain, where the Second Punic War started. " ${ }^{5}$ inquit : regularly inserted after one or more words of a direct quotation. ${ }^{6}$ cēterīs: synonym of reliquī. ${ }^{7}$ tenentem: understand mē. ${ }^{8}$ sim futurus: this form expresses future time in the subjunctive mood. The subjunctive is used after quīn. ${ }^{9}$ cēlāris : what letters are omitted?

Explain the derivation of imperātor, amīcitiā. 


\section{EXERCISE XXXII}

Grammar: A. 370 ; 400; 423, I ; 568. B. 187 , III ; 214, 2; 231 ; 297 , I. G. $347 ; 390,2 ; 393 ; 553,1$. H. $429 ; 464 ; 486 ; 566$.

Inflection: ēo ; equitātus; factus : is.

Order of words: prepositional phrases usually precede the word which they limit, and are arranged according to the emphasis put on them.

Prescribed list:

praefuit

summam

dētulit

pūblicē sīc

comparāvit

frātre

quācumque nēmō

nisi

praeter

concīdit effēcit inermis

vix

saucium

IIANNIBAL'S SUCCESS WITH HOSTILE TRIBES BEFORE IIE REACIIES ITALY

Hāc igitur ${ }^{1}$ aetāte $^{2}$ cum patre in Hispāniam profectus est ${ }^{3}$; cuius post obitum, ${ }^{4}$ Hasdrubale imperātōre suffectō, equitātuī omnī praefuit. Hōc quoque interfectō, exercitus summam imperī ad eum dētulit. Id Carthāginem dēlātum pūblice $\bar{e}^{j}$ comprobātum est. ${ }^{6}$ Sīc Hannibal minor quīnque et vìgintī annīs ${ }^{7}$ nātus imperātor ${ }^{8}$ factus, proximō trienniō ${ }^{9}$ omnīs gentīs Hispāniae bellō subēgit, Saguntum, foederātam ${ }^{10}$ cìvitātem, vī expugnāvit, trīs exercitūs maximōos comparāvit. Ex hīs ūnum in Âfricam mīsit, alterum cum Hasdrubale frātre in Hispāniā reliquit, tertium in İtaliam sēcum dūxit. Saltum Pȳrēnaeum trānsiit. O Quācumque iter fécit, cum omnibus incolīs ${ }^{11}$ cōnflixit ${ }^{12}$; nēminem nisi victum dìmisit. Ad Alpis postquam vēnit, quae İtaliam ab Galliā sēiungunt, ${ }^{13}$ quās nēmō umquam cum exercitū ante eum praeter Herculem Grāium trānsierat, Alpicōs ${ }^{14}$ cōnantīs prohibēre trānsitū ${ }^{1 \bar{j}}$ concìdit, loca patefēeit, ${ }^{16}$ itinera mūniit, effēcit ut e ē ${ }^{17}$ elephantus örnātus ${ }^{18} \overline{1} 1$ e posset quā anteā ${ }^{19}$ ūnus homō inermis vix poterat rēpere. Hàc cōpiās trādūxit in Îtaliamque pervēnit. Pugnāverat apud Rhodanum cum Pūbliō Cornēliō Scipiōne cōnsule eumque pepulerat. Cum hōc eōdem apud Padum ${ }^{20}$ dimicat sauciumque inde ac fugātum ${ }^{21}$ dimittit. — NEPOS 


\section{VOCABULARY}

aetās, ātis, f., time of life

sufficiō, 3 , fēcī, fectus, put in place of gēns, gentis, f., tribe (gentile)

subigō, 3, ēgī, āctus, subclue saltus, ūs, m., mountain pass

umquam, $\tau^{\prime} \epsilon^{\prime}{ }^{\prime}$

örnō, I, equip

rēpō, 3 , rēpsī, —

\section{NOTES}

1 igitur: = itaque. $\quad{ }^{2}$ aetāte: i. e. novem annōs nātus. $\quad{ }^{3}$ profectus est: subject refers to IIannibal. ${ }^{4}$ obitum: synonym of mors. ${ }^{5}$ pūblicē : i. e. by the government, in spite of his youth. ${ }^{6}$ comprobātum est: con + probō. ' 7 annis: for the case, consider minor. 8 imperātor: in the predicate with factus. ${ }^{9}$ trienniō: trēs + annus. ${ }^{10}$ foederātam: allied. 11 incolis: noun from the verb incolō. 12 conflixit: synonym of pugnō. ${ }^{13}$ sēiungunt: sē, dis-, + iungō. $\quad{ }^{1+}$ Alpicōs: dwellers in the Alps. $\quad{ }^{15}$ trānsitū : trāns + eō + tus. $\quad{ }^{16}$ patefēecit: pateō + faciō. $\quad{ }^{17}$ eā: understand viā. ${ }^{18}$ ōnātus: contrasted with inermis below. ${ }^{19}$ anteā: opposite of posteā. 2) Padum: the Po river. ${ }^{21}$ fugātum: routed.

\section{EXERCISE XXXIV}

Grammar: A. 452, 1; 509: 510; 531, a. B. 329; 330; 340, 1, 2; 282, I, a. G. $+22 ;+35 ; 436 ; 5+5,2$. H. 609, I; 633;635; $568,7$.

Inflection: possum; aciēs; uterque; quî.

Order of words: an appositive regularly follows the noun which it limits.

\section{Prescribed list:}

$\begin{array}{llll}\text { dextrō } & \text { aliquot } & \text { cupīvit } & \text { simul } \\ \text { aeque } & \text { praetereā } & \text { valentior } & \text { excesserant } \\ \text { premerētur } & \text { restitit } & \text { congrederētur } & \text { contrāxit } \\ \text { hinc } & \text { iterum } & \text { bīduōo } & \end{array}$

HANNIBAL DEFEATS THE ROMANS BOTH IN ITALY AND

IN AFRICA

Per Ligurēs ${ }^{1}$ Appennīnum trānsiit, petēns Etrūriam. Hōc in itinere adeō gravī morbō afficitur ${ }^{2}$ oculōrum ut posteā numquam dextrō aequē bene ūsus sit. Quã valētūdine ${ }^{3}$ cum etiamtum 
premerētur lectīcāque ferrētur, Gāium Flāminium cōnsulem apud 'Trasumēnum ${ }^{4}$ cum exercitū insidiis circumventum occidit, ${ }^{j}$ neque multō post ${ }^{6}$ Gāium Centēnium praetōrem cum dēlēctā manū saltūs occupantem. Hinc in Āpūliam ${ }^{7}$ pervēnit. Ibi obviam è̃ vēnērunt $^{8}$ duo cōnsulēs, Gāius Terentius et Lūcius Aemilius. Utrīusque exercitūs ūnō proeliō fugāvit, Paulum cōnsulem occīdit et aliquot praetereā cōnsulārīs, in iīs Gnaeum Servìlium Geminum, quī superiōre annō fuerat cōnsul. Longum est omnia ēnumerāre ${ }^{9}$ proelia. Quamdiū in İtaliā fuit, nēmō eĩ in aciē restitit, nēmōo adversus eum post Cannēnsem ${ }^{10}$ pugnam in campō castra posuit. Hinc invictus ${ }^{11}$ patriam dēfēnsum ${ }^{12}$ revocātus bellum gessit adversus Pūblium Scīpiōnem, fĩlium eius Scīpiōnis quem ipse prīmō apud Rhodanum, iterum apud Padum, ${ }^{13}$ tertiō apud Trebiam ${ }^{1+}$ fugārat. Cum hōc, exhaustīs iam patriae facultātibus, cupìvit impraesentiārum bellum compōnere, quō valentior posteā congrederētur. In colloquium convēnit ${ }^{15}$; condiciōnēs nōn convēnērunt. Post id factum paucīs diēbus apud Zamam ${ }^{16}$ cum eōdem cōnflīxit ${ }^{17}$; pulsus (incrēdibile dictū) bìdūo et duābus noctibus Hadrūmētum pervēnit, quod abest ab Zamā circiter mìlia passuum trecenta. In hāc fugā Numidae, quī simul cum eō ex aciē excesserant, insidiātī sunt ${ }^{18}$ eì ; quōs nōn sōlum effügit ${ }^{19}$ sed etiam ipsōs oppressit. Hadrūmētī reliquōs è fugā collēgit; novīs dìlēctibus paucīs diēbus multōs contrāxit. - NEPOs

\section{VOCABULARY}

adeō, so

morbus, i, m., dise'usc' (morbid)

oculus, i, m., ev'e (ocular)

numquam, nerer

lectica, ae, f., litter

saltus, ūs, m.. mountain pass

fugō, I, fut to flisht

cōnsuläris, is, m., c $x^{-i o n s u l}$

ēnumerō, 1 , reclate

quamdiū, as lons as campus, i, m., fielel

revocō, I, recall

exhauriō, 4 , hausi, haustus, use up patria, ae, f., natize land impraesentiārum, for the present compōnō, 3. posuī, positus, settle (compose)

colligō, 3. lēgī, lēctus, colle't dīlēctus, ūs, m., l' ' ‘' ${ }^{\prime}$ 


\section{NOTES}

${ }^{1}$ Ligurēs: a tribe in the northwestern part of Italy. 2 afficitur: English derivative? $\quad{ }^{3}$ valētūdine : valeō + tūdō. It means a state of health, either good or bad, according to the context. $\quad$ t Trasumennum: a lake in Etruria. ${ }_{5}^{5}$ occidit: did he do this in spite of premerētur and ferrētur, or because of those acts? ${ }^{6}$ post: adverb. $\quad \bar{A}$ Āuliam: in southern Italy. ${ }^{8}$ obviam vēnērunt: met. ${ }^{9}$ ēnumerāre: English derivative? ${ }^{10}$ Cannēnsem: of Cannc. IIere the Romans met their worst defeat at the hands of Hannibal, in 216 в.c. $\quad{ }^{11}$ invictus : compare English "inconvenient." 12 defeènsum : supine with revocātus. ${ }^{13}$ Padum: the Po. ${ }^{1+}$ Trebiam: a river of northern Italy. Here Hannibal defeated the Romans in 218 в.c. ${ }^{15}$ convēnit: an asserement ai'us made. ${ }^{16}$ Zamam: a town in northern Africa, near which Scipio finally defeated IIannibal in 202 b.C. $1 \tilde{\text { cōnflixit: }}$ synonym of pugnō. 18 insidiātī sunt: deponent formed from the stem of insidiae. $\quad{ }^{19}$ effūgit: ex + fugiō.

\section{EXERCISE XXXV}

Grammar: A. $427,1,2,3: 5+0,2: 563$. B. 229, I : 1 82,1 : 22S, I, $a$; 232, I: 286,$1 ; 295$, I. G. $391 ; 337: 411: 386 ; 5+1 ; 5+6$. H. 49I, II, I, 2,$3 ; 588,11 ; 565$.

Inflection: fīō; mūnus; ācriter : ille.

Order of words: the dependent clauses are arranged in the sentence in the order of their importance in the mind of the writer.

Prescribed list:

$\begin{array}{llll}\text { item } & \text { simul } & \text { susceptum } & \text { creābantur } \\ \text { frāter } & \text { cōnsultō } & \text { hūc } & \text { parī } \\ \text { grātiās } & \text { rogārent } & \text { rediit } & \text { praebuit } \\ \text { pācem } & \text { operā } & \text { bīnì } & \text { penderētur }\end{array}$

corōnā

TIIE CARTIAGINIANS MAKE PEACE WITH THE ROMANS, BUT IIANNIBAL FIGHTS ON UNTIL RECALLED

Cum in apparandōo ${ }^{1}$ ācerrimē esset occupātus, Carthāginiēnsēs bellum cum Rōmānīs composuērunt. Ille nihilō² sētius exercituī posteā praefuit rēsque in Āfricā gèessit itemque Māgō frāter eius ūsque ad Pūblium Sulpicium Gāium Aurēlium ${ }^{3}$ cōnsulēs. Hìs enim magistrātibus lēgātī Carthăginiēnsès Rōmam vēnērunt, quì senātuī 
populōque Rōmānō grātiās agerent ${ }^{4}$ quod cum iīs pācem fēcissent, ob eamque rem corōnā aureā eōs dōnārent, simulque peterent ut obsidēs eōrum Fregellīs ${ }^{j}$ essent captìvique redderentur. Hīs ex senātūs cōnsultō respōnsum est: mūnus eōrum grātum acceptumque esse; obsidēs, quō locō rogārent, futūrōs; captīōs nōn remissūrōs, quod Hannibalem, cuius operā susceptum bellum foret, inimìcissimum ${ }^{6}$ nōminī Rōmānō, etiam nunc cum imperiō apud

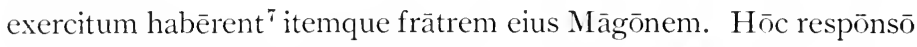
cognitō Carthāginiēnsēs Hannibalem domum et Māgōnem revocārunt. Hūc ut rediit, rēx factus est, postquam imperātor fuerat annō secundō et vīcēsimō; $u t^{8}$ enim Rōmae cōnsulēs, sīc ${ }^{8}$ Carthāgine quotannīs annuī ${ }^{9}$ binn̄i rēgēs creābantur. In eō magistrātū parī dìligentiā sē Hannibal praebuit $\mathrm{ac}^{10}$ fuerat in bellō. Namque effēcit ex novīs vectịgālibus nōn sōlum ut esset pecūnia quae Rōmānīs ex foedere penderētur, sed etiam superesset quae in aerāriō repōnerētur. ${ }^{11}$ - Nepos

\section{VOCABULARY}

compōnō, 3, posuī, positus, settle sētius, the less

üsque, all the time

aureus, a, um, golden

dōnō, 1, present (donor)

grātus, a, um, pleasing

nunc, now revocō, I, recall

vīcēsimus, a, um, twentieth

quotannis, yearly

vectigal, is, n., recienue

pecūnia, ae, f., money (pecuniary)

foedus, eris, n., treaty

aerārium, aerārī, n., treasury

\section{NOTES}

${ }^{1}$ apparandō $:$ ad + parō. $\quad 2$ nihilō $:=$ nihil. For the case, consider sētius. ${ }^{3}$ Sulpicium, Aurelium: the Romans designated a year by the names of the consuls. $\quad{ }^{4}$ agerent: states the purpose of vēnērunt. ${ }^{5}$ Fregellis : Fregella, a city not far from Rome. ${ }^{6}$ inimicissimum: in + amicus. ${ }^{7}$ habērent: the subject refers to the Carthaginians. ${ }^{8}$ ut, sic: introducing ideas which are compared. $\quad{ }^{9}$ annui : adjective from annus. Compare the English "annual." ${ }^{10}$ ac: $a s . \quad{ }^{11}$ repōnerētur: re + pōnō.

What is the force of the prefix in apparando, praefuit, redderentur, remissūrōs, susceptum, revocārunt? 


\section{EXERCISE XXXVI}

Grammar: A. 426, I, 2, 3; 427, I, 2, 3: 530: 53 I, 2. B. 229. I ; I $82, \mathrm{I}, 2 ; 228, \mathrm{I}, a ; 232, \mathrm{I} ; 282, \mathrm{I}, a$. G. 390, $1 ; 337, \mathrm{I} ; 385 ; 386$; 4II; 545, 2. H. 49I, I, I, 2. 3, II, I, 2, 3; 568, I.

Inflection: persuādeō; nāvis: bonus (compare): ìdem.

Order of words: prepositions regularly precede the words which they govern.

\section{Prescribed list :}

$\begin{array}{llll}\text { deinde } & \text { profūgit } & \text { indūcerentur } & \text { ventīs } \\ \text { priusquam } & \text { at } & \text { hūc } & \text { duplex } \\ \text { ascendit } & \text { postquam } & \text { vēla } & \text { namque } \\ \text { clam } & & & \end{array}$

\section{HANNIBAL FLEES FROM CARTHAGE AND TRIES TO BRING ON ANOTHER WAR}

Deinde Mārcō Claudiō Lūciō Füriō cōnsulibus, ${ }^{1}$ Rōmā lēgātī Carthāginem vēnērunt. Hōs Hannibal ratus suī exposcendī² grātiā missōs, ${ }^{3}$ priusquam iīs senātus darētur, nāvem ascendit clam atque in Syriam ad Antiochum profūgit. Hāc rē palam ${ }^{4}$ factā, Poenī nāvīs duās, quae eum comprehenderent, sì possent cōnsequī, mìsērunt ; bona ${ }^{\bar{j}}$ eius pūblicārunt, domum ā fundāmentīs disiēcērunt, ${ }^{6}$ ipsum exsulem iūdicārunt. At Hannibal annō tertiō postquam domō profūgerat, Lūciō Cornēliō Quintō Minuciō cōnsulibus, cum quīnque nāvibus Âfricam accessit in fīnibus C'ȳrēnaeōrum, sī forte Carthāginiēnsēs ad bellum Antiochī spē fìdūciāque ${ }^{7}$ indūcerentur, cui iam persuāserat ut cum exercitibus in İtaliam proficîscerētur. Hūc Māgōnem frātrem excīvit. Id ubi Poenī rescīvērunt, ${ }^{8}$ Māgōnem eādem quā frātrem absentem affēcērunt poenā. Illī dēspērātīs ${ }^{9}$ rēbus cum solvissent nāvēs ac vēla ventīs dedissent, Hannibal ad Antiochum pervēnit. I è Māgōnis interitü ${ }^{10}$ duplex memoria ${ }^{11}$ prōdita est; namque alī̄ naufragiō, alī̄ ā servulìs ipsīus interfectum $^{12}$ eum scrīptum reliquērunt. Antiochus autem paucis nāvibus adversus Rhodiōrum ${ }^{13}$ classem pugnāvit. - NEPos 


\section{VOCABULARY}

reor, 2, ratus, think

comprehendō, 3, hendī, hēnsus, seize

pūblicō, I, confiscate

fundāmentum, i, n., foundation exsul, ulis, m., f., cxile

forte, by chance exciō, +, ivì, itus, call forth

poena, ae, f., punishment

solvō, 3, solvī, solūtus, loose

prōdō, 3, didī, ditus, hand doa'n

naufragium, naufra'gī, n., shipareck servulus, $\overline{1}, \mathrm{~m}$., slate

scrībō, 3, scrīpsī, scrīptus, write

\section{NOTES}

1 cōnsulibus: ablative absolute. ${ }^{2}$ exposcendĩ : ex + poscō; synonym of petō. ${ }^{3}$ missōs : understand esse. ${ }^{4}$ palam: the opposite of clam. ${ }^{5}$ bona: used as a noun. ${ }^{6}$ disiēcērunt: observe the composition. 7 fỉdūciā: synonym of fidēs. ${ }^{8}$ rescivērunt: synonym of cognōscō. 9 dēspērātìs : dē + spērō. English derivative? ${ }^{10}$ interitū: synonym of mors. 11 memoria: account. 12 interfectum: understand esse, and make eum the subject. ${ }^{13}$ Rhodiōrum: the people of Khodes.

Determine from their position whether these words are emphatic: hōs, clam, Carthāginiēnsēs, poenā, pervēnit.

\section{EXERCISE XXXVII}

Grammar: A. 409, $a: 5+9: 564: 57+$. B. $218.8: 286,2: 296,2$; 300,1 . G. 405; 586; 550, 2: 467. H. 477. II; 598: 567, 1; 649, II.

Inflection: capiō ; cōnsilium; simulāns : quisquam.

Order of words: adjectives of quantity normally precede their nouns. Prescribed list:

$\begin{array}{llll}\text { dēderētur } & \text { nisi } & \text { sciēbat } & \text { tolleret } \\ \text { potestātem } & \text { prōīidisset } & \text { exīsse } & \text { quisquam } \\ \text { cōnferret } & \text { enim } & \text { complet } & \text { conciliābat } \\ \text { callidissimus } & \text { portābat } & \text { dēpōnit } & \end{array}$

HIANNIBAL CONCEALS IIIS TREASURE

Antiochō fugātō, verēns nē dēderētur, quod ${ }^{1}$ sine dubiō accidisset, sī suī fēcisset potestātem, ${ }^{2}$ Crētam ad Gortȳniōs ${ }^{3}$ vēnit, ut ibi, quō sē cōnferret, cōnsīderāret. Vìdit autem vir ${ }^{4}$ omnium callidissimus in magnō sē fore perīculō, nisi quid prōvīdisset, propter avāritiam 
Crētēnsium $^{5}$ : magnam enim sēcum pecūniam portābat, dē quā sciēbat exīsse fāmam. Itaque capit ${ }^{6}$ tāle cōnsilium. ${ }^{7}$ Amphorās complūrīs complet plumbō, summās operit aurō et argentō. Hās praesentibus prīncipibus dēpōnit in templō Diānae, simulāns sē suās fortūnās illōrum ${ }^{8}$ fideī crēdere. Hìs in errōrem inductīs, ${ }^{9}$ statuās aēneās, quās sēcum portābat, omnī suā pecūniā complet eāsque in prōpatulō domì abicit. ${ }^{10}$ Gortȳnīi templum magnā cūrā ${ }^{11}$ custōdiunt, nōn tam ā cēterīs ${ }^{12}$ quam ab Hannibale, nē ille innscientibus ${ }^{13}$ īis tolleret sua sēcumque dūceret. Sìc cōnservātīs suìs rēbus Poenus, illūsīs Crētēnsibus omnibus, ad I'rūsiam ${ }^{14}$ in Pontum pervēnit. Apud quem eōdem animō fuit ergā İtaliam, neque aliud quicquam ēgit quam rēgem armāvit et exercuit adversus Rōmānōs. Quem ${ }^{15}$ cum vidēret domesticiss opibus minus esse rōbustum, conciliābat cēterōs rēgēs, adiungēbat bellicōsās nãtiōnès. — NEpos

\section{VOCABULARY}

fugō, I, put to flight
dubius, a, um, doubtful
avāritia, ae, f., grecd (avaricious)
pecūnia, ae, f., monèy
fāma, ae, f., report (famous)
tālis, e, such
amphora, ae, f., jar
plumbum, i, n., lèd
operiō, t, uī, tus, con'er
aurum, i, n., gold
argentum, i, n., sili'er

fugō, I, put to flight

dubius, a, um, doubtful

pecūnia, ae, f., money

fāma, ae, f., report (famous)

tălis, e, strch

plumbum, i, n., lead

operiō, 4 , uì, tus, cocer

argentum, $\bar{i}, \mathrm{n}$., silie't

\author{
simulō, I, fretend \\ crēdō, 3 , didī, ditus, trust (credence) \\ aēneus, a, um, bronze \\ prōpatulum, i, n., open court \\ custōdiō, + , ìvì, ìtus, guard (custody) \\ cōnservō, I, saz'e \\ illūdō, 3 , lūsí, lūsus, make sport of \\ ergā, tociords \\ exerceō, 2, uī, itus, arouse \\ (ops), opis, f., méuns \\ bellicōsus, a, um, warlike
}

\section{NOTES}

1 quod: refers to nē dēderētur. ${ }^{2}$ suī potestātem: a chance at him. ${ }^{3}$ Gortȳniōs: people of the city of Gortyna in Crete. ${ }^{4}$ vir: not the subject of vīdit. What then is its syntax? ${ }^{5}$ Crētēnsium: compare Carthāginiēnsium. $\quad{ }^{6}$ capit: adopts. ${ }^{7}$ cōnsilium: what follows explains this. 8 illörum: refers to principibus. 9 inductis : observe the composition. 10 abicit: observe the composition; $a b=$ de. $\quad{ }^{11}$ cūrā : related to the verb 
cūrō. 12 cēterīs : synonym of reliquĩ. $\quad{ }^{13}$ inscientibus : observe the composition. Compare the English "secure" and "insecure." ${ }^{1+}$ Prūsiam: Prusias, the king. $\quad 15$ quem: not the object of videret.

Determine the force of the prefix in prōvidisset, dēpōnit, inductis, $a b$ icit, adiungēbat.

\section{EXERCISE XXXVIII}

Grammar: A. $349 ; 563 ; 564 ; 569,2$. B. $204,1: 295,1$ : 296, 2 ; 297,2 . G. $374 ; 5+6,2 ; 550,1,2 ; 553,3$. H. $450 ;+51,1 ; 565$; $567,1: 571,1$.

Inflection: fīó; domus ; facile (compare); sūi.

Order of words: the modifying phrase usually precedes the word which it modifies.

Prescribed list :

$\begin{array}{llll}\text { dum } & \text { ausus est } & \text { castellō } & \text { sēnsit } \\ \text { cāsū } & \text { recūsāvit } & \text { mūnerī } & \text { aliēnō } \\ \text { rēgnō } & \text { iūs } & \text { aedificārat } & \text { prīstinus } \\ \text { dētulit } & \text { hospitī } & \text { circumdedissent } & \text { sūmpsit } \\ \text { insidī̄s } & & & \end{array}$

HOW THE ROMANS BROLGHT ABOLT HANNIBAL'S IDEATH

Quae dum in Asiā geruntur, accidit cāsū ut lēgātī Prūsiae ${ }^{1}$ Rōmae apud ${ }^{2}$ Titum Quinctium Flāmininum cōnsulārem cēnārent, atque, ibi dē Hannibale mentiōne factā, ex iis ūnus diceret eum in Prūsiae rēgnō esse. Id posterō diē Flāmininnus senātuī dētulit. Patrēs cōnscrīptī, ${ }^{3}$ quī Hannibale vīvō numquam sē sine ìnsidī̄s futūrōs exīstimārent, ${ }^{4}$ lēgātōs in Bìthȳniam misērunt, in ī̄s Flāmininum, quī ab rēge peterent nē inimīcissimum ${ }^{5}$ suum sēcum habēret sibique dēderet. Hìs Prūsiās negāre ausus nōn est: illud recūsāvit, nē id à sē fierī postulārent quod adversus iūs hospitī esset; ipsī, sī possent, comprehenderent ${ }^{6}$; locum ubi esset facile inventūrōs. ${ }^{7}$ Hannibal enim ūnō locō sē tenēbat in castellō, quod eì à rēge datum erat mūnerī, ${ }^{8}$ idque sīc aedificārat ut in omnibus partibus aedificì exitūs habēret, scīlicet verēns nē ùsū venīret ${ }^{9}$ quod accidit. Hūc cum lēgātī Rōmānōrum vēnissent ac multitūdine 
domum eius circumdedissent, puer ab iānuā prōspiciēns Hannibalī dīxit plūrīs praeter cōnsuētūdinem armātōs appārēre. Quĩ imperāvit eî ut omnīs forīs ${ }^{10}$ aedificì circumìret ac propere ${ }^{11}$ sibi nūntiāret num eōdem modō undique obsidērētur. Puer cum celeriter quid esset renūntiāsset omnisque exitūs occupātōs ostendisset, sēnsit id nōn fortuîtō ${ }^{12}$ factum, ${ }^{13}$ sed sē petī neque sibi diūtius vîtam esse retinendam. Quam nē aliēnō arbitriō dimitteret, memor prīstinārum virtūtum, venēnum, quod semper sēcum habēre cōnsuērat, sūmpsit. - NePos

\section{VOCABULARY}

cōnsulāris, is, m., c.x-cousul

cēnō, I, dine

vivus, a, um, alic'e

numquam, ner'er

negō, I, say "no" (negative)

comprehendō, 3 , hendī, hēnsus, scize'

scilicet, evidently'

iānua, ae, f., door

prōspiciō, 3, spexī, spectus, watìh appāreō, 2.uī, _ , appiear num, whether

obsidēō, 2, sēdī, sessus, beset vita, ae, f., life

arbitrium, arbi'trī, n., will memor, memoris, mindful venēnum, i, n., poison semper, alicays

\section{NOTES}

1 Prūsiae: genitive; Prusias, king of the state in which IIannibal was then living. '2 apud: at the hon se of. ${ }^{3}$ patrēs cōnscriptì: a term applied to the senators; cōnscrīptī, enrolled. ${ }^{4}$ qui . . . exīstimārent: gives a reason for misērunt. 5 inimicissimum: in + amīcus, greatest enc'my. ${ }^{6}$ ipsī . . . comprehenderent: indirect discourse, depending on recūsāvit; comprehenderent represents an imperative in the words of Prusias. 7 inventūrōs: in + veniō; in, upon. ${ }^{8}$ mūnerī: dative showing purpose. 9 ūsū veniret: = accideret. ${ }^{10}$ foris: synonym of iānua. ${ }^{11}$ properē : synonym of celeriter. 12 fortuītō: synonym of cāsū. ${ }^{13}$ factum: understand esse.

Think of English words from accidit, mīsērunt, peterent, negāre, inventūrōs, prōspiciēns. 


\section{EXERCISE XXXIX}

Grammar: A. 367: 372; 415:546. B. I $87, \mathrm{II}, a, b: 224: 288,1, \mathrm{~B}$. G. 346 , R. I : $400 ; 585$. H. 426. 1, 3: 473, 2; 600, II, I.

Inflection: gerō; adventus; superior: ipse.

Order of words: in the ablative absolute the emphatic word, usually the noun, stands first.

Prescribed list:

$\begin{array}{llll}\text { marī } & \text { occāsiōne } & \text { insulās } & \text { refectae } \\ \text { terrā } & \text { lacessīvit } & \text { statuērunt } & \text { renovāre } \\ \text { cessit } & \text { paene } & \text { etsī } & \text { nisi } \\ \text { nocendī } & \text { ămīsissent } & \text { statim } & \text { trādere } \\ \text { saepe } & \text { classe } & & \end{array}$

IIAMILCAR, TIIE CAKTIAGINIAN, AGREES TO PEACE WITH THE ROMANS, BLT HOPES FOR A CHANCE TO FIGHT AGAIN

Hamilcar, Hannibalis ${ }^{1}$ fïlius, cognōmine Barca, Carthāginiēnsis, prīmō Pūnicō bellō, sed temporibus ${ }^{2}$ extrēmīs, admodum adulēscentulus in Siciliā praeesse coepit exercituī. Cum ${ }^{3}$ ante eius adrentum et marī et terrā male rēs gererentur Carthāginiēnsium, ipse ubi adfuit numquam hostī cessit neque $\operatorname{locum}^{4}$ nocendī dedit, saepeque è contrāriō occāsiōne datā lacessivit "s semperque superior discessit. ( (uō factō, cum paene omnia in Siciliā Poenī āmisissent, ille Erycem "sìc dēfendit ut bellum eō locō gestum nōn vidērētur. Interim Carthāginiēnsēs classe ${ }^{\bar{T}}$ apud īnsulās Aegătēs ā Gāiō Lutātiō, cōnsule Rōmānōrum, superātī statuērunt bellì facere fīnem, eamque rem arbitriō permìsērunt Hamilcaris. Ille etsī flagrābat bellandī cupiditāte, ${ }^{8}$ tamen pācī serviendum ${ }^{9}$ putāvit, quod patriam exhaustam sūmptibus ${ }^{10}$ diūtius calamitātēs belli ferre nōn posse intellegēbat; sed ita ut statim mente agitāret. ${ }^{11}$ sì paulum modo rēs essent refectae, bellum renovāre Rōmānōsque armīs persequi ${ }^{12}$ dōnicum aut virtūte vīcissent aut victī manūs dedissent. Hōc cōnsiliō pācem conciliārit. In quō ${ }^{13}$ tantā fuit ferōciā, ${ }^{1+}$ cum Catulus 
negāret bellum compositūrum ${ }^{15}$ nisi ille ${ }^{16}$ cum suīs, quī Erỳcem tenērent, armīs relictīs Siciliā dēcēderent, ut succumbente patriā ipse peritūrum sē potius dīxerit ${ }^{17}$ quam cum tantō flāgitiō domum rediret; nōn enim suae esse virtūtis ${ }^{18}$ arma à patriā accepta adversus hostìs adversāriìs trādere. Huius ${ }^{19}$ pertinàciae cessit Catulus. - Nepos

\section{VOCABULARY}
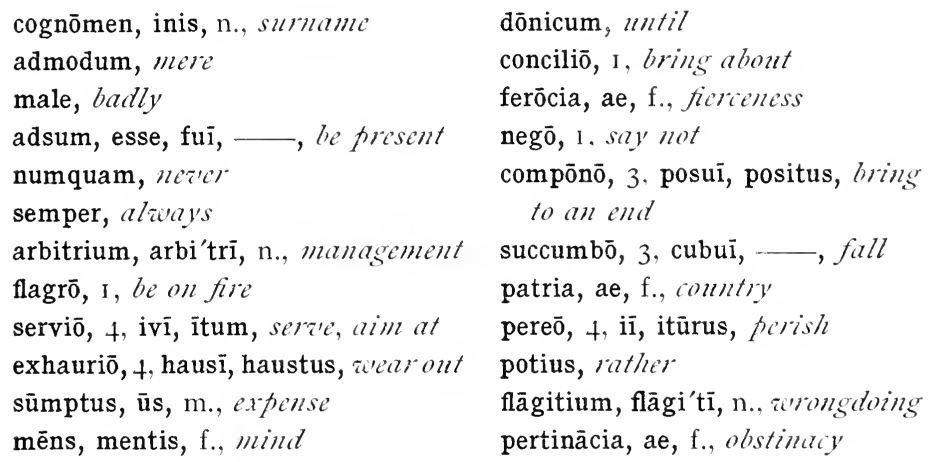

\section{NOTES}

${ }^{1}$ Hannibalis: not the IIannibal mentioned elsewhere, who was Hamilcar's son. ${ }^{2}$ temporibus: i.e. huius belli. ${ }^{3}$ cum: concessive. ${ }^{4}$ locum: = occāsiō. $\quad{ }^{5}$ lacessivit: understand hostis. ${ }^{6}$ Erycem: Eryx, a town in Sicily. ${ }^{7}$ classe: states the means of superātī. ${ }^{8}$ cupiditāte: cupidus + tās. ${ }^{9}$ serviendum: understand sibi. ${ }^{10}$ sūmptibus: states the cause of exhaustam. 11 mente agitāret: nearly equal to putāret, but has also the idea of intend. ${ }^{12}$ persequī : composition? ${ }^{13}$ quō: refers to pãcem conciliāvit. ${ }^{14}$ ferōciā: describes the subject of fuit. ${ }^{15}$ compositūrum: understand sē. $\quad 16$ ille: i.e. Hamilcar. $\quad 17$ ut ... dixxerit: keep in mind tantā above. ${ }^{18}$ virtūtis: shows possession, the thing possessed being arma ....trādere. $\quad{ }^{19}$ huius: i.e. Hamilcar. 


\section{EXERCISE XL}

Grammar: A. 305 ; 404: 540, I: 549. B. 250: 219; 286, I, 2. G. 6It: 408: 5 to: 586 . H. 396; $475 ; 588, \mathrm{I} ; 598$.

Inflection: oppugnō; imperātor : plūs : hīc.

Order of words: a noun depending on another noun usually stands next to it, either before or after it, according to the emphasis.

Prescribed list:

$\begin{array}{llll}\text { aliter } & \text { perterritī } & \text { amplius } & \text { reddidit } \\ \text { namque } & \text { impetrārunt } & \text { compulit } & \text { reperīret } \\ \text { parī } & \text { prope } & \text { valentissima } & \text { praetereā } \\ \text { nisi } & \text { mūrìs } & \text { restituit } & \text { mōrēs } \\ \text { rìgintī } & & & \end{array}$

HAMILCAR FINDS CARTHAGE BESET BY ENEMIES, BLT DEFEATS THEM ANH TIIEN SETS OLT FOR SPAIN

At ille ut Carthāginem vēnit, multō aliter $\mathrm{ac}^{1}$ spērārat $^{2}$ rem pūblicam sē habentem ${ }^{3}$ cognōvit. Namque diūturnitāte ${ }^{4}$ externī malì tantum exārsit intestīnum bellum ut numquam in parì perīculō fuerit Carthāgōo, nisi cum dēlēta est. Prīmō mercēnnārī mìlitēs quibus adversus Rōmānōs ūsī erant dēscivērunt, quōrum numerus erat vīgintī mìlium. İ̀ tōtam abaliēnārunt Āfricam, ipsam Carthāginem oppugnārunt. Quibus malīs adeō sunt Poeni perterritī ut etiam auxilia ab Rōmānīs petierint; eaque ${ }^{6}$ impetrārunt. Sed extrēmō, cum prope iam ad dēspērātiōnem ${ }^{\top}$ pervēnissent, Hamilcarem imperātōrem fēcērunt. Is nōn sōlum hostīs ā mūrīs Carthāginis remōvit, cum amplius centum mīlia facta essent armātōrum, sed etiam eo ${ }^{8}$ compulit ut locôrum angustī̄s clausì plūrēs fame quam ferrō $^{9}$ interīent. $^{10}$ Omnia oppida abaliēnāta, in iìs Uticam atque Hippōnem, valentissima tōtīus Āfricae, restituit patriae. Neque eō fuit contentus, sed etiam fīnīs imperī prōpāgāvit, ${ }^{11}$ tōtā Áfricā ${ }^{12}$ tantum òtium ${ }^{13}$ reddidit ut nüllum in eā bellum vidērētur multîs annîs fuisse. Rēbus hìs ex sententiā perāctīs fìdentī animōo atque înfēstō Rōmānìs, quōo ${ }^{14}$ facilius causam bellandī 
reperīret, effēcit ut imperātor cum exercitū in Hispāniam mitterētur, eōque sēcum dūxit fīlium Hannibalem annōrum novem. Erat praetereā cum eō adulēscēns illūstris, fōrmōsus, Hasdrubal. Huic ille fîliam suam in mātrimōnium dedit. I ēe hōc ideō mentiōnem fēcimus, quod Hamilcare occīsō ille exercituī praefuit rēsque magnās gessit, et prīnceps largîtiōne vetustōs ${ }^{1 \bar{j}}$ pervertit mōrēs Carthāginiēnsium, eiusdemque post mortem Hannibal ab exercitū accēpit imperium. - NEPos

\section{VOCABULARY}

diūturnitās, ātis, f., length

malum, i, n., misfortune

exārdēscō, 3, ārsī, — blaze

forth

intestīnus, a, um, ciril

numquam, neier

dēleō, 2, èvī, ètus, destroy

mercēnnārius, a, um, hired

dēscīscō, 3, scīvī, —, desert

abaliēnō, I, make hostile

claudō, 3 , clausī, clausus, he'm in famēs, is, f., hunger

patria, ae, f., country

fïdēns, fīdentis, confident

infëstus, a, um, hostile

adulēscēns, centis, m., youth

illūstris, e, distinguished

fōrmōsus, a, um, landsome

mātrimōnium, mātrimōnī, n., marriage ideō, for this reason

largitiō, ōnis, f., lazish giving

pervertō, 3 , vertī, versus, cormut

\section{NOTES}

${ }^{1}$ ac: than. ${ }^{2}$ spērārat: note the shortened form. There are others in the passage. ${ }^{3}$ sē habentem: in a condition. ${ }^{4}$ diūturnitāte: states the cause of exārsit. $\quad{ }^{5}$ adeō: synonym of ita. $\quad{ }^{6}$ ea: refers to auxilia. 7 dēspērātiōnem: dē + spērō + tiō. $\quad{ }^{8}$ e⿳亠丷厂 : to such a point. ${ }^{9}$ ferrō: used for gladius. ${ }^{10}$ interirent: nearly equivalent here to interficerentur. ${ }^{11}$ prōpāgāvit: synonym of augeō. ${ }^{12} \bar{A}$ fricā: in is omitted with tōtā. 13 ōtium : nearly equivalent to pāx. ${ }^{14}$ quō: introduces a purpose clause when the clause contains a comparative. $\quad 15$ vetustōs: synonym of vetus. 


\section{EXERCISE XLI}

Grammar: A. 376: $578: 579 ; 5$ So. B. I8s, I: 313: 314 1 ; 33I, 1. G. 350. 2: 648: 650. H. 425.4: 64I: 642:643.

Inflection: $\bar{o} g \bar{o}$; classis; vetus: suus.

Order of words: the normal order of the sentence is (I) subject, (2) modifiers of subject, (3) modifiers of verb, (4) verb.

Prescribed list:

$\begin{array}{llll}\text { ulteriōrem } & \text { complēverat } & \text { mandātīs } & \text { castellīs } \\ \text { quō } & \text { adulēscentīs } & \text { portās } & \text { înstituerant } \\ \text { septem } & \text { officia } & \text { fidē } & \text { reficiēbant }\end{array}$

\section{CASAR FINDS TIHT THE CITY OF MASSILIA IS MAKING REAHY TO OPPOSE IHII}

Cæsar and Pompey once had been friends. Indeed, Pompey had married Cæsar's daughter Julia, and had been closely associated with him in some of his greatest undertakings. But the changing circumstances of the times and Julia's death had weakened the ties that once bound them, and they were now enemies. Cæsar has just been in Rome, and through the senate has tried to bring about a reconciliation with Pompey, but in vain.

Caesar ab urbe proficiscitur atque in ulteriōrem Galliam pervenit. Quō cum vēnisset, cognōscit missum ${ }^{1}$ in Hispāniam² à Pompēiō Vỉbullium Rūfum, quem paucīs ante diēbus Corfīniō ${ }^{3}$ captum $^{4}$ ipse dimiserat; profectum item Iomitium ${ }^{5}$ ad occupandam Massiliam ${ }^{6}$ nāvibus āctuāriīs septem, quās Igilī $^{\top}$ et in Cosānōo à prīvātīs coāctās servīs, lỉbertīs, colōnīs suīs complēverat; praemissōs etiam lēgātōs Massiliēnsīs ${ }^{9}$ domum, nōbilīs adulēscentīs, quōs ab urbe discēdēns Pompēius erat adhortātus ${ }^{10}$ nē nova Caesaris officia veterum suōrum ${ }^{11}$ beneficiōrum in ē̄s memoriam expellerent. Quibus mandātīs acceptīs Massiliēnsēs portās Caesarī ${ }^{12}$ clauserant; Albicōs, barbarōs hominēs, quī in eōrum fidē antīquitus erant montīsque suprā Massiliam incolēbant, ad sē vocāverant; frūmentum ex fīnitimīs regiōnibus atque ex omnibus castelliss in urbem convexerant; armōrum officinās in urbe īnstituerant; mūrōs, portās, classem reficiēbant. - De Bello Civili, I, 33, 34 


\section{VOCABULARY}

āctuārius, a, um, swijt

servus, $\overline{1}, \mathrm{~m}$. , slave

libertus, i, m., fieedman

colōnus, $\overline{1}, \mathrm{~m}$. ., colonist

claudō, 3, clausì, clausus, shut antīquitus, in olden times

vocō, I, summon

convehō, 3 , vexī, vectus, collect officina, ae, f., manufactory

\section{NOTES}

1 missum: understand esse. Why? 2 Hispāniam: Sfain. ${ }^{3}$ Corfīniō: a town in central Italy. * captum: translate by a temporal clause. ${ }^{5}$ Domitium: an adherent of Pompey, afterwards in command of the defense of Massilia. ${ }^{6}$ Massiliam: Marseilles. $\quad 7$ Igili: a small island off the coast of Italy, not far from Rome. ${ }^{8}$ Cosānō: the territory belonging to Cosa, a town near the coast, northwest of Rome. ${ }^{9}$ Massiliēnsis : Massilia + ēnsis, -ian. $\quad{ }^{10}$ adhortātus : = hortātus. ${ }^{11}$ suōrum: refers to Pompey. 12 Caesarī: dative of reference.

Observe the force of the prefix in dimmiserat, praemissōs, expellerent, reficiēbant.

\section{EXERCISE XLII}

Grammar: A. 3+3,c: +52, I ; +8, a, b. B. 19S, 3:330:267, 2, 3 . G. 366,$2 ; 422 ; 509: 510$. H. 439,$5 ; 615 ; 5+3 ; 5+4 ; 545$.

Inflection: augeō; vīs: pār; is.

Order of words: in a phrase the emphatic word usually stands first.

Prescribed list:

$\begin{array}{llll}\text { agit } & \text { dēbēre } & \text { pār } & \text { iuvāre } \\ \text { initium } & \text { voluntātī } & \text { quoque } & \text { portibus } \\ \text { oriātur } & \text { utra } & \text { neutrum } & \end{array}$

C.ESAR TRIES TO GAIN THE SLPPORT OF TIE, MASSILIANS, BLT TIIEY IECIIE TO REMAIN NEUTRAL

Ẽvocat ad sē Caesar Massiliā quindecim prīmōs. ${ }^{1}$ Cum hīs agit nē initium innferendỉ bellì ab Massiliēnsibus oriātur²: dēbēre eōs İ taliae tōtīus auctōritätem sequī potius quam ūnīus hominis voluntātī obtemperāre. Reliqua quae ad eōrum sānandās mentisš̉ pertinēre 
arbitrābātur ${ }^{4}$ commemorat. Cuius ōrātiōnem lēgātī domum referunt atque ex auctöritāte haec Caesarī renūntiant: intellegere sē dīvīsum esse $^{j}$ populum Rōmānum in duās partīs. Neque suī iū $\operatorname{dic}^{6}{ }^{6}$ neque suārum esse vīrium discernere utra pars iūstiōrem habeat causam. Prīncipēs rērō esse eārum partium Gnaeum Pompēium et Gāium Caesarem, patrōnōs civitātis; quōrum alter ${ }^{7}$ agrōs Volcārum ${ }^{8}$ Arecomicōrum et Helviōrum pūblicē iīs concesserit, alter bellō victōs Sallyas ${ }^{9}$ attribuerit vectīgāliaque auxerit. Quārē paribus eōrum beneficīis ${ }^{10}$ parem sē quoque voluntātem tribuere dēbēre et neutrum eōrum contrā alterum iuvāre aut urbe aut portibus recipere. - De Bello Civili, I, 35

\section{VOCABULARY}

ēvocō, I, summon

potius, rather

obtemperō, I, heed

sānō, 1 , heal

commemorō, I, mention iūđicium, iūdi'cī, n., judgment

discernō, 3 , crēvī, crētus, decide

attribuō, 3, uī, ūtus, assign

vectīgal, ālis, n., revenue

\section{NOTES}

${ }^{1}$ prīmōs: understand cīvīs. ${ }^{2}$ oriātur: states the purpose of agit. ${ }^{3}$ eôrum sānandās mentīs: bringing the'm to their senses; mentīs is a synonym of animus. $\quad{ }^{4}$ arbitrābātur: synonym of putō. ${ }^{5}$ divīisum esse : depends on intellegere. $\quad{ }^{6}$ iūdicī : shows possession. $\quad{ }^{7}$ alter: Pompey. ${ }^{8}$ Volcārum, etc.: tribes of Gaul. ${ }^{9}$ Sallyas: a tribe dwelling not far from Massilia. Accusative plural. $\quad{ }^{10}$ paribus eōrum beneficiiss: gives a reason for parem sē voluntātem tribuere dēbēre.

Observe the emphasis in the following phrases: inferendi bellī, İtaliae tōtīus, ūnīus hominis, iūstiōrem causam.

\section{EXERCISE XLIII}

Grammar: A. 3 $46, a, 3$ : +20, I: 423. I ; 503. B. 201, 2: 227, 2, $a$; 231: 339. I. 2. (i. 369: +10:393: 427. H. +4I: +89.1: 487;623; $626: 628$.

Inflection: ūtor ; portus ; reliquus; quī. 
Order of words: a prepositional phrase usually limits a word following it. Prescribed list:

$\begin{array}{llll}\text { summa } & \text { ubīque } & \text { māteriā } & \text { obsidiōnem } \\ \text { administrandī } & \text { portum } & \text { armandās } & \text { turrīs } \\ \text { permittitur } & \text { dēdūcunt } & \text { reficiendās } & \text { vīneās } \\ \text { onerāriās } & \text { parum } & \text { commeātūs } & \text { caesa est }\end{array}$

DOMITIUS REACHES MASSILIA ANI) MAKES PREPARATIONS FOR ITS DEFENSE

Haec dum inter eōs aguntur, Domitius ${ }^{1}$ nāvibus Massiliam pervenit atque ab īis ${ }^{2}$ receptus urbì praeficitur; summa eì bellī administrandī permittitur. Eius imperiō classem quōqueversus dīmittunt; onerāriās nāvīs, quās ubīque possunt, ${ }^{3}$ dēprehendunt atque in portum dēdūcunt, parum chāinis ${ }^{4}$ aut māteriā atque armāmentīs înstrūctīs ad reliquās armandās ${ }^{5}$ reficiendāsque ūtuntur; frūmentī quod ${ }^{6}$ inventum est, in pūblicum cōnferunt; reliquās mercēs commeātūsque ad obsidiōnem urbis, sī accidat, reservant. Quibus iniūriìs ${ }^{\top}$ permōtus Caesar legiōnēs trīs Massiliam addūcit; turrīs vīneāsque ad oppugnātiōnem urbis agere, nāvīs longās Arelāte ${ }^{8}$ numerō duodecim facere instituit. Quibus effectīs armātīsque diēbus trīgintā, ā quā diè māteria caesa est, adductīsque Massiliam, hìs Decimum Brūtum praeficit, Gāium Trebơnium lēgātum ad oppugnātiōnem Massiliae relinquit. - 1)E Bello Civilı, I, 36

\section{VOCABULARY}

quōqueversus, in ea'ery direction dēprehendō, 3 , hendī, hēnsus, catch suddenly

clāvus, ī, m., nail armāmentum, i, n., equipment inveniō, + , vēnì, ventus, comle upon, find merx, mercis, f., merhandise

\section{NOTES}

${ }^{1}$ Domitius : an adherent of Pompey. 2 iis: refers to the Massilians. ${ }^{3}$ possunt: understand an infinitive from dēprehendunt. ${ }^{4}$ clāvīs : answers the question "with what" about instrūctīs, which depends on ūtuntur. 
5 armandās, etc. : states the purpose of ütuntur. $\quad{ }^{6}$ quod: a relative limited by frūmentī. ${ }^{7}$ iniūrī̄s: refers to what precedes. ${ }^{8}$ Arelāte: Arelas, a town not far from Massilia. What fact does it state about facere?

Complete from the above passage the expressions of which each of the following phrases forms a part: ab iīs, in portum, in pūblicum, ad obsidiōnem, ā quā diē, ad oppugnātiōnem.

\section{EXERCISE XLIV}

Grammar: A. 346, a, 3; to6: 409; +1 S. B. 201, 2 ; 217, I ; 218 ; 226. G. 369; 39S: 40I; 397. H. 44I; 47I; 476; 4 So.

Inflection: terrē̄; mūnus; minor; ipse.

Order of words: the antecedent of a relative is usually in the preceding clause, and is often the word immediately before the relative.

Prescribed list :

$\begin{array}{llll}\text { hūc } & \text { impōnunt } & \text { insulam } & \text { centuriōnēs } \\ \text { classis } & \text { praemī̄s } & \text { statiōnēs } & \text { mūneris } \\ \text { suprā } & \text { prōcēdunt } & \text { inferior } & \text { ferreās }\end{array}$

DOMITIUS AND BRUTUS, CASAR'S LIEUTENANT, PREPARE FOR A NAVAL BATTLE

Massiliēnsēs ūsīi Lūcī Domitī cōnsiliō nāvīs longās expediunt numerō septendecim, quārum erant ūndecim tēctae. ${ }^{2}$ Multa hūc minōra nāvigia addunt, ut ipsā multitūdine nostra classis terreātur. Magnum numerum sagittāriōrum, magnum Albicōrum, ${ }^{3}$ dē quibus suprā dēmōnstrātum est, impōnunt atque hōs praemī̄s pollicitātiōnibusque incitant. Certās sibi dēposcit ${ }^{4}$ nāvīs Domitius atque hās colōnīs ${ }^{5}$ pāstōribusque, quōs sēcum addūxerat, complet. Sīc omnibus rēbus ${ }^{6}$ instrūctā classe, magnā fỉdūciā ${ }^{7}$ ad nostrās nāvīs prōcēdunt, quibus praeerat Decimus Brūtus. Hae ad insulam, quae est contrā Massiliam, statiōnēs obtinēbant. Erat multōinferior numerō nāvium Brūtus; sed ēlēctōs ex omnibus legiōnibus fortissimōss virōs, antesignānōs, centuriōnēs, Caesar eī classī attribuerat, ${ }^{8}$ qui sibi id mūneris ${ }^{9}$ dēpoposcerant. Hì manūs ferreās atque harpagōnēs parāverant.

De Bello Civili, I, 56, 57 


\section{VOCABULARY}

tegōo, 3, tēxī, tēctus, corer nãvigium, nāvi'gī, n., boat terreō, 2. ūi, itus, frighten pollicitātiō, ōnis, f., promise colōnus, ì, m., colonist pāstor, ōris, m., shcpherd èligō, 3, lēgī, lēctus, select antesignānus, $\overline{1}, \mathrm{~m}$., r'eteran harpagō, ōnis, m., grappling hook

\section{NOTES}

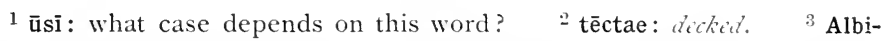
cōrum: a tribe dwelling not far from Massilia. ${ }^{4}$ dēposcit: synonym of poscit. 5 colonis: answers the question "with what" about complet. ${ }^{6}$ rēbus: limits instrūctā. ${ }^{7}$ fĩdūciāa : synonym of fidès. It answers the question "how" about prōcēdunt. $\quad{ }^{8}$ attribuerat: nearly synonymous with praeficiō. $\quad{ }^{9}$ mūneris: limits id.

Think of English words from numerō, minōra, pāstōribus, complet, ēlēctōs, and observe how the English word retains the meaning of the Latin.

\section{EXERCISE XLV}

Grammar: A. $208, d: 4$ I $8: 504$. B. 256,$3 ; 226 ; 338,1, a$. G. 208,$2 ; 397 ; 428$. H. 302, 6; 4 So; 626 .

Inflection: impediō; diēs; uterque: noster.

Order of words: a dependent genitive, unless emphatic, usually follows the word which it limits.

Prescribed list :

$\begin{array}{llll}\text { portū } & \text { celeritāte } & \text { prōductā } & \text { aequōo } \\ \text { utrimque } & \text { gubernātōrum } & \text { propius } & \text { bīnis } \\ \text { cēdēbant } & \text { excipiēbant } & \text { perīīis } & \text { obiciēbant } \\ \text { modo } & \text { quoad } & \text { onerāriīs } & \text { compellunt } \\ \text { operam } & \text { licēbat } & & \end{array}$

THE NAVAL BATTLE BETWEEN THE MASSILIANS AND THE ROMANS

Ita cognitō hostium adventū suās nāvīs ex portū Rōmānī èdūcunt, cum Massiliēnsibus cōnflīgunt. ${ }^{1}$ Pugnātum est utrimque fortissimē atque ācerrimē; neque multum Albicīen nostrīs virtūte ${ }^{3}$ 
cēdēbant, hominēs asperī et montānī ${ }^{4}$ et exercitātī in $\operatorname{armiss}^{5}$; atque hì modo dịgressĩ ā Massiliēnsibus recentem eōrum pollicitātiōnem animìs continēbant, ${ }^{6}$ pāstōrēsque I omitī spē lỉbertātis excitātī sub oculīs dominī suam probāre operam studēbant. Ipsī Massiliēnsēs et celeritāte nāvium et scientiā̄ gubernātōrum cōnfīsì nostrōs èlūdēbant impetūsque eōrum nōn excipiēbant et, quoad licēbat lātiōre ùtī spatiō, prōductā longius aciè circumvenire nostrōs aut plūribus nāvibus adorīrī singulās, ${ }^{8}$ sì possent, contendēbant; cum propius ${ }^{9}$ erat necessāriō ventum, ab scientiā gubernātōrum atque artificī̄s ad virtūtem montānōrum cōnfugiēbant. Nostrī cum ${ }^{10}$ minus exercitātīs rèmigibus minusque perītis gubernātōribus ūtēbantur, quī repente ex onerāriìs nāvibus erant prōductī, tum etiam tarditāte $^{11}$ et gravitāte ${ }^{122}$ nāvium impediēbantur. Itaque, dum locus comminus pugnandī darētur, aequō animō singulās bīnìs nāvibus obiciēbant, atque in hostium nāvīs trānscendēbant, ${ }^{13}$ et, magnō numerō Albicōrum et pāstōrum interfectō, partem nāvium dēprimunt, nōnnūllās cum hominibus capiunt, reliquās in portum compellunt. Eō diè nầvès Massiliēnsium, cum iîs quae sunt captae, intereunt novem. ${ }^{1+}$ - I) E Bello Civili, I, $57,5^{8}$

\section{VOCABULARY}

asper, era, erum, rough

exercitō, I, train

digredior, 3, gressus, depart pollicitātiō, ōnis, f., promise pāstor, ōris, m., shcpherrd oculus, $\overline{\mathrm{i}}, \mathrm{m} .$, eye

dominus, $\overline{\mathrm{i}}, \mathrm{m} .$, master èlūđō, 3, lūsī, lūsus, escape artificium, artifi'cī, n., derice, trick cōnfugiō, 3 , fūgì, _. rēmex, igis, m., rower repente, suddenly comminus, at close quarters dēprimō, 3, pressī, pressus, $\operatorname{sink}$ intereō, 4 , ì, itum, perish

\section{NOTES}

${ }^{1}$ cōnfliggunt: synonym of pugnō. $\quad{ }^{2}$ Albicì : a tribe dwelling near Massilia. " 3 virtūte: answers the question "in what respect" about ceedēbant. ${ }^{4}$ montānī: mōns + ânus, belonging to. ${ }^{5}$ hominēs . . . armìs: this tells why the statement neque.. . cēdēbant is so. ${ }^{6}$ continēbant: kept. 
${ }^{7}$ scientiā: sciēns $\left(\right.$ sciō) + ia. ${ }^{8}$ singulās: what word is understood? ${ }^{9}$ propius: it was better for the Massilians to fight without the risk of being boarded. ${ }^{10}$ cum: not only. ${ }^{11}$ tarditāte: tardus + tās. 12 gravitāte: think of the derivation. 13 trānscendēbant: compare the verb ascendō and note the prefix trāns. 11 novem: with nāvēs.

Think of English words from cōnflīgunt, cēdēbant, excitātī, scientiā, cōnfīsī, circumvenìre, artificiis, and observe how the English word retains the meaning of the Latin.

\section{EXERCISE XLVI}

Grammar: A. $3 \delta_{2}, 1$; $3 \delta_{3} ; 3 S_{4} ; 506$. B. I 9I, 2 ; I92, I ; 338,3 . G. 356 , N. I ; $359 ; 432$, R. H. $433 ; 434,2 ; 628$.

Inflection: hortor; porta ; certior; hic.

Order of words: the beginning of the sentence is a place of emphasis. Prescribed list :

$\begin{array}{llll}\text { aggerem } & \text { aditus } & \text { subsidiō } & \text { cursum } \\ \text { vīneās } & \text { valle } & \text { appulsīs } & \text { magnopere } \\ \text { turrīs } & \text { māteriam } & \text { repentinum } & \text { hortātur } \\ \text { portūi } & \text { exstruit } & \text { dēdūcit } & \text { rūrsus } \\ \text { portam } & \text { classe } & & \end{array}$

\section{THE ROMANS PREPARE TO STORM MASSILIA}

Dum haec ${ }^{1}$ in Hispāniā geruntur, Gāius Trebōnius lēgātus, quī ad oppugnātiōnem Massiliae relictus erat, duābus $\mathrm{ex}^{2}$ partibus aggerem, vinneās, turrīsque ad oppidum agere īnstituit. Ūna erat proxima portuī nāvālibusque, altera ad portam quā est aditus ex Galliā atque Hispāniā, ad id mare quod adiacet ad ōstium Rhodanī. Massilia enim ferē ex tribus oppidì partibus marī alluitur; reliqua quārta est, quae aditum habeat ab terrā. Huius quoque spatī pars ea quae ad arcem pertinet, locī nātūrā et valle altissimā mūnìta, longam et difficilem ${ }^{3}$ habet oppugnātiōnem. Ad ea perficienda opera Gāius Trebōnius magnam iūmentōrum atque hominum multitūdinem ex omnī prōvinciā vocat ${ }^{4}$; vìmina māteriamque comportārī jubet. Quibus comparātìs rēbus aggerem in altitūdinem pedum octōgintā exstruit. Interim Lūcius Nāsidius, ab Gnaeō 
Pompēiō cum classe nāvium sēdecim, in quibus paucae erant aerātae, Lūciō Domitiō Massiliēnsibusque subsidiō missus, fretō ${ }^{\bar{y}}$ Siciliae imprūdente atque inopīnante Cūriōne ${ }^{6}$ pervehitur, appulsīsque Messānam ${ }^{7}$ nāvibus, atque inde propter repentīnum terrōrem prīncipum ${ }^{8}$ ac senātūs fugā factā, nảvem ex nāvālibus eōrum dēdūcit. Hāc adiūnctā ${ }^{9}$ ad reliquās nāvīs cursum Massiliam versus ${ }^{10}$ perficit, praemissāque clam nāviculā ${ }^{11}$ Domitium Massiliēnsisque dē suō adventū certiōrēs facit eōsque magnopere hortātur ut rūrsus cum Brūtī ${ }^{12}$ classe additīs suìs auxiliìs ${ }^{13}$ cōnflīgant.

De Bello Civili, II, i, 3

\section{VOCABULARY}

nāvālia, ium, n., dockyard

mare, is, n., sea (marine)

adiaceō, 2, uī, _. lie near.(adjacent)

ōstium, ōstī, n., mouth

alluō, $3, \mathrm{u} \overline{\mathrm{i}}, \longrightarrow$, wash

arx, arcis, f., citadel

iūmentum, i, n., beast of burden

vìmen, inis, n.. withe aerātus, a, um, bronze-covered fretum, i, n., strait imprūđēns, imprūdentis, off one's guard

inopīnāns, inopinantis, not $e x$ pecting

cōnflīgō, 3, flīxī, flīctus, contend with (conflict)

\section{NOTES}

${ }^{1}$ haec: the defeat of Cæsar's enemies. 2 ex: on. ${ }^{3}$ difficilem: compare with difficultās and with facilis. ${ }^{4}$ vocat: synonym of appellō. ${ }^{5}$ fretō: shows place. $\quad{ }^{6}$ Cūriōne: the proprætor of Sicily. $\quad{ }^{7}$ Messānam: the city of Messina. $\quad{ }^{8}$ prīncipum: with fugā. ${ }^{9}$ adiūnctā : ad + iungō. ${ }^{10}$ versus: toziarl. This preposition follows the word which it governs. 11 nāviculā: nāvis + cula, littli. ${ }^{12}$ Brūtī : the commander of Cæsar's fleet. ${ }^{13}$ additis . . . auxiliis : states a reason for cōnfligant.

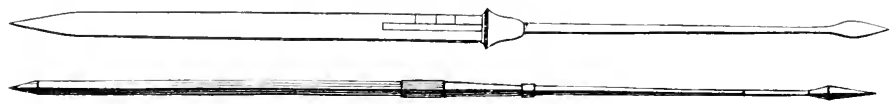




\section{EXERCISE XLVII}

Grammar: A. 349, $a$; 452, 1: 506:563. B. 204, 1: 330:338, 3 ; 295 , I. G. $37+; 422 ; 432$, R. ; 546 . H. $450 ;+51 ; 62 S ; 565$.

Inflection: contendō: tempus; superus (compare).

Order of words: an emphatic genitive depending on an adjective is usually placed before it.

Prescribed list:

$\begin{array}{llll}\text { refēcerat } & \text { dēfuit } & \text { gubernātōrum } & \text { iniectīs } \\ \text { remānserat } & \text { paulō } & \text { nactī } & \text { classe } \\ \text { prōiectì } & \text { paulātim } & \text { ferreīs } & \text { profūgit }\end{array}$

BRUTUS, AT THE HEAI) OF THE ROMAN FLEET, ENGAGES BATTLE WITH THE SHIPS OF THE MASSILIANS

Eōdem ${ }^{1}$ Brūtus contendit auctō nāvium numerō. Nam ad eās quae factae erant Arelāte² per Caesarem captìvae Massiliēnsium accesserant sex. Hās superiōribus diēbus refēcerat atque omnibus rēbus instrūxerat. Itaque suōs cohortātus, quōs ${ }^{3}$ integrōs superāvissent, ut victōs contemnerent, plēnus speì bonae atque animī adversus eōs proficīscitur. Facile erat ex castrīs Gāì 'Trebōnī atque omnibus superiōribus locīs prōspicere in urbem, ut ${ }^{4}$ omnis iuventūs, quae in oppidō remānserat, omnēsque superiōris aetātis cum lỉberīs atque uxōribus püblicissque custōdīis aut ex mūrō ad caelum manūs tenderent, ${ }^{5}$ aut templa deōrum immortālium adirent et ante simulācra prōiectī victōriam ab hīs exposcerent. ${ }^{6}$ Commissō proeliō Massiliēnsibus ${ }^{\top}$ rēs nūlla ad virtūtem dēfuit ; sed memorēes ${ }^{8}$ eōrum praeceptōrum quae paulō ante ab suīs accēperant, hōc ${ }^{9}$ animōo dēcertābant ut nüllum aliud tempus ad cōnandum habitūrī vidērentur. Dìductìsque $^{10}$ nostrìs paulātim nāvibus et artificiō gubernātōrum et mōbilitātỉ nāvium locus dabātur, et sĩ quandōo ${ }^{11}$ nostrī facultātem nactī ferreīs manibus ${ }^{12}$ iniectīs nāvem religāverant, undique suīs labōrantibus ${ }^{13}$ succurrēbant. Ex Massiliēnsium classe quinque sunt dēpressae, quattuor captae, ūna cum Nāsidiānīs profūgit.

De Bello Civili, II, 5, 6, 7 


\section{VOCABULARY}

integer, gra, grum, fiesh

contemnō, 3 , tempsī, temptus, $d e$ -

spise

plēnus, a, um, full (plenty)

prōspiciō, 3. spexī, spectus, look

forth

iuventūs, ūtis, f., youth (juvenile)

aetās, ātis, f., age

uxor, ōris, f., wife custōdia, ae, f., guard (custody)

caelum, i, n., sky

deus, ì, m.. god

simulācrum, $\overline{1}, \mathrm{n}$.. image

praeceptum, i, n., order

artificium, artifi'cī, n., skill

mōbilitās, ātis, f., mor'ing

religō, I, srapple

succurrō, 3 , curri, cursum, nush to helf

\section{NOTES}

1 eōdem: i.e. to Taurois, a fortress of the Massilians.

2 Arelāte: Arelas, a town near Massilia. ${ }^{3}$ quōs : understand eōs as the antecedent, with which victōs agrees. ${ }^{4}$ ut: how'. ${ }^{5}$ tenderent: think of the compound extenderent. $\quad{ }^{6}$ exposcerent: synonym of poscō. $\quad 7$ Massiliēnsibus : depends on dēfuit. ${ }^{8}$ memorēs: adjective. Think of memoria. ${ }^{9}$ hōc: such. $\quad{ }^{10}$ diductis : di, apart, + dīcō. $\quad{ }^{11}$ quandō: at any'time. $\quad{ }^{12}$ manibus: frongs, i.e. like hooked fingers. ${ }^{13}$ labōrantibus: translate by a clause.

Observe the force of the prefix in refēcerat, remānserat, adirent, prōiectī, dēfuit, accēperant.

\section{EXERCISE XIVIII}

Grammar: A. 3S2. I ; 504: 55S: 563. B. 191. 2: 33S. 1 : 295. I, 3 . G. $356: 428: 555$. I : 546. H. $433 ; 626 ; 595,2$; 565 .

Inflection: ferō; opus; nūllus.

Order of words: a complementary infinitive usually precedes the rerb on which it depends.

Prescribed list:

$\begin{array}{llll}\text { legiōnārī̄s } & \text { humilem } & \text { moram } & \text { docent } \\ \text { administrābant } & \text { hinc } & \text { quōminus } & \text { praedae } \\ \text { crēbrīs } & \text { saxa } & \text { nūtum } & \text { generis } \\ \text { èruptiōnibus } & \text { īnfima } & \text { vēstīgiō } & \text { prōnūntiantur } \\ \text { turrim } & & & \end{array}$


THE ROMANS BUILD A TOWER AND UNDERMINE A TURRET OF THE MASSILIANS, WHO PLEAD FOR MERCY

Massiliēnsēs nihilō ${ }^{1}$ sētius ${ }^{2}$ ad dēfēnsiōnem ${ }^{3}$ urbis reliqua apparāre ${ }^{4}$ coepērunt. Est animadversum ab legiōnāriìs qui dextram partem operis administrābant, ex crēbrīs hostium ēruptiōnibus, magnō sibi esse praesidiō posse sī ibi prō castellō ac receptāculōo turrim ex latere sub mūrō fēcissent. Quam primō ad repentinōs incursūs humilem parvamque fēcērunt. Hūc sē referēbant; hinc, sì qua maior oppresserat vīs, prōpugnābant ${ }^{5}$; hinc ad repellendum et prōsequendum hostem prōcurrēbant. Posteā vērō, ut ${ }^{\hat{i}}$ est rērum omnium magister ūsus, ${ }^{7}$ inventum est ${ }^{8}$ magnō esse ūsuī posse sī haec esset in altitūdinem turris ēlāta. ${ }^{9}$ Id perfectum est. Ex eā turrī mūsculum pedēs sexāgintā longum ad hostium turrim mūrumque facere instituêrunt. Hoc opus omne tēctum vineīs ad turrim hostium admovent, ut aedificiō iungātur. Quō malō perterritī subitō oppidānī ${ }^{10}$ saxa in mūsculum dēvolvunt. Interim sub mūsculō mìlitēs īnfima saxa turris hostium convellunt. Nōn datur lībera mūrī dēfendendī facultās. Complūribus lapidibus turrī subductīs repentinā ruīnā pars eius turris concidit, cum hostēs urbis dīreptiōne perterritī inermēs ad lēgātōs atque exercitum supplicēs manūs tendunt. Quāa novā rē oblātā ${ }^{11}$ omnis administrātiōo ${ }^{12}$ belli cōnsistit mìlitēsque āversī à proeliō ad studium audiendī et cognōscendī feruntur. Ubi hostēs ad lēgātōs exercitumque pervēnērunt, ūniversì sē ad pedēs prōiciunt; ōrant ut adventus Caesaris exspectētur. Captam ${ }^{13}$ suam urbem vidēre ${ }^{14}$; opera perfecta, turrim subrutam; itaque ab dēfēnsiōne dēsistere. Nūullam exorīin̄i ${ }^{15}$ moram posse quōminus, ${ }^{16}$ cum vēnisset, sī imperāta ${ }^{17}$ nōn facerent ad nūtum, è vēstīgiō diriperentur. ${ }^{18}$ Docent, sī omnīnō turris concidisset, nōn posse militēs continēri quīn spē praedae in urbem irrumperent urbemque dēlērent. Haec atque eiusdem generis complūra, ut ab hominibus doctīs, ${ }^{19}$ magnā cum misericordiā flētūque ${ }^{20}$ prönūntiantur. - DE Bello Civili, II, 8, I O, I 2 


\section{VOCABULARY}

receptãculum, i, n., place of refuge later, eris, m., brick

incursus, ūs, m., onset

prōcurrō, 3, currī, cursum, nun forth magister, trī, m., master, teacher mūsculus, $\overline{1}, \mathrm{~m}$., covered passageway tegō, 3, tēxī, tēctus, protect vinea, ae, f., shed dēvolvō, 3 , volvī, volūtus, roll dow'n convellō, 3 , vellī, vulsus, loosen concidō, 3, cidī, _- collapse direptiō, ōnis, f., pillage tendō, 3 , tetendi, tentus, extend subruō, 3 , ruī, rutus, undermine urbs, urbis, f., city irrumpō, 3 , rūpi, ruptus, burst into dēleō, 2, lēvī, lētus, destroy misericordia, ae, f., wretchedness

\section{NOTES}

${ }^{1}$ nihilō: $=$ nihil. $\quad{ }^{2}$ sētius $:=$ minus. $\quad{ }^{3}$ dēfēnsiōnem $:$ dēfendō + tiōo. ${ }^{4}$ apparāre: ad + parō. $\quad{ }^{5}$ prōpugnābant: observe the prefix. ${ }^{6}$ ut: as. 7 üsus: experience. ${ }^{8}$ inventum est: in, upon, + veniō. English derivative? $\quad{ }^{9}$ èlāta esset: ex + ferō. $\quad{ }^{10}$ oppidānī: oppidum + ānus, belonging to. 11 oblātā: from offerō. English derivative? ${ }^{12}$ administrātiō: administrō + tiō. ${ }^{13}$ captam : indirect discourse depending on vidēre. ${ }^{14}$ vidēre: indirect discourse depending on the idea of saying implied in ōrant. 15 exorīì : synonym of orior. ${ }^{16}$ quōminus : so that ...not. 17 imperāta: neuter participle of imperō, used as a noun. ${ }^{18}$ diriperentur: the same root is found in the noun direptiō. $\quad{ }^{19}$ doctis : learned, ironical with ut. $\quad{ }^{20}$ flètū: a verbal noun from flē̄.

\section{EXERCISE XLIX}

Grammar: A. 410; 53I : 546; 558. В. 2I 8, I ; 282, I; 288, I, B ; 295 , 3. G. 407 ; 545 , I, $3 ; 585 ; 555$, I. H. $477 ; 568 ; 600$, II, I ; $595,2$.

Inflection: possum : turris : quīdam : aegrēe (compare).

Order of words: the adverb is usually placed immediately before the word which it modifies.

\section{Prescribed list:}

dēdūcunt

oppugnātiōne

genere

remittunt at

occāsiōnem

aliquot

portis ventō

sagittīs

fugientīs

tempestātis nactī

aggerem

ēruptiōne

reficere 
THE MASSILIANS DISREGARD THE TRUCE AND SET FIRE TO THE SIEGEWORKS OF THE ROMANS

Quibus rēbus ${ }^{1}$ commōtī lēgātī mìlitēs ex opere dēdūcunt, oppugnātiōne dēsistunt; operibus custōdiās relinquunt. Indūtiārum quōdam genere misericordiā ${ }^{2}$ factō adventus Caesaris exspectātur. Nūllum ex mūrō, nūllum ā nostrīs mittitur tēlum; ut ${ }^{3}$ rē cōnfectā, omnēs cūram et dīligentiam remittunt. Caesar enim per litterās Trebōniō magnō opere ${ }^{4}$ mandāverat nē per vim oppidum expugnārì paterētur, nē gravius permōtī mīlitēs et dēfectiōnis odiō et contemptiōne sū̄ ${ }^{5}$ et diūtino ${ }^{6}$ labōre omnīs pūberēs interficerent ; quod ${ }^{7}$ sē factūrōs minābantur, aegrēque tunc sunt retentī quīn oppidum irrumperent, graviterque eam rem tulērunt, quod stetisse per Trebōnium quōminus oppidō potīrentur vidēbātur. At hostēs sine fidē tempus atque occāsiōnem fraudis ac dolì quaerunt, interiectīsque $^{8}$ aliquot diēbus, subitō merīdiānō tempore, cum alius discessisset, alius ex diūtinō labōre in ipsīs operibus quiētī sē dedisset, arma vērō omnia reposita ${ }^{9}$ contēctaque essent, portīs forās ērumpunt, ${ }^{10}$ secundō magnōque ventō ìgnem operibus inferunt. Nostrī repentīnā fortūnā permōtī arma quae possunt arripiunt; alī ex castrīs sēsē incitant. Fit in hostīs impetus eōrum, sed dē mūrō sagittīs tormentìsque fugientīs persequī ${ }^{11}$ prohibentur. Ita multōrum mēnsium labor hostium perfidiā et vī tempestātis pūnctō temporis interiit. Temptāvērunt hoc idem Massiliēnsēs posterō diē. Eandem nactī tempestātem maiōre cum fīdūciā ${ }^{12}$ ad alteram turrim aggeremque ēruptiōne pugnāvērunt multumque ignem intulērunt. Sed ut superiöris temporis contentiōnem ${ }^{13}$ nostrī omnem remiserant, ${ }^{14}$ ita proximī diēì cāsū admonitīi ${ }^{1 \bar{s}}$ omnia ad dēfēnsiōnem parāverant. Itaque multīs interfectīs reliquōs infectā ${ }^{16}$ rē in oppidum reppulērunt. Trebōnius autem ea quae sunt āmissa multō maiōre mīlitum studiō administrāre et reficere īnstituit. Nam ubi tantōs suōs labōrēs cecidisse vīdērunt, aggerem novī generis aequā ferē altitūdine fēcerunt. Celeriter rēs administrātur. Portae ēruptiōnis causā in mūrōo relinquuntur. - DE Bello Civili, II, I 3 , I 4, I 5 


\section{VOCABULARY}

custōdia, ae, f., guard

indūtiae, ārum, f., truce

misericordia, ae, f., pity

cūra, ae, f., care

dēfectiō, ōnis, f., rer'olt

odium, odi, n., strong dislike

pūberēs, um, m., adults

minor, I, threaten

irrumpō, 3, rūpī, ruptus, break into stō, I, stetī, statum, stand, (with per)

stand to one's account dolus, i, m.. trickery

merīiānus, a, um, of midday

contegō, 3 , tēxī, tëctus, con'er

forās, forth

arripiō, 3, ripui, reptus, seize

tormentum, i, n., hurling machine

perfidia, ae, f., treachery

pūnctum, i, n., moment

intereō, + , ii, itum, perish

\section{NOTES}

1 quibus rēbus: the fall of a great tower which the Massilians had erected. 2 misericordiā: states the cause of factō. ${ }^{3}$ ut: as. ${ }^{4}$ magnō opere: has the force of an adverb. 5 sui : shown to them. To whom does sui refer? ${ }^{6}$ diūtinō: diū + tinus, a time suffix. ${ }^{7}$ quod: refers to the preceding clause. 8 interiectis: observe the composition. ${ }^{9}$ reposita: observe the composition. ${ }^{10}$ erumpunt: compare with irrumpō. 11 persequĩ: observe the composition. 12 fïdūciāa synonym of fidès. 13 contentiōnem: English derivative? ${ }^{14}$ remīserant: had gièen uf. 15 admonitĩ : composition? 16 infectā: composition?

Observe the position of the adverbs in the passage, and determine the reason for the exceptions to the rule stated above.

\section{EXERCISE I.}

Grammar: A. 3S2. I ; tIt: 4 S9: t96. H. I9I, I ; 223: 336 , I ;

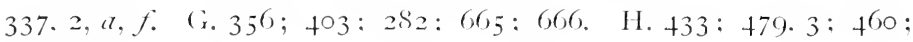
$63 \$, 1$.

Inflection: trādō ; auxilium : gravis : ipse.

Order of words: adjectives of quantity usually precede the nouns which they modify.

Prescribed list:

$\begin{array}{llll}\text { dēfessī } & \text { ēruptiōnibus } & \text { familiāribus } & \text { portum } \\ \text { bis } & \text { victūs } & \text { cōnscenderat } & \text { ancorīs } \\ \text { crēbrīs } & \text { dēdere } & \text { nactus } & \text { cōnspectū }\end{array}$


THE MASSILIANS, BESET BY MISFORTLNE, SLRRENIDER

Massiliēnsēs omnibus dēfessī malīs, reĩ frūmentāriae ad summam inopiam adducti, bis nāvālī ${ }^{1}$ proeliō superāti. crēbrīs ēruptiōnibus fūsì, gravì etiam pestilentiā ${ }^{2}$ cōnflìctātī ex diūtină ${ }^{3}$ conclūsiōne et mūtātiōne vịctūs (pānicō enim vetere atque hordeō corruptō omnēs alēbantur, quod ad huius modì cãsūs ${ }^{4}$ antīquitus ${ }^{5}$ parātum in pūblicum ${ }^{6}$ contulerant), dēiectã turrī, labefactā magnā parte mūrī, auxilì̄s prôxinciārum et exercitum dēspērātīs. '̄ quōs in Caesaris potestātem rēnisse cognōverant, sēsē dēdere sine fraude cōnstituunt. Sed paucīs ante ${ }^{s}$ diēbus Lūcius I )omitius cognitā Massiliènsium voluntāte, nāvibus tribus comparātīs, ex quibus duās familiāribus suîs attribuerat, ūnam ipse cōnscenderat, nactus turbidam tempestātem profectus est. Hunc cōnspicātae nāiēes, quae missū ${ }^{9}$ Brūtī cōnsuētūdine cotìdiānā ad ${ }^{10}$ portum excubābant, sublātīs ancorīs, sequī coepērunt. Ex hìs ūnum ipsīus nāvigium ${ }^{11}$ contendit et fugere perserēerārit ${ }^{12}$ auxiliōque tempestātis ex cōnspectū abiit, ${ }^{13}$ duo perterrita ${ }^{14}$ concursū nostrārum nāvium sēsé in portum recēpērunt. Massiliēnsēs arma tormentaque ex oppidō, ut est imperātum, prōferunt, nāvīs ex portū nāvālibusque èdūcunt, pecūniam ex pūblicō trādunt. Quibus rēbus cōnfectīs, Caesar, magis eōs prō nōmine et vetustāte ${ }^{1 \overline{5}}$ quam prō meritìs in sē cìvitātis cōnservāns, duās ibi legiōnēs praesidiōo ${ }^{16}$ relíquit. - De Bello Civili, II, 22

\section{VOCABULARY}

malum, ì, n., iril

fundō, 3, fūdì, fūsus, rout cōnflictātus, a, um, tormentéd conclūsiō, ōnis, f., blockade mūtātiō, ōnis, f., chunge pānicum, ì, n., millet hordeum, i, n., barley corruptus, a, um, damaged alō, 3, uī, tus, fièl labefactus, a, um, shaken fraus, fraudis, f., diception attribuō, 3, uī, ūtus, assign turbidus, a, um, boisterous tempestās, ātis, f., w'êther excubō, I, kêtp wutich tormentum, i, n., hurling mathine nāvālia, ium, n.. dockụverd pecūnia, ae, f.. money cōnservō, I, sar'c 


\section{NOTES}

1 nāvālī: nāvis +ālis, bclonging to. 3 diūtina: diū + tinus, a time suffix. adverb from antiquus, synonym of vetus. ‘ dēspērātīs: dē + spērō. English derivative?

2 pestilentiā: English derivative? ${ }^{4}$ cāsūs: chances. $\quad{ }^{5}$ antīquitus: verbal noun from mittō. $1{ }^{10}$ ad: near. 11 nāvigium: synonym of nāvis. 12 persevērāvit: English derivative? ${ }^{13}$ abiit: composition? ${ }^{14}$ perterrita: nāvigia is understood. ${ }^{15}$ vetustāte: vetus + tās. ${ }^{16}$ praesidiōo states what the legionès were for.

Determine which of the participles in the passage denote time and which denote cause.

\section{EXERCISE LI}

Grammar: A. 504, b; $540 ; 549$. B. $338,1, c ; 286$, I, 2. G. 428,2 ; $540 ; 586$. H. 475,$2 ; 588, \mathrm{I} ; 59$.

Inflection: volō; equitātus: ipse.

Order of words: an adjective usually is placed immediately before or after the word which it modifies, unless a limiting word or phrase intervenes.

\section{GALBA IS STATIONED IN THE ALPS TO KEEP THE ROADS OPEN}

Cum in İtaliam proficīscerētur Caesar, Servium Galbam cum legiōne duodecimā et parte equitātūs in Nantuātīs, ${ }^{1}$ Veragrōs, Sedūnōsque mīsit, quī ā fīnibus Allobrogum et lacū Lemannō et flūmine Rhodanō ad summās Alpīs pertinent. Causa mittendī fuit quod $^{2}$ iter $^{3}$ per Alpiss, quō magnō cum perīculō magnisque cum portōrī̄s mercātōrēs ire cōnsuērant, patefierī volēbat. $\mathrm{Huic}^{4}$ permīsit, sī opus esse arbitrārētur, utī in hìs locīs legiōnem hiemandī causā collocāret. Galba secundīs aliquot ${ }^{5}$ proeliīs factīs castellīsque complūribus eōrum expugnātīs, missìs ad eum undique lēgātīs obsidibusque datīs et pāce factā, cōnstituit cohortīs duās in Nantuātibus collocāre et ${ }^{6}$ ipse cum reliquīs eius legiōnis cohortibus in vīcō Veragrōrum, quī appellātur Octodūrus, hiemāre ; quī vīcus positus 
in valle, nōn magnā adiectā plānitiē, altissimìs montibus undique continētur. Cum hìc in duās partīs flūmine dīviderētur, ${ }^{\top}$ alteram partem eius vìcī Gallis concessit, alteram vacuam ${ }^{8}$ ab hìs relictam cohortibus attribuit. Eum locum vāllō fossāque mūnīvit.

De Bello Gallico, III, I

\section{VOCABULARY}

duodecimus, a, um, twelfth

quō, whither

portōria, ōrum, n., customs duties

patefaciō, 3 , fēcī, factus, throw open arbitror, 1, think adiciō, 3 , iēcī, iectus, lie near to plānitiēs, èì, f., plain vacuus, a, um, empty' (vacuum) attribuō, 3, uī, ùtus, assign

\section{NOTES}

1 Nantuātis, etc.: for the location of these tribes, consult the map. ${ }^{2}$ quod, etc.: this clause explains causa. ${ }^{3}$ iter: the voice of patefieri shows that iter must be subject. ${ }^{4}$ huic: refers to Galba. ${ }^{5}$ aliquot: indeclinable. ${ }^{6}$ collocāre et: what word does et connect with collocāre? ${ }^{7}$ cum ... dividerêtur: states the reason for concessit and attribuit. 8 vacuam: predicate adjective with relictam.

Observe the position of the adjectives in the passage with reference to the words which they modify.

\section{EXERCISE LII}

Grammar: A. 569, 2: 579: 580. B. 297, 2:313:314, I. G. 553,3: $648 ; 650$. H. 571, 1; 641:642:643.

Inflection: ē̄; diēs; omnis.

Order of words: a preposition regularly precedes the word which it governs.

THE MOUNTAIN TRIBES RENEW TIE WAR AND OVERPOWER TIE ROMAN SOLDIERS

Cum diēs hỉbernōrum complūrēs trānsīssent frūmentumque ${ }^{1}$ eō comportārī iussisset, subitō per explōrātōrēs certior factus est ex eā parte vìcī quam Gallīs concesserat omnīs noctū ${ }^{2}$ discessisse, 
montīsque $^{3}$ quī impendērent ā maximā multitūdine Sedūnōrum et Veragrōrum tenērī. Id aliquot dē causīs acciderat, ut subitō Galli bellī renovandī legiōnisque opprimendae cōnsilium caperent: prīmum, quod ${ }^{4}$ legiōnem, neque eam ${ }^{5}$ plēnissimam dētrāctīs cohortibus duābus et complūribus singillātim quī commeātūs petendī causā missĩ erant absentibus, propter paucitātem ${ }^{6}$ dēspiciēbant; tum etiam, quod propter iníquitātem ${ }^{7}$ locī, cum ipsī ex montibus in vallem dēcurrerent et tēla conicerent, nē prīmum quidem impetum suum posse sustinērī̄ exīstimābant. Accēdēbat quod suōs ab sē lỉberōs abstrāctōs obsidum nōmine ${ }^{9}$ dolēbant, ${ }^{10}$ et Rōmānōs nōn sōlum itinerum causā sed etiam perpetuae possessiōnis ${ }^{11}$ culmina Alpium occupāre cōnārī et ea loca finitimae prōvinciae ${ }^{122}$ adiungere sibi persuāsum habēbant. ${ }^{13}$ - De Bello Gallico, III, 2

\section{VOCABULARY}

ēo, thither

impendē, 2, —, - orerhang

plēnus, a, um, full

singillātim, one at a time abstrahō, 3, trāxī, trāctus, draco aw'ay from

culmen, inis, n., summit

\section{NOTES}

${ }^{1}$ frūmentum: the voice of comportāri shows that this cannot be its object. ${ }^{2}$ noctū : = nocte. $\quad{ }^{3}$ montis: for the syntax, observe the voice of tenerri. ${ }^{4}$ quod, etc.: a clause which explains causis. How many other reasons does Cæsar give? $\quad{ }^{5}$ eam: refers to legiōnem. $\quad{ }^{6}$ paucitātem: paucī + tās. ${ }^{7}$ inīquitātem : in + aequus + tās. ${ }^{8}$ sustinērì : complementary infinitive. ${ }^{9}$ nōmine: under the name. ${ }^{10}$ dolēbant: an indirect statement depends on it. ${ }^{11}$ possessiōnis: understand causā. 12 prōvinciae: for the case, consider adiungere. $\quad{ }^{13}$ sibi persuāsum habēbant: were persuaded.

Think of English words from factus, concesserat, impendērent, acciderat, renovandî, dêspiciēbant, culmina, adiungere, and observe how the English word retains the meaning of the Latin. 


\section{EXERCISE LIII}

Grammar: A. $346, a, 3 ;$ 409. a: +20.1, 2: 45+. B. 201. 2 ; 218,8 ; 227, 2, a, d: 330. G. $369 ;+05: 410 ;+22,4$. H. $+42: 477, \mathrm{II} ;+89,1$; $6 \mathrm{I} 5, \mathrm{I}$.

Inflection: possum: salūs; celeriter (compare).

Order of words: a dependent genitive, unless emphatic, normally follows the noun which it limits.

A COUNCIL IS CALLEI TO CONSIDER WAYS OF MEETING THE IMPENDING DANGER

Hìs nūntiīs acceptīs Galba, cum neque opus hỉbernōrum mūnītiōnēsque plēnē essent perfectae neque dē frūmentō reliquōque commeātū satis esset prōvìsum, ${ }^{1}$ quod ${ }^{2}$ dēditiōne factā obsidibusque acceptīs nihil dē bellō timendum ${ }^{3}$ exīstimāverat, cōnsiliō celeriter convocātō sententiās exquīrere ${ }^{4}$ coepit. Quōo in cōnsiliō, cum tantum repentīnī perīculī praeter opīniōnem accidisset, ac iam omnia ferē superiōra loca multitūdine armātōrum complēta ${ }^{\circ}$ cōnspicerentur, neque subsidiō venīrī ${ }^{6}$ neque commeātūs supportārī î interclūsīs itineribus possent, prope iam dēspērātā ${ }^{8}$ salūte nōn nūllae eius $\bmod ^{9}{ }^{9}$ sententiae dīcēbantur, ut impedīmentīs relictīs, ēruptiōne factā, îsdem itineribus quibus eō pervēnissent ad salūtem contenderent. ${ }^{10}$ Maiōrī tamen partī ${ }^{11}$ placuit ${ }^{12}$ hōc reservātō ad extrēmum cāsum cōnsiliō interim reì ēventum experīrì et castra dēfendere. - I)e Bello Gallico, III, 3

\section{VOCABULARY}

plēnē, fully.

placēo, 2, uī, itum, please

ēo, thither

\section{NOTES}

1 esset prōvisum: impersonal. ${ }^{2}$ quod: conjunction. ${ }^{3}$ timendum: what is understood? Consider the finite verb of the clause. 4 exquirere: ex + quaerō. $\quad{ }^{5}$ complēta : predicate adjective. ${ }^{6}$ venīrī: understand 
posset, used impersonally. i supportāri : sub, "uf to, t portō. $\quad 8$ dēspērātā: composition? 9 modī: descriptive genitive. ${ }^{10}$ contenderent: states the purpose of sententiae diceibantur. ${ }^{11}$ parti: for the case, consider the verb. 12 placuit: impersonal.

Find the phrases in the passage which contain a genitive, observe in each case the position of the genitive, and determine the reason for the position.

\section{EXERCISE LIV}

Grammar: A. $400: 401: 418: 4^{6} 3$. B. 21 $4,1, b ; 226: 335$. G. 405 ; $397: 647$. H. $462: 480: 610$.

Inflection: dō: brevis; suī.

Order of words: an adverb normally is placed before the word which it limits.

OUR MEN, ATTACKED BI THE ENEMY, ARE AT A DISAINANTAGE BECALSE OF TIIEIR SMALL NLMBERS

Brevī spatiō interiectō, vix ut īs rēbus ${ }^{1}$ quās cōnstituissent collocandīs atque administrandīs tempus darētur, hostēs ex omnibus partibus signō datō dēcurrere, ${ }^{2}$ lapidēs gaesaque in vāllum conicere. Nostrī prīmō integrīs vìribus fortiter prōpugnāre neque ūllum frūstrā tēlum ex locō superiōre mittere, et quaecumque pars castrōrum nūdāta dēfēnsōribus ${ }^{3}$ premī vidēbātur, eō occurrere et auxilium ferre: sed hōc ${ }^{4}$ superārī, quod ${ }^{5}$ diūturnitāte pugnae hostës dēfessī proeliō excēdēbant, alìi integrīs vìribus succēdēbant, quārum rērum à nostrīs propter paucitātem ${ }^{6}$ fierī nihil poterat, ac nōn modo dēfessōi ex pugnā excēdendì sed nē sauciō quidem eius locì ubi cōnstiterat relinquendī ac suī recipiendì facultās dabātur.

$$
\text { De Bello'Gallico, III, } 4
$$

\section{VOCABULARY}

intericiō, 3. iēcī, iectus, interrene gaesum, i, n., jacelin integer, gra, grum, fresh dēfēnsor, ōris, m., defender diūturnitās, ātis, f., long duration 


\section{NOTES}

1 rēbus: for the case, consider the verb of the clause. ${ }^{2}$ dẽcurrere: historical infinitive, used in lively narrative instead of the indicative. The passage contains several other examples of this use of the infinitive. 3 dēfēnsōribus: with nūdāta. $\quad{ }^{4}$ hōc: ablative of respect. $\quad{ }^{5}$ quod: conjunction. $\quad{ }^{6}$ paucitātem: paucī + tās. ${ }^{7}$ dēfessō: understand hominī. Take with dabātur. ${ }^{8}$ suī : refers to sauciō.

Think of English words from brevī, tempus, omnibus, integris, frūstrā, superiōre, succēdēbant, poterat, and observe how the Latin word helps to make plain the meaning of the English derivative.

\section{EXERCISE LV}

Grammar: A. 282; 345; 563. B. 169, 1; 203, I ; 295, 1. G. 320 ; $365 ; 546$. H. $393 ; 440,3 ; 565$.

Inflection: faciō; vīs; certior.

Order of words: a common arrangement of the parts of the predicate, unless modified by the general rule of emphasis, is : indirect object, direct object, adverb, verb.

\section{THE ROMANS DECIDE TIIAT IN A SALLY LIES THEIR ONLY HOPE OF RELIEF}

Cum iam amplius hörīs ${ }^{1}$ sex continenter pugnārētur ${ }^{2}$ ac nōn sōlum vīrēs sed etiam tēla nostrōs dēficerent, atque hostēs ācrius instārent languidiōribusque ${ }^{3}$ nostrìs vāllum scindere et fossās complēre coepissent, rēsque esset iam ad extrēmum perducta ${ }^{4}$ cāsum, Pūblius Sextius Baculus, prīmì pīlī centuriō, quem Nervicō proeliō complūribus cōnfectum ${ }^{5}$ vulneribus diximus, et item Gāius Volusēnus, tribūnus mīlitum, vir et cōnsilì magnī et virtūtis, ad Galbam accurrunt atque ūnam esse spem salūtis docent, sī ēruptiōne factā extrēmum auxilium experīrentur. Itaque convocātīs centuriōnibus celeriter militēs certiōrēs facit ${ }^{6}$ paulisper intermitterent proelium ac tantummodo tēla missa exciperent sēque ex labōre reficerent, post $^{7}$ datō signō ex castrīs ērumperent atque omnem spem salūtis in virtūte pōnerent. — De Bello Gallico, III, 5 


\section{VOCABULARY}

languidus, a, um, weary scindō, 3, scidī, scissus, split accurrō, 3, currī, cursum, run to ērumpō, 3, rūpī, ruptus, burst forth (eruption)

\section{NOTES}

${ }^{1}$ hōrīs: ablative with amplius. $\quad{ }^{2}$ pugnārētur, etc.: these verbs are in the subjunctive because the clauses describe the circumstances that go to make up the critical condition in which Galba finds himself. $\quad{ }^{3}$ languidiōribus: a part of the ablative absolute. $\quad{ }^{4}$ perducta: with esset. ${ }^{5}$ connfectum: what is understood? ${ }^{6}$ certiōeres facit: equivalent to a verb of commanding, the commands being expressed in the following subjunctives. ${ }^{7}$ post: adverb.

Select words in the passage which seem emphatic, and determine the reason for considering them so.

\section{EXERCISE LVI}

Grammar: A. 370; 4I9; 423. I ; 540. B. I 87 , III; 227; 230 ; 286, I. G. $347 ; 409 ; 393 ; 5$ 40. H. $429 ; 489 ; 486 ; 588,1$.

Inflection: fīō; alius.

Order of words: a demonstrative pronoun usually precedes the word which it modifies.

THE ROMANS BY A SALLY ROUT THE ENEMY AND RETURN TO THE PROVINCE

Quod $^{1}$ iussī sunt faciunt, ac subitō omnibus portīs ēruptiōne factā neque cognōscendì quid fieret neque suī ${ }^{2}$ colligendī hostibus facultātem relinquunt. Ita commūtātā fortūnā eōs quī in spem potiundōrum castrōrum vēnerant undique circumventōs ${ }^{3}$ interficiunt, et ex hominum mīlibus amplius trīgintā, quem numerum ${ }^{4}$ barbarōrum ad castra vēnisse cōnstābat, plūs tertiā parte interfectā reliquōs perterritōs in fugam coniciunt ac nē in lociss quidem superiōribus cōnsistere patiuntur. Sīc omnibus hostium cōpiīs fūsīs armīsque $^{5}$ exūtīs sē intrā mūnitiōnēs suās recipiunt. Quō proeliō factō, quod ${ }^{6}$ saepius fortūnam temptāre Galba nōlēbat, atque aliō̄ 
sē in hỉberna cōnsiliō vēnisse meminerat, aliīs occurrisse rēbus vīderat, maximē frūmentī commeātūsque inopiā ${ }^{8}$ permōtus posterō diè omnibus eius $\mathrm{vīc}^{9}$ aedificī̄s incēnsīs in prōvinciam revertī contendit, ac nūllō hoste prohibente aut iter dēmorante ${ }^{10}$ inco- $^{-}$ lumem legiōnem in Nantuātīs, inde in Allobrogēs perdūxit ibique hiemāvit. - De Bello Gallico, III, 6

\section{VOCABULARY}

colligō, 3, lēgī, lēctus, gather together fundō, 3, fūdī, fūsus, rout

(collection) exuō, 3, ūī, ūtus, strip

commūtō, I, change (commute)

meminī, isse (defective), remember

\section{NOTES}

1 quod: pronoun; understand facere. ${ }^{2}$ sui : refers to hostibus. ${ }^{3}$ circumventōs: translate as if it were a finite verb with the same form as interficiunt. ${ }^{4}$ numerum: subject of vēnisse. $\quad{ }^{5}$ armīs : ablative of separation. $\quad{ }^{6}$ quod: conjunction. ${ }^{7}$ aliō: note the emphasis. 8 inopiā: states the cause of permōtus. $\quad 9$ vīcì: a genitive often stands between an adjective and its noun. $\quad{ }^{10}$ dëmorante: synonym of moror。

\section{EXERCISE LVII}

Grammar: A. 345, a; +19, a; +23, 1, 2. B. 203, I ; 227, 1 ; 230; ISI, I. G. 365; 409; 393; 336. H. 440, 3; 489; $486 ; 417$.

Inflection: coepi ; opus ; exterus (compare).

Order of words: the limiting word or phrase, unless unemphatic, precedes the word which it limits.

The Veneti, a tribe occupying the seacoast northwest of the River Loire, form a union to resist the Romans. They have a strong navy and live in a section hard to invade. Cæesar understands the seriousness of the danger and orders a large fleet of war vessels to be built and equipped.

THE LOCATION OF THE TOWNS OF TIIE VENETI AND THEIR MEANS OF DEFENSE

Erant eius modī ferē sitūs oppidōrum ut posita $^{1}$ in extrēmīs lingulis prōmunturī̄sque ${ }^{2}$ neque pedibus aditum habērent cum ex alto $^{3}$ sê acstus incitāvisset, quod ${ }^{4}$ accidit semper hōrārum duodecim 
spatiō, neque nāvibus, quod rūrsus minuente aestū nāvēs in vadīs afflìctārentur.̄ I ta utrāque rē oppidōrum oppugnātiō impediēbātur. Ac sì quandò magnitūdine operis forte superātī, extrūsō marī aggere ac mōlibus atque hìs oppidī moenibus adaequātìs, dēspērāre ${ }^{6}$ fortūnìs suīs coeperant, magnō numerō nāvium appulsō, cuius reī summam facultātem habēbant, sua dēportābant ${ }^{\top}$ omnia sēque in proxima oppida recipiēbant; ibi sē rūrsus isdem opportūnitātibus locì dēfendēbant. Haec eō facilius magnam partem aestātis faciēbant, quod nostrae nāvēs tempestātibus dētinēbantur, ${ }^{9}$ summaque erat vāstō atque apertō marī, magnīs aestibus, rārīs ac prope nūlìs portibus, difficultās nāvigandì.-1) E Bello GAllico, III, I 2

\section{VOCABULARY}

situs, ùs, m., situation

lingula, ae, f.. little tongue (of land) semper, aladys quandō, at any time

extrūđō, 3, trūsī, trūsus, shut out vāstus, a, um, r'ast

\section{NOTES}

${ }^{1}$ posita: agrees with a pronoun referring to oppidorum and subject of habērent. ${ }^{2}$ prōmunturiis: English derivative? ${ }^{3}$ altō: the deep. ${ }^{4}$ quod: refers to the fact stated in the preceding clause. $\quad{ }^{5}$ afflictārentur: English derivative? ${ }^{6}$ dēspērāre: composition? ${ }^{7}$ dēportābant: composition? \& ē: for this reason. ${ }^{9}$ dētinēbantur: composition?

Observe the large number of examples of the ablative absolute in the passage and determine the best way to translate each one.

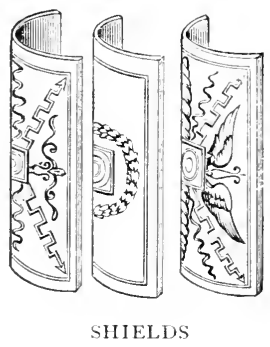




\section{EXERCISE LVIII}

Grammar: A. 414; $415 ; 506$. B. 223 ; 224; 33\&, 3. G. 403 : 400; 432, R. H. $479 ; 473,2 ; 62 S$.

Inflection: fīō; flūctus : plānior.

Order of words: a genitive, unless emphatic, follows the noun which it limits.

THE SHIPS OF THE VENETI ANI THEIR EQLIPMENT

Namque ipsōrum nāvēs ad hunc modum ${ }^{1}$ factae armātaeque erant: carīnae aliquantō plāniōrēs quam nostrārum nārium, ${ }^{2}$ quō ${ }^{3}$ facilius vada ac dēcessum aestūs excipere possent; prōrae ${ }^{+}$adnodum êrēctae atque iten puppēs, ad magnitūilinem flūctuum tempestātumque accommodātae; nāvēs tōtae factae ex rōbore ad quamvis vim et contumēliam perferendam; trānstra ex pedālibus ${ }^{5}$ in altitūdinem trabibus, cōnfìxa clāvīs ferreīs digitī pollicis ${ }^{6}$ crassi- $^{-}$ tūdine; ancorae prō fūnibus ferreìs catēnīs revinctae ${ }^{7}$; pellēs prō vēlīs alūtaeque tenuiter cōnfectae, ${ }^{8}$ sive propter inopiam linni atque eius ūsūs inscientiam ${ }^{9}$ sìve eô, quod est magis vērī simile, quod tantās tempestātēs Ōceanī tantōsque impetūs ventōrum sustinērì ac tanta onera nāvium regī vēlis nōn satis commodē posse arbitrābantur. ${ }^{10}$ - I)E Bello Gallico, III, 13

\section{VOCABULARY}

carina, ae, f., kecel

aliquantus, a, um, some, somcrihat dēcessus, ùs, m., $\iota b b$

prōra, ae, f., prow

admodum, i'ery muih

ērēctus, a, um, rerised

trānstrum, i, n., thwart cōnfixus, a, um, fixstened together clāvus, $\overline{1}$, m., nail crassitūđō, inis, f., thicklle'ss alūta, ae, f., licthe'r tenuiter, thimly sive ... sive, whether... or linum, i, n., line'l

\section{NOTES}

${ }^{1}$ modum: fashicun. $\quad{ }^{2}$ nāvium: understand carīnae. $\quad{ }^{3}$ quōo introduces a clause of purpose containing a comparative. ${ }^{4}$ prōrae: understand erant. ${ }^{5}$ pedālibus: $\overline{p e} \mathrm{~s}+\bar{a}$ lis, belonging to, of $a .{ }^{6}$ digitī pollicis : 
thumb. $\quad{ }^{7}$ revinctae $:$ re + vinciō. $\quad{ }^{8}$ cōnfectae: tanned. $\quad{ }^{9}$ inscientiam : composition? ${ }^{10}$ arbitrābantur: synonym of exīstimō.

Think of English words from factae, plāniōrēs, excipere, flūctuum, tōtae, confectae, onera, and observe how the Latin word helps to make plain the meaning of the English derivative.

\section{EXERCISE LIX}

Grammar: A. 374, $a ; 537,1 ; 569,2$. B. $1 \$_{9}, 1 ; 284,1: 297,2$. G. $355 ; 552 ; 553$, 4. H. $431 ; 570 ; 57$ I, I.

Inflection: ferō; vīs; facile (compare).

Order of words: the words of a phrase, clause, or sentence are arranged from the beginning in the order of their importance in the mind of the writer.

WHY THE ROMAN SHIPS ARE INFERIOR TO THOSE OF TIE VENETI

Cum hìs ${ }^{1}$ nāvibus nostrae classi $\bar{i}^{2}$ eius modì congressus ${ }^{3}$ erat ut ūnā celeritāte et pulsū ${ }^{4}$ rēmōrum praestāret, reliqua prō locī nātūrā, prō vì tempestātum, illìs ${ }^{5}$ essent aptiōra et accommodātiōra. Neque enim iis ${ }^{6}$ nostrae rōstrō nocēre poterant, tanta in īis erat fīrmitūdō, ${ }^{7}$ neque propter altitūdinem facile tēlum adigēbātur, ${ }^{8}$ et eādem dē causā minus commodē cōpulīs continēbantur. Accēdēbat ${ }^{9}$ ut, cum saevīre ventus coepisset et sē ventō dedissent, et tempestātem ferrent facilius et in vadīs cōnsisterent tūtius et ab aestū relictae nihil saxa et cautìs timērent; quārum rērum omnium nostrīs nāvibus cāsus erat extimēscendus. ${ }^{10}$ - I)E Bello Gallico, III, 13

\section{VOCABULARY}

$$
\text { cōpula, ae, f.. grappling hook tūtē, safely' }
$$

\section{NOTES}

1 his: i.e. of the Veneti. 2 classĩ : shows the possessor. ${ }^{3}$ congressus: noun from congredior. ${ }^{4}$ pulsū: noun from pellō. ${ }^{5}$ illis : i.e. hīs nāvibus. ${ }^{6}$ iìs: with nocēre. ${ }^{7}$ fïrmitūdō: fïrmus + tūdō. 


\section{DE BELLO GALLICO, III}

8 adigēbātur: was hurled to (the'm). ${ }^{9}$ accēdēbat: anothcr fact wias. 10 extimēscendus: synonym of timeō.

Observe the phrases in the passage, noting how their position in the sentence expresses their relative importance in the mind of Cæsar.

\section{EXERCISE LX}

Grammar: A. 372: $573 ; 57$ 4. B. $256.3: 300$, I. G. $208,2:+52,2$; 467. H. 302, 6: 649, II.

Inflection: sümō: turris.

Order of words: the antecedent of a relative is usually placed immediately before it.

CASAR SENDS FOR THE ROMAN SHIPS AND THE TIO FLEETS ENGAGE IN BATTLE

Complūribus expugnātìs oppidis Caesar, ubi intellēxit frūstrā tantum labōrem sūmì neque hostium fugam captīs oppidìs reprimīi ${ }^{1}$ neque iīs ${ }^{2}$ nocērî posse, statuit exspectandam classem. Quae ubi convēnit ac prīmum ab hostibus vīsa est, circiter ducentae et trīgintā nāiès eōrum parātissimae atque omnī genere armōrum ōrnātissimae profectae ex portū nostrīs adversae cōnstitērunt; neque satis Brūtō, quī classī praeerat, vel tribūnìs mīlitum centuriōnibusque, quibus singulae nāvēs erant attribūtae, cōnstābat ${ }^{3}$ quid agerent aut quam ratiōnem pugnae īnsisterent. Rōstrō enim nocērī nōn posse cogñōverant; turribus autem excitātīs, tamen hās altitūdō puppium ex barbarīs nāvibus superābat, ut neque ex inferiōre locō satis commodē tēla adiḡi possent et missa ${ }^{4} \bar{a}$ Gallis gravius acciderent. ${ }^{j}$

$$
\text { I)E Bello Gallico, III, i } 4
$$

\section{VOCABULARY}

ōrnō, 1, equip

attribūo, 3, ūi, ūtus, assign

excitō, I, build up

\section{NOTES}

${ }^{1}$ reprimī: re + premō. 2 iīs: dative with nocērī used impersonally. ${ }^{3}$ cōnstābat: impersonal. ${ }^{4}$ missa: understand ea referring to tèla. 5 acciderent: fell. 


\section{EXERCISE LXI}

Grammar: A. $3 S_{2,1} ; 542 ; 549$. B. 191, 1; 288, 3 : 286, 2. G. 356 ; $58+; 586$. H. 433,$3 ; 601,4: 598$.

Inflection: gerō: magis (compare).

Order of words: the beginning of the sentence is a place of emphasis.

HOW THE ROMANS HAVE THE ADVANTAGE IN THE FIGHT

Ū na erat magnō ùsuī rēs praeparāta ${ }^{1}$ à nostrīs, falcēs praeacūtae insertae $^{2}$ affīxaeque $^{3}$ longuriis, nōn absimilit ${ }^{4}$ fōrmā $^{5}$ mūrālium ${ }^{6}$ falcium. Hīs cum fūnēs quī antemnās ad mālōs dēstinābant comprehēnsì adductīque erant, nāvigiō rēmîs incitātō praerumpēbantur. Quibus abscīsīs antemnae necessāriō concidēbant, ut, cum omnis Gallicīs ${ }^{\overline{7}}$ nāvibus spès in vēlīs armāmentìsque cōnsisteret, hìs ēreptīs omnis ūsus nāvium ūnō tempore ēriperētur. Reliquum erat certāmen positum $^{\varsigma}$ in virtūte, quā nostrī mìlitēs facile superābant, atque eō magis quod in cōnspectū Caesaris atque omnis exercitūs rēs gerēbātur, ut nūllum paulō fortius factum ${ }^{9}$ latēre posset ${ }^{10}$; omnēs enim collēs ac loca superiōra unde erat propinquus dēspectus ${ }^{11}$ in mare ab exereitū tenēbantur. - I )E Bello Gallico, III, I 4

\section{VOCABULARY}

falx, failcis, f., hook praeacūtus, a, um, sharpened to a

point

longurius, longu'rī, m., long pole antemna, ae, f., scil-yard mālus, ì, m., mast dèstinō, 1, bind fast to comprehendō, 3, hendi, hēnsus, seize nāvigium, nāvi'gī, n., boat praerumpō, 3 . rūpī, ruptus, break off abscīdō, 3, cìdì, cìsus, cut away concidō, 3. cidī, —, fall armämentum, i, n., tackle èripiō, 3, uī, reptus, tear acuay

\section{NOTES}

${ }^{1}$ praeparāta : composition? $\quad{ }^{2}$ insertae: participle. English derivative? ${ }^{3}$ affixae: participle. English derivative? 4 absimili: composition? The prefix has the force of a negative. ${ }^{5}$ fōrmā: describes falcēs. 
${ }^{6}$ mūrālium: mūrus + ālis, belonging ${ }_{S}$ to. $\quad{ }^{\top}$ Gallicīs: Gallia + icus, English "-ic." $\quad 8$ erat positum: depended. ${ }^{9}$ factum: participle of faciō, used as a noun. $\quad{ }^{10}$ posset: shows a result of quod ... gerēbātur. $\quad{ }^{11}$ dēspectus : cf. cōnspectū above.

Many English words are derived from words in the passage. Make a list, and observe the relation in meaning between the Latin and the English word.

\section{EXERCISE LXII}

Grammar: A. $5+2$ : 5.9. B. $22 S, 3$; 286, 2; 309. 3. G. 58+; 586 ; 587. H. 60 I, $4: 598$.

Inflection: reperiō; bīnī.

Order of words: numeral adjectives and adjectives of quantity usually precede the word which they limit.

A CALM PREVENTS TIIE FLIGITT OF TIE ENEMY ANI) THE ROMANS ARE VICTORIOLS

Dēiectīs, ut dīximus, antemnīs, cum singulās bīnae ac ternae nāvēs circumsteterant, mīlitēs summā vī trānscendere in hostium nāvīs contendēbant. Quod ${ }^{1}$ postquam barbarī fierī animadvertērunt, expugnātīs complūribus nāvibus, cum eì reì nūllum reperīrētur auxilium, fugā salūtem petere contendērunt. Ac iam conversīs in eam partem nāvibus quō ventus ferēbat, tanta subitō malacia ac tranquillitās $^{2}$ exstitit ut sē ex locō movēre nōn possent. Quae quidem rēs ad negōtium cōnficiendum maximē fuit opportūna ; nam singulās nostrī cōnsectātī expugnāvērunt, ut perpaucae ${ }^{3}$ ex omnī numerō noctis interventū ${ }^{4}$ ad terram pervenirent, cum ab hōrā ferē quārtā ūsque ad sōlis occāsum pugnārētur.

De Bello Gallico, III, i 5

\section{VOCABULARY}

antemna, ae, f., sail-yard trānscendō, 3, scendī, scēnsus, climb ozer malacia, ae, f., calm exsistōo, 3, stitī, — , arise ùsque, er'en 


\section{NOTES}

1 quod: a relative. the prefix is intensive.

2 tranquillitās: English derivative? 4 interventū: inter + veniō.

${ }^{3}$ perpaucae:

By this battle the war with the Veneti is ended. C'esar punishes the survivors severely that in the future the rights of ambassadors may be upheld.

\section{EXERCISE LXIII}

Grammar: A. 374, a; 500, 2; 504. B. 189.1 : 337, S. b, I ; 338, I, $a$. G. $355 ; 251,1: 428$. H. $431 ; 621 ; 626$.

Inflection: nōlō; vōx; duo.

Order of words: the antecedent of a relative is usually placed immediately before it.

SABINUS ANONG TIIE VENELLI. IIE REFUSES TO FIGIT

Dum haec in Venetīs ${ }^{1}$ geruntur, ${ }^{2}$ Quintus Titūrius Sabīnus cum iis cōpiīs quās ā Caesare accēperat in fīnīs Venellōrum pervēnit. Hìs $^{3}$ praeerat Viridovìx ac summam imperī tenēbat eārum omnium cīvitātum quae dēfēcerant, ${ }^{4}$ ex quibus exercitum magnāsque cōpiās coēgerat; atque hīs paucīs diēbus Aulercì Eburovīcēs Lexoviīque, senātū suō interfectō quod auctōrēs ${ }^{5}$ bellī esse nơlēbant, ${ }^{6}$ portās ${ }^{7}$ clausērunt sēque cum Viriclovìce coniūnxērunt; magnaque praetereā multitūdō undique ex Galliā perditōrum hominum latrōnumque convēnerat, et quōs ${ }^{8}$ spēs praedandī studiumque bellandī ab agrī cultūrā et cotĩdiānō labōre sēvocābat. ${ }^{9}$ Sabīnus idōneō ${ }^{10}$ omnibus rēbus ${ }^{11}$ locō castrīs sēsē tenēbat, cum Viridovìx contrā eum duōrum mīlium spatiō cōnsēdisset cotìdiēque prōductīs cōpiìs pugnandī potestātem faceret, ut iam nōn sōlum hostibus in contemptiōnem ${ }^{12}$ Sabinus veniret sed etiam nostrōrum militum vōcibus nōn nihil ${ }^{13}$ carperētur ; tantamque opiniōnem timōris praebuit ut iam ad vāllum castrōrum hostēs accēdere audērent. Id eā dē causā faciēbat, quod ${ }^{14}$ cum tantā multitūdine hostium, praesertim eō absente quī summam imperī tenēret, nisi aequō locō aut opportūnitāte aliquā datā, lēgātō dìmicandum ${ }^{15}$ nōn exīstimābat. — 1)E Bello Gallico, III, I 7 


\section{VOCABULARY}

claudō, 3, sì, sus, close perditus, a, um, desperate latrō, ōnis, m., robber cultūra, ae, f., cultiziation sēvocō, I, call away carpō, 3. carpsī, carptus, riticize

\section{NOTES}

${ }^{1}$ Venetis: a seacoast tribe in Gaul. " geruntur: dum meaning while is followed by the present tense. $\quad{ }^{3}$ his: for the case, consider praeerat. 4 dēfēcerant: had rềlte'l. " auctōrēs: augeō + tor. English "author." ${ }^{6}$ nōlēbant: states Cæesar's reason for interfectō, hence indicative. $\quad{ }^{7}$ portās : English derivative? "quōs: understand ī as antecedent. "sēvocābat: sē + vocō. Vocō $=$ appellō. $\quad{ }^{10}$ idōneō $:$ fit. ${ }^{11}$ rēbus: limits idōneō, answering the question " in what respect." 12 contemptiōnem: English derivative? 13 nōn nihil: sommazihat. ${ }^{1+}$ quod: causal. 15 dimicandum: synonym of pugnō.

\section{EXERCISE LXIV}

Grammar: A. $3^{67}: 531.2: 573: 57+$ B. $1 \varsigma_{7}$, II, a: 282, 2: $300,1$. G. $346: 630 ; 452,2: 467$. H. 426, I ; 590:649, II.

Inflection: volō; homō: libenter (compare).

Order of words: a genitive, unless emphatic, follows the noun which it limits.

THE TRICK OF SABINLS TO GET THE ENEMIY TO ATTACK THE CAMP

Hăc ${ }^{1}$ cōnfīrmātā opiniōne timōris idōneum quendam hominem et callidum dēlēgit, Gallum, ex ī̄s quōs auxilì causā² sêcum ${ }^{3}$ habēbat. Huic ${ }^{4}$ magniss praemiīs pollicitātiōnibusque ${ }^{j}$ persuādet utī ad hostīs trānseat, et quid fierī velit êdocet. ${ }^{6}$ Quī ubi prō ${ }^{\overline{7}}$ perfugā ad eōs vēnit, timōrem Rōmānōrum prōpōnit, quibus angustiīs ipse Caesar ā Venetīs premātur ${ }^{8}$ docet, neque longius abesse ${ }^{9}$ quīn proximā nocte Sabīnus clam ex castrīs exercitum ēdūcat et ad Caesarem auxilī ferendì causā proficīscātur. Quod ${ }^{10}$ ubi audìtum est, conclāmant ${ }^{11}$ omnēs occāsiōnem negōtị ${ }^{12}$ bene gerendī āmittendam nōn esse; ad castra îrī oportēre. Multae rēs ad hoc cōnsilium 
Gallōs hortābantur, — superiōrum diērum Sabīnī cunctātiō, perfugae cōnfīrmātiō, ${ }^{13}$ inopia cibāriōrum, cui reì parum dỉligenter ab ī̄s erat prōvīsum, spēs Venetici bellī, et quod ${ }^{14}$ ferē libenter hominēs id quod volunt crēdunt. His rēbus adductì nōn prius ${ }^{15}$ Viridovìcem reliquōsque ducēs ex conciliō dīmittunt quam ab iīs sit concessum arma utì capiant et ad castra contendant. Quā rē concessā, laetīi ${ }^{16}$ ut explōrātā victōriā, sarmentīs virgultīsque collēctīs, quibus fossās Rōmānōrum compleant, ad castra pergunt.

$$
\text { Je: Bello Gallico, III, is }
$$

\section{VOCABULARY}

perfuga, ae, m., deserter

cunctātiō, ōnis, f., hesitation

cibāria, ōrum, n.. procisisions

libenter, willingly

crēđō, 3, didī, ditus, believ'e laetus, a, um, glad

sarmentum, $\overline{1}, \mathrm{n}$. , brushwood virgultum, i, n., bush colligō, 3 , lēgì, lēctus, gather

\section{NOTES}

${ }^{1}$ hāc: referring to the account in the preceding chapter. ${ }^{2}$ causā: for the sake of. ${ }^{3}$ sēcum: i.e. Sabinus. ${ }^{4}$ huic: for the case, consider persuãdet. $\quad{ }^{5}$ pollicitātiōnibus : pollicitor + tiōo $\quad$ Pollicitor $=$ polliceor. ${ }^{6}$ èdocet: synonym of docēo. $\quad{ }^{7}$ prō: in the suise of. ${ }^{8}$ premātur: is harassed. ${ }^{9}$ abesse: depends on docet. ${ }^{10}$ quod: the antecedent is the statement of the Gaul. 11 conclāmant: compare English "exclamation." 12 negōtī: synonym of rēs. ${ }^{13}$ cōnfïrmātiō: cōnfïrmō + tiō. This and the other nouns in the same case are appositives of rēs. $\quad{ }^{1+}$ quod: conjunction. ${ }^{15}$ prius: take with quam below. ${ }^{16}$ laeti : translate as if an adverb.

Think of English words from dēlēgit, prōpōnit, proximā, hortābantur, superiōrum, prōvisum, crēdunt, compleant, and observe how the meaning of the Latin word helps to make plain the meaning of the English.

\section{EXERCISE LXV}

Grammar: A. 506; 568. B. 338,3 ; 339, 2; 297 , I. G. 432, R.; 553,3 . H. 628; 571,1 .

Inflection: fīō; certior; noster.

Order of words: in a phrase the emphatic word is usually placed first. 


\section{SABINUS ATTACKS THE ENEMY WHLE THEY ARE AT \\ A DISADVANTAGE AND DEFEATS THEM}

Locus erat castrōrum èditus et paulātim ab ìmō acclivis circiter passūs mille. Hūc magnō cursū $\overline{1}^{1}$ contendērunt, ut quam minimum² spatī ad sē colligendōs armandōsque Rōmānīs darētur, exanimātīque ${ }^{3}$ pervēnērunt. Sabīnus suōs hortātus cupientibus ${ }^{+}$signum dat. Impedīīs hostibus propter ea quae ferēbant onera, subitō duābus portīs ēruptiōnem fierī iubet. Factum est" opportūnitāte locī, hostium inscientiā ac dēfatīgātiōne, virtūte militum et superiōrum pugnārum exercitātiōne, ut nē prīmum quidem nostrōrum impetum ferrent ac statim terga verterent. ${ }^{6}$ Quōs integrīs vïribus mìlitēs nostrī cōnsecūtĩ magnum numerum eōrum occīdērunt ; reliquōs equitēs ${ }^{\top}$ cōnsectātī paucōs, quī ex fugā ēvāserant, relīquērunt. Sìc ūnō tempore et dē nāvālīi pugnā Sabinus et dē Sabīnī victōriā Caesar est certior factus, ${ }^{9}$ cīvitātēsque omnēs sē statim 'Titūriō dēdidērunt. ${ }^{10}$ Nam ut ${ }^{11}$ ad bella suscipienda Gallōrum alacer ac prōmptus est animus, sīc mollis ac minimē resistēns ad calamitātēs ferendās mēns ${ }^{12}$ eōrum est. - De Bello Gallico, III, I9

\section{VOCABULARY}

acclivis, e, sloping up

colligō, 3 , lēgī, lēctus, collect

inscientia, ae, f.. ignorance dēfatīgātiō, ōnis, f., exhanstion integer, gra, grum, fiesh

\section{NOTES}

1 cursū: answers the question "how" about contendērunt. 2 quam minimum: the least possible. ${ }^{3}$ exanimāti: out of brèth. ${ }^{4}$ cupientibus : used substantively; translate by a demonstrative pronoun and a relative clause. $\quad{ }^{5}$ factum est: it haffened. $\quad{ }^{6}$ verterent: think of the compounds āvertō and convertō. $\quad{ }^{\bar{\imath}}$ equitēs: nominative. ${ }^{8}$ nāvālī: nāvis $+\bar{a} l i s$, pertaining to. $\quad{ }^{9}$ est factus: has two subjects. $\quad{ }^{10}$ dēdidērunt: from the same stem is derived the noun dēditiō. 11 ut: for the meaning, consider the mode of est. 12 mēns : synonym of animus.

The tribes of Aquitania, in southwestern Gaul, revolt against Crassus, sent among them by Casar, and choose as leaders men who have had experience in Spain and know the Roman methods of warfare. After vigorous fighting the enemy's camp is taken and the revolt crushed. 


\section{EXERCISE IXXI}

Grammar: A. $496: 540.1$. B. $337,2, a, f ; 286$, I. G. $66_{4} ; 665$; 666: 5 +o. H. 63\$. I : $588, \mathrm{I}$.

Inflection: cōnficiō : opus.

Order of words: the preposition regularly precedes the word which it governs.

TIIE MORINI AND THE MENAPII FROM THEIR FORESTS ANI) SWAMPS ANXOY TIIE ROMANS

Eōdem ferē tempore ${ }^{1}$ Caesar, etsī prope exācta iam aestās erat, tamen quod omnì Galliā pācātā Morinì Menapīique supererant quī in armīs essent neque ad eum umquam lēgātōs dē pāce mīsissent, arbitrātus $^{2}$ id bellum celeriter cōnficī posse eō exercitum dūxit ; quī longe $\bar{e}^{3}$ aliā ratiōne ac ${ }^{4}$ reliquī Gallì bellum gerere coepērunt. Nam quod intellegēebant maximās nātiōnēs quae proeliō contendissent pulsās superātāsque esse, continentīsque ${ }^{\tilde{y}}$ silvās ac palūdēs habēbant, eō sē suaque omnia contulērunt. Ad quārum initium silvārum cum Caesar pervēnisset castraque mūnìre īnstituisset, neque hostis interim vìsus esset, dispersīs in opere nostrīs subitō ex omnibus partibus silvae èvolāvērunt et in nostrōs impetum fēcērunt. Nostrī celeriter arma cēpērunt eōsque in silvās reppulērunt, et, complūribus interfectīs, longius impeditiōribus locīs secūtī paucōs ex suis dēperdidērunt. - I) E Bello Gallico, III, 28

\section{VOCABULARY}

$$
\begin{aligned}
& \text { exigō, 3, ēgī, āctus, finish } \\
& \text { ēvolō, 1, fly out } \\
& \text { umquam, exer } \\
& \text { dēperdō, 3, didī, ditus, lose }
\end{aligned}
$$

\section{NOTES}

1 tempore: i.e. that of the events referred to in the last note of Exercise LXY. 2 arbitrātus: synonym of exisstimō. $\quad{ }^{3}$ longē: with aliā. ${ }^{4}$ ac: than. ${ }^{5}$ continentis: unbroken.

Select several short phrases from the passage and determine the emphatic word in each phrase. 


\section{EXERCISE LXVII}

Grammar: A. $3+5, a: 412: 546$. B. $203: 220,1 ; 288$, I. B. G. 365 ; 399; 585 . H. 440, 3; 473, 3; 600, II, I.

Inflection: diēs; uterque; quis.

Order of words: the words in a phrase, clause, or sentence are arranged in the order of the development of the thought in the writer's mind.

CASAR, HAVING CUT DOWN TIE FORESTS, IS IDEFEATED BY CONTINUAL RAINSTORMS

Reliquīs deinceps diēbus Caesar silvās caedere instituit, et, nē quis ${ }^{1}$ inermibus imprūdentibusque mîlitibus ${ }^{2}$ ab latere impetus fierī posset, omnem eam māteriam quae erat caesa conversam ad hostem collocābat et prō vāllō ad utrumque latus exstruēbat. Incrēdibilī celeritāte $^{3}$ magnō spatiō paucīs diēbus cōnfectō, cum iam pecus atque extrēma ${ }^{4}$ impedīmenta à nostrīs tenērentur, ipsī dēnsiōrēs silvās peterent, eius modī sunt tempestātēs cônsecūtae utī opus necessāriō intermitterētur et continuātiōne ${ }^{50}$ imbrium diūtius sub pellibus ${ }^{6}$ mìlitēs continērī nōn possent. Itaque vāstātīs omnibus eōrum agrīis, vīcīs aedificiīsque incēnsīs, Caesar exercitum ${ }^{7}$ redūxit et in Aulercīs Lexoviīsque, reliquīs item cīvitātibus quae proximēe bellum fēcerant, in hībernīs collocāvit.

\section{De Bello Gallico, III, 29}

\section{VOCABULARY}

deinceps, in succession

imber, bris, m., rainstorm imprūdēns, imprūdentis, off one's guard

\section{NOTES}

${ }^{1}$ quis: with impetus. ${ }^{2}$ militibus: dative. ${ }^{3}$ celeritāte: answers the question "how" about cōnfectō. ${ }^{4}$ extrēma: the rear of. ${ }^{5}$ continuàtiōne: states a reason for continērī nōn possent. $\quad{ }^{6}$ pellibus: the material used as a covering for the tents. ${ }^{7}$ exercitum: with collocāvit as well as with redūxit. 


\section{EXERCISE LXVIII}

Grammar: A. $406: 415: 504$. B. 217, I ; 224, I; 338, I, a. G. $39^{8}$; $400 ; 428$. H. $471 ; 473,2 ; 626$.

Inflection: maneō; domus; ille.

Order of words: in a phrase or sentence the emphatic word is likely to be placed first.

A DESCRIPTION OF THE SUEBI, WHO HAVE FORCED SOME OF THE OTHER GERMAN TRIBES TO CROSS THE RHINE

Eā quae secūta est hieme, quī fuit annus Gnaeō Pompēiō, Mārcō Crassō cōnsulibus, Usipetēs Germānī et item Tencterī magnā cum multitūdine hominum flūmen Rhēnum trānsiērunt nōn longē à marī, quō Rhēnus ìnfluit. ${ }^{1}$ Causa trānseundī fuit quod² ab Suēbīs complūrīs annōs exagitātī bellō premēbantur et agrī cultūrāā prohibēbantur. Suēbōrum gēns est longē maxima et bellicōsissima Germānōrum omnium. Hì centum pāgōs habēre dìcuntur, ex quibus quotannīs singula milia armātōrum bellandì causā ex fīnibus èdūcunt. Reliquī, quī domì mānsērunt, sē atque illōs alunt; hì ${ }^{4}$ rūrsus invicem anno $\overline{5}^{5}$ post in armìs sunt, illī domĩ remanent. Sìc neque agrī cultūra nec ratiō atque ūsus bellī intermittitur. Sed prīvātī ac sēparāti ${ }^{6}$ agrī $^{7}$ apud eōs nihil est, neque longius annō remanēre ūnō in locō colendī causā licet. Neque multum frūmentō, sed maximam partem lacte atque pecore vīvunt, multumque sunt in vēnātiōnibus; quae rēs et cibī genere et cotīdiānā exercitātiōne et libertāte vìtae, quod à puerìs nūllō officiō aut disciplinnā ${ }^{8}$ assuêfactī nihil omnīnō contrā voluntātem faciunt, et vīrīs ${ }^{9}$ alit et immānī corporum magnitūdine hominēs efficit. Atque in eam sē cōnsuētūdinem addūxērunt ut locīs ${ }^{10}$ frìgidissimīs ${ }^{11}$ neque vestītūs praeter pellīs habērent quicquam, quārum propter exiguitātem magna est corporis pars aperta, et lavărentur in flūminibus.

$$
\text { De Bello Gallico, IV, I }
$$




\section{VOCABULARY}

exagitō, I, harass

gēns, gentis, f., tribe

bellicōsus, a, um, warlike

quotannis, every year

alō, 3, uī, tus, support

invicem, in tum

colō, 3, uī, cultus, till, cultizate

vìvō, 3 , vìxī, vīctum, lì'e vēnātiō, ōnis, f., hunting

vïta, ae, f., life (vitality)

assuēfaciō, 3, fēcī, factus, train

immānis, e, hưge

vestîtus, ùs, m., clothing

exiguitās, ātis, f., siantincss

apertus, a, um, uncovered

lavō, I, lāvì, lautus, bathe (lar

\section{NOTES}

1 influit: composition? $\quad{ }^{2}$ quod: conjunction. ${ }^{3}$ cultūrā: English derivative? $\quad{ }^{4}$ hī: i.e. reliquī. ${ }^{5}$ annō: expresses degree of difference with post. ${ }^{6}$ sēparātĩ: English derivative? ${ }^{7}$ agrī: take with nihil. ${ }^{8}$ disciplīnā: English derivative? ${ }^{9}$ vīrīs: from vīs. ${ }^{10}$ locīs: ablative absolute expressing concession. 11 frïgidissimis: English derivative?

\section{EXERCISE LXIX}

Grammar: A. $345 ; 373 ; 410 ; 416$. B. 203,$5 ;$ I90; 2I 8, I ; 225. G. $365 ; 366 ; 349 ; 407 ; 404$. H. 440,$3 ; 4+7 ; 430 ; 477, \mathrm{I} ; 478$, I.

Inflection: dēsiliō; vēstīgium.

Order of words: the limiting word is likely to precede the word which it limits.

THE SCORN OF THE SUEBI FOR TIIE CUSTOMS AND PRODUCTS OF FOREIGNERS

Mercātōribus ${ }^{1}$ est aditus magis e⿳亠丷, ut quae ${ }^{2}$ bellō cēperint quibus vēndant habeant, quam quō ${ }^{3}$ ūllam rem ad sē importārī dēsīderent. ${ }^{4}$ Quin etiam iümentīs, quibus maximē Gallì dēlectantur quaeque impēnsō parant pretiō, Germānī importātīs ${ }^{5}$ nōn ūtuntur, sed quae sunt apud eōs nāta, parva atque dēfōrmia, haec cotīdiānā exercitātiōne summī ut sint labōris efficiunt. Equestribus proelī̄s saepe ex equīs dēsiliunt ac pedibus proeliantur, ${ }^{6}$ equōsque eōdem remanēre vēstīgiō assuēfēcērunt, ad quōs sē celeriter, cum ūsus cst, recipiunt; 
neque eōrum mōribus turpius quicquam aut inertius habētur ${ }^{7}$ quam ephippiīs ùtī. Itaque ad quemvīs numerum ephippiātōrum ${ }^{8}$ equitum quamvĩs paucì adīre audent. V'inum omnīnō ad sē importārī nōn patiuntur, quod eā rē ad labōrem ferendum remollēscere hominēs atque effēminārī arbitrantur. ${ }^{9}$ - I)E Bello Gallico, IV, 2

\section{VOCABULARY}

iūmentum, $\overline{1}, \mathrm{n}$.. beast of burden iners, inertis, unskillful

dēlectō, 1, delight

impēnsus, a, um, ércessiz'e. high

dēfōrmis, e, misshapen

ephippium, ephippi, n., saddle cloth vinum, $\bar{i}, \mathrm{n}$. , wine

remollēscō, 3, - - L lose strength assuēfaciō, 3. fēcī, factus, train effēminō, 1, make womanish turpis, e, disgraceful

\section{NOTES}

1 mercātōribus: dative showing the possessor. ${ }^{2}$ quae: understand ea, object of vēndant, as antecedent. ${ }^{3}$ quō: because. ${ }^{4}$ dēsiderent: synonym of cupiō. $\quad{ }^{5}$ importātis: with iümentis. $\quad{ }^{6}$ proeliantur: from proelium. ${ }^{7}$ habētur: is considered. ${ }^{8}$ ephippiātōrum: ephippium + ātus, frovided with. ${ }^{9}$ arbitrantur: synonym of existimō.

The Usipetes and the Tencteri, German tribes, forced by the Suebi, cross the Rhine and invade the territory of the Menapii in the extreme northern part of Gaul. They conquer these and seize their towns and property.

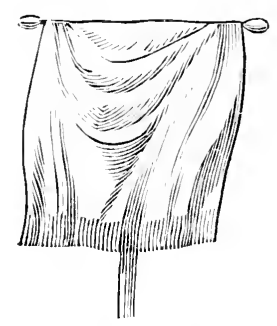

VEXILLUM 


\section{EXERCISE LXX}

Grammar: A. 343, b: 354. b: 573. B. 198, 3: 209, 1: 300, 1, N. G. $366 ; 377 ; 452$, 2. H. $4+7: 457 ; 649.11$.

Inflection: paenitet; certior.

Order of words: demonstrative, relative, and interrogative pronouns usually precede the words which they modify.

\section{CESAR FEARS THE FICKLENESS AND CREDULITY OF TIIE GALLS}

Hìs dē rēbus ${ }^{1}$ Caesar certior factus et infīrmitātem² Gallōrum veritus, quod sunt in cōnsilī̄s capiendīs mōbilēs et novīs plērumque rēbus student, nihil hīs committendum ${ }^{3}$ exīstimāvit. Est enim hoc Gallicae cōnsuētūidinis, ${ }^{4}$ utī et viātōrēs ${ }^{5}$ etiam invìtōs cōnsistere cōgant, et quid quisque eōrum dē quāque rē audierit aut cognōverit quaerant, et mercātōrēs in oppidīs vulgus circumsistat, ${ }^{6}$ quibusque ex regiōnibus veniant quāsque ibi rēs cognōverint prōnūntiāre cōgat. Hìs rēbus atque auditiōnibus ${ }^{\overline{7}}$ permōtī dē summis saepe rēbus cōnsilia ineunt, quōrum ê̄s in vēstīgiō paenitēre necesse est, cum incertīs rūmōribus serviant, et plērīque ad voluntātem eōrum ficta respondeant. - De Bello Gallico, IV, 5

\section{VOCABULARY}

mōbilis, e, changeable

serviō, + , ivìi, ìtum, be a slar'e, sc'r'c'

necesse (indeclinable), necessary

\section{NOTES}

${ }^{1}$ his rèbus: i.e. the advance of the L'sipetes and the Tencteri. $\quad 2$ infïrmitātem: in + fïrmus + tās. ${ }^{3}$ committendum: understand esse. ${ }^{4}$ cōnsuētūdinis: predicate genitive. ${ }^{5}$ viātōrēs: via + tor. ${ }^{6}$ circumsistat: for the mood, compare cōgant. $\quad{ }^{\top}$ auditiōnibus: audiō + tiō; reports.

Cæsar demands that the Germans leave Gaul, but they say that they cannot endure the Suebi. Ile then proposes that they settle among the Ubii, just on the other side of the Rhine. The Germans ask that Casar remain where he is while this proposal is being considered, but Casar thinks this is a ruse to gain time. 


\section{EXERCISE LXXI}

Grammar: A. 393. a: 406. B. I77, I, 3; 217 , I. G. 340, b, R. I ; 39. H. $+10,1 ;+71$.

Inflection: orior: avis.

Order of words: a dependent genitive, unless emphatic, usually follows the word which it limits.

THE COLRSE OF THE MEUSE AND THE RHINE

Mosa prōfluit ${ }^{1}$ ex monte Vosegō, quī est in fïnibus Lingonum, et parte quādam ex Rhēnô receptā, quae appellātur Vacalus, ${ }^{2}$ innsulam efficit Batāoōrum neque longius inde ${ }^{3}$ mìlibus passuum octōgintā in Ōceanum influit. ${ }^{+}$Rhēnus autem oritur ex Lepontī̄s, quī Alpīs incolunt, et longō spatiō per fīnīs Nantuātium, Helvētiōrum, Sēquanōrum, Mediomatricum, Tribocōrum, Trēverōrum citātus ${ }^{\tilde{s}}$ fertur, et ubi (َ)ceanō appropinquāvit ${ }^{6}$ in plūrīs diffluit ${ }^{\top}$ partīs multīs ingentibusque insulīs effectīs, quārum pars magna ā ferīs barbarīsque nātiōnibus incolitur (ex quibus sunt quī piscibus atque ôvīs avium vīvere exīstimantur), multīsque capitibus in Ōceanum influit.

$$
\text { De Bello Gallico, IV, io }
$$

\section{VOCABULARY}

citātus, a, um, süilift ingēns, ingentis, lluge

piscis, is, m., fish ōvum, i, n.. çgr

vīvō, 3, vixīi, vīctum, liz'e

NOTES

${ }^{1}$ prōfluit: composition? $\quad{ }^{2}$ Vacalus: predicate nominative. ${ }^{3}$ inde: i.e. ab insulā. $\quad{ }^{4}$ influit: composition? $\quad{ }^{5}$ citātus: give it the force of an adverb. ${ }^{6}$ appropinquāvit: the root is found in the adverb prope. 7 diffluit: composition? 


\section{EXERCISE LXXII}

Grammar: A. 504, $a ; 506 ; 563$. B. 338, I, $a, 5 ; 339,2 ; 295$, I. G. $428 ; 432 ; 546$. H. 626; 62S: 565 .

Inflection: revertor; iūs; ipse.

Order of words: commonly temporal clauses precede, and purpose clauses follow, the verb on which they depend.

THE GERMANS ASK C.ESAR NOT TO ADVANCE AND NOT TO FIGHT FOR A FEW DAYS

Caesar cum ab hoste nōn amplius passuum duodecim milibus abesset, ut ${ }^{1}$ erat cōnstitūtum, ad eum lēgātī revertuntur; quī in itinere congressī magnopere nē longius prōgrederētur ${ }^{2}$ órābant. Cum id nōn impetrāssent, petēbant utī ad eōs equitēs quī agmen antecessissent praemitteret cōsque pugnā prohibēret, sibique ut potestātem faceret ${ }^{3}$ in U Ubiōs lẹgātōs mittendī; quōrum ${ }^{4}$ sì principēs ac senātus sibi iūre iūrandō fidem fēcisset, eã condiciōne quae à Caesare ferrētur ${ }^{5}$ sē ùsūrōs ostendēbant; ad hās rēs cōnficiendās sibi trìdū̄ spatium daret. ${ }^{5}$ Haec omnia Caesar eōdem illō pertinēre arbitrābātur, ${ }^{i}$ ut triduī morā interpositā equitēs eōrum quī abessent reverterentur; tamen sēsē nōn longius milibus passuum quattuor aquātiōnis causā prōcessūrum eō diē dỉxit; hūc posterō diē quam ${ }^{8}$ frequentissimī convenirent, ut dē eōrum postulātīs ${ }^{9}$ cognōsceret. Interim ad praefectōs, quī cum omnī equitātū antecesserant, mittit quī nūntiārent nē hostīs proeliō lacesserent, et, sì ipsī lacesserentur, sustinērent quoad ipse cum exercitū propius accessisset.

$$
\text { Je Bello Gallico, IV, i i }
$$

\section{VOCABULARY}

antecēdō, 3, cessīi, cessum, go ahead aquātiō, ōnis, f., getting water frequēns, frequentis, in large numbers

\section{NOTES}

1 ut: as. $\quad{ }^{2}$ prōgrederetur: the root of this word is found in gradus, step. ${ }^{3}$ potestātem faceret: giz'e an ofportunity. ${ }^{4}$ quōrum: the antecedent is Ubiōs. Cæesar's proposal was that the Germans should settle in this tribe's 
territory. ${ }^{5}$ ferrētur: was proposed. ${ }^{6}$ daret: in the words of the Germans this was an imperative. $\quad{ }^{7}$ arbitrābātur: synonym of exīstimō. ${ }^{8}$ quam: possible. $\quad{ }^{9}$ postulātīs: participle of postulō used as a noun.

\section{EXERCISE IXXIII}

Grammar: A. $370: 382: 403$, a. B. 187 , III : 191. 1: 215. G. 347 ; 356: 395. H. $429 ; 433 ; 467: 469,2$.

Inflection: cadō; frāter; timēns.

Order of words: the possessive adjectives, unless emphatic, follow the noun which they modify.

\section{IN A CAVALRY SKIRMISH WITII THE ENENY THE} ROMANS LOSE SEVERAL IIEN

At hostēs, ubi prīmum nostrōs equitēs cōnspexērunt, ${ }^{1}$ quōrum erat quinque mīlium numerus, cum ipsī nōn amplius octingentōs equitēs habērent, quod iī quī frūmentandī causā ierant trāns Mosam nōndum redierant, nihil timentibus nostrīs, quod lēgātī eōrum paulō² ante ā Caesare discesserant atque is diēs indūtīis erat ab hīs petìtus, impetū factō celeriter nostrōs perturbāvērunt; rürsus his resistentibus cōnsuētūdine suā ad pedēs dēsiluērunt, suffossīsque equīs complüribusque nostrīs dēiectīs reliquōs in fugam coniēcērunt, atque ita perterritōs ègērunt ut nōn prius ${ }^{3}$ fugā dēsisterent quam in cōnspectum agminis nostrī vēnissent. In eō proeliō ex equitibus nostrìs interficiuntur quattuor et septuāgintā, in hìs vir fortissimus Pisō Aquītānus, amplissimō genere ${ }^{4}$ nàtus, cuius avus in civitāte suā rēgnum obtinuerat amìcus ā senātū nostrōo appellātus. Hīc cum frātrī interclūsō ab hostibus auxilium ferret, illum ex perīculō èripuit, ipse equō vulnerātō dēiectus quoad potuit fortissimē restitit ; cum circumventus multis vulneribus acceptis cecidisset, atque id frāter, quī iam proeliō excesserat, procul animadvertisset, incitātō equō sē hostibus obtulit" atque interfectus est.

De Bello Gallico, IV, i 2 


\section{VOCABULARY}

octingentī, ae, a, eight hundred

frūmentor, I, forage

indütiae, ärum, f., trace

suffodiō, 3 , fōdī, fossus, stab from belowe avus, $\overline{1}, \mathrm{~m} .$, grandfather

èripiō, 3, uī, reptus, rescue

procul, from a distance

\section{NOTES}

1 cōnspexērunt: compare with dēspiciō and cōnspectus. $\quad{ }^{2}$ paulō: synonym of parvō. $\quad{ }^{3}$ prius: take with quam following. ${ }^{4}$ genere: lineage. 5 obtulit: ob + ferō. English derivative?

The passage contains many words from which English words are derived. Make a list.

Cæsar distrusts the Gauls, and when after the battle their representatives come to him to make excuses, he has them arrested, and at once sets out with the army for their camp. Before they know what is going on, he storms their camp and inflicts on them fearful punishment. Because of the trouble which the Germans keep causing him, Cæsar determines to cross the Rhine and attack them.

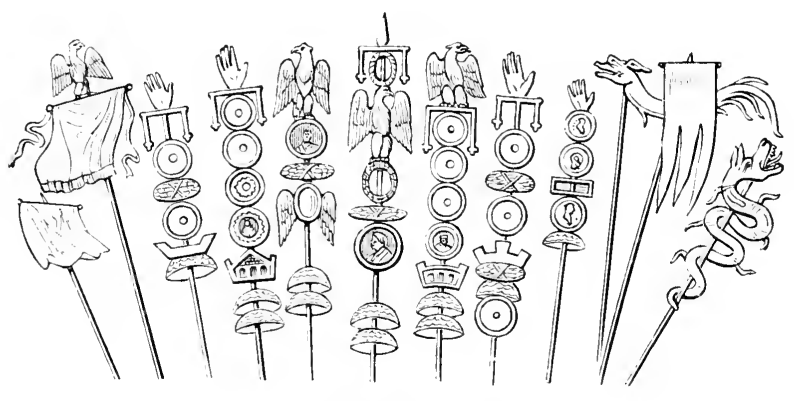

SIGNA MILITARIA 


\section{EXERCISE LXXIV}

Grammar: A. $343, b ; 374, a: 414, a$. B. $198,3: 189,1 ; 223$. G. $366: 355 ; 403$. H. 447 : $+31 ;+79, \mathrm{I}$.

Inflection: dēfīgō: aqua : bīnī.

Order of words: in a phrase or sentence the emphatic word is commonly placed first.

A DESCRIPTION OF THE BRIDGE TIIAT CASAR BUILT ACROSS THE RHINE

Caesar hīs dē causīs quās commemorāvĩ Rhēnum trānsīre dēcrēverat; sed nāvibus trānsīre ${ }^{1}$ neque satis tūtum esse arbitrābātur neque suae neque populi Rōmānī dignitātis ${ }^{2}$ esse $^{3}$ statuēbat.

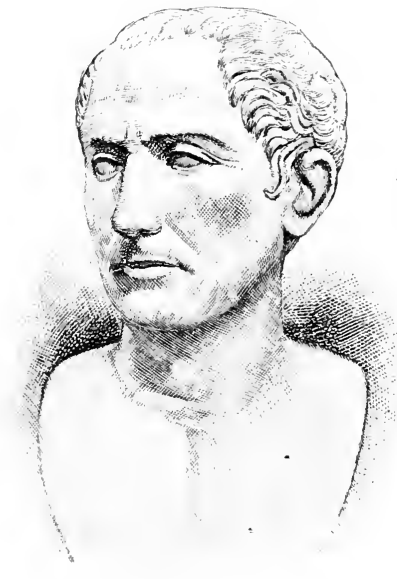

GAIUS 1ULIUS CAESAR

Itaque, etsī summa difficultās faciendī pontis prōpōnēbātur propter lātitūdinem, rapiditātem, ${ }^{4}$ altitūdinemque flūminis, tamen id sibi contendendum aut aliter nōn trādūcendum exercitum exīstimāvit. Ratiōnem pontis hanc īnstituit. 'Tigna bīna sēsquipedālia ${ }^{5}$ paulum ab imo $\overline{ }^{6}$ praeacūta, dìmēnsa ad altitūdinem flūminis, intervāllō pedum duōrum inter sē iungēbat. I Iaec cum māchinātiōnibus immissa in flümen dēfīxerat fistūcīsque adēgerat, nōn sublicae $\operatorname{modō}^{7}$ dērēctē ad perpendiculum, ${ }^{8}$ sed prōnē ac fastīgātē, ut secundum ${ }^{9}$

nātūram flūminis prōcumberent, ì̄s item contrāria duo ad eundem modum iūncta, intervāllō pedum quadrāgēnum ab inferiōre parte ${ }^{10}$ contrā vim atque impetum flūminis conversa statuēbat. Haec utraque insuper bipedālibus ${ }^{11}$ trabibus immissīs, quantum eōrum 


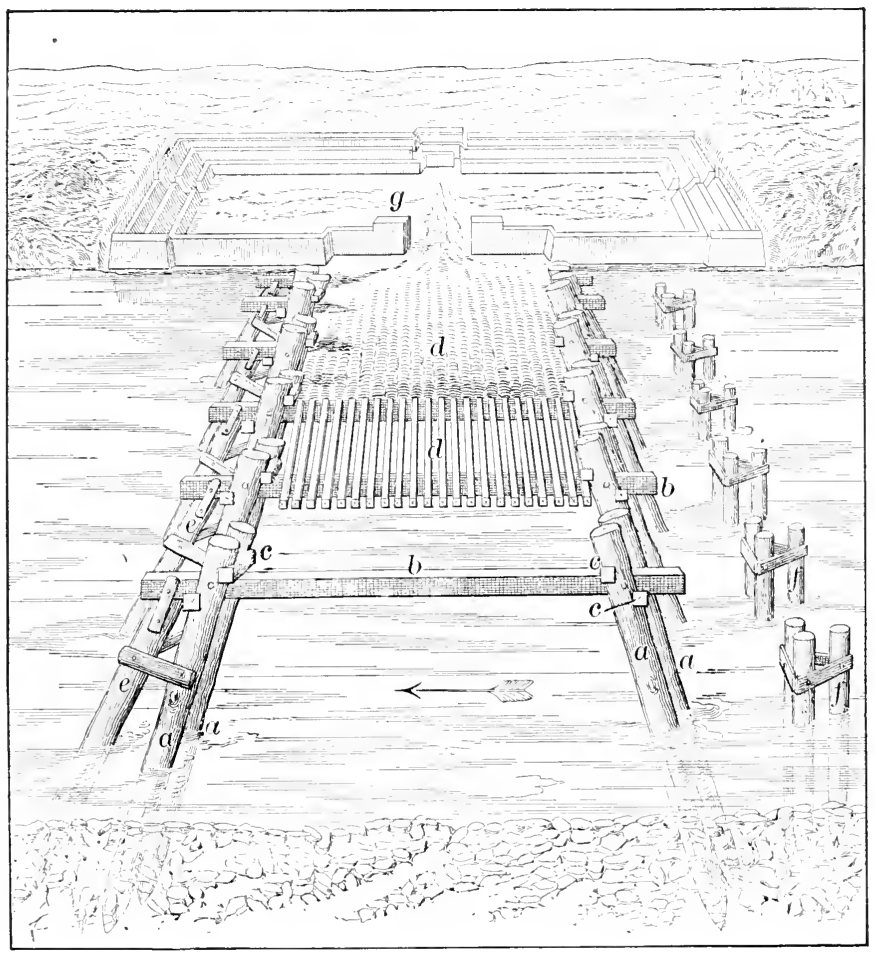

PONS A CAESARE IN RHENO FACTUS

$a c$, tigna bina sesquipedalia ; $b b$, trabes bipedales; $c c$, fibulae;

$d d$, derecta materia longuriis cratibusque constrata;

$c c$, sublicae ad inferiorem partem fluminis pro ariete oblique actae;

$f f$, sublicae supra pontem immissae;

$g$, castellum ad caput pontis positum.

tignōrum iūnctūra ${ }^{12}$ distābat, bīnīs utrimque fỉbulis ab extrēmā parte distinēbantur ${ }^{13}$; quibus disclūsīs atque in contrāriam partem revinctīs ${ }^{14}$ tanta erat operis fïrmitūdo ${ }^{15}$ atque ea ${ }^{16}$ rērum nātūra ut, quō maior vīs aquae sē incitāvisset, hōc artius illigāta tenērentur. Haec dērēctā māteriā iniectā contexēbantur ac longuriis crātibusque 
cōnsternēbantur; ac nihilō sētius sublicae et ad inferiōrem partem flūminis obliqque ${ }^{-1 \overline{ }}$ agēbantur, quae prō ariete subiectae et cum omnì opere coniūnctae vim flūminis exciperent, et aliae item suprā pontem mediocrī spatiō, ut, sī arborum truncī sīve nâvês dèiciendì operis causā essent ā barbarīs immissae, hīs dēfēnsōribus ${ }^{18}$ eārum rērum vīs minuerētur neu pontī nocērent. - De Bello Gallico, IV, I 7

\section{VOCABULARY}

commemorō, I, mention

dēcernō, 3, crēvì, crētus, decide

tūtus, a, um, safe

tignum, i, n., timber

praeacūtus, a, um, sharpened to a point

dimētior, 4, mēnsus, measure off māchinātiō, ōnis, f., mechanical contriziance

fistūca, ae, f., pile driz'er

sublica, ae, f., pile

dērēctus, a, um, straight

fastīgātē, sloping

quadrāgēnī, ae, a, forty each insuper, aboz'e

fïbula, ae, f., brace

disclūđō, 3, clūsī, clūsus, hold apart

artē, closely'

illigō, I, bind

contexō, 3, uī, tus, join together

longurius, longu'rì, m., long pole

crātēs, ium, f., wicker work

cōnsternō, 3 , strāvī, strātus, spread

orer

sētius, less

ariēs, ietis, m., prop

mediocris, e, moderate

truncus, $\bar{i}, \mathrm{~m}$., trunk

\section{NOTES}

1 trānsīe: substantive infinitive, subject of esse. $\quad{ }^{2}$ dignitātis: English derivative? This is a genitive of possession. ${ }^{3}$ esse: belong. ${ }^{4}$ rapiditātem: English derivative? 5 sēsquipedālia: sēsqui, one half more, + pēs + ālis, pertaining to. ${ }^{6} \bar{i} \mathrm{~m} \overline{0}:$ end. ${ }^{7}$ modō: after the manner. ${ }^{8}$ perpendiculum: English derivative? ${ }^{9}$ secundum: accorling to. ${ }^{10} \mathrm{ab}$ inferiōre parte: belowi the bridge. $\quad{ }^{11}$ bipedālibus: bi, taio. Compare sēsquipedālibus. 12 iūnctūra: iungō + tūra. 13 distinēbantur: dis + teneō. ${ }^{14}$ revinctis: fastened back. ${ }^{15}$ firmitūdō: composition? 16 ea: such. 17 oblīquē: English derivative? 18 dēfēnsōribus: dēfendō + tor.

Cæsar leads his army across and devastates the territory. Ile promises the Ubii his help if the Suebi trouble them. IIe learns that the Suebi have retreated. So having accomplished his purpose, he returns to Gaul and destroys the bridge. He then determines to visit Britain because from there help is sent regularly to the enemies of the Romans in Gaul. 


\section{EXERCISE LXXV}

Grammar: A. $49^{6} ; 506$. B. $337,2 . a, f ; 338,3$. G. $665 ; 666$; 432 , R. H. $63 \mathrm{~S}, \mathrm{I} ; 62 \mathrm{~S}$.

Inflection: nāvigō; portus; plānus.

Order of words: the first word in a sentence often refers to something mentioned in the preceding sentence. For this reason a sentence often begins with a relative or demonstrative pronoun.

CESAR SAILS TO INVAIE BRITAIN ANI SEEKS A PLACE TO DISEMBARK

Hìs cōnstitūtīs rēbus ${ }^{1}$ nactus ${ }^{2}$ idōneam ad nāvigandum tempestātem tertiā ferē vigiliā solvit, ${ }^{3}$ equitēsque in ulteriōrem portum ${ }^{4}$ prōgredī ${ }^{5}$ et nāvìs cōnscendere et sē sequī iussit. $\bar{A}$ quibus cum paulō tardius ${ }^{6}$ esset administrātum, ipse hōrā diēì circiter quārtā cum prīmīs nāvibus Britanniam attigit ${ }^{\top}$ atque ibi in omnibus collibus expositās hostium cōpiās armātās cōnspexit. Cuius locī haec ${ }^{8}$ erat nātūra, atque ita montibus ${ }^{9}$ anguste $\bar{e}^{10}$ mare continēbātur, utī ex locīs superiōribus in lītus tēlum adiḡi posset. Hunc ad ègrediendum nēquāquam idōneum locum arbitrātus, dum reliquae nāvēs eō convenīrent, ad hōram nōnam in ancorīs exspectāvit. Interim lēgātīs tribūnisque mìlitum convocātīs et quae ex Volusēnō ${ }^{11}$ cognōvisset et quae fierī vellet ostendit, monuitque, ut ${ }^{12}$ reī militāris ratiō, maximē ut ${ }^{122}$ maritimae rēs postulārent, ut quae celerem atque instabilem mōtum habērent, ad nūtum et ad tempus omnēs rēs ab iīs administrārentur. ${ }^{13}$ Hīs dīmissĩs et ventum et aestum ūnō tempore nactus secundum, datō signōo et sublātīs ancorīs circiter mìlia passuum septem ab eō locō prōgressus apertō ac plānō lìtore nāvīs cōnstituit. - De Bello Gallico, IV, 23

\section{VOCABULARY}

solvō, 3, solvī, solūtus, set sail expōnō, 3, posuī, positus, array nēquāquam, by no means adigō, 3, ègī, āctus, driz'e, hurl instabilis, e, unsteady 


\section{NOTES}

${ }^{1}$ his rēbus : i.e. preparations for the voyage. $\quad{ }^{2}$ nactus : having met with. ${ }^{3}$ solvit: probably from Portus Itius, which is perhaps the modern Boulogne, though some authorities identify it with Wissant, a town about ten miles from Calais. $\quad{ }^{4}$ portum : perhaps the harbor of Ambleteuse. $\quad{ }^{5}$ prōgredi : compare with ēgredior, noting the prefix. ${ }^{6}$ tardius: adverb. English derivative? ${ }^{7}$ Britanniam attigit: somewhere near Dover. ${ }^{8}$ haec: such. 9 montibus: cliffs. ${ }^{10}$ angustē: closely. ${ }^{11}$ Volusēnō: Cæsar had sent him ahead to find out what he could, but he had not dared to land. 12 ut, maximē ut: as, especially as. ${ }^{13}$ administrārentur: states the purpose of monuit.

\section{EXERCISE LXXVI}

Grammar: A. 349, $a$; 374, $a ; 410$. B. 204, I ; I 89,1 ; 2 I 8,1 . G. $374 ; 355 ; 407$. H. $450 ; 451$ I ; $431 ; 477$.

Inflection: ūtor; aqua; audācter.

Order of words: a prepositional phrase usually precedes the word which it limits.

THE OBSTACLES WHICH THE ROMANS FACE IN TRYING TO LAND

At barbarī cōnsiliō Rōmānōrum cognitō, praemissō equitātū et essedāriìs, ${ }^{1}$ quō plērumque ${ }^{2}$ genere in proelì̄s ùtì cōnsuērunt, reliquīs cōpiīs subsecūtī nostrōs nâvibus ègredī prohibēbant. Erat ob hās causās summa difficultās, quod nāvēs propter magnitūdinem nisi $^{4}$ in altō cōnstitui ${ }^{5}$ nōn poterant, mìlitibus ${ }^{6}$ autem ignōtīs locīs, impedìtīs manibus, magnō et gravī onere armōrum pressīs, simul et dē nāvibus dēsiliendum et in flūctibus cōnsistendum et cum hostibus erat pugnandum; cum illī $^{7}$ aut ex āridō aut paulum in aquam prōgressī, omnibus membrīs expedīî̄s, nōtissimīs locīs audācter tēla conicerent et equōs insuēfactōs incitārent. Quibus rēbus nostrī perterritī atque huius omnīnō generis pugnae imperîtī nōn eādem alacritāte ac studiō quō in pedestribus ùtī proelìis cōnsuērant ūtēbantur. - DE Bello Gallico, IV, 24 


\section{VOCABULARY}

\begin{abstract}
essedārius, essedārī, m., charioteer
\end{abstract}

membrum, i, n., limb insuēfactus, a, um, trained imperītus, a, um, unskilled alacritās, ātis, f., eagerness

\section{NOTES}

1 essedāriīs: understand praemissīs. $\quad{ }^{2}$ plērumque: synonym of maximē. ${ }^{3}$ subsecūtī: sub, closely. ${ }^{4}$ nisi: except. ${ }^{5}$ cōnstituĩ: be moored. ${ }^{6}$ militibus: with dēsiliendum, etc. $\quad 7$ illì : i.e. barbarī.

Think of English words from genere, prohibēbant, manibus, gravī, onere, flūctibus, alacritāte, and observe how the meaning of each is related to that of the Latin word.

\section{EXERCISE LXXVII}

Grammar: A, $3 S_{2}, \mathrm{I} ; 3{ }_{4} ; 563, a$. B. I9I, 2, $a$; I92, I ; 295, I, $a$. G. 356 , R. $3 ; 359 ; 423,2$, N. 6 . H. $433 ; 434,2 ; 565,3$.

Inflection: cunctor; mare; expeditior.

Order of words: the antecedent of a relative is usually placed immediately before it.

\section{CASAR, IN FORCING BACK THE ENEMY, IS HELPED BY \\ THE BRAVE ACT OF A ROMAN SOLDIER}

Quod $^{1}$ ubi Caesar animadvertit, nāvīs longās, quārum et speciēs erat barbarīs inūsitātior et mōtus ad ūsum expedītior, paulum removērī ${ }^{2}$ ab onerārīis nāvibus et rēmīs incitārī et $\mathrm{ad}^{3}$ latus apertum hostium cōnstituī, ${ }^{4}$ atque inde fundīs, sagittīs, tormentīs hostīs prōpellī ac submovērī iussit ; quae rēs magnō ūsuī nostrīs fuit. Nam et nāvium figūrā ${ }^{\bar{s}}$ et rēmōrum mōtū et inūsitātō genere tormentōrum permōtī barbarī cōnstitērunt ac paulum etiam pedem rettulērunt. ${ }^{6}$ Atque nostrīs mīlitibus cunctantibus, maximē propter altitūdinem maris, quī decimae legiōnis aquilam ${ }^{8}$ ferēbat, obtestātus deōs ut ea rēs legiōnī fēlīciter ēvenīret, "Dēsilìte," inquit, ${ }^{9}$ " commilitōnēs, nisi vultis aquilam hostibus prōdere; ego certē meum reì pūblicae atque imperātōrī officium praestiterō." Hoc cum vōce magnā 
dỉxisset, sē ex nāvī prōiēcit atque in hostīs aquilam ferre coepit. Tum nostrī cohortātī inter sē nē tantum dēdecus admitterētur ūniversīi $^{10}$ ex nāvī dēsiluērunt. Hōs item ex proximīs nāvibus cum cōnspexissent, subsecūtī hostibus appropinquāvērunt.

De Bello Gallico, IV, 25

\section{VOCABULARY}

inūsitātus, a, um, unusual

funda, ae, f., sling

tormentum, i, n., military engine prōpellō, 3, puli, pulsus, force back submoveō, 2, mōvī, mōtus, driz'e off obtestor, I, appeal to deus, i, m., god

fēlīiter, luappily

commīlitō, ōnis, m., fellow soldier prōdō, 3. didi, ditus, betray'

meus, a, um, my, mine

admittō, 3, mīsī, missus, permit

\section{NOTES}

1 quod: i.e. the difficulty of landing. ${ }^{3}$ ad: off. $\quad{ }^{4}$ connstitui : to be moored.

2 removērì : depends on iussit. English derivative? $\quad{ }^{6}$ pedem rettuleerunt: fell back. ${ }^{7}$ qui : the antecedent is the subject of inquit below. ${ }^{8}$ aquilam: the standard of the legion. ${ }^{9}$ inquit: synonym of dicō. ${ }^{10}$ ūniversĩ : adjective. English derivative?

\section{EXERCISE LXXVIII}

Grammar: A. $315, c ; 370$. B. 253, 2: 187 , III. G. $319 ; 347$. H. 5 I6, I; 429 .

Inflection: possum: litus; alius.

Order of words: prepositions regularly precede the words which they govern.

AFTER A SHARP FIGHT C.ESAR MAKES A LANDING AND ROUTS THE ENEMY

Pugnātum est ${ }^{1}$ ab utrīsque ācriter. Nostrī tamen, quod neque ōrdinēs servāre neque fīrmiter inssistere ${ }^{2}$ neque signa subsequī poterant, atque alius aliā ex nāvī quibuscumque signis occurrerat sē aggregābat, magnopere perturbābantur; hostēs vērō nōtīs 
omnibus vadīs, ubi ex lītore ${ }^{3}$ aliquōs singulārīs ex nāvì ègredientīs cōnspexerant, incitātīs equîs impedîtōs adoriēbantur, plūrēs paucōs

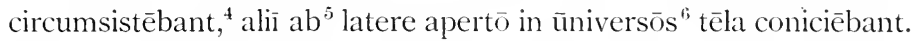
Quod cum animadvertisset Caesar, scaphās longārum nāvium, item speculātōria nāvigia mīlitibus complērī iussit, et quōs ${ }^{7}$ labōrantīs cōnspexerat, hīs subsidia submittēbat. Nostrī simul in āridō cōnstitērunt, suīs omnibus cōnsecūtīs in hostīs impetum fēcērunt atque eōs in fugam dedērunt; neque longius prōsequī potuērunt, quod equitēs cursum tenēre atque īnsulam capere nōn potuerant. Hoc ūnum ad prīstinam fortūnam Caesarì dēfuit.

$$
\text { De Beldo Gallico, IV, } 26
$$

\section{VOCABULARY}

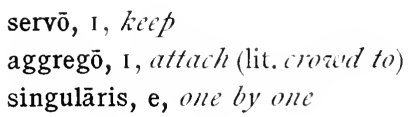

$$
\begin{aligned}
& \text { scapha, ae, f., skiff } \\
& \text { speculātōrius, a, um, spy } \\
& \text { nāvigium, nāvi'gī, n., boctt }
\end{aligned}
$$

\section{NOTES}

1 pugnātum est: translate by a personal form. . 2 insistere: synonym of cōnsistō. $\quad{ }^{3}$ ex litore: with cōnspexerant. ${ }^{4}$ circumsistēbant: compare with insistō and cōnsistō. $\quad 5 \mathrm{ab}$ : on. ${ }^{6}$ ūniversōs: the main bodly. ${ }^{7}$ quōs: the antecedent is hìs.

Think of English words from aggregābat, cōnspexerant, incitātis, latere, apertōo, subsidia, āridō, insulam, and observe the connection in meaning between the Latin word and the English derivative.

The Britons ask for peace after the first battle, but again renew hostilities. Cæsar defeats them, but a storm and the tide damage his fleet, and, after receiving offers of peace once more, he returns to Gaul.

\section{EXERCISE LXXIX}

Grammar: A. 382,$1 ; 500,4 ; 531,2$. B. 191,$1 ; 337,8, b, 2 ; 382,2$. G. $356 ; 430 ; 630$. H. $433 ; 622 ; 590$.

Inflection: reficiō ; aestus; humilior.

Order of words: a genitive, unless emphatic, usually follows the noun which it limits. 
CAEAR GIVES ORDERS FOR THE BUILDING OF A FLEET, AND THEN SETTLES A QUESTION OF DAMAGES WITH TIE PIRUSTE

Lūiciō Domitiō, Appiō Claudiō cōnsulibus discēēens ab hỉbernīs Caesar in İtaliam, ut quotannīs facere cōnsuērat, lēgātīs imperat, quōs legiōnibus praefēcerat, utī quam plūrimās possint hieme nāvīs aedificandās ${ }^{1}$ veterēsque reficiendās cūrent. Eārum modum fōrmamque ${ }^{2}$ dēmōnstrat. Ad celeritātem onerandī subductiōnisque paulō facit humiliōrēs quam quibus ${ }^{3}$ in nostrō marì ūtì cōnsuēvimus, atque id $e^{4}{ }^{4}$ magis, quod propter crēbrās commūtātiōnēs aestuum minus magnōs ibi flūctūs fierī ${ }^{5}$ cognōverat; ad onera ac multitūdinem iūmentōrum trānsportandam paulō lātiōrēs quam quibus in reliquīs ūtimur maribus. Hās omnis āctuāriās imperat fierī, quam ad rem multum humilitās ${ }^{6}$ adiuvat. Ea quae sunt ùsuī ad armandās nāvīs ex Hispāniā apportārīi iubet. Ipse conventibus ${ }^{8}$ Galliae citeriōris perāctīs in Îllyricum proficìscitur, quod à Pīrustīs fīnitimam partem prōvinciae incursiōnibus vāstārī audiēbat. Eō cum vēnisset, cìvitātibus mìlitēs imperat ${ }^{9}$ certumque in locum convenìre iubet. (Quaā rē nūntiātā Pìrustae lēgătōs ad eum mittunt, quì doceant nihil eārum rērum pūblicō factum cōnsiliō, sēsēque parātōs esse dēmōnstrent omnibus ratiōnibus dē iniūriīs satisfacere. Perceptā ${ }^{10}$ ōrātiōne eōrum Caesar obsidēs imperat eōsque ad certam diem addūcì iubet; nisi ita fēcerint, sēsē bellō civitātem persecūtūrum dēmōnstrat. Iīs ad diem adductìs, ut imperāverat, arbitrōs inter cīvitātēs dat, quī lìtem aestiment poenamque cōnstituant.

De Bello Gallico, V, I

\section{VOCABULARY}

quotannīs, eavery year

onerō, I, load

subductiō, önis, f., beaching

iümentum, i, n., beast of burden

āctuārius, a, um, stuift

incursiō, ōnis, f., raid satisfaciō, 3, fēcī, factus, giz'e satisfaction

arbiter, trī, m., referee

lis, litis, f., damages

aestimō, I, assess

poena, ae, f., penalty 


\section{NOTES}

1 nāvīs aedificandās: Cæsar intended to make a second expedition to Britain. 2 fōrmam: English derivative? $\quad{ }^{3}$ quibus : understand eās as antecedent. $\quad{ }^{4}$ ē̃ : for this reason. ${ }^{5}$ fierī: become. ${ }^{6}$ humilitās : derivation? ${ }^{7}$ apportārī : ad + portō. ${ }^{8}$ conventibus: the courts of justice over which the provincial governor presided. ${ }^{9}$ imperat: lev'ies. ${ }^{10}$ perceptā: synonym of cognōscō.

Think of English words from aedificandās, onera, conventibus, doceant, arbitrōs, aestiment, and observe how the meaning of the Latin word helps to make plain the meaning of the English.

Six hundred ships of the kind described above and twenty-eight war vessels are built for Cæsar. He orders them to assemble at Portus Itius, ready for the passage to Britain. He himself with four legions and eight hundred horsemen invades the land of the Treveri, who have disregarded his commands.

\section{EXERCISE LXXX}

Grammar: A. 4IS; 564: 580. B. $226: 296,2$; 314, I. G. 397 ; $550,1,2 ; 650$. H. 4 So: 567.1 ; 642:643.

Inflection: ostendō; fidēs; alter.

Order of words: the following arrangement of the modifiers of a verb is common : ablative, indirect object, direct object, adverb, unless changed by emphasis.

HOW THE TWO CHIEFS OF THE TREVERI ACTED ON C.SSAR'S ARRIVAL IN THEIR TERRITORY

Haec cìvitās ${ }^{1}$ longē plūrimum² tōtīus Galliae equitātū valet magnāsque habet côpiās peditum, Rhēnumque, ut suprā dēmōnstrāvimus, tangit. In eā cīvitāte duo dē prīncipātū inter sē contendēbant, Indūtiomārus et Cingetorīx; ex quibus alter, simul atque $^{3}$ dë Caesaris legiōnumque adventū cognitum est, ad eum ${ }^{4}$ vēnit, sē suōsque omnīs in officiō futūrōs neque ab amīcitiā populī Rōmānī dēfectūrơs cōnfīrmāvit, quaeque in Trēverīs gererentur ostendit. $\mathrm{At}^{5}$ Indūtiomārus equitātum peditātumque cōgere, ī̄sque quī per aetātem in armīs esse nōn poterant in silvam Arduennam ${ }^{6}$ 
abditīs, quae ingentī magnitüdine ${ }^{7}$ per mediōs fīnīs Trēverōrum à flūmine Rhēnō ad initium Rēmōrum pertinet, bellum parāre instituit; sed posteāquam ${ }^{8}$ nōn nūlli prīncipēs ex eā civitāte et auctōritāte Cingetorīgis adductī et adventū nostrī exercitūs perterritī ad Caesarem vēnērunt et dē suìs prīvātīs rēbus ab eō petere coepērunt, quoniam cìvitātī cōnsulere ${ }^{9}$ nōn possent, veritus nē ab omnibus dēsererētur lēgātōs ad Caesarem mittit ${ }^{10}$ : Sēsē idcircō ab suīs discēdere atque ad eum venìre nōluisse, quō ${ }^{11}$ facilius civitātem in officiō continēret, nē omnis nōbilitātis discessū plēbs propter imprūdentiam lāberētur; itaque cìvitātem in suā potestāte esse, sēque, sì Caesar permitteret, ad eum in castra ventūrum et suās cīvitātisque fortūnās eius fideî permissūrum. - I)E Bello Gallico, V', 3

\section{VOCABULARY}

tangō, 3, tetigī, tāctus, touch prīncipātus, ūs, m., leadership aetās, ātis, f., age ingēns, ingentis, huge idcircō, for this reason plēbs, plēbis, f., common people lābor, 3, lāpsus, go wrong

NOTES

1 civitās: i. e. that of the Trēverī. $\quad{ }^{2}$ plūrimum: with valet; is the strongest. ${ }^{3}$ simul atque: as soon as. ${ }^{4}$ eum: Casar. ${ }^{5}$ at: synonym of sed. ${ }^{6}$ Arduennam: of Ardennes. ${ }^{7}$ magnitūdine: describes quae. ${ }^{8}$ posteāquam: = postquam. $\quad{ }^{9}$ connsulere: with dative, look out for. ${ }^{10}$ mittit: the subject refers to Indūtiomārus. ${ }^{11}$ quō: introduces a purpose clause containing a comparative.

Explain the derivation of adventū, amīcitiā, magnitūdine, imprūdentiam.

Cæsar arranges matters with the leaders of the Treveri and goes to Portus Itius, where he finds the fleet ready for him, with the exception of sixty ships that have been held back by a storm. The chief men of all the states have also assembled there, and most of these he decides to take with him as hostages, fearing an uprising in Gaul while he is away. 


\section{EXERCISE LXXXI}

Grammar: A. 345; 349, a; 504, b. B. 203, I; 204, I; 338, I, a, $c$. G. $365 ; 374 ; 428,2$. H. 440,$3 ; 451,1 ; 475,2 ; 626$.

Inflection: audeō; commūnis; ille.

Order of words: adjectives of quantity, being emphatic, usually precede the word which they modify.

\section{DUMNORIX IS RELUCTANT TO ACCOMPANY CASAR TO BRITAIN}

Erat ūnā cum cēterīs ${ }^{1}$ Dumnorīx Aeduus, dē quō ante ā nōbīs dictum est. Hunc sēcum habēre in prīmīs cōnstituerat, quod eum cupidum rērum novārum, cupidum imperī, magnī animī, magnae inter Gallōs auctōritātis cognōverat. Accēdēbat hūc ${ }^{2}$ quod $^{3}$ in conciliō Aeduōrum I)umnorīx dīxerat sibi ā Caesare rēgnum cìvitātis dēferrī ; quod dictum ${ }^{\star}$ Aedū graviter ferēbant neque recūsandī aut dēprecandi causā lēgātōs ad Caesarem mittere audēbant. Id factum ex suīs hospitibus Caesar cognōverat. Ille omnibus prīmō precibus petere contendit ut in Galliā relinquerētur, partim ${ }^{5}$ quod insuētus nāvigandī mare timēret, partim quod religiōnibus impedīī sēsē dīceret. Posteāquam ${ }^{6}$ id obstinātēe ${ }^{7}$ sibi negārī vīdit, omnī spē impetrandī adēmptā prīncipès Galliae sollicitāre, sêvocāre singulōs hortārīque coepit utī in continentī remanērent; metū territāre ${ }^{8}$ : Nōn sine causā fierī ut Gallia omnī nōbilitāte spoliārētur; id esse cōnsilium Caesaris, ut quōs ${ }^{9}$ in cōnspectū Galliae interficere verēerētur, hōs omnìs in Britanniam trāductōs necāret ${ }^{10}$; fidem reliquīs interpōnere, ${ }^{11}$ iūs iūrandum poscere, ut quod esse ex $\bar{u} \overline{s u}^{12}$ Galliae intellēxissent commūnī cōnsiliō administrārent. Haec à complūribus ad Caesarem dēferēbantur. - I e Bello Gallico, V, 6

\section{VOCABULARY}

dēprecor, I, beg off

insuētus, a, um, unacoustomed

religiō, ōnis, f., scruple

negō, I, refuse sollicitō, I, stir up sēvocō, I, call aside territō, I, temify' spoliō, 1, flunder 


\section{NOTES}

1 cêteris: synonym of reliqui, referring to those who were going with Cæsar. ${ }^{2}$ hūc: to this. ${ }^{3}$ quod: the fact that. ${ }^{4}$ dictum: a noun, referring to sibi ... dēferri. $\quad{ }^{5}$ partim: adverb from pars. ${ }^{6}$ posteāquam: = postquam. $\quad{ }^{7}$ obstinātē: observe the termination. English derivative? 8 territāe: depends on coepit. It implies an idea of saying, on which fierĭ and esse depend. ${ }^{9}$ quōs: the antecedent is hōs. 10 necāret: synonym of interficiō. 11 interpōnere: to pledge. It depends on coepit. $\quad 12$ ex ūsū: of advantage.

Observe the force of the prefix in dēferrī, insuētus, sēvocāre, interpōnere.

\section{EXERCISE LXXXII}

Grammar: A. $346, a .3: 367: 496$. B. 187 . II, a: 201, 2: 337,2 , a,f. G. $369: 346: 665 ; 666$. H. $442 ; 426, \mathrm{I}: 638, \mathrm{1}$.

Inflection: coepī : cōnsilium; lïber.

Order of words: the modifiers of a word precede or follow it, according as they are, or are not, emphatic.

DURING TIIE EMBARKATION DLMNORIX ATTEMPTS TO ESCAPE, BUT IS OVERTAKEN ANI PUT TO DEATII

Quā rể cognitā Caesar, quod tantum cìvitātī Aeduae dignitātis ${ }^{2}$ tribuēbat, coercendum ${ }^{3}$ atque dēterrendum quibuscumque rēbus posset Dumnorīgem statuēbat; quod longius eius āmentiam prōgredī vidēbat, prōspiciendum nē quid ${ }^{4}$ sibi ac rē̄ pūblicae nocēre posset. Itaque diēs circiter vīgintī quinqque in eō locō commorātus, ${ }^{5}$ quod Cōrus ${ }^{6}$ ventus nāvigātiōnem impediēbat, quī magnam partem omnis temporis in hìs locis flāre cōnsuēvit, dabat operam ${ }^{7}$ ut in officiō Dumnorīgem continēret, nihilō tamen sētius omnia eius cōnsilia coginōsceret; tandem idōneam nactus ${ }^{8}$ tempestātem mīlitēs equitēsque cōnscendere nāvīs iubet. At omnium impedīìs animīs Dumnorīx cum equitibus Aeduōrum à castrīs insciente ${ }^{9}$ Caesare domum discēdere coepit. Quā rē nūntiātā Caesar, intermissā profectiōne atque omnibus rēbus postpositīs, magnam partem equitātūs ad eum insequendum mittit retrahique imperat; sì vim faciat neque 
pāreat, interficī iubet, nihil ${ }^{10}$ hunc sē absente prō ${ }^{11}$ sānō factūrum arbitrātus, ${ }^{12}$ quī $^{13}$ praesentis imperium neglēxisset. Ille autem revocātus resistere ac sē manū dēfendere suōrumque fidem implōrāre coepit, saepe clāmitāns lỉberum sē lỉberaeque esse cívitātis. Illī, ut erat imperātum, circumsistunt hominem atque interficiunt; at equitēs Aeduī ad Caesarem omnēs revertuntur.

$$
\text { I) E Bello Gallico, } \mathrm{V}, 7
$$

\section{VOCABULARY}

tribuō, 3 , uī, ūtus, grant coerceō, 2, uī, itus, check ämentia, ae, f., madness prōspiciō, 3, spexī, spectus, look out flō, 1, blow sētius, less retrahō, 3, trāxī, trāctus, bring back pārēo, 2, uī, — obè sānus, a, um, sane' revocō, i, recall clāmitō, I, shout

\section{NOTES}

1 quā rē: the facts mentioned in the last chapter. ${ }^{2}$ dignitātis: with tantum. English derivative? ${ }^{3}$ coercendum: understand esse, depending on statuēbat. $\quad{ }^{4}$ quid: in any zi'ay'. ${ }^{5}$ commorātus: synonym of moror. ${ }^{6}$ Cōrus: the northwest wind. $\quad{ }^{7}$ dabat operam: he exerted himself. ${ }^{8}$ nactus: having met. $\quad{ }^{9}$ insciente: in + sciēns. $\quad{ }^{10}$ nihil: object. ${ }^{11}$ prō: like. 12 arbitrātus : synonym of existimō. $\quad{ }^{13}$ quī: equivalent to cum causal.

Think of English words from tribuēbat, dēterrendum, prōspiciendum, revocātus, revertuntur, and observe the connection in meaning between the Latin word and the English derivative.

Cæsar sets sail at sunset and with the enthusiastic help of sailors and soldiers reaches Britain the next day about noon. IIe lands without mishap. Learning the location of the enemy, he sets out at once for them, but has no decisive engagement.

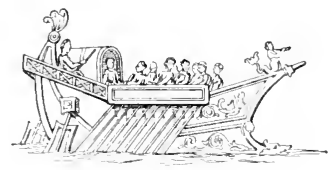

NAVIGIUMI 


\section{EXERCISE LXXXII}

Grammar: A. $346, a, 3: 531,2$ : 540, 2. B. $201,2: 282,2 ; 286,1$. G. 369:630:54I. H. $442: 590: 588$, II.

Inflection: nūntiō: diēs : superus (compare).

Order of words: temporal clauses usually precede, clauses of purpose and result usually follow, the verb on which they depend.

\section{A STORM CALSES A IISASTER TO THE FLEET}

Postrīdiē eius diēî ${ }^{1}$ māne tripartîtō mìlitēs equitēsque in expedītiōnem ${ }^{2}$ mīsit, ut eōs quī fūgerant persequerentur. ${ }^{3}$ Hìs aliquantum itineris prōgressīs, cum iam extrēmì essent in prōspectū, equitēs ā Quīntō Ātriō ad Caesarem vēnērunt, quī nūntiārent superiōre nocte maximā coortā tempestāte prope omnìs nāvīs afflìctās atque in lìtus èiectās esse, quod neque ancorae fūnēsque sustinērent neque nautae gubernātōrēsque vim tempestātis patì possent; itaque ex eō concursū nāvium magnum esse incommodum ${ }^{4}$ acceptum.

$$
\text { De Bello Gallico, V, io }
$$

\section{VOCABULARY}

māne, carly'

tripartitō, in thrét dizisions

aliquantum, i, n., a little prōspectus, ūs, m., r'ie

èiciō, 3. iēcī, iectus, throw out

\section{NOTES}

1 eius diēi: i.e. on which his soldiers had put the enemy to flight. ${ }^{2}$ expeditiōnem: expediō + tiō ; raid. ${ }^{3}$ persequerentur: composition? ${ }^{4}$ incommodum: the prefix has a negative force. 


\section{EXERCISE LXXXIV}

Grammar: A. $345 ; 382$, I 504. B. 203, I ; I9I, I; 338 , I, a. G. 365 ; $356 ; 428$. H. 440,$3 ; 433 ; 626$.

Inflection: mūniō; maior; ìdem.

Order of words: modifiers of either word of an ablative absolute often are placed between these words, the particular arrangement depending on the emphasis.

CESAR PROCURES WORKMEN, REPAIRS THE DAMAGE, AND STARTS AGAIN

Hìs rēbus ${ }^{1}$ cognitīs Caesar legiōnēs equitātumque revocārī atque in itinere resistere iubet, ipse ad nāvīs revertitur; eadem ferēe quae ex nūntī̄s litterīsque cognōverat cōram perspicit, ${ }^{3}$ sīc ut āmissīs circiter quadrāgintā nāvibus reliquae tamen reficī posse magnō negōtio ${ }^{4}$ vidērentur. Itaque ex legiōnibus fabrōs dēligit et ex continentī aliōs arcessī jubet; Labiēnō scrībit ${ }^{5}$ ut ${ }^{6}$ quam plūrimās possit ī̄s legiōnibus quae sint apud eum nāvīs instituat. Ipse, etsī rēs erat multae operae ${ }^{\bar{\lambda}}$ ac labōris, tamen commodissimum esse statuit omnīs nāvīs subdūcī et cum castrīs ūnā mūnītiōne coniungī. ${ }^{8}$ In hīs rēbus circiter diēs decem cōnsūmit nē nocturnīs ${ }^{9}$ quidem temporibus ad labōrem mīlitum intermissīs. Subductīs nāvibus castrīsque êgregiē mūnītīs eāsdem cōpiās quās ante praesidiō nãvibus relinquit; ipse eōdem unde redierat proficīscitur. Eō cum vēnisset, maiōrès iam undique in eum locum cōpiae Britannōrum convēnerant summā ${ }^{10}$ imperī bellīque administrandì commūnī cōnsiliō permissā Cassivellaunō, cuius fīnīs ā maritimīs ${ }^{11}$ cìvitātibus flūmen dīvidit, quod appellātur Tamesis, ${ }^{12}$ ā marī circiter mìlia passuum octōgintā. Huic $^{13}$ superiōre tempore cum reliquīs civitātibus continentia bella intercesserant; sed nostrō adventū permōtī Britannī hunc tōtỉ bellō imperiōque praefēcerant. - De Bello Gallico, V, i I

\section{VOCABULARY}

revocō, I, recall

faber, brī, m., workman 


\section{NOTES}

${ }^{1}$ his rēbus: i.e. the disaster to the fleet. placed next to the word which it modifies.
${ }^{4}$ negōtiō: shows the

${ }^{6}$ ut: introduces instituat. implies an order.

8 omnis . . coniungi : forms the subject of esse.

${ }^{10}$ summā: a noun. pertaining to.

taining to.

12 Tamesis: the Thames.
2 ferē : an adverb is usually ${ }^{3}$ perspicit: compare with of the great heroes of ancient Britain.

\section{EXERCISE IXXXV}

Grammar: A. $2 S_{3} ; 2 S_{4} ; 4_{4} ;{ }_{4} 8$. B. $167 ; 168 ; 223: 226$. G. 205 ; 2I I 403: 397. H. 393: 479; 480.

Inflection: appellō (3): insula; ūnus.

Order of words: the modifiers of the predicate are usually arranged, from the beginning. in the order of their importance.

TIE SIZE AND SIIAPE OF THE BRITISII ISLANDS

Īnsula ${ }^{1}$ nātūrā triquetra, cuius ūnum latus est contrā² Galliam. Huius lateris alter angulus, quī est ad Cantium, ${ }^{3}$ quō ferē omnēs ex Galliā nāvēs appelluntur, ad orientem sōlem, inferior ad merīdiem ${ }^{4}$ spectat. Hoc latus tenet ${ }^{5}$ circiter milia passuum quingenta. Alterum vergit ad Hispāniam atque occidentem sōlem; quā ex ${ }^{6}$ parte est Hibernia insula, dỉmidiō minor, ut exīstimātur, quam Britannia, sed parī spatiō trānsmissūs atque ${ }^{\top}$ ex Galliā est in Britanniam. In hōe mediō cursū est insula, quae appellātur Mona ; complūrēs praetereā minōrēes obiectae insulae exīstimantur, dē quibus însulīs nōn nūllī scrīpsērunt diès continuōs trīgintā sub ${ }^{8}$ brūmam esse noctem. Nòs nihil dè eồ percontātiōnibus reperiēbāmus, nisi certīs ex aquā $\bar{a}^{9}$ mēnsūrìs breviōrēs esse quam in continentī noctīs vidēbāmus. Huius est longitūdōo ${ }^{10}$ lateris, ut fert illōrum opiniō, septingentōrum milium. Tertium est contrā septentriōnēs, cui partī nülla est obiecta terra; sed eius angulus alter 
maximē ad Germāniam spectat. Hoc mīlium passuum octingentōrum in longitūdinem esse exīstimātur. I ta omnis insula est in circuitū vìciēs centum mïlium passuum. - I) E Bello Gallico, I', I 3

\section{VOCABULARY}

triquetrus, a, um, triangular angulus, $\bar{i}, \mathrm{~m}$., angle, corner dimidium, dimi'dì, n., half trānsmissus, ūs, m., crossing scrībō, 3, scrīpsī, scrīptus, write brūma, ae, f., winter solstice (lit. shortest) percontātiō, ōnis, f., inquiry' mēnsūra, ae, f., measurement vìciēs, twenty times

\section{NOTES}

1 insula: understand the verb. $\quad{ }^{2}$ contrā: offosite. $\quad{ }^{3}$ Cantium: Kinnt. ${ }^{4}$ ad meridiem: is this true? Merīiem $=$ medius + diēs. $\quad{ }^{5}$ tenet: extends. ${ }^{6} \mathrm{ex}$ : on. $\quad$ ' atque : as. ${ }^{8} \mathrm{sub}$ : about. ${ }^{9}$ ex aquā: i.e. by means of the water-clock. ${ }^{10}$ longitū $\mathrm{d} \overline{\mathrm{l}}$ : composition?

Think of English words from orientem, sōlem, occidentem, obiectae, spectat, centum, and observe the connection in meaning between the Latin word and the English derivative.

\section{EXERCISE LXXXVI}

Grammar: A. 415: 418. B. 224: 226. (I. 400: 397. H. 473. 2 ; 4 SO. Inflection: efficiō: lac; multum (compare).

Order of words: a preposition is usually placed immediately before the word which it governs.

\section{SOME OF TIIE CUSTOMS OF THE BRITONS}

Ex hīs ${ }^{1}$ omnibus longē sunt hūmānissimī² quī Cantium incolunt. quae regiō est maritima omnis, neque multum à Gallicā differunt cōnsuētūdine. Interiōrēs ${ }^{3}$ plērīque frūmenta nōn serunt, sed lacte et carne vìvunt pellibusque sunt vestītī. Omnēs vèrō sē Britannī vitrō inficiunt, quod caeruleum efficit colōrem, ${ }^{4}$ atque hōc ${ }^{j}$ horribiliōrēs ${ }^{6}$ sunt in pugnā aspectū ${ }^{7}$; capillōque sunt prōmissō atque omnī parte corporis rāsā praeter caput et labrum superius.

$$
\text { I) Beldo Galaico, I, I } 4
$$




\section{VOCABULARY}

serō, 3. sēvī, satus, sow vìvō, 3, vīxī, vīctum, liz'e vestiō, + , ìvi, itus, clothe vitrum, i, n., woad, a blue dye inficiō, 3, fēcī, fectus, stain caeruleus, a, um, blue capillus, i, m., hair prōmittō, 3. mīsī, missus, let grow rāsus, a, um, shaved labrum, i, n., lip

\section{NOTES}

${ }^{1}$ hìs: i.e. Britannī. ${ }^{2}$ hūmānissimī: homōo + ānus, pertaining to. ${ }^{3}$ interiōrēs: English derivative? Understand hominēs. ${ }^{4}$ colōrem: English derivative? $\quad{ }^{5}$ hōc: states a cause. ${ }^{6}$ horribiliōrēs: English derivative from the positive? ${ }^{7}$ aspectū : compare conspectus, noting the prefix.

\section{EXERCISE LXXXVII}

Grammar: A. $3+5 . a: 414: 429$, I. B. $203, \mathrm{I} ; 223 ; 228, \mathrm{I}, b$. G. 365 ; to3: 355. N. 1. H. +40.3: $479: 485.2$.

Inflection: ē̄: genus: alter.

Order of words: a genitive, unless emphatic, usually follows the noun which it limits.

C.SAR CROSSES THE THAMES IN SPITE OF TIIE ENEMY'S RESISTANCE

Caesar cognitō cōnsiliōo ${ }^{1}$ eōrum² ad flūmen Tamesim in fīnīs Cassivellaunī ${ }^{3}$ exercitum dūxit; quod flūmen ūnō omnīnō locō pedibus, atque hōc aegrēê, trānsīrī potest. ${ }^{\star}$ Eō cum rēnisset, animadvertit ad alteram flūminis rīpam magnās esse cōpiās hostium instrūctās. Rīpa autem erat acūtīs sudibus praefixīsque mūnita, eiusdemque generis sub aquā dēfīxae sudēs flümine tegēbantur. Hìs rèbus cognitìs à captî̀ìs perfugīsque Caesar praemissō equitātū cōnfestim legiōnēs subsequī iussit. Sed eā celeritāte atque eō impetū militēs iērunt, cum ${ }^{6}$ capite sōlō ex aquā exstārent, ut hostēs impetum legiōnum atque equitum sustinēre nōn possent rīpāsque dīmitterent ac sé fugae mandārent. - De Bello Gallico. V', i $S$ 


\section{VOCABULARY}

sudis, is, f., stake

praefīgō, 3 , fīxì, fīxus, set up

in front tegō, 3 , tēxī, tēctus, con'er

perfuga, ae, m., deserter

exstō, I, —, , stand out

\section{NOTES}

${ }^{1}$ cōnsiliō: i.e. of fighting. ${ }^{2}$ eōrum: the Britons. ${ }^{3}$ Cassivellaunī: one of the greatest of the ancient heroes of Britain. ${ }^{4}$ flūmen . . potest: not true; Cæsar found but one. $\quad{ }^{5}$ eā: $=\operatorname{tantā~here.~} \quad{ }^{6}$ cum: conjunction. Considering the phrase capite sōlō with eā celeritāte iērunt, what force must cum have?

Determine the force of the prefix in praefīxis, dēfīxae, subsequī, exsstārent, dimitterent.

Cassivellaunus continues the warfare by attacking the Romans' foraging parties, and thus keeping them from going far from the camp in the search for supplies.

\section{EXERCISE LXXXVIII}

Grammar: A. 305 ; 563. B. 250 , I : 295, I. G. 6I 4 : 546 . H. 396 ; 565.

Inflection: dēfendō: celeriter (compare): ipse.

Order of words: an adverb is usually placed immediately before the word which it limits.

\section{THE TRINOVANTES SURRENDER TO CASAR}

Interim Trinovantēs, prope fīrmissima eãrum regiōnum cīvitās, ex quā Mandubracius adulēscēns Caesaris fidem secūtus ad eum in continentem vēnerat, cuius pater in eā cīvitāte rēgnum obtinuerat interfectusque erat ā Cassivellaunō, ipse ${ }^{1}$ fugā mortem vitāverat, lēgātōs ad Caesarem mittunt pollicenturque sēsē eì dēditūrōs atque imperāta factūrōs ; petunt ut Mandubracium ab iniūriā Cassivellauñ̄ dēfendat atque in cīvitātem mittat, quī² praesit imperiumque obtineat. His Caesar imperat obsidēs quadrāgintā frūmentumque exercituī, Mandubraciumque ad eōs mittit. ${ }^{3}$ Illī imperāta celeriter lècērunt, obsidēs ad numerum frūmentumque misērunt.

$$
\text { De Bello Gallico, V, } 20
$$




\author{
VOCABULARY \\ continëns, entis, f., continent \\ vìtō, I, az'oid
}

NOTES

1 ipse: Nandubracius. 2 qui, etc.: states the purpose of mittat. ${ }^{3}$ Mandubracium . . mittit: by this means he gained their good will.

\title{
EXERCISE IXXXIX
}

Grammar: A. 346, a, 3: 420, i, 2; 556. B. 201,$2 ; 337,2, a, f$; 293, I. G. $369 ; 665 ; 666$. H. $442 ; 63 \$, 1 ; 604,1$.

Inflection: obses; nōbilis; hìc.

Order of words: dependent clauses, except those of purpose and result, tend to precede the main verb.

AFTER A LAST DESPERATE ATTEMPT TO DEFEAT THE ROMANS CASSIVELLAUNUS SLRRENDERS TO CASAR

Dum haec ${ }^{1}$ in hīs locīs geruntur, Cassivellaunus ad Cantium, ${ }^{2}$ quod esse $\mathrm{ad}^{3}$ mare suprā dēmōnstrāvimus, quibus regiōnibus ${ }^{4}$ quattuor rēgēs praeerant, Cingetorix, Carvilius, Taximagulus, Segovax, nūntiōs mittit atque hīs imperat utī coāctīs omnibus cōpiìs castra nāvālia dē imprōvīsō adoriantur atque oppugnent. Hì cum ad castra vēnissent, nostrī ēruptiōne factā, multīs eōrum interfectīs, captō etiam nōbilī duce Lugotorìge, suōs incolumìs redūxērunt. Cassivellaunus hōc proeliō nūntiātō, tot dètrīmentīs acceptīs, vāstātīs finibus, maximē etiam permōtus dēfectiōne cīvitātum ${ }^{5}$ lēgātōs per Atrebātem Commium dē dēditiōne ad Caesarem mittit. Caesar cum cōnstituisset ${ }^{6}$ hiemāre in continentī propter repentīnōs Galliae mōtūs, neque multum aestātis superesset, atque id facile extrahī posse intellegeret, obsidēs imperat et quid in annōs singulōs vectīgālis ${ }^{\overline{7}}$ populō Rōmānō Britannia penderet cōnstituit; interdīcit atque imperat Cassivellaunō nē Mandubraciō neu Trinovantibus noceat.

$$
\text { De Bello Gallico, V, } 22
$$




\section{VOCABULARY}

nāvālis, e, naz'al

dēfectiō, ōnis, f., rérolt

extrahō, 3 , trāxī, trāctus, draw out vectīgal, ālis, n., tribute

interdīcō, 3, dixīi, dictus, forbid

\section{NOTES}

1 haec: i. e. the capture of the chief town of Cassivellaunus. $\quad{ }^{2}$ Cantium: Lent. ${ }^{3}$ ad: near. ${ }^{4}$ regionnibus: for the case, consider praeerant. ${ }^{5}$ civitātum: five had surrendered to Cæsar. ${ }^{6}$ cōnstituisset: states a reason for imperat. ' ' vectīgālis : with quid.

Observe the words in the passage ending in tiō. What is the force of this suffix?

Cæsar then returns with his fleet safely to Gaul.

\section{EXERCISE XC}

Grammar: A. 403, a; 410. B. $215 ; 218,1$. G. $395: 407$. H. 469,2 ; 477 .

Inflection: fīō: plūs.

Order of words: the beginning of the clause or sentence is usually the emphatic position.

\section{CASAR LEARNS OF TIE MURIER OF TASGETIUS}

Erat in Carnutibus summō locōo nātus Tasgetius, cuius maiōrēs in suā cīvitāte rēgnum obtinuerant. Huic Caesar prō eius virtūte atque in sē benevolentiā, ${ }^{2}$ quod in omnibus bellīs singulārī ${ }^{3}$ eius operā $^{4}$ fuerat $^{5}$ ūsus, maiōrum locum restituerat. Tertium iam hunc ${ }^{6}$ annum rēgnantem ${ }^{7}$ inimìcī $^{8}$ palam multīs ex cīvitāte auctōribus ${ }^{9}$ interfēcērunt. Dēfertur ea rēs ad Caesarem. Ille veritus, quod ad plūrīs pertinēbat, ${ }^{10}$ nē civitās eōrum impulsūı dēficeret, Lūcium Plancum cum legiōne ex Belgiō celeriter in Carnutēs proficīscī iubet ibique hiemāre, quōrumque ${ }^{11}$ operā ${ }^{12}$ cognōverit Tasgetium interfectum, hōs comprehēnsōs ad sē mittere. Interim ab omnibus quibus legiōnēs trädiderat certior factus est in hïberna perventum locumque hïbernīs esse mūnītum. - I)E Bello Galdico, V, 25 


\section{VOCABULARY}

palam, openly

impulsus, ūs, m., instigation comprehendō, 3 , hendī, hēnsus, seize

\section{NOTES}

${ }^{1}$ locō: rank. ${ }^{2}$ benevolentiā : bene + volōo + tia. $\quad{ }^{3}$ singulārī : English derivative? ${ }^{4}$ operā : synonym of opus. ${ }^{5}$ fuerat: translate as erat. ${ }^{6}$ hunc: refers to Tasgetius. $\quad{ }^{7}$ rēgnantem: synonym of regō. $\quad{ }^{8}$ inimīcī : in + amīcus. ${ }^{9}$ auctōribus: auge $\overline{0}+$ tor, instigators. ${ }^{10}$ ad plūrīs pertinēbat: i.e. several persons were concerned in it. Note multīs auctōribus above. 11 quōrum: the antecedent is hōs. 12 operā: with interfectum.

Ambiorix, one of the chiefs of the Eburones, incites a serious revolt among several of the Gallic tribes, the Nervii among others. The winter quarters of Cicero, the commander of Cæsar's forces in this tribe, are besieged, and the situation is critical. Cicero gets a letter through the enemy's lines to Cæesar, and the latter at once marches to his relief with what troops he can gather.

\section{EXERCISE XCI}

Grammar: A. $3+5 ; 376 ; 531,2$. B. 203,$1 ; 188,1 ; 282,2$. G. 365 ; 352; 630. H. 440, 3; 425, 2 .

Inflection: cōnfîrmō; mîlle; certior.

Order of words: a variation from the usual position of a word makes the word emphatic.

\section{LEARNING OF THE GALLS' AINANCE, CASAR PURPOSELY BUILIS A VERY SMALL CAMP TO LURE THEM ON}

Gallī rē cognitā ${ }^{1}$ per explōrātōrēs obsidiōnem relinquunt, ad Caesarem omnibus côpiīs contendunt. Haec ${ }^{2}$ erant armāta circiter mìlia sexāgintā. Cicerō datā facultāte Gallum ${ }^{3}$ ab eōdem Verticōne quem suprā dēmōnnstrāvimus repetit, ${ }^{4}$ quī litterās ad Caesarem dēferat. Hunc admonet ${ }^{5}$ iter caute $\bar{e}^{6}$ diligenterque faciat. ${ }^{7}$ Perscrībit in litterīs hostīs ab sē discessisse omnemque ad eum multitūdinem convertisse. Quibus litterīs circiter mediā nocte Caesar adlātīs suōs 
facit certiōrēs eōsque ad dīmicandum animō cōnfīrmat. Posterō diē lūce prīmā movet castra, et circiter mīlia passuum quattuor prōgressus trāns vallem et rīvum multitūdinem hostium cōnspicātur. Erat magnī perìculī rēs tantulīs cōpiīs iniquuō ${ }^{8}$ locō dìmicāre ${ }^{9}$; tum, quoniam obsidiōne lỉberātum ${ }^{10}$ Cicerōnem sciēbat, aequō animōo remittendum dē celeritāte ${ }^{11}$ exīstimābat. Cōnsìdit et quam aequissimō potest locō castra commūnit ${ }^{12}$; atque haec etsĩ erant exigua ${ }^{13}$ per sē, vix hominum milium septem, praesertim nūllìs cum impedímentīs, tamen angustīis viārum ${ }^{14}$ quam maximē potest contrahit e⿳亠丷厂 cōnsiliō, ut in summam contemptiōnem ${ }^{15}$ hostibus veniat. Interim speculätōribus in omnīs partīs dīmissĩs explōrat quo ${ }^{16} \mathrm{commodissimē}$ itinere vallem trānsỉre possit. - DE Bello Gallico, I, 49

\section{VOCABULARY}

perscrībō, 3, scrīpsī, scrīptus,

write in full

rìvus, ì, m., stream tantulus, a, um, so little

speculātor, ōris, m., spy'

\section{NOTES}

${ }^{1}$ rē cognitā: i.e. the fact that Cresar was coming to the relief of Cicero. ${ }^{2}$ haec: refers to cōpiīs, but takes the gender of milia. $\quad{ }^{3}$ Gallum: a slave of Vertico, a Nervian. He had helped Cicero before. ${ }^{4}$ repetit: composition? $\quad{ }^{5}$ admonet : = monet. $\quad{ }^{6}$ cautē : adverb from the participle of caveō. $\quad{ }^{7}$ faciat: shows purpose. $\quad{ }^{8}$ inīquō: in + aequus. $\quad{ }^{9}$ dīmicāre : used as a noun. ${ }^{10}$ liberātum: verb formed from lïber. Inderstand esse. ${ }^{11}$ remittendum de celeritāte: he misht relax his sfect. ${ }^{12}$ commūnit: the prefix is intensive. ${ }^{13}$ exigua: synonym of parvus. ${ }^{14}$ angustiīs viärum: by narrowing the strects. 15 contemptionem: English derivative? ${ }^{16}$ quō: interrogative.

Explain the derivation of explōrātōrēs, multitūdinem, celeritāte. What is the stem of speculatoniribus, and what is its meaning? 


\section{EXERCISE XCII}

Grammar: A. 423, I; 507, 3. B. $230 ; 338,4, b ; 339$, I. G. 393: 433. H. 486; 631 .

Inflection: recipiō; equester; uterque.

Order of words: prepositional phrases usually limit a word which follows them.

\section{BOTII ARMIES AVOID A DECISIVE BATTLE}

Eō diē parvulīs ${ }^{1}$ equestribus proeliis ad aquam factīs utrīque sēsē suō locōㄹ continent, — Galli, ${ }^{3}$ quod ampliōrēs cōpiās, quae nōndum convēnerant, exspectābant; Caesar, sī forte timōris simulātiōne hostīs in suum locum èlicere posset, ut citrā vallem prō castrīs

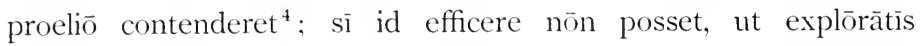
itineribus minōre cum perīculō vallem rīvumque trānsīret. Prīmā lūce hostium equitātus ad castra accēdit proeliumque cum nostrīs equitibus committit. Caesar cōnsultō equitēs cēdere sēque in castra recipere iubet; simul ex omnibus partibus castra altiōre vāllō mūnīrī portāsque obstruī atque in hìs administrandìs rēbus quam maximē concursārīi ${ }^{5}$ et cum simulātiōne agī timōris iubet.

$$
\text { De Bello Gallico, V, } 50
$$

\section{VOCABULARY}

forte, by chance

èliciō, 3, uī, itus, entice

citrā, this side of

rivus, $\bar{i}, \mathrm{~m}$., stream obstrūo, 3 , strūxī, strūctus, block up

concursō, 1, run to and fro

\section{NOTES}

${ }^{1}$ parvulis : parvus + ulus, little. Compare tantulus. ${ }^{2}$ locō: without in, as often. $\quad{ }^{3}$ Galli : understand sēsē suō locō continent. ${ }^{4}$ contenderet: states the purpose of sēsē suō locō continet understood. ${ }^{5}$ concursārī: impersonal.

()bserve how the phrases in the passage illustrate the rule for the order of words. 


\section{EXERCISE XCIII}

Grammar: A. 401 ; 420, 1, 2. B. 2I 4, I, $b ; 227,2, a, b$. G. 405 ; 410. H. $462: 489,1$.

Inflection: volō; manus: quis.

Order of words: adjectives of quantity usually precede the word which they modify.

AFTER LURING TIIE GAULS ON TO THE ATTACK CASAR PLNISHES TIIEN SOUNDLY

Quibus omnibus rēbus ${ }^{1}$ hostēs invìtātī côpiàs trādūcunt aciemque inìquō ${ }^{2}$ locō cōnstituunt, nostris vērō etiam dē vāllō dēductìs propius accēdunt et tēla intrā mūnitiōnem ex omnibus partibus coniciunt, praecōnibusque circummissīs ${ }^{3}$ prōnūntiārī iubent, seu quis Gallus seu Rōmānus velit ante hōram tertiam ad sē trānsīe, sine perīculō licēre; post id tempus nōn fore potestātem. ${ }^{*}$ Ac sīc nostrōs contempsērunt ut obstrūctīs ${ }^{5}$ in speciem ${ }^{6}$ portīs singulis ōrdinibus caespitum, quod eā nōn posse intrōrumpere vidēbantur, aliī vāllum manū scindere, aliī fossās complēre inciperent. 'Tum Caesar omnibus portīs ēruptiōne factā equitātūque ēmissōō celeriter hostīs in fugam dat, sīc utī omnīnō pugnandī causā resisteret nēmō, magnumque ex iīs numerum occidit atque omnīs armīs exuit.

$$
\text { De Bello Gallico, } \mathrm{V}, 5^{\mathrm{I}}
$$

\section{VOCABULARY}

praecō, ōnis, m., herald contemnō, 3, tempsī, temptus, despise caespes, itis, m., sod intrōrumpō, 3, rūpī, ruptus, break into

scindō, 3. scidì, scissus, tear dotin exuō, 3 , ūi, ùtus, strip

\section{NOTES}

${ }^{1}$ quibus rēbus: i. e. those mentioned in the preceding chapter. ¿2 iniquōo : in + aequus. ${ }^{3}$ circummissis: composition? ${ }^{4}$ potestātem : fermission. 5 obstrūctis: participle from obstruō. English derivative? ${ }^{6}$ in speciem: for the salee of afpearanie. 7 èmissō: composition? 


\section{EXERCISE XCIV}

Inflection: vereor: diēs.

Order of words: in a phrase or sentence the emphatic word usually stands first.

\section{CAEAR PRAISES CICERO FOR IIIS BRAIE DEFENSE}

Longius prōsequī veritus, ${ }^{1}$ quod silvae palūdēsque intercēdēbant, omnibus suīs incolumibus eōdem diē ad Cicerōnem pervenit. İnstitūtās turrìs, testūdinēs, mūnitiōnēsque hostium admìrātur ; prōductā legiōne cognōscit nōn decimum quemque ${ }^{2}$ esse reliquum mìlitem sine vulnere; ex hïs omnibus iūdicat rēbus quantō cum perīculō et quantā virtūte rēs sint administrātae. Cicerōnem prō cius meritō legiōnemque conlaudat ; centuriōnēs singillātim tribūnōsque mïlitum appellat, quōrum ēgregiam fuisse virtūtem testimōniō Cicerōnis cognōyerat. Dē cāsū Sabīnī et Cottae $^{3}$ certius ex captīvīs cognōscit. Posterō diē cōntiōne habitā rem gestam prōpōnit, mîlitēs cōnsōlātur et cōnfïrmat. Interim ad Labiēnum ${ }^{*}$ per Rēmōs incrēdibilī celeritāte dē victōriā Caesaris fāma perfertur, ut, cum ${ }^{5}$ ab hỉbernīs Cicerōnis mìlia passuum abesset circiter sexāgintā eōque post hōram nōnam diēì Caesar pervēnisset, ante mediam noctem ad portās castrōrum clāmor orerētur, quō clāmōre significātiō ${ }^{6}$ victōriae grātulātiōque ${ }^{\bar{T}}$ ab Rēmis Labiēnō fieret. - I)E Bello Gallico, V, 52

\section{VOCABULARY}

conlaudō, I, praise highly

cōntiō, ōnis, f., assembly

singillātim, one at a time

testimōnium, testimōnī, n.. cridence cōnsōlor, I, speak kindly to fāma, ae, f., report

\section{NOTES}

\footnotetext{
1 veritus: i.e. C’asar. 2 decimum quemque : onc in ton.
}

3 Sabini et Cottae: treacherously killed by Ambiorix, after their forces had been ambushed. ${ }^{4}$ Labiēnum: he was wintering among the Remi. ${ }^{5}$ cum: considering the short time between hōram nōnam and mediam noctem and the long distance traversed, what must cum mean? ${ }^{6}$ significātiō; signum + faciō + tiō. $\quad{ }^{7}$ grātulātiō: from grātulor, congratulate: 


\section{EXERCISE XCV}

Inflection: maneō; initium.

Order of words: when a noun is modified by an adjective and a genitive, the order often is : adjective, genitive, noun - the particular arrangement depending on emphasis.

THE WIDELY FELT DESIRE AMONG TIE GAULS FOR A REVOLT KEEPS CESAR UNEASY

Hāe fāmā ${ }^{1}$ ad Trēverōs perlātā Indūtiomārus, quī posterō diē castra Labiēnî oppugnāre dēcrēverat, ${ }^{2}$ noctū profugit cōpiāsque omnīs in Trēverōs redūcit. Caesar Fabium ${ }^{3}$ cum suā legiōne remittit in hïberna, ipse cum tribus legiōnibus circum Samarobrīvam ${ }^{4}$ trīnīs ${ }^{5}$ hībernīs hiemāre cōnstituit; et quod tantī mōtūs Galliae exstiterant, tōtam hiemem ipse ad exercitum manēre dēcrēvit. Nam illō incommodō ${ }^{6}$ dē Sabinì morte perlātō omnēs ferē Galliae cìvitātēs dē bellō cōnsultābant, nūntiōs lēgātiōnēsque in omnīs partīs dỉmittēbant, et quid reliquī cönsilī caperent atque unde initium bellī fieret explōrābant, ${ }^{7}$ nocturnaque ${ }^{8}$ in locīs dēsertīs concilia habēbant. Neque ūllum ferē tōtīus hiemis tempus sine sollicitūdine Caesaris intercessit, quīn ${ }^{9}$ aliquem dē cōnsilīis ac mōtū Gallōrum nūntium acciperet. In hỉs ab Lūciō Rōsciō, quem legiōnì tertiae decimae praefēcerat, certior factus est magnās Gallōrum cōpiās eārum cìvitātum quae Aremoricae appellantur oppugnandī suì causā convēnisse, neque longius mìlibus passuum octō ab hibernīs suīs āfuisse, sed nūntiō adlātō dē victōriā Caesaris discessisse, adēo ut fugae similis ${ }^{10}$ discessus ${ }^{11}$ vidērētur. At Caesar prīncipibus cuiusque cìvitātis ad sē ēvocātīs aliōs territandō, ${ }^{12}$ cum sē scìre quae fierent dēnūntiāret, ${ }^{13}$ aliōs cohortandō magnam partem Galliae in officiō tenuit. - De Bello Gallico, V, 53, $5+$

\section{VOCABULARY}

exsistō, 3, stitī, __, arise

cōnsultō, I, deliberate earnestly sollicitūdō, inis, f., anxiety adeō, to such a degreet, so 


\section{NOTES}

1 fāmā: i.e. about Caesar's success. $\quad$ 2 dēcrēverat: synonym of cōnstituō. ${ }^{3}$ Fabium: in charge of the winter quarters among the Morini. ${ }^{4}$ Samarobrivam: a town of the Ambiani. ${ }^{5}$ trinis : used for tribus with hibernis, a noun used only in the plural. $\quad{ }^{6}$ incommodō: in + commodum. $\quad{ }^{7}$ explōrābant: compare with the noun explōrātor. $\quad{ }^{8}$ nocturna : nox + urnus, a time suffix. ${ }^{9}$ quin: without. ${ }^{10}$ similis: English derivative? 11 discessus : noun from discēdō. 12 territandō: by' frishthtenings. 13 dēnūntiāret: composition?

Observè the force of the prefix in perlātā, redūcit, exstiterant, dīmittēbant, praefēcerat, āfuisse.

With the exception of the Aedui and the Remi, whom Cæasar had always especially honored, there is hardly a state that he does not suspect of considering a revolt.

\section{EXERCISE XCVI}

Order of words: in general a phrase or limiting expression is more likely to limit or depend on a word closely following it than on one that has gone before. This is because the limiting word is usually the emphatic part of the phrase.

INIUTIOMARLS TRIES TO ROUSE TIE GERMANS AND

THE GAULS

Trēverī vērōo atque Indūtiomārus tōtīus hiemis nūllum tempus intermisērunt quīn ${ }^{1}$ trāns Rhēnum lēgātōs mitterent, cīvitātēs sollicitārent, pecūniās pollicērentur, magnā parte exercitūs nostrī interfectā multō minörem superesse dīcerent partem. Neque tamen üllì cìvitātī Germānōrum persuādērî potuit ut Rhēnum trānsiret, cum sē bis expertōs dicerent, Ariovistī bellō et 'Tencterōrum trānsitū² ; nōn esse amplius fortūnam temptātūrōs. Hāc spē lāpsus Indūtiomārus nihilō minus cōpiās cōgere, exercēre, ā fīnitimīs equōs parāre, exsulēs damnātōsque tōtā Galliā magnīs praemiīs ad sē allicere coepit. Ac tantam sibi iam hìs rēbus in Galliā auctōritātem comparāverat ut undique ad eum lēgātiōnēs concurrerent, grātiam ${ }^{3}$ atque amīcitiam pūblicē prīvātimque ${ }^{4}$ peterent. - DE Bello Gallico, V, 55 


\section{VOCABULARY}

sollicitō, I, stir up

pecūnia, ae, f., money

lābor, 3, lāpsus, slip

exerceō, 2 , uī, itus, train exsul, ulis, m.,f., exile

damnō, I, convict

alliciō, 3, lexī, lectus, attract

\section{NOTES}

${ }^{1}$ quīn: without. $\quad 2$ trānsitū: a verbal noun from trānseō. $\quad{ }^{3}$ grātiam: i.e. of Indutiomarus. $\quad{ }^{4}$ prīvātim: compare with nōminātim, singillātim.

Select from the passage words that by their position illustrate the rule for the order of words.

\section{EXERCISE XCVII}

Order of words: an adverb usually precedes the word which it modifies.

SEVERAL STATES REBEL AGAINST THE ROMANS

Interfectō Indūtiomārō, ${ }^{1}$ ut docuimus, ad eius propinquōs à Trêverìs imperium dēfertur. Illī finnitimōs Germānōs sollicitāre et pecūniam pollicērì nōn dēsistunt. Cum à proximìs impetrāre nōn possent, ulteriōrēs temptant. Inventīs ${ }^{2}$ nōn nūllis civitātibus iūre iūrandō inter sē cōnfürmant obsidibusque dē pecūniā cavent ${ }^{3}$; Ambiorigem sibi societāte et foedere adiungunt. ${ }^{+}$Quibus rēbus cognitīs Caesar, cum undique bellum parārī vidēret, Nerviōs, Aduatucōs, Menapiōs adiūnctīs Cisrhēnānīs ${ }^{5}$ omnibus Germānīs esse in armīs, Senonēs ad imperātum nōn venīre et cum Carnutibus fīnitimisque cīvitātibus cōnsilia commūnicāre, ${ }^{6}$ ā Trêverīs Germānōs crēbrīs lēgātiōnibus sollicitārī, mātūrius sibi dē bellō cōgitandum putāvit. - DE Bello Gallico, VI, 2

\section{VOCABULARY}

sollicitō, I, stir up

pecūnia, ae, f., money'

societās, ātis, f., alliance foedus, eris, n., treaty

cōgitō, I, consider 


\section{NOTES}

${ }^{1}$ Indūtiomārō: he was killed by the soldiers of Labienus, who all aimed their weapons at him when he approached the camp with his cavalry in a foolhardy way. Labienus had offered great rewards to those who should kill Indutiomarus and thus end the uprising. 2 inventis: composition? 3 obsidibusque ... cavent: giz'e hostages as security for the money. ${ }_{4}^{4}$ adiungunt: composition? ${ }^{5}$ Cisrhēnānis: cis, on this side of, + Rhēnus + ānus, pertaining to. $\quad{ }^{6}$ commūnicäre: English derivative?

Think of English words from dēfertur, pecūniam, ulteriōrēs, inventīs, foedere, and observe how the meaning of the Latin word helps to make plain the meaning of the English.

\section{EXERCISE XCVIII}

Order of words: the modifiers of the parts of an ablative absolute often stand between the words that compose it, the degree of emphasis of each word determining its position.

\section{AFTER A RAID AMONG TIE NERVII C.ESAR ENTERS} THE TERRITORY OF THE SENONES

Itaque nōndum hieme cōnfectā, proximīs quattuor coāctīs legiōnibus, dē imprōvisō in finis Nerviōrum contendit, et, priusquam illī aut convenīe aut profugere possent, magnō pecoris atque hominum numerō captō atque eā praedā militibus concessā vāstātīsque agrīs, in dēelitiōnem venīre atque obsidēs sibi dare coēgit. Eōo celeriter cōnfectō negōtiō rūrsus in hīberna legiōnēs redūxit. Conciliō Galliae prīmō vēre, ut $^{1}$ instituerat, indictō, cum reliquī praeter Senonēs, Carnutēs, 'Trēverōsque vēnissent, initium bellī ac dēfectiōnis hoc ${ }^{2}$ esse arbitrătus, ${ }^{3}$ ut omnia postpōnere vidērētur, concilium Lutetiam ${ }^{4}$ Parīsiōrum trānsfert. Cōnfīnēs ${ }^{5}$ erant hì Senonibus cìvitātemque patrum memoriā coniūnxerant, sed ab hōc cōnsiliō āfuisse exīstimābantur. Hāc rêe ${ }^{6}$ prōo suggestū prōnūntiātā eōdem diē cum legiōnibus in Senonēs proficiscitur magnisque itineribus eō pervenit. - De Bello Gallico, VI, 3 


\section{VOCABULARY}

vēr, vēris, n., springs

indīcō, 3 , dīxī, dictus, appoint

postpōnō, 3, posuī, positus, dēfectiō, ōnis, f., recolt

deem less important

suggestus, ūs, m., tribunal

\section{NOTES}

1 ut: notice the mood following. 2 hoc: refers to praeter... Trēverōs, i. e. their absence. $\quad{ }^{3}$ arbitrātus: synonym of exīstimō. $\quad{ }^{4}$ Lutetiam: the modern Paris. $\quad{ }^{5}$ cōnfīnēs: synonym of finitimus. $\quad{ }^{6}$ hāc rē: i.e. ab... āfuisse.

\section{EXERCISE XCIX}

Order of words: in any phrase the determining or emphatic word comes first.

\section{CASAR'S ARRIVAL DISCONCERTS TIIE SENONES AND}

THE CARNUTES, AND THEY SUBMIT

Cognitō eius ${ }^{1}$ adventū Accō, ${ }^{2}$ quī prīnceps eius cōnsilī ${ }^{3}$ fuerat, iubet in oppida multitūdinem convenīre. C'ōnantibus, ${ }^{4}$ priusquam id efficī posset, adesse Rōmānōs nūntiātur. Necessāriō sententiā dēsistunt lēgātōsque dēprecandỉ causā ad Caesarem mittunt ; adeunt per Aeduōs, quōrum antiquitus ${ }^{5}$ erat in fidē civitās. Libenter Caesar petentibus Aeduīs dat veniam excūsātiōnemque ${ }^{6}$ accipit, quod aestīvum tempus īnstantis ${ }^{7}$ bellī, nōn quaestiōnis ${ }^{8}$ esse arbitrābātur. ${ }^{9}$ Obsidibus imperātīs centum hōs Aeduīs custōdiendōs trādit. Eṑdem Carnutēs lēgătōs obsidēsque mittunt ūsī dēprecātōribus ${ }^{10}$ Rēmīs, quōrum erant in clientēlā; eadem ferunt respōnsa. Peragit concilium Caesar equitēsque imperat cìvitātibus.

$$
\text { De Belio Gallico, Vi, } 4
$$

\section{VOCABULARY}

adsum, esse, fui, __, be fresent dēprecor, 1, beg off

libenter, willingly

venia, ae, f., pardon! aestivus, a, um, of summer. summer custōdiō, +, ivin, itus, watch clientēla, ae, f., protection 


\section{NOTES}

1 eius: i.e. Cæsar's. ${ }^{2}$ Accō: a leader of the Senones. ${ }^{3}$ cōnsilī: i.e. for a revolt. $\quad{ }^{4}$ cōnantibus: i.e. in oppida convenire. $\quad{ }^{5}$ antíquitus: adverb from antiquus, which is synonymous with vetus. ${ }^{6}$ excūsātiōnem: excūsō + tiō. ${ }^{7}$ instantis: impending, i.e. the one with the Treveri. ${ }^{8}$ quaestiōnis: quaerō + tiō. $\quad{ }^{9}$ arbitrābātur: synonym of existimōo. $\quad{ }^{10}$ dēprecātōribus : derivation?

Under the leadership of Vercingetorix, the most heroic figure in the struggle of Gaul against the Romans, a general uprising occurs. After much desperate fighting, sacking of towns, and laying waste of fields, the advaniage being on the side of the Romans, Vercingetorix makes a last stand in Alesia, now called Alise-Sainte-Reine, a town in central Gaul. 


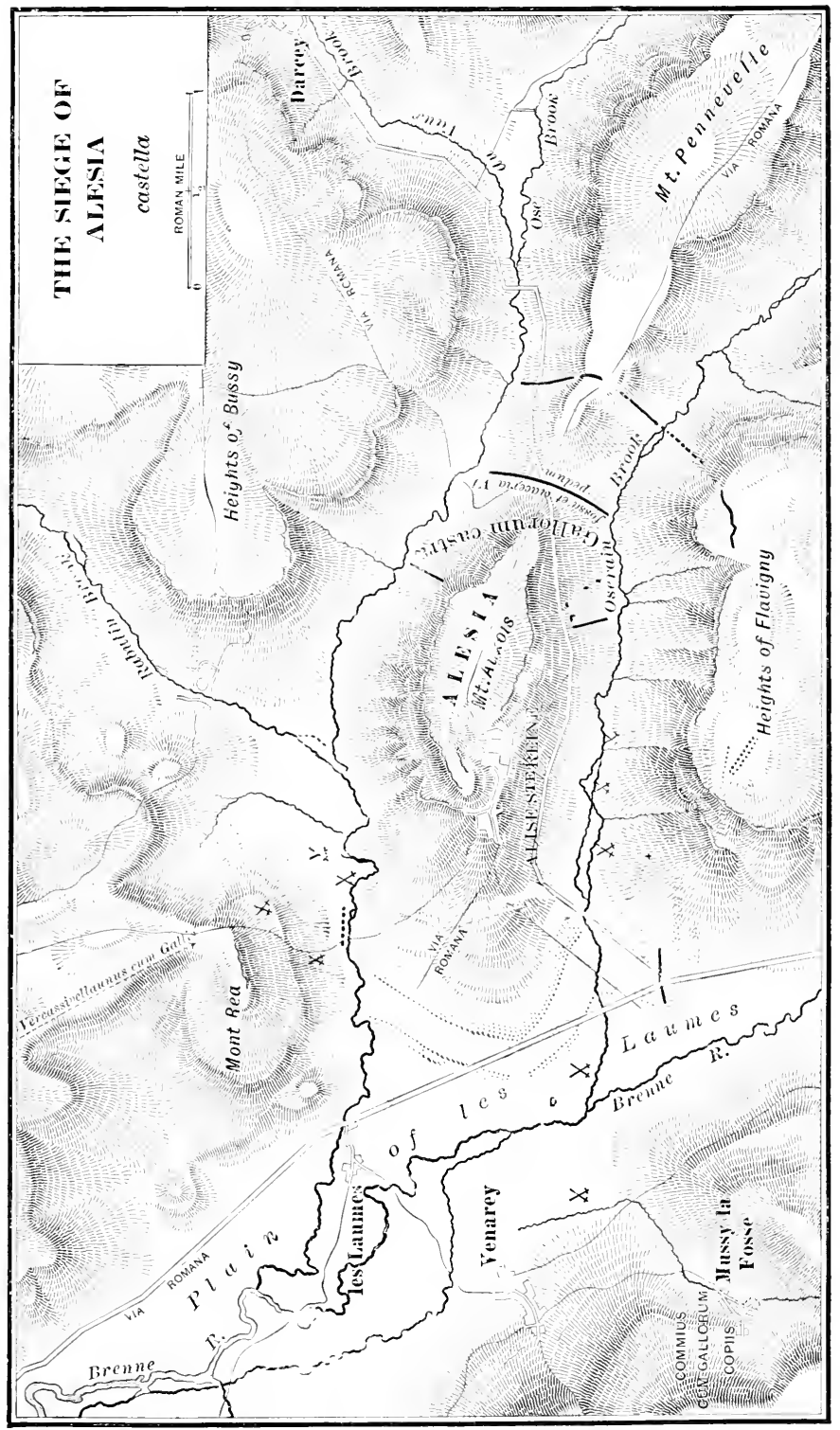





\section{DE BELLO GALLICO, VII}

VERCINGETORIX WITHDRAWS INTO ALESIA, CASAR AT HIS HEELS

68. Fugātō omnī equitātū Vercingetorix côpiās suās, ut ${ }^{1}$ prō castrīs conlocāverat, redūxit prōtinusque ${ }^{2}$ Alesiam, quod ${ }^{3}$ est oppidum Mandubiōrum, iter facere coepit, celeriterque impedimenta ex castrīs èdūcī et sē subsequī iussit. Caesar impedīmentīs in proximum collem ductīs, duābus legiōnibus praesidiō relictīs, secūtus hostīs quantum ${ }^{4}$ diēì tempus est passum, circiter tribus milibus ex novissimō agmine interfectīs, alterō diē ad Alesiam castra fēcit. Perspectō urbis sitū perterritīsque hostibus, quod equitātū, ${ }^{\circ}$ quā maximē parte exercitūs cōnfïdēbant, erant pulsī, adhortātus ${ }^{6}$ ad labōrem mīlitēs Alesiam circumvāllāre īnstituit.

THE NATLRAL SURROLNDINGS OF ALESIA

69. Ipsum erat oppidum in colle summō, admodum èditö locō, ut nisī̄ obsidiōne expugnārī nōn posse vidērētur; cuius collis rādícēs duo duābus ex partibus flūmina subluēbant. Ante oppidum

fugō, г, put to flight

situs, üs, m., situation admodum, a'ery

subluō, 3 , - , lūtum, wash circumvāllō, I, build intrenchments around

1 ut: notice the mood of conlocāverat. $\quad{ }^{2}$ prōtinus : synnonym of statim. ${ }^{3}$ quod: takes the gender of oppidum. $\quad{ }^{4}$ quantum: as far as. $\quad{ }^{5}$ equitātū : ablative of specification, but translate as subject of the verb which it limits. ${ }^{6}$ adhortātus: = hortātus. $\quad{ }^{7}$ nisi: with obsidiōne.

Observe that the words prōtinus, celeriter, proximum, and quantum ... passum, and the short, crisp phrases make vivid the haste of this flight and the fierceness of the pursuit. 
plānitiēs circiter mìlia passuum tria in longitūdinem patēbat; reliquīs ex omnibus partibus collēs mediocrī interiectōo ${ }^{1}$ spatiō parī altitūdinis fastīgiō oppidum cingēbant. Sub mūrō, quae pars collis ad orientem sōlem spectābat, hunc omnem locum cōpiae Gallōrum complēverant fossamque et māceriam² in altitūdinem sex pedum praedūxerant. $^{3}$ Eius mūnitiōnis quae ab Rōmānīs instituēbātur circuitus ūndecim mīlia passuum tenēbat. Castra opportūnīs locīs erant posita octōna castellaque vīgintī tria facta, quibus in castellīs interdiū statiōnēs pōnēbantur, nē qua ${ }^{4}$ subitō ēruptiō fieret; haec eadem noctū excubitōribus ac fïrmis praesidīs tenēbantur.

A CAVALRY BATTLE IS FOUGHT, IN WHICH CASAR'S GERMAN TROOPS KILL MANY OF THE GAULS

70. Opere ${ }^{5}$ institūtō fit equestre proelium in eā plānitiē quam intermissam collibus tria mìlia passuum in longitūdinem ${ }^{6}$ patēre suprā dēmōnstrāvimus. Summā vĩ ab utrisque contenditur. ${ }^{7}$ Labōrantibus nostrīs Caesar Germānōs submittit legiōnēsque prō castrīs cōnstituit, nē qua subitō irruptiō ab hostium peditātū ${ }^{8}$ fiat. Praesidiō legiōnum additō ${ }^{9}$ nostrīs animus augētur; hostēs in fugam coniectī sē ipsì multitūdine ${ }^{10}$ impediunt atque angustiōribus portīs relictīs coartantur. Germānī ācrius ūsque ad mūnitiōnēs sequuntur. Fit magna caedēs; nōn nūlli relictìs equìs fossam trānsīre et māceriam trānscendere cōnantur. Paulum legiōnēs Caesar quās prō vāllō

plānitiēs, è̄i, f., flain

mediocris, e, moderate

fastīgium, fastīgī, n., degree

interdiū, by $d a y$

excubitor, ōris, m., watihman irruptiō, ōnis, f., ina'asion coartō, r, press together

ùsque, all the way caedēs, is, f., slaughter
1 interiectō : composition? dūxerant : composition? compassing fortifications. impersonal. equitēs.
${ }^{8}$ peditātū: synonym of peditēs. Compare equitātus and ${ }^{9}$ additō: participle. English derivative?. ${ }^{10}$ multitūdine: states the cause of impediunt. 
cōnstituerat prōmovērī iubet. Nōn minus quī intrā mūnìtiōnēs erant Gallī perturbantur, venīin̄i ${ }^{1}$ ad sē cōnfestim exīstimantēs ad arma conclāmant; nōn nūllī perterritī in oppidum irrumpunt." Vercingetorīx iubet portās claudì, nē castra nūdentur. Multīs interfectīs, complūribus equīs captĩs Germānì sēsē recipiunt.

\section{VERCINGETORIX SENDS AWAY ALL TIIE CAVALRY, URGING THEM TO RAISE FORCES FOR THE RELIEF OF ALESIA}

71. Vercingetorīx, priusquam mūnītiōnēs ab Rōmānīs perficiantur, cōnsilium capit omnem ab sē equitātum noctū dīmittere. Discēdentibus $^{3}$ mandat ut suam quisque eōrum cīvitātem adeat omnīsque quī per aetātem arma ferre possint ad bellum cōgant; sua in ${ }^{4}$ illôs merita prōpōnit obtestāturque ut suac salūtis ratiōnem ${ }^{j}$ habeant, neu ${ }^{6}$ sē optimē dē commūnī lỉbertāte meritum ${ }^{7}$ hostibus in cruciātum dēdant. Quod sī indīligentiōrēs fuerint, mīlia hominum dēlēcta octōgintā ūnā sēcum interitūra dēmōnstrat. Ratiōne ${ }^{8}$ initā frūmentum sē exigue ${ }^{9}$ diērum trīgintā habēre, sed paulō etiam longius tolerărīi ${ }^{10}$ posse parcendō. Hīs datīs mandātīs ${ }^{11}$ quā erat nostrum opus intermissum secundā vigiliā silentiōôn equitātum dīmittit. Frümentum omne ad sē referrì iubet; capitis poenam ī̄s quī nōn pāruerint cōnstituit; pecus, cuius magna erat cōpia à

claudō, 3, clausī, clausus, shut

aetās, ātis, f., age

obtestor, I, call to witness

indīligēns, entis, careless intereō, 4 , iī, itum, perish

parcō, 3. pepercī, parsum, spare

poena, ae, f., funishment

pāreō, 2, uī, —, olecy

1 veniri: the enemy nere coming. Impersonal. 2 irrumpunt: from the root of this verb is derived irruptio. " discēdentibus: understand iīs. ${ }^{4}$ in: towird. ${ }^{5}$ ratiōnem: regard. ${ }^{6}$ neu : and not. ${ }^{7}$ meritum: participle; translate by a relative clause. ${ }^{8}$ ratione: reckoning. This begins an indirect statement, depending on the verb dēmōnstrat. ${ }^{9}$ exiguē: synonym of vix. $\quad{ }^{10}$ tolerārī: nearly $=$ ferō; impersonal. ${ }^{11}$ mandātis : noun. 12 silentiō: noun. English derivative? 
Mandubiīs compulsa, virītim ${ }^{1}$ distribuit; frūmentum parcē $^{2}$ et paulātim mētîrī instituit ; cōpiās omnìs quās prō oppidō conlocãverat in oppidum recipit. Hīs ratiōnibus auxilia Galliae exspectāre et bellum administrāre parat.

\section{THE GAULS RAISE A GREAT ARMY ANI PROCEEI) TO}

\section{ALESIA}

76. Huius operā Commīi, ${ }^{3}$ ut antea ${ }^{4}$ dēmōnstrāvimus, fidè $\bar{l}^{5}{ }^{5}$ atque ùtilī superiōribus annīs erat ūsus in Britanniā Caesar; prō quibus meritīs civitātem eius immūnem esse iusserat, iūra lēgēsque reddiderat, atque ipsī Morinōs attribuerat. Tanta tamen ūniversae ${ }^{6}$ Galliae cōnsēnsiō ${ }^{7}$ fuit lībertātis vindicandae ${ }^{8}$ et prīstinae bellī laudis recuperandae ut neque beneficīs neque amīcitiae memoriā movērētur, omnēsque et animō et opibus in id bellum incumberent. Coāctīs equitum mîlibus octō et peditum circiter ducentis quīnquāgintā, haec in Aeduōrum fīnibus recēnsēbantur numerusque inibātur, praefectī cōnstituēbantur; Commiō Atrebātī, Viriclomārō et Eporēdorīgī Aeduīs, Vercassivellaunō Arvernō,

mētior, t, mënsus, mèsurè out immūnis, e, untared

lēx, lēgis, f., law

attribuō, 3, uī, ūtus, assign

laus, laudis, f., glory

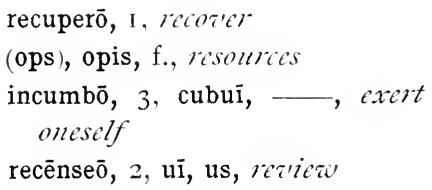

2 parcē : adverb; compare parcō. $\quad{ }^{3}$ Commì : he was sent by Cæsar into Britain to persuade the states there to submit to the Roman rule. $\quad{ }^{*}$ anteā: adverb, synonym of ante. ${ }^{5}$ fidèlī : fidès + èlis, fertaining to. ${ }^{6}$ üniversae: English derivative? Synonym of tōtus. ${ }^{7}$ cōnsēnsiō : con + sentiō + tiō. ${ }^{8}$ vindicandae: synonym of dēfendō.

In order to bring about the surrender of Alesia and to prevent other forces being added to those in the town, Cæsar constructed an elaborate system of fortifications, extending fourteen miles. These consisted of deep trenches, high walls, and several rows of sharpened stakes, besides others set up at the bottom of pits, which were covered with branches to conceal them. 
cōnsobrīnō Vercingetorīgis, summa ${ }^{1}$ imperī trāditur. His ${ }^{2}$ dēlêctî̀ $^{3}$ ex civitātibus attribuuntur, quōrum cōnsiliō bellum administrārētur. Omnēs alacrēs et fīdūiciae ${ }^{4}$ plēnī $^{5}$ ad Alesiam proficìscuntur, neque erat omnium quisquam quĩ aspectum ${ }^{6}$ modo tantae multitūdinis sustinērī posse arbitrārētur, praesertim ancipitī ${ }^{\top}$ proeliō, cum ex oppidō ēruptiōne pugnārētur, forīs tantae cōpiae equitātūs peditātūsque cernerentur.

TIIE GAULS IN ALESIA IEBATE TIIEIR FUTURE ACTION. CRITOGNATLS BEGINS HIS SPEECII

77. At ì quì Alesiae obsidēbantur, praeteritā diè quā auxilia suōrum exspectāverant, cōnsümptō omnī frūmentō, inscī̄ ${ }^{8}$ quid in Aeduīs gererētur, conciliō coāctō dē exitū suārum fortūnārum cōnsultābant. ${ }^{9}$ Ac variīs dictīs sententī̄s, quārum pars dēditiōnem, pars, dum vìrēs suppeterent, ēruptiōnem cēnsēbat, nōn praetereunda ōrātiō Critognātī vidētur propter eius ${ }^{10}$ singulārem et nefāriam crūdēlitātem. Hīc summō in Arvernìs ortus locō et magnae habitus auctōritātis, ${ }^{11}$ " Nihil," inquit, ${ }^{12}$ " dē eōrum sententiā dictūrus sum quī turpissimam servitūtem dēditiōnis nōmine appellant, neque hōs habendōs ${ }^{13}$ cìvium locō neque ad concilium adhibendōs cēnseō. Cum his mihi rēs ${ }^{1+}$ est quī èruptiōnem probant; quōrum in cōnsiliō

cōnsobrīnus, $\overline{1}, \mathrm{~m} .$, first cousin forīs, outside

obsideō, 2, sēdì, sessus, besiege praeterē̄, 4 , iī, itus, pass oz'er exitus, ùs, m., outcome suppetō, 3, petivì, petìtus, hold out cēnseō, 2, ui, us, profosé, consider nefärius, a, um, wicked crūdēlitās, ātis, f., cruelty turpis, e, shameful

${ }^{1}$ summa: noun. $\quad{ }^{2}$ hìs : i.e. those just mentioned. $\quad{ }^{3}$ dēlēctī: understand hominēs. $\quad{ }^{4}$ fĩdūciae: synonym of fidēs. $\quad{ }^{5}$ plēnī: synonym of complētus. $\quad{ }^{6}$ aspectum : synonym of cōnspectus. $\quad{ }^{7}$ ancipitī : in front and rear. 8 insciī: in + sciō. $\quad{ }^{9}$ cōnsultābant: English derivative? ${ }^{10}$ eius: i. e. ōrātiōnis. $\quad 11$ auctōritātis : a quality of hīc. 12 inquit : defective verb, synonym of dīcō. $\quad{ }^{13}$ habendōs : understand esse. Compare this form with dictūrus sum above. Habē̄, consider. ${ }^{11}$ rēs: husincss.

Note the size and the spirit of the army which came to free Alesia. 
omnium vestrum cōnsēns $\bar{u}^{1}$ prīstinae residēre virtūtis memoria vidētur. Animī est ista mollitia, nōn virtūs, paulisper inopiam ferre nōn posse..$^{2}$ ( uì $^{3}$ sē ultrō mortī offerant facilius reperiuntur quam qui dolōrem ${ }^{4}$ pátienter ${ }^{j}$ ferant."

CRITOGNATLS APPEALS TO HIS HEARERS NOT TO LOSE FAITI IN THE GALLS WHO IHAVE NOT YET BEEN ABLE TO REACH TIEN

77. "Atque ego hanc sententiam probārem ${ }^{6}$ (tantum apud mē dignitās potest), sī nūllam praeterquam ${ }^{7}$ vìtae nostrae iactūram fierī vidērem; sed in cōnsiliō capiendō omnem Galliam respiciāmus, ${ }^{8}$ quam ad nostrum auxilium concitāinimus. Quid, ${ }^{9}$ hominum mīlibus octōgintā ūnō locō interfectīs, propinquīs ${ }^{10}$ cōnsanguineìsque nostrīs animī fore exīstimātis, sī paene in ipsīs cadāveribus proeliō dēcertäre cōgentur? Nōlite ${ }^{11}$ hôs vestrō auxiliō exspoliāre, quī vestrae salūtis causā suum perīculum neglēxērunt, nec stultitiā ac temeritāte vestrā aut animī imbēcillitāte omnem Galliam prōsternere et perpetuae servitūiti subicere. An,$^{12}$ quod ad diem nōn vēnērunt, dē eōrum fidè cōnstantiāque dubitātis? Quid ergōo ? Rōmānōs in illīs

resideō, 2, sēđi, __ _ linger

mollitia, ae, f., a'caliness

dignitās, ātis, f., honor

vita, ae, f., life

iactūra, ae, f.. loss

concitō, 1, stir up

cadāver, eris, n., dead body' exspoliō, I, deprize

stultitia, ae, f., folly

temeritās, ātis, f., rashness

imbēcillitās, àtis, f., weakness

prōsternō, 3, strāvī, strātus, min ergō, then, therefore

${ }^{1}$ cōnsēnsū : con + sentiō + tus. $\quad{ }^{2}$ paulisper . . . posse : used as a noun in apposition with ista. $\quad{ }^{3}$ qui : the antecedent is the subject of reperiuntur. ${ }^{4}$ dolōrem: dole $\overline{0}+$ or, act of. $\quad{ }^{5}$ patienter: adverb from the present participle of patior. English derivative? $\quad{ }^{6}$ probārem: should affrow'e. $\quad{ }^{7}$ praeterquam : adverb; compare with praeter. ${ }^{8}$ respiciāmus: introduce the translation by let. ${ }^{9}$ quid: with animi. ${ }^{10}$ propinquis, etc.: dative of the possessor. In translating, make this the subject of the clause, and render fore by the appropriate tense of hav' $\quad 11$ nōite: do not. 12 an: the sign of a question, introducing the clause beginning with dê. Translate by or. 
ulteriōribus mūnītiōnibus animine ${ }^{1}$ causā cotīdiē exercērî putātis ? Sì illōrum nūntī̄s cōnfīrmārī nōn potestis omnī aditū praesaeptō, hīs ūtiminì testibus appropinquāre eōrum adventum"; cuius reì timōre exterritīi ${ }^{3}$ diem noctemque in opere versantur."

\section{CRITOGNATUS PROPOSES A BARBAROUS PLAN FOR RESISTING THE ROMANS}

77. "Quid ergōo meì cōnsilī ${ }^{*}$ est? Facere quod nostrī maiōrēes nēquāquam parī bellō Cimbrōrum Teutonumque fēcērunt; quī in oppida compulsī ac similī inopiā subāctī eōrum corporibus ${ }^{5}$ quī aetāte ad bellum inūtilēs ${ }^{6}$ vidēbantur vìtam tolerāvērunt ${ }^{7}$ neque sē hostibus trādidērunt. Cuius reī sì exemplum nōn habērēmus, tamen lỉbertātis causā instituī $^{8}$ et posterīs prōdī ${ }^{9}$ pulcherrimum iūdicārem. Nam quid illī simile bellō fuit? Dēpopulātā ${ }^{10}$ Galliā Cimbrī magnāque illātā calamitāte fīnibus quidem nostrīs aliquandō excessērunt atque aliās terrās petiērunt, iūra, lēgēs, agrōs, lībertātem nōbìs relīquērunt. Rōmānī vērō quid petunt aliud aut quid volunt, nisi invidiā adductī, quōs ${ }^{11}$ fämā nōbilīs potentīsque bellō cognōvērunt, hōrum in agrīs cīvitātibusque cōnsīdere atque hīs aeternam ${ }^{12}$ iniungere ${ }^{13}$ servitūtem ? Neque enim umquam aliā condiciōne bella gessērunt. Quod sī ea

exerceō, 2 , uî, itus, occupy

praesaepiō, 4, saepsī, saeptus,

block

testis, is, m., f., witness

ergō, then, therefore

nēquāquam, by no means

similis, e, like

subiḡo, 3, ègī, āctus, driz'e aetās, ātis, f., age vita, ae, f., life exemplum, i, n., precedent aliquandō, at length lēx, lēgis, f., law invidia, ae, f., enc'y fāma, ae, f., reputation umquam, eqer

${ }^{1}$ animine: note the question sign. quāre. $\quad{ }^{3}$ exterritī : synonym of perterrití. ${ }^{4}$ cōnsilì : predicate genitive.

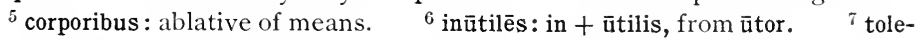
rāvērunt: synonym of ferō. $\quad{ }^{8}$ instituī : understand id as subject, referring to exemplum. $\quad{ }^{9}$ prōdì: synonym of trādō. populor. ${ }^{11}$ quōs: the antecedent is hōrum. perpetuus. 13 iniungere: composition?

1) dēpopulātā: synonym of 12 aeternam: synonym of 
quae in longinquīs nātiōnibus geruntur ignōrātis, respicite fīnitimam Galliam, quae in prōvinciam redācta, iūre et lēgibus commūtātīs, secūribus ${ }^{1}$ subiecta perpetuā premitur servitūte."

THE GAULS SEND OUT FROM ALESIA THOSE USELESS FOR FIGHTING

78. Sententiīs dictīs cōnstituunt ut iì quī valētūdine aut aetāte inūtilēs ${ }^{2}$ sint bellō oppidō excēdant, atque omnia prius ${ }^{3}$ experiantur quam ad Critognātī sententiam dēscendant ${ }^{4}$; illō tamen potius ūtendum ${ }^{5}$ cōnsiliō, sī rēs cōgat atque auxilia morentur, quam aut dēditiōnis aut pācis subeundam condiciōnem. Mandubīi ${ }^{6}{ }^{6}$ qui eōs ${ }^{7}$ oppidō recēperant, cum liberīs atque uxōribus exīre cōguntur. Hì cum ad mūnitiōnēs Rōmānōrum accessissent, flentēs omnibus precibus ōrābant ut sē in servitūtem receptōs cibō iuvārent. At Caesar dispositīs ${ }^{8}$ in vāllō custōdīis recipị ${ }^{9}$ prohibēbat.

\section{THE MAIN FORCES OF THE GAULS REACH ALESIA AND}

ALL PREPARE FOR A SALLY

79. Intereā Commius reliquĩque ducēs quibus summa imperī permissa erat cum omnibus cōpiīs ad Alesiam perveniunt, et colle exteriōre occupātō nōn longius mìlle passibus à nostrīs mūnitiōnibus cōnsīdunt. Posterō diē equitātū ex castrīs èductō omnem eam plānitiem quam in longitūdinem mìlia passuum tria patēre

ignōrō, I, be unacquainted with

commūtō, I, change

valētūdō, inis, f., sickness

aetās, ātis, f., age uxor, öris, f., wife

custōdia, ae, f., guard

plānitiēs, è̄i, f., plain

${ }^{1}$ secūribus: axes, but used as a symbol of Roman authority. 2 inütilēs : in + ūtilis, from ütor. ${ }^{3}$ prius: with quam. ${ }^{4}$ dēscendant: English derivative? 5 ütendum: impersonal ; an indirect statement with esse understood. Make cōnsiliō the subject in the translation. ${ }^{6}$ Mandubii : the tribe in whose territory Alesia was situated. ${ }^{7}$ eōs: the Gauls. ${ }^{8}$ dispositis: composition? ${ }^{9}$ recipi : from being received. 
dēmōnstrāvimus complent, pedestrīsque cōpiās paulum ab eō locō abductās $^{1}$ in locīs superiōribus cōnstituunt. Erat ex oppidō Alesiā dēspectus ${ }^{2}$ in campum. Concurrunt hìs auxilìis vìsīs; fit grātulātiō inter eōs, atque omnium animī ad laetitiam excitantur. ${ }^{3}$ Itaque prōductīs cōpiīs ante oppidum cōnsistunt, et proximam fossam crātibus integint atque aggere explent, ${ }^{\sharp}$ sēque ad ēruptiōnem atque omnīs cāsūs comparant.

\section{AFTER A FIERCE FIGIIT TIIE GAULS RETREAT AND THOSE IN THE TOWN LOSE HOPE}

80. Caesar omnī exercitū ad utramque partem mūnìtiōnum dispositō, ${ }^{\bar{j}}$ ut, sī ūsus veniat, suum quisque locum teneat et nōverit, equitātum ex castrīs êdūiè et proelium committī iubet. Erat ex omnibus castrīs, quae summum undique iugum tenēbant, dēspectus, atque omnēs militēs intentî ${ }^{6}$ pugnae prōventum exspectābant. Gallī inter equitēs rārōs ${ }^{7}$ sagittāriōs expedîtōsque levis armātūrae interiēcerant, ${ }^{8}$ quī suīs cēdentibus auxiliō succurrerent ${ }^{9}$ et nostrōrum equitum impetūs sustinērent. Ab hìs complürēs dē imprōvīsō vulnerātī proeliō excēdēbant. Cum suōs pugnā superiōrēs esse Gallī cōnfīderent et nostrōs multitūdine premī vidērent, ex omnibus partibus et iî quī mūnītiōnibus continēbantur et iī quī ad auxilium convēnerant clāmōre et ululātū suōrum animōs cōnfīrmābant. Quod in cōnspectū omnium rēs gerēbātur neque rēctē aut turpiter

grātulātiō, ōnis, f., rejoicins

laetitia, ae f., gladness

crātēs, ium, f., wickerwork

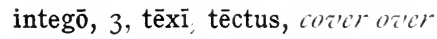

prōventus, ùs, m., outiome sagittārius, sagittārī, m., bowiman armātūra, ae, f., armor ululātus, ùs, m., y'cllings rēctēe, righlltly turpiter, discraciofilly

1 abductās : composition? $\quad{ }^{2}$ dēspectus : dēspiciōo + tus. ${ }^{3}$ excitantur : English derivative? $\quad{ }^{4}$ explent: note the prefix, and compare with compleō. 5 dispositō: composition? ${ }^{6}$ intentī: adjective. English derivative? ${ }^{7}$ rārōs: here and then. ${ }^{8}$ interiēcerant: composition? ${ }^{9}$ succurrerent: sub, "up to. 
factum cēlārī poterat, utrōsque et laudis cupiditās ${ }^{1}$ et timor ignōminiae ad virtūtem excitābat. ${ }^{2}$ Cum a a merīdiē $\bar{B}^{3}$ prope ad sōlis occāsum dubiā ${ }^{4}$ victōriā pugnārētur, Germānī ūnā in parte cōnfertīs turmīs in hostīs impetum fēcērunt eōsque prōpulērunt ${ }^{5}$; quibus in fugam coniectīs sagittārī circumventī interfectīque sunt. Item ex reliquīs partibus nostrī cèdentīs ūsque ad castra însecūtī suĩ colligendī facultātem nōn dedērunt. At ì̄ quī Alesiā prōcessērunt, maestī prope victōriā dēspērātā, ${ }^{6}$ sē in oppidum recēpērunt.

THE GAULS OUTSIDE TIIE TOWN, HELPED BY TIIOSE WITHIN, TRY A NIGHT ATTACK

81. 'T̄nō diē intermissō Gallī atque hōe spatiō ${ }^{7}$ magnō crātium, scālārum, harpagōnum numerō effectō mediā nocte silentiō ex castrīs ēgressī ad campestrīs mūnìtiōnēs accēdunt. Subitō clāmōre sublātō, quā significātiōne ${ }^{8}$ quī $^{9}$ in oppidō obsidēbantur dē suōo adventū cognōscere possent, crātīs prōicere, fundīs, sagittīs, lapidibus nostrōs dē vāllō prōturbảre, reliquaque quae ad oppugnātiōnem pertinent parant administrāre. Eōdem tempore clāmōre exauditōo ${ }^{10}$ dat tubā signum suīs Vercingetorīx atque ex oppidō èdūcit. Nostrī, ut superiōribus diēbus suus cuique erat locus

laus, laudis, f., praise

ignōminia, ae, f., disgrace

turma, ae, f., troop

ùsque, all the way

colligō, 3, lēgī, lēctus, rally

maestus, a, um, sad

crātēs, ium, f., wickerwork scālae, ārum, f., sculing ladders harpagō, ōnis, m., wall hook silentium, silentī, n., silence campester, tris, tre, in the plain obsideō, 2, sēdī, sessus, besiege funda, ae, f., sling prōturbō, I, driz'e off

${ }^{1}$ cupiditās: derivation? 2excitābat: English derivative? '3 merīdiē: medius + diēs. $\quad{ }^{4}$ dubiā: adjective; compare with dubitō. ${ }^{5}$ prōpulērunt: composition? ${ }^{6}$ dēspērātā: composition? ' within which the action of effectō happened. ${ }^{8}$ significātiōne : signum + faciō + tīō. ${ }^{9}$ quī: understand $\mathrm{i} \overline{1}$, subject of possent, as antecedent. ${ }^{10}$ exauditō: composition? 
attribūtus, ad mūnītiōnēs accēdunt; fundīs librīlibus sudibusque, quās in opere disposuerant, ac glandibus Gallōs prōterrent. ${ }^{1}$ P’ōospectū $^{2}$ tenebrīs adēmptō multa utrimque vulnera accipiuntur; complūra tormentīs tēla coniciuntur. At Mārcus Antōnius et Gāius Trebōnius lēgātī, quibus hae partès ad défendendum obvènerant, ${ }^{3}$ quā ex parte nostrōs premī intellēxerant, hìs auxiliō ex ulteriōribus castellīs dēductōs submittēbant.

TIE GAULS, HAVING TIICE TRIEI TO FORCE TIIE WORKS, RETIRE

82. I um longius à mūnītiōne aberant Gallī, plūs multitūdine tēlōrum prōficiēbant ${ }^{4}$; posteāquam ${ }^{5}$ propius successērunt, aut sē stimulīs ${ }^{6}$ inopinantēs induēbant aut in scrobīs dēlātī trānsfodiēbantur aut ex vāllō ac turribus trāiectì pīlīs mūrālibus ${ }^{\top}$ interībant. Multīs undique vulneribus acceptìs, nūllā mūnitiōne perruptā, cum lūx appeteret, ${ }^{8}$ veritī nē ab latere apertō ex superiōribus castrīs ēruptiōne circumvenīrentur, sē ad suōs recēpērunt. At interiōrēs dum ea quae ā Vercingetorīge ad ēruptiōnem praeparāta ${ }^{9}$ erant prōferunt, priōrēès

attribuō, 3, ūi, ūtus, assign

librile, is, throaving a stone a'eighing

a pound

sudis, is, f., stake

glāns, glandis, f., bullet

tenebrae, ārum, f., durkness

tormentum, ì, n., hurling machine

inopīnāns, inopinantis, unaware induō, 3, dūî, dūtus, impale

scrobis, is, m., pit

trānsfođīo, 3, fōdī, fossus, run through

träiciō, 3, iēcī, iectus, transfí.

intere $\overline{0}, 4$, īi, itum, perish

perrumpō, 3, rūpī, ruptus, brakk through

${ }^{1}$ prōterrent: prō, off. $\quad{ }^{2}$ prōspectū : compare with cōnspectus, noting the prefix. ${ }^{3}$ obvēnerant: composition? ${ }^{4}$ plūs prōficiēbant: the ${ }^{\prime}$ did more exccution. ${ }^{5}$ posteāquam: = postquam. "stimulis: Caesar describes these as "stakes a foot long with iron hooks on them." They were driven into the ground around and between pits. ${ }^{7}$ mūrālibus: mūrus + ālis, pertaining to. $\quad{ }^{8}$ appeteret: synonym of appropinquō. $\quad{ }^{9}$ praeparāta: composition?

Observe the many words in chapter $S_{\text {I }}$ referring to the equipment used by the Gauls and Romans in the assault. 
fossās explent, ${ }^{1}$ diūtius in hìs rēbus administrandīs morātī prius ${ }^{2}$ suōs discessisse cognōvērunt quam mūnītiōnibus appropinquārent. Ita rē infectā ${ }^{3}$ in oppidum revertērunt.

\section{SIXTY TIIOUSAND OF THE GAULS PREPARE TO ASSAULT TIIE UPPER CAMP}

83. Bis magnō cum dētrīmentōo repulsī Gallī quid agant cōnsulunt; locōrum ${ }^{*}$ perìtōs $^{5}$ adhibent, ex hīs superiōrum castrōrum sitūs mūnitiōnēsque cognōscunt. Erat ā septentriōnibus collis quem propter magnitūdinem circuitūs opere ${ }^{6}$ circumplectī nōn potuerant nostrī, necessāriōque paene inìquō̄ locō et lēniter dēclīvī castra fēcerant. Haec Gāius Antistius Rēgīnus et Gāius Canīnius Rebilus lēgātì cum duābus legiōnibus obtinēbant. Cognitīs per explōrātōrēes regiōnibus ducēs hostium sexāgintā mìlia ex omnī numèrō dēligunt, eārum cìvitātum quae maximam virtūtis opīniōnem habēbant; quid quōque ${ }^{8}$ pactō agī placeat occultē inter sē cōnstituunt; adeundī tempus dēfīniunt cum merīdiēs ${ }^{9}$ esse videātur. His cōpiīs Vercassivellaunum Arvernum, ūnum ex quattuor ducibus, propinquum Vercingetorīgis, praeficiunt. Ille ex castrīs prīmā vigiliā ēgressus prope cōnfectō sub lūcem ${ }^{10}$ itinere post montem sē occultāvit mìlitēsque ex nocturnō ${ }^{11}$ labōre sēsē reficere iussit. Cum iam merīdiēs appropinquāre vidērēetur, ad ea castra quae suprā dēmōnstrāvimus contendit; eōdemque tempore equitātus ad campestrīs mūnītiōnēs accēdere et reliquae cōpiae prō castrīs sēsē ostendere coepērunt.

situs, ūs, m., lecation

circumplector, 3. plexus, encirtle

lēniter, moderatily

dēclivis, e, s'étp

pactum, $\overline{1}, n .$. manner

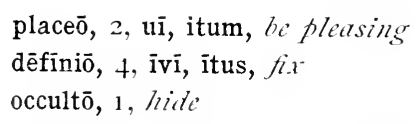

\footnotetext{
1 explent: compare compleō, noting the prefix. $\quad 2$ prius: take with quam. 3 infectā: in + faciō. Compare English "done," "undone." ${ }^{4}$ locōrum : limits perītōs. $\quad{ }^{5}$ peritōs: understand eōs. $\quad{ }^{6}$ opere: i.e. the fortifications. ${ }^{\top}$ inīquō: in + aequus. $\quad{ }^{8}$ quōque: not from quisque. ${ }^{9}$ merĩdiēs : medius + diēs. $\quad{ }^{\prime \prime}$ sub lūcem: about daz'n. ${ }^{11}$ nocturnō: nox + urnus, a time suffix.
} 
THE GAULS SALLY FORTI FROM ALESIA AND UNITE WITH THEIR FORCES OUTSIDE IN AN ATTACK ON THE ROMANS

84. Vercingetorīx ex arce Alesiae suōs cōnspicātus ex oppidō ēgreditur ; crātīs, longuriōs, mūrālīs ${ }^{1}$ falcìs, reliquaeque quae ēruptiōnis causā parāverat prōfert." Pugnātur ūnō tempore omnibus locīs atque omnia temptantur; quae minimē vīsa pars fïrma est, hūc concurritur. Rōmānōrum manus tantis mūnìtiōnibus distinētur ${ }^{3}$ nec facile plüribus locīs occurrit. Multum ad terrendōs ${ }^{4}$ nostrōs valet clāmor quī post tergum pugnantibus exsistit, quod suum perīculum in aliēnā vident virtūte cōnstāre; omnia enim plērumque quae absunt vehementius hominum mentīs perturbant.

THE GAULS MAKE A DESPERATE EFFORT TO FORCE THE ROMAN LINES

85. Caesar idōneum locum nactus quid quāque in parte gerātur cognōscit, ${ }^{5}$ labōrantibus subsidium submittit. Utrīsque ${ }^{6}$ ad animum occurrit ūnum esse illud tempus quo $\bar{o}^{\top}$ maximē contendī conveniat ${ }^{8}$ : Gallī, nisi perfrēgerint mūnītiōnēs, dē omnī salūte dēspērant ${ }^{9}$; Rōmāhī, sĩ rem obtinuerint, fīnem labōrum omnium exspectant. Maximē ad ${ }^{10}$ superiōrēs mūnitiōnēs labōrātur, ${ }^{11}$ quō Vercassivellaunum missum dēmōnstrāvimus. Inīquum ${ }^{12}$ locì ad dēclīvitātem ${ }^{13}$ fastīgium magnum habet mōmentum. Alī̄ tēla coniciunt, alì̄

arx, arcis, f., citadel

crātēs, ium, f., wickerwork

longurius, longu'rī, m., long pole

falx, falcis, f., hook

exsistō, 3, stitī, __, arise vehementer, furiously perfringō, 3, frēgīi, frāctus, break through

fastīgium, fastīgī, n., slope mōmentum, ì, n., importance

1 mūrāliss : mūrus + ālis. $\quad 2$ prōfert: composition? ${ }^{3}$ distinētur : dis + teneō. $\quad{ }^{4}$ terrendōs : compare with perterreō. ${ }^{5}$ cognōscit: understand et connecting this word with submittit. ${ }^{6}$ utrisque: dative of reference; of both parties. ${ }^{7}$ quōo : expresses time when. ${ }^{8}$ conveniat: it is fitting. 9 dēspērant: composition? ${ }^{1)}$ ad: necar. ${ }^{11}$ labōrātur: impersonal. 12 iniquum: composition? ${ }^{13}$ ad dēclivitātem: docimaìnt. 
testūdine factā subeunt; dēfatīgātīs invicem integrī succēdunt. Agger ab ūniversīs in mūnitiōnem coniectus et ascēnsum ${ }^{1}$ dat Gallīs et ea quae in terrā occultāverant Rōmānī contegit; nec iam arma nostrīs nec vīrēs suppetunt.

THE GAULS, REPULSED, ATTACK ANOTHER PART OF THE WORKS

86. His rēbus cognitīs Caesar Labiēnum cum cohortibus sex subsidiō $^{2}$ labōrantibus mittit. Imperat, sī sustinēre nōn possit, dēductīs cohortibus ēruptiōne ${ }^{3}$ pugnet; id, nisi necessāriō, nē faciat. Ipse adit reliquōs, cohortātur nē labōrī succumbant; omnium superiōrum dīmicātiōnum ${ }^{4}$ frūctum in eō diē atque hōrā docet cōnsistere. Interiōrēe ${ }^{5}$ dēspērātīs campestribus locīs propter magnitūdinem mūnītiōnum loca praerupta ascēnsu ${ }^{6}$ temptant; hūc ea quae parāverant cōnferunt. Multitūdine tēlōrum ex turribus prōpugnantīs dēturbant, aggere et crātibus fossās explent, ${ }^{7}$ falcibus vāllum ac lōrìcam rescindunt.

\section{C.ISAR DRIVES BACK THE GAULS ANI GOES TO THE IIELP OF LABIENUS}

87. Mittit prīmum Brūtum adulēscentem cum cohortibus Caesar, post cum aliis Gãium Fabium lẹgātum; postrēmō ipse, cum vehementius pugnārētur, integrōs subsidiō addūcit. Restitūtō proeliō

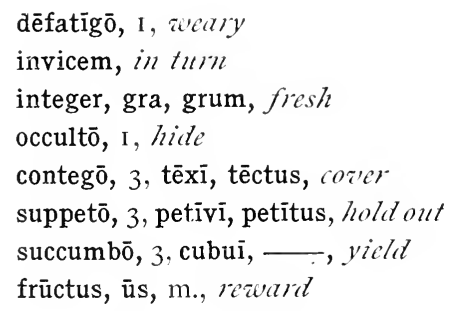

${ }^{1}$ ascēnsum: noun from ascendō. ${ }^{2}$ subsidiō: expresses purpose. 3 ēruptiōne: expresses manner. ${ }^{4}$ dìmicātiōnum: derivation? ${ }_{5}^{5}$ interiōrēs: understand ī. ${ }^{6}$ ascēnsū : with praerupta. ${ }^{7}$ explent: compare with compleō. 
ac repulsīs hostibus eō quō Labiēnum mīserat contendit; cohortīs quattuor ex proximō castellō dēdūcit, equitum partem sē sequī, partem circumīre exteriōrēs mūnìtiōnēs et à tergō hostīs adorīrī iubet. Labiēnus, postquam neque aggerēs neque fossae vim hostium sustinēre poterant, coāctīs ūndecim cohortibus, quās ex proximīs praesidī̄s dēductās fors obtulit, ${ }^{1}$ Caesarem per nūntiōs facit certiōrem quid faciendum existimet. Accelerat ${ }^{2}$ Caesar, ut proeliō intersit.

TIIE GALLIC FORCES OUTSIDE ARE DEFEATED, AND THOSE WITHIN ALESIA LOSE HOPE

88. Eius adventū ex colōre vestītūs cognitō, turmīsque equitum et cohortibus vīsīs quās sē sequī iusserat, ut dē locīs superiōribus haec $^{3}$ dēclīvia et dēvexa cernēbantur, hostēs proelium committunt. Utrimque clāmōre sublātō excipit rūrsus ex vāllō atque omnibus mūnìtiōnibus clāmor. Nostrī ēmissīs ${ }^{4}$ pìlīs gladiìs ${ }^{5}$ rem gerunt. Repente $^{6}$ post tergum equitātus cernitur; cohortēs aliae appropinquant. Hostēs terga vertunt; fugientibus equitēs occurrunt. Fit magna caedēs. Sedulius, dux et prīnceps Lemovīcum, occīditur; Vercassivellaunus Arvernus vīvus in fugā comprehenditur; signa mìlitāria septuāgintā quattuor ad Caesarem referuntur; paucì ex tantō numerō sē incolumēes in castra recipiunt. Cōnspicātī ex oppidō caedem et fugam suōrum dēspērātā salūte cōpiās à mūnitiōnibus redūcunt. Fit ${ }^{\overline{1}}$ prōtinus ${ }^{8}$ hāe rē auditā ex castrīs Gallōrum fuga.

fors, fortis, f., chance

vestitus, ūs, m., clothing, robe

turma, ae, f., troop

dēclivis, e, sloping

dēvexus, a, um, stèt caedēs, is, f., slaughter.

vivus, a, um, lizing

comprehendō, 3 , hendī, hēnsus, seize

1 obtulit: composition? 2 accelerat: ad + celerō; compare the adjective celer. ${ }^{3}$ haec: i.e. places. ${ }^{4}$ èmissĩs: synonym of iaciō. ${ }^{5}$ gladiis : states the means of gerunt. ${ }^{6}$ repente: synonym of subitō. ${ }^{7}$ fit, etc.: observe the inversion of the usual order of words. " prōtinus: synonym of statim and continuō. 
Quod $^{1}$ nisi crēbrīs subsidīs ac tōtīus diēî labōre mìlitēs essent dēfessī, omnēs hostium cōpiae dēlērī potuissent. Dē mediā nocte missus equitātus novissimum agmen cōnsequitur ; magnus numerus capitur atque interficitur, reliquī ex fugā in civvitātēs discēdunt.

\section{THE NEXT DAY AFTER A COUNCIL IN THE TOWN VERCINGETORIX SURRENDERS WITH THE OTHER GALLIC CHIEFS}

89. Posterō diē Vercingetorìx conciliō convocātō id bellum sē suscēpisse nōn suārum necessitātum, ${ }^{2}$ sed commūnis lỉbertātis causā dēmōnstrat ; et quoniam sit fortūnae cēdendum, ${ }^{3}$ ad utramque rem sē illīs offerre, seu morte suā Rōmānīs satisfacere seu vīvum trādere velint. Mittuntur ${ }^{4}$ dē hīs rēbus ad Caesarem lēgātī. Iubet arma trādì, prīncipès prōdūcī. Ipse in mūnītiōne prō castrīs cōnsīdit; eō ducēs prōdūcuntur. Vercingetorīx dēditur, arma proiciuntur. Reservātīs Aeduīs atque Arvernīs, sī per eōs cīvitātēs recuperāre posset, ex reliquīs captìvìs tōtī exercituī capita singula praedae nömine distribuit.

\section{CASAR RESTORES PEACE IN GAUL AND DISTRIBUTES HIS FORCES THROUGHOUT THE COUNTRY}

90. Hīs rēbus cōnfectīs in Aeduōs proficīscitur; cīvitātem recipit. Eō lēgātī ab Arvernīs missī quae imperāret sē factūrōs pollicentur. Imperat magnum numerum obsidum. Legiōnēs in hīberna mittit.

$$
\begin{aligned}
& \text { dēleō, 2. lēvī, lētus, destroy } \\
& \text { vìvus, a, um, lizing }
\end{aligned}
$$$$
\text { recuperō, } 1 \text {, recover }
$$

1 quod: so that (literally, as to which).

2 necessitātum: English derivative? $\quad{ }^{3}$ cẽdendum: impersonal. ${ }^{4}$ mittuntur, etc.: observe the inversion of the usual order of words.

Plutarch says that Vercingetorix put on his finest armor and upon his war horse came forth from the town. After riding around Cæsar several times as he sat in his tribunal, he dismounted, took off his armor, and seated himself at Cæsar's feet. He sat there in silence till Cæsar ordered him to be removed and kept for his triumph in Rome. There he was led in the triumphal procession and afterwards put to death in prison. 
Captīvōrum circiter vīgintī mīlia Aeduīs Arvernīsque reddit. Titum Labiēnum cum duābus legiōnibus et equitātū in Sēquanōs proficīscì iubet; huic Mārcum Semprōnium Rutilum attribuit. Gāium Fabium lēgātum et Lūcium Minucium Basilum cum legiōnibus duābus in Rēmīs collocat, nē quam à fīnitimīs Bellovacīs calamitātem accipiant. Gāium Antistium Rēgīnum in Ambivaretōs, Titum Sextium in Biturīgēs, Gāium Caninium Rebilum in Rutēnōs cum singulīs legiōnibus mittit. Quīntum Tullium Cicerōnem et Pūblium Sulpicium Cavillōnī ${ }^{1}$ et Matiscōne ${ }^{1}$ in Aedūs ad Ararim reī frūmentāriae causā collocat. Ipse Bibracte hiemāre cōnstituit. Hìs rēbus ex Caesaris litterīs cognitīs Rōmae diērum vīgintī supplicātiō redditur.

attribuō, 3, ūi, ùtus, assign supplicātiō, ōnis, f., thanksgizing

${ }^{1}$ Cavillōni, Matiscōne: Cavillonum and Matisco, towns of the Aedui. 
ANNOUNCEMENTS 


\section{TWO LATIN PLAYS}

By Susan Paxson, Teacher of Latin and German, High School, Omaha, Nebr.

I $2 \mathrm{mo}$, cloth, $\mathrm{xii}+39$ pages, 45 cents

$\boldsymbol{C}$ "A Roman School" and "A Roman Wedding" are the only dramatizations in Latin which are in any way suitable for reproduction in the high schools. They were written by the author for the purpose of creating a new interest in the study of the classics among secondary pupils, and, as given already in several schools, have proved an effective stimulus to the class work.

d The plays give in turn a picture of school life in the days of Cæsar and Cicero, and again, of a high-class Roman wedding in the same period.

$\boldsymbol{\mathbb { C }}$ The greatest care has been taken to make the detail authentic and the descriptions true to life. The diction is accurately classic, and there is plenty of humor and action.

$\boldsymbol{\mathbb { C }}$ As a means of producing a genuine appreciation of Roman life and customs, and of making real the character of Latin literature, the book has unusual educational value.

\section{RECENT LATIN BOOKS}

\section{LATIN FOR BEGINNERS}

By Benjamin L. D'Ooge, Professor of Latin in Michigan State Normal College. I 2 mo, cloth, $34^{8}$ pages, illustrated, with four colored plates and map in color, $\$ 1.50$.

\section{ESSENTIALS OF LATIN SYNTAX}

By Charles Christopher Mlerow, Instructor in Classics in Princeton University. $12 \mathrm{mo}$, cloth, $9^{8}$ pages, 90 cents.

\section{LIVE ISSUES IN CLASSICAL STUDY}

By Kart. Pomeroy Harrington, Professor of the Latin Language and Literature in Wesleyan University, Middletown, Conn. $12 \mathrm{mo}$, cloth, 76 pages, 75 cents. 


\title{
D'OOGE'S LATIN COMPOSITIONS
}

\author{
By Benjamin L. D'Ooge
}

Professor of Latin in the Michigan State Normal School, Ypsilanti

\section{LATiN COMPOSITION FOR SECONDARY SCHOOLS}

\author{
r mo, cloth, $\mathrm{r} 3 \mathrm{r}+\mathrm{rgo}$ pages, $\$ \mathrm{r} .00$
}

Part I, based on Cisar's “Gallic War." ramo, cloth, xii + iz r pages, 5o cents PARTs II ANd III, Based ON "Cicero." r2mo, cloth, rgo pages, 6o cents

PART I comprises the first volume and is to be used in connection with the first four books of "Cæesar" during the second year.

Parts II and III form the second volume. Part II, intended to accompany the work of the third year, is based on Cicero's "Manilian Law," "Catiline," I-IV, and the "Archias." Part III, designed for a review of syntax in the fourth year, consists of thirty-five lessons of miscellaneous sentences based on "Cæsar" and "Cicero," and is accompanied by a special Vocabulary.

\section{LATin Composition to accompany GREENOUGH, D'OOGE, AND DANIELL'S SECOND YEAR LATIN r $2 \mathrm{mo}$, cloth, $x+$ r 3 I pages, 50 cents}

THIs book has been especially prepared for schools using Greenough, D'Ooge, and Daniell's "Second Year Latin." With the second volume of D'Ooge's "Latin Composition for Secondary Schools" it forms a complete course for schools that precede their work in "Cicero" with "Second Year Latin" rather than with the first four books of "Cæsar."

\section{LATIN Composition TABLET}

svo tablet, 6o pages, 15 cents

THIs composition tablet includes a system of signs for the correction of exercises. The plan lessens the labor of the teacher and gives the pupil an opportunity for more than the usual amount of Latin writing. 

Date Due

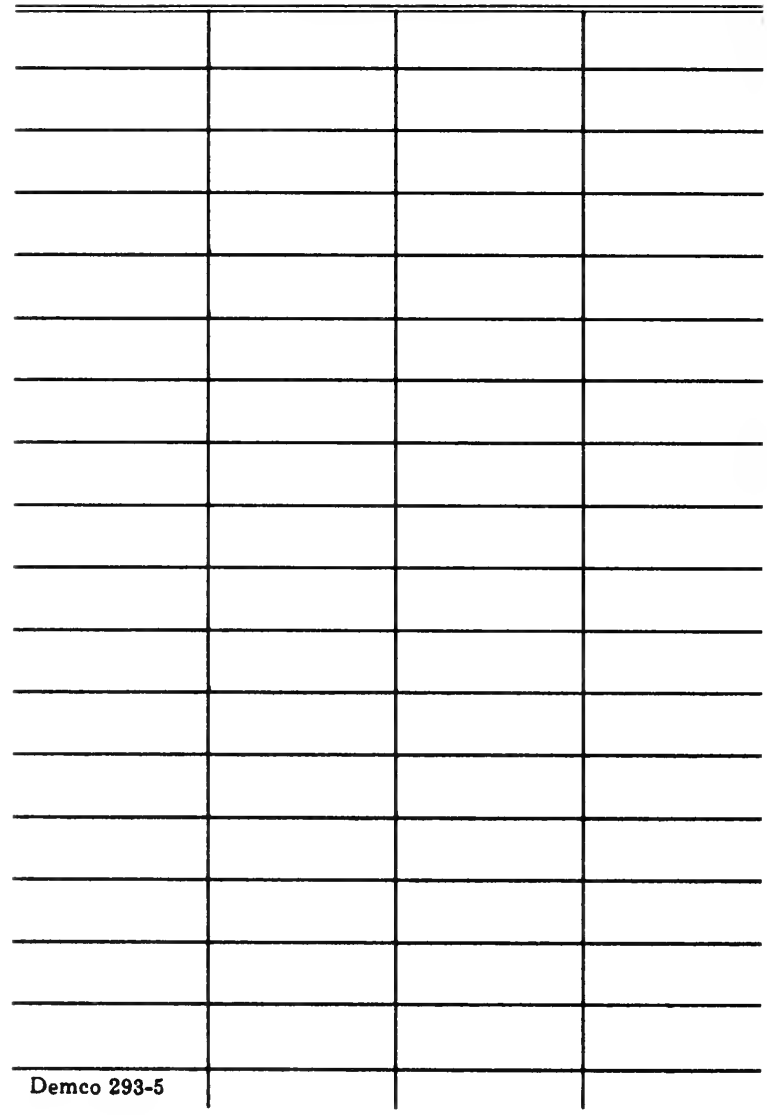




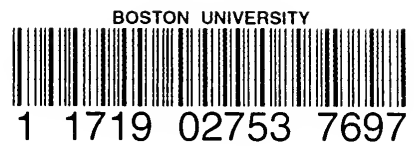


mym 3Im)

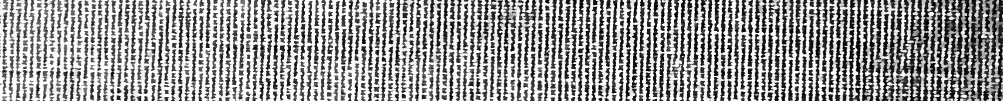

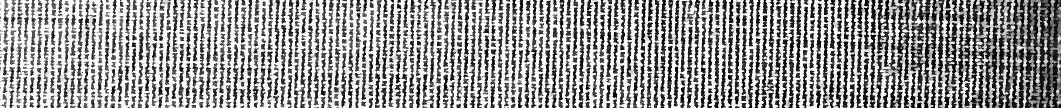

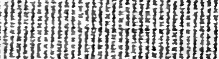

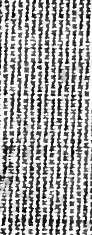

